\begin{abstract}
UNIVERSIDADE DE SÃO PAULO
FACULDADE DE FILOSOFIA, LETRAS E CIÊNCIAS HUMANAS

DEPARTAMENTO DE GEOGRAFIA

PROGRAMA DE PÓS-GRADUAÇÃO EM GEOGRAFIA HUMANA
\end{abstract}

AS GEOTECNOLOGIAS COMO INSTRUMENTO DE GESTÃO

TERRITORIAL INTEGRADA E PARTICIPATIVA

VANESSA GARCIA FAVRIN

SÃO PAULO

2009 


\author{
UNIVERSIDADE DE SÃO PAULO \\ FACULDADE DE FILOSOFIA, LETRAS E CIÊNCIAS HUMANAS \\ DEPARTAMENTO DE GEOGRAFIA \\ PROGRAMA DE PÓS-GRADUAÇÃO EM GEOGRAFIA HUMANA
}

\title{
AS GEOTECNOLOGIAS COMO INSTRUMENTO DE GESTÃO TERRITORIAL INTEGRADA E PARTICIPATIVA
}

VANESSA GARCIA FAVRIN

Dissertação apresentada ao Programa de Pós-
Graduação em Geografia Humana do
Departamento de Geografia da Faculdade de
Filosofia, Letras e Ciências Humanas da
Universidade de São Paulo, para obtenção do
título de Mestre em Geografia.

Orientador: Prof. Dr. Reinaldo Paul Pérez Machado

SÃO PAULO

2009 
DEDICATÓRIA

À toda minha família, tão importante para mim. 


\section{AGRADECIMENTOS}

Às sábias contribuições do Prof. Dr. Reinaldo Paul Pérez Machado, pela orientação e apoio.

Aos técnicos dos municípios que responderam gentilmente aos questionários e fizeram valiosas observações.

Aos amigos que pude conviver durante as aulas deste curso.

Em especial a minha mãe e meu marido pelo apoio, compreensão e paciência que foram tão importantes para que eu chegasse até aqui.

Aos meus queridos Vitor e Giovanna que cresceram tanto, nesse período do mestrado e que entenderam a importância desse trabalho. 


\section{RESUMO}

O presente trabalho apresenta formas contemporâneas da administração pública lidar com seu usuário final: os cidadãos. Discute o que existe de mais moderno em tecnologias de informação e comunicação para melhorar as condições de governabilidade, controle do território, aplicações de políticas de segurança, educação, saúde, habitação, etc. Esse tema é atualmente muito discutido no mundo e nesta pesquisa pretende-se incorporar à discussão os benefícios das Geotecnologias potencializando o governo.

É perceptível que há um consenso sobre novos paradigmas na gestão pública neste início de milênio. Encontros mundiais, fóruns, elaboração de Agendas de Meio Ambiente, Habitação, etc. falam sobre os mesmos conceitos: gestão, planejamento estratégico, desenvolvimento sustentável, cidade sustentável, desenvolvimento local, participação e representação popular.

Com o incremento do Geoprocessamento na gestão pública, os benefícios do gerenciamento de todas as áreas do município possibilitam um amplo e real diagnóstico da cidade, serve tanto no apoio às políticas públicas como na democratização da informação.

A prestação de serviços de governo com apoio das tecnologias de informação e comunicação e a presença do governo-eletrônico é um processo que só avança e melhora, como uma empresa vai aperfeiçoando seu site, tornando-o mais dinâmico, mais completo, o governo nas suas diversas esferas vai ampliando cada vez mais suas interfaces com os cidadãos. Pode-se sentir isso à medida que mais procedimentos se tornam disponíveis no meio eletrônico, possibilitando que uma pessoa ou empresa tenha informações on line.

A pesquisa mostrou que as inúmeras inovações tecnológicas estão de fato contribuindo para a melhora das gestões municipais, porém, poderiam melhorar ainda mais se existisse um direcionamento do Governo Federal para tal. A visualização do território com o geoprocessamento não é a solução mágica para os problemas das cidades, nem pretende substituir a sensibilidade dos técnicos, mas o diálogo travado através destas inovações é único e aponta para um futuro com maior participação popular.

Palavras chaves: geotecnologias - governo eletrônico - participação popular - gestão - análise espacial 


\begin{abstract}
This work presents contemporary forms of public administration to deal with your final user: the citizens. It argues what it exists of more modern in technologies of information and communication to improve the conditions to govern, control of territory, applications of security politics, education, health, housing etc. This subject is currently very argued in the world and in this research the intention is incorporate to the argumentation the benefits of the Geotechnologies powering the government.

It can be perceived that there is a consensus on new paradigms in public administration in the beginning of this millennium. Global meetings, forums, elaboration of agendas for the Environment, housing, etc. speak on the same concepts: management, strategical planning, sustainable development, sustainable city, local development, popular participation and representation.

With the increment of Geoprocessing in public administration, the benefits of the management of all areas in the county allow a comprehensive and real diagnosis of the city, serving both in supporting public politics and in the democratization of the information.

The government services with support of information and communication technologies and the presence of electronic-government it is a process that moves forward and it gets on as a company goes improving its site, becoming it more dynamic, more comprehensive, the government also in its diverse spheres goes extending more each time its interfaces with the citizens. This can be felt, as more procedures become available in electronic means what make possible a person or company has information online.

The research showed that many technological innovations are in fact contributing to the improvement of municipal management, however, they could improve still more if there was a aim of the Federal Government for such. The view of the territory with the Geoprocessing is not a magical solution for the problems of the cities, nor intends to substitute the sensitivity of the technicians, but the dialogue through these innovations is singular and points to a future with bigger popular participation.
\end{abstract}

Keywords: geotechnologies - electronic-government - popular participation management - spatial analisys 
SUMÁRIO

LISTA DE FIGURAS E MAPAS 010

LISTA DE TABELAS E QUADROS 011

1. INTRODUÇÃO 013

1.1. ESTRUTURA DO TRABALHO 013

1.2. CONSIDERAÇÕES INICIAIS 013

1.3. OBJETIVOS DA PESQUISA 015

1.4. JUSTIFICATIVA E PLANO GERAL 016

2. CONCEITOS DE GEOTECNOLOGIAS 019

2.1. INTRODUÇÃO 019

2.2. GEOPROCESSAMENTO E SISTEMAS DE INFORMAÇÕES

2.2.1. Geoprocessamento no Brasil 021

2.2.2. Popularização do Geoprocessamento 022

2.3. SISTEMA DE POSICIONAMENTO GLOBAL - GPS 023

2.3.1. Aplicações 024

2.4. SENSORIAMENTO REMOTO 025

2.4.1. Princípios Básicos 025

2.5. ANÁLISE ESPACIAL 026

2.5.1. Tipos de Dados de Análise Espacial 027

2.5.2. A Captura de Dados para SIG 028

2.5.3. Dependência Espacial 029

2.5.4. Inferência Estatística para Dados Espaciais $\quad 030$

2.5.5. Estacionariedade e Isotropia 030

2.5.6. O Processo de Análise Espacial 031

3. GOVERNO ELETRÔNICO 035

3.1. INTRODUÇÃO 035

3.1.1. Conceitos 035

3.1.2. Os Estágios de Informatização dos Governos 035

3.1.3. Tipos de Governo 036

3.1.4. Fases de Desenvolvimento do Governo Eletrônico $\quad 039$

3.2. ESTRATÉGIAS DE GOVERNO ELETRÔNICO 043

3.2.1. Marco Inicial 043

3.2.2. As Diretrizes do Governo Eletrônico no Brasil 044

3.2.3. Os Pré-requisitos do Governo Eletrônico 047

3.2.4. A Implantação de um Governo Eletrônico Nacional $\quad 049$

3.2.5. A Importância das Agências de Sociabilização da Informação - ASI no Brasil 051

3.3. O GOVERNO ELETRÔNICO NO MUNDO 056

3.3.1. O Governo Eletrônico na América Latina 061 
3.3.2. Destaque de Casos de Sucesso no Mundo

4. O SISTEMA DE INFORMAÇÃO GEOGRÁFICA NO GOVERNO ELETRÔNICO

070

070

071

073

074

075

076

077

079

4.2.2. Possibilidades de Aplicações

4.2.3. Projeção dos Resultados previstos com o SIG no Governo Eletrônico

086

089

089

092

093

096

096

096

097

5.2.1. A Cidade Sustentável

099 e o Desenvolvimento Sustentável

5.2.3. A Importância do Agir Local para Influenciar Globalmente

100

102

102

103

104

106

107

108

109

110

5.4.3. Participação e Representação Popular

5.4.4. A Experiência da Participação Popular na Cidade de São Bernardo do Campo

112 
$\begin{array}{ll}\text { 7. ANÁLISE DE MUNICÍPIOS } & 127\end{array}$

7.1. INTRODUÇÃO

7.2. RESULTAD̉OS E DISCUSSÃO

7.2.1. Órgãos nacionais 127

7.2.2. Municípios 129

7.2.3. Portais Internacionais SIG na Internet 153

$\begin{array}{ll}\text { CONSIDERAÇÕES FINAIS } & 168\end{array}$

$\begin{array}{ll}\text { REFERÊNCIAS } & 175\end{array}$

$\begin{array}{ll}\text { ANEXOS } & 179\end{array}$ 


\section{LISTA DE FIGURAS E MAPAS}

$\begin{array}{lr}\text { Figura } 01 \text { - Esquema Metodológico } & 121\end{array}$

Figura 02 - Site da Pref. de São Paulo - Link para o Geo 134

Figura 03 - Site da Pref. de São Paulo - SIG HABISP 135

$\begin{array}{ll}\text { Figura } 04 \text { - Portal Geo do Rio de Janeiro } & 136\end{array}$

$\begin{array}{ll}\text { Figura } 05 \text { - Site da Pref. de Santos - SIG Santos } & 137\end{array}$

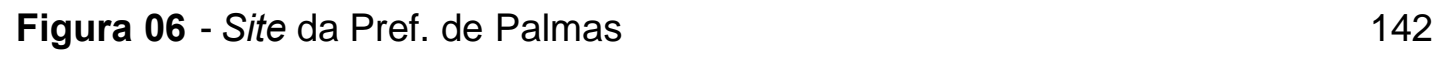

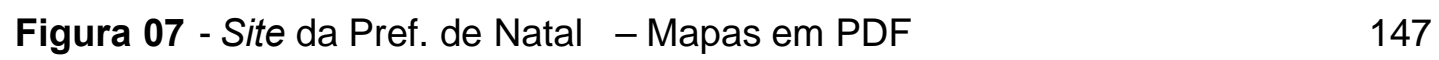

$\begin{array}{ll}\text { Figura } 08 \text { - Site da Pref. de Florianópolis - GeoFloripa } & 149\end{array}$

Figura 09 - Explicação sobre o software GeoFloripa 150

Figura 10 - Site da Pref. de Porto Alegre - Link para Mapa da Cidade 151

Figura 11 - Site oficial da cidade de NY - Link para o geo 157

$\begin{array}{ll}\text { Figura } 12 \text { - Mapa do SIG Lisboa } & 158\end{array}$

$\begin{array}{ll}\text { Figura } 13 \text { - Mapa de Pequim disponível no site municipal } & 159\end{array}$

Figura 14 - Link de Acesso à Part. Pop. disponível no site de Roma 160 


\section{LISTA DE QUADROS}

Quadro 01 - Site da Secretaria da Fazenda do Estado de São Paulo 41

Quadro 02 - Site da Receita Federal - Brasil 41

Quadro 03 - Site do Governo do Estado do Texas - EUA 41

Quadro 04 - Conselhos ou Comitês Nacionais de

Desenvolvimento do Governo Eletrônico na América Latina 50

Quadro 05 - Agências Estaduais de Socialização da Informação - ASIs 51

Quadro 06 - Site da PRODERJ - Gov. do Estado do Rio de Janeiro 53

Quadro 07 - Site da PRODAM - Pref. do Município de São Paulo 54

Quadro 08 - Posição Mundial de Desenvolvimento de Governo

Eletrônico entre Países do 1ำ ao 35은 lugar 57

Quadro 09 - Posição Mundial de Desenvolvimento de Governo

Eletrônico entre Países do 36음 70ํlugar 58

Quadro 10 - Posição Mundial de Desenvolvimento de Governo
Eletrônico por Regiões

Quadro 11 - Posição Mundial de Desenvolvimento de Governo
Eletrônico na América do Sul

Quadro 12 - Site do Governo de Singapura $\quad 65$

Quadro 13 - Site do Governo da Coréia 66

Quadro 14 - Site do Governo do Canadá $\quad 67$

Quadro 15 - Site do Governo do Estado de São Paulo 68

Quadro 16 - Site do Governo do Chile $\quad 71$

Quadro 17 - Site da Receita Federal - Brasil 72

Quadro 18 - Dimensão, Foco e Conteúdo dos Sites 73

Quadro 19 - Níveis de Participação Cidadã $\quad 75$

Quadro 20 - Classificação de Estágios de Desenvolvimento

Quadro 21 - Site do Cartão Cidadão - Governo de Portugal 81

Quadro 22 - Site do Governo do Estado de Alagoas 84

Quadro 23 - Entrevista sobre os usos futuros do SIG 86

$\begin{array}{cc}\text { Quadro } 24 \text { - Questionário - modelo } 01 \text { - Enviado às Agências } & \\ \text { de Socialização da Informação - ASls } & 116\end{array}$

Quadro 25 - Questionário - modelo 02 - Enviado ao IBGE e INPE 117

$\begin{array}{cc}\text { Quadro } 26 \text { - Questionário - modelo } 03 \text { - Enviado ao } & 117 \\ \text { Ministério das Cidades } & 117\end{array}$

Quadro 27 - Questionário - modelo 04 - Enviado ao Comitê Executivo de Governo Eletrônico - CEGE do Ministério do Planejamento

Quadro 28 - Questionário - modelo 05 - Enviado à Divisão de Cartografia - DICAR do Ministério da Defesa 119

Quadro 29 - Questionário - modelo 06 - Enviado aos Municípios 120

Quadro 30 - Modelo - Comparação sobre o direcionamento ou gerenciamento de Sistemas de Informações Geográficas nos Governos Estaduais

Quadro 31 - Modelo - Itens para Avaliação dos Projetos de SIGs Municipais

Quadro 32 - Modelo - Itens de Avaliação de SIGs em Portais Municipais 125

Quadro 33 - Antecedentes Metodológicos do Desenvolvimento de SIGs Municipais 
Quadro 34 - Comparação sobre o direcionamento ou gerenciamento de Sistemas de Informações Geográficas nos Governos Estaduais

Quadro 35 - Itens para Avaliação dos Projetos de SIGs Municipais na Região Sudeste - Capitais Estaduais

Quadro 36 - Itens para Avaliação dos Projetos de SIGs Municipais na Região Sudeste - Outras Cidades

130

Quadro 37 - Site do Município de São Paulo - Link para Mapas e Dados

Quadro 38 - Itens para Avaliação dos Projetos de SIGs Municipais na Região Centro Oeste - Capitais Estaduais

Quadro 39 - Itens para Avaliação dos Projetos de SIGs Municipais na Região Norte - Capitais Estaduais

Quadro 40 - Itens para Avaliação dos Projetos de SIGs Municipais na Região Nordeste - Capitais Estaduais - parte 1

Quadro 41 - Itens para Avaliação dos Projetos de SIGs Municipais na Região Centro Oeste - Capitais Estaduais - parte 2

Quadro 42 - Site da Prefeitura de João Pessoa 146

Quadro 43 - Site da Prefeitura de Natal

Quadro 44 - Itens para Avaliação dos Projetos de SIGs Municipais na Região Sul - Capitais Estaduais

Quadro 45 - Itens de Avaliação de SIGs em Portais Municipais - Nacionais

Quadro 46 - Histórico do SIG do Estado de Nova lorque 153

Quadro 47 - Itens de Avaliação de SIGs em Portais - Internacionais 156

Quadro 48 - Novas Evoluções do SIG - Londres 3-D 


\section{INTRODUÇÃO}

\subsection{ESTRUTURA DO TRABALHO}

O presente trabalho encontra-se organizado em 7 Capítulos. No Capítulo 1 Introdução, explana-se a idéia central e seus alcances, bem como seus objetivos. No Capítulo 2, faz-se uma revisão da literatura no que diz respeito às Geotecnologias. $O$ Capítulo 3 apresenta os principais conceitos sobre Governo Eletrônico, trazendo à discussão as novas formas de Governo, em seguida no Capítulo 4, o Sistema de Informação Geográfica como potencializador do Governo Eletrônico é o principal foco do trabalho. Para encerrar a parte teórica, no Capítulo 5, discute-se as idéias mais recentes em planejamento urbano. A trajetória metodológica é descrita no Capítulo 6 , explicando os critérios utilizados para a escolha dos municípios e os instrumentos de coleta de dados. No Capítulo 7 analisa-se os casos selecionados e por fim as Considerações Finais e Referências Bibliográficas.

\subsection{CONSIDERAÇÕES INICIAIS}

Para administradores municipais e técnicos em planejamento urbano, a tecnologia do Geoprocessamento torna-se imprescindível como instrumento de leitura das cidades, dando suporte a processos de análise espacial e suas aplicações no espaço intra-urbano contemporâneo, considerando a complexidade que o define.

A idéia de que toda ação, movimentação ou dado está vinculado a uma localização geográfica, encaixa-se perfeitamente com as ações públicas municipais que ocorrem num território, pois um município não sendo uma abstração jurídica, como são os Estados e a União, possui um território e pelo qual é responsável por sua administração.

Em planejamento urbano, necessita-se da análise espacial para subsidiar a tomada de decisão, para a intervenção no espaço urbano, ou na definição de políticas que regulam o uso e a ocupação deste espaço. Devido a sua facilidade em análise, visualização e integração de dados, o Sistema de Informações Geográficas (SIG) torna-se perfeito para tal.

Fica impossível imaginar o futuro das políticas públicas sem a aplicação de técnicas modernas de planejamento e, cada vez mais, as geotecnologias estão sendo utilizadas por profissionais que lidam com a cidade, principalmente por causa da evolução tecnológica da década de 90 , que trouxe uma maior disseminação de conceitos e aplicações, além da melhoria de softwares. Porém, ainda em escala muito 
insignificante, comparando-se com as infinitas possibilidades de uso que podem ser proporcionadas por esta tecnologia.

A cidade é formada pelo ambiente natural e construído, com traçado viário, construções, equipamentos, áreas livres e principalmente pessoas. São seus cidadãos que circulam, interagem e se utilizam de seus itens, portanto é muito importante que um projeto de SIG seja desenvolvido até que o usuário final seja a população. A democratização da informação e a transparência das ações, melhora os serviços públicos oferecidos e por consequência a vida urbana.

O objetivo macro a ser atingido é apresentar os conceitos e as formas de aplicações do Geoprocessamento no ambiente urbano, discutindo experiências concretas de casos de alguns municípios que avançaram na implantação do SIG e diagnosticar as inúmeras dificuldades enfrentadas pelas administrações públicas em utilizar por completo os benefícios dessa moderna tecnologia.

A cartografia e a análise geográfica não são procedimentos científicos novos no processo de tomada de decisões técnicas, no entanto o SIG possibilita de maneira rápida e segura as análises antes efetuadas manualmente, também permite a agregação de um grande número de informações, o que torna esses instrumentos imprescindíveis nos dias de hoje.

É importante destacar projetos que possibilitam não só implantação de um software SIG, mas que sejam capazes de realizar análise espacial, diagnósticos precisos com tomada de decisões, aplicações de políticas públicas que resultem em maior rapidez, maior abrangência de efeitos positivos e assim melhorias para os cidadãos.

Dos empecilhos da disseminação da tecnologia de geoprocessamento aplicado às administrações públicas municipais que se iniciaram na década de 90,0 principal problema enfrentado era o alto custo da implantação, somado à falta de treinamento adequado aos funcionários que iam utilizar o Sistema. A situação vem se modificando desde o início dos anos 2000 com diversos fatores que contribuem:

- Imagens de satélite e técnicas de sensoriamento remoto utilizadas com baixo custo para mapear o meio físico e gerar uma avaliação ambiental completa;

- Satélites de alta resolução, permitem produzir mosaicos digitais com imagens integrais do meio urbano e mapa preciso de quadras e vias com custo inferior a 50 \% a uma restituição convencional completa, além de vantagens na operação;

- Complementação aos aerolevantamentos e nos trabalhos de recadastramento em campo, utilizando GPS para obter informações geográficas precisas e a custo reduzido; 
- Criação de um banco de dados único, integrando todas as informações existentes às bases cartográficas, aplicativos de geoprocessamento customizados para cada necessidade administrativa, garantem facilidade de uso nos diversos departamentos municipais;

- O mapeamento e o mosaico digital avaliam o banco de dados existente da prefeitura e permite a concentração do recadastramento apenas para elementos discrepantes, resultando em economia e menor prazo para implantação do projeto;

- Implantação do SIG em etapas de modo a utilizar o geoprocessamento em rotinas simples no princípio para já gerar resultados, em vez de esperar todo o processo terminar;

- Uso de Internet e intranet permitem levar os benefícios da informatização para toda a máquina administrativa, bem como tornam públicas informações de interesse da sociedade;

- Redução de custos em todas as etapas de implantação do SIG e o resultado obtido na melhora das arrecadações torna o Geoprocessamento auto-financiável e compatível com o período de uma gestão de quatro anos.

\subsection{OBJETIVOS DA PESQUISA}

Os objetivos da pesquisa são:

\section{a) Mostrar como as Geotecnologias podem ser uma prática adotada para a melhora da qualidade de vida.}

A falta de informações gerais sobre o comportamento da cidade acarreta em distorções de investimento público e descontinuidade entre as administrações subsequentes, gerando grande prejuízo em obras desnecessárias e outras não concluídas.

Contudo, o crescente uso dessas tecnologias, principalmente através do governo -eletrônico e a presença do governo na web, entre outros meios, sinalizam que uma nova cultura está sendo incorporada no ambiente de centros de pesquisa urbana e órgãos governamentais, responsáveis pela gestão urbana: técnicas comumente usadas há décadas por urbanistas, em geral, podem agora ser processadas digitalmente, o que garante mais eficácia, mais rapidez, além de possibilitar a vantagem de trabalhar com grandes bases de dados e de poder considerar ao mesmo tempo um número muito maior de variáveis, ou seja, a complexidade da cidade contemporânea pode ser lida com maior precisão e pode ser apresentada à população de várias formas, facilitando a vida cotidiana. 
b) Responder a questão: Estamos atrasados em relação a outros países, ou todos caminham mais ou menos no mesmo estágio? Selecionar casos de alguns municípios para identificar aplicações práticas e problemas enfrentados, comparados com cidades de outros países;

Conforme a metodologia de pesquisa apresentada no Capítulo 6, selecionar e analisar os diferentes níveis de evolução em que se encontram algumas cidades, avaliando seus resultados, benefícios que trouxeram para o cidadão e para a administração, qual aplicação prática está sendo mais usada e que tipo de dificuldades encontram para implantação, manutenção e aproveitamento do processo.

c) Quais os problemas, etapas e desafios que temos que enfrentar para atingir uma melhora significativa na gestão pública e consequentemente na vida do cidadão, tendo como diretrizes o aumento da participação da população no governo, do agir local e da cidade sustentável.

\subsection{JUSTIFICATIVA E PLANO GERAL}

Com a utilização do SIG, uma administração pública pode, por exemplo, acompanhar o crescimento da cidade, ter a manutenção do cadastro imobiliário, controlar a atuação de distribuidoras de serviços, identificar áreas de inundação, ocorrência de criminalidade, otimizar o atendimento de emergências (bombeiros, ambulâncias e policiais), entre outras atividades.

Enfim, o geoprocessamento pode subsidiar a criação de bases e diretrizes às atividades e investimentos nas áreas tecnológicas e de recursos humanos, otimizar procedimentos técnico-administrativos, retratar a sociedade, suas prioridades, suas deficiências e as informações necessárias ao cidadão, possibilitando definições de políticas públicas em prol de uma sociedade mais justa.

Num país de dimensão continental como o Brasil, com uma grande carência de informações adequadas para a tomada de decisões sobre os problemas urbanos, rurais e ambientais, o Geoprocessamento apresenta um enorme potencial, principalmente se baseado em tecnologias de custo relativamente baixo, em que o conhecimento seja adquirido localmente.

A falta de investimento em técnicas modernas de planejamento urbano, a falta de dados técnicos atualizados, a priorização de investimentos em obras de aparência para fins políticos e a descontinuidade de programas técnicos quando há troca na administração pública, são algumas das dificuldades enfrentadas para a implantação do SIG. 
O atraso neste processo nos coloca mais uma vez em condição desfavorável para a diminuição dos problemas sócio-econômicos brasileiros.

Na década de 90 houve uma certa popularização dos softwares de SIG e atualmente são oferecidas funções de maneira tão simples que não é necessário ser um especialista em informática para usá-las.

Porém, o processo de informatização das prefeituras é recente, e vem caminhando paralelamente à introdução e ao desenvolvimento desta tecnologia no país. Esse fato reforça a necessidade de estudos na área para acompanhar e auxiliar os municípios no processo de informatização.

Alguns aspectos administrativos prejudicam a implantação do Geoprocessamento. São eles:

a) os administradores municipais têm conhecimento que os Sistemas de Informações Geográficas podem auxiliar no gerenciamento urbano, contudo as dúvidas relativas a todos aspectos desta técnica são limitações que impedem o bom desenvolvimento de um projeto adequado às realidades e necessidades de cada cidade;

b) os técnicos dos mais diversos níveis, de maneira geral, desconhecem o assunto porque não fez parte de sua formação profissional;

c) nas Prefeituras que optaram por estratégias de longo prazo, os resultados não são favoráveis, devido principalmente, às injunções políticas como mudanças de governo e ou prioridades governamentais;

d) alguns autores, alertam que são fatores determinantes para o sucesso de uma implementação de SIG o conhecimento da técnica, o treinamento, o planejamento, o plano de ação e a institucionalização. Pode-se considerar que o comprometimento do executivo é fundamental para o sucesso da implantação do sistema. E enfatiza-se que o sucesso de qualquer projeto depende do cumprimento do cronograma, dos custos, qualidade e equilíbrio financeiro.

e) a direção técnica na implantação de SIG efetivamente exige conhecimentos teóricos abrangentes e experiência dos seus responsáveis. As Prefeituras geralmente não contam com profissionais especializados para consultoria técnica, muitas percorrem longos caminhos de aprendizagem, pulverizam recursos financeiros, não possuem planejamento com definições claras de objetivos, metas e prazos, conduzindo certamente a resultados não satisfatórios;

f) as administrações municipais, diferentemente das empresas privadas, estão sujeitas a cenários políticos que geram instabilidades para implantação e 
continuidade de novas tecnologias. Para reverter esse quadro, é necessário que as Prefeituras desenvolvam um processo de aculturamento interno contínuo das novas tecnologias, colocando em prática aplicativos que facilitem as tarefas funcionais cotidianas, desde uma simples informação de localização de uma via pública, até uma complexa análise espacial quanto a uso do solo e localização de áreas de riscos eminentes.

Portanto, a presente pesquisa pretende contribuir reunindo boas práticas já existentes em SIG nas administrações públicas e assim disseminar conceitos. Seu foco mostra a utilização da informação espacial no apoio à gestão municipal. Avaliar o quanto se pode melhorar a qualidade dos serviços que a administração pública disponibiliza para os cidadãos e identificar o que é necessário para se obter sucesso num projeto de SIG municipal. 


\section{CONCEITOS DE GEOTECNOLOGIAS}

\subsection{INTRODUÇÃO}

Uma das áreas de conhecimento que mais se desenvolvem no mundo, as Geotecnologias, podem ser descritas como tecnologias que envolvem a informática na manipulação de informações espaciais, ou seja, que possuem uma posição definida no espaço, com coordenadas geográficas. Considerando que aproximadamente $80 \%$ da informação disponível no mundo possua uma componente espacial, as geotecnologias abrangem uma infinidade de atividades. Dentre as geotecnologias estão o SIG - Sistemas de Informação Geográfica, Cartografia Digital, Sensoriamento Remoto por Satélites, GPS - Sistema de Posicionamento Global, Aerofotogrametria, Geodésia e Topografia dentre outros. Considera-se nesta pesquisa três campos de incontáveis aplicações das geotecnologias, que são:

\subsection{GEOPROCESSAMENTO E SISTEMAS DE INFORMAÇÕES GEORREFERENCIADAS}

O geoprocessamento refere-se ao processamento, coleta e visualização de dados georreferenciados (Cartografia, GPS, Sensoriamento Remoto e Topografia), com a finalidade de formar uma base cartográfica.

Com a evolução da tecnologia de geoprocessamento e de softwares gráficos, vários termos surgiram para as várias especialidades e muitas vezes o Geoprocessamento é confundido com os Sistemas de Informações Geográficas SIGs, porém o Geoprocessamento é um conceito mais abrangente que representa qualquer tipo de processamento de dados georreferenciados, enquanto o SIG tem sua ênfase em análises espaciais e modelagens de superfícies.

Os Sistemas de Informações Georreferenciadas ou Sistemas de Informações Geográficas (SIGs) dependem fundamentalmente de mapas e suas relações entre eles, portanto sua história está de alguma forma relacionada com o início da produção de representações gráficas no mundo.

Os primeiros mapas tiveram a função de ajudar a navegação e as operações militares. Nos tempos romanos, os agrimensores ou medidores de terras eram parte importante do governo e com a decadência do Império Romano houve uma diminuição substancial da produção de mapas.

Somente no século XVIII, na Europa com a retomada da organização do Estado, muitos governos realizaram levantamentos e a partir da metade do século 
XVIII, mediante o aparecimento da Cartografia como ciência moderna, surgiram os primeiros mapas com razoável nível de precisão.

O século XIX foi uma época de grande produção de cartas. A partir de 1835 "as técnicas de cartografia, bem como as teorias de ciência social e meio ambiente permitiram a produção de mapeamentos temáticos apresentados de forma compreensível" (SILVA, 2003, p. 52).

Com a Revolução Industrial instaurada, o aumento populacional, aumento na circulação de mercadorias, bem como o uso e ocupação do solo propiciaram diversos mapas temáticos na vida de Londres e outras cidades importantes.

Segundo Silva (2003, p.57), a idéia de se registrar diversos níveis de informação em uma série de mapas temáticos semelhantes, foi estabelecida em uma convenção de cartografia ocorrida em 1876.

Já no século $X X$, as primeiras tentativas de automatizar parte do processamento de dados com características espaciais aconteceram na Inglaterra e nos Estados Unidos, nos anos 50, com o objetivo principal de reduzir os custos de produção e manutenção de mapas. Com a precariedade da informática na época, e o uso das aplicações, pesquisa em botânica, na Inglaterra e estudos de tráfego, nos Estados Unidos, esses sistemas ainda não podem ser chamados de "sistemas de informação".

Nos anos 60, o primeiro SIG surgiu no Canadá com cruzamento de mapas florestais com mapas de ocorrência de focos de incêndios No entanto, eles eram ainda muito precários, não existiam monitores gráficos de alta resolução, os computadores necessários eram muito caros e a mão-de-obra tinha que ser altamente especializada. Não existiam soluções comerciais prontas para uso, cada interessado precisava desenvolver seus próprios programas, o que tornava o processo caro e moroso. (SILVA, 2003, p. 62) Com a capacidade de armazenamento e a velocidade de processamento dos computadores muito baixas, os anos 70 chegam com o desenvolvimento de novos recursos de hardware, deixando mais acessível o desenvolvimento de sistemas comerciais. Foi criada a expressão Geographic Information System e nessa época é que começaram a surgir os primeiros sistemas comerciais de CAD (Computer Aided Design, ou projeto assistido por computador), que melhoraram as condições para a produção de desenhos e plantas para engenharia e serviram de base para os primeiros sistemas de cartografia automatizada. Ainda nos anos 70, foram desenvolvidos alguns fundamentos matemáticos voltados para a cartografia, incluindo questões de geometria 
computacional. No entanto, somente grandes empresas e organizações tinham acesso a essa tecnologia exclusiva para computadores de grande porte.

A década de 80 apresenta uma evolução acelerada na informática e com consequência também para a tecnologia de sistemas de informação geográfica. Até então limitados pelo alto custo do hardware e pela reduzida pesquisa específica sobre o tema, os GIS se beneficiaram da popularização causada pelos avanços da micro informática e do estabelecimento de centros de estudos sobre o assunto. Os EUA, criam o NCGIA - National Centre for Geographical Information and Analysis em 1989 e assim o Geoprocessamento figura como disciplina científica independente.

\subsubsection{Geoprocessamento no Brasil}

O Geoprocessamento no Brasil se deu com o surgimento de vários grupos interessados em desenvolver essa tecnologia, destacando-se o grupo do Laboratório de Geoprocessamento do Departamento de Geografia da UFRJ, que foi responsável pelo desenvolvimento do SAGA (Sistema de Análise GeoAmbiental) em 1983.

Em meados dos anos 80 , foi criado um sistema de automatização de processos cartográficos, pouco depois a empresa MaxiData lançou o MaxiCad, utilizado principalmente para automatização de processos cartográficos de mapeamento. Mais recentemente, o software dbMapa permitiu a junção de bancos de dados relacionais a arquivos gráficos MaxiCAD, produzindo uma solução para desktop mapping para aplicações cadastrais.

Em 1990, a TELEBRÁS, através de seu Centro de Pesquisa e Desenvolvimento, desenvolveu o SAGRE (Sistema Automatizado de Gerência da Rede Externa), para a aplicação de Geoprocessamento no setor de telefonia. Construído com base num ambiente de um SIG (VISION) com um banco de dados cliente-servidor (ORACLE), o SAGRE envolve um significativo desenvolvimento e personalização de software.

O INPE (Instituto Nacional de Pesquisas Espacias) em 1984 criou um grupo específico para o desenvolvimento de tecnologia de geoprocessamento e sensoriamento remoto (a Divisão de Processamento de Imagens - DPI). De 1984 a 1990 a DPI desenvolveu o SITIM (Sistema de Tratamento de Imagens) e o SGI (Sistema Geográfico de Informação), para ambiente PC/DOS, e, a partir de 1991, o SPRING (Sistema para Processamento de Informações Geográficas), para ambientes UNIX e MS/Windows.

O SPRING (Sistema de Processamento de Informações Geográficas) unifica o tratamento de imagens de Sensoriamento Remoto (ópticas e microondas), mapas temáticos, mapas cadastrais, redes e modelos numéricos de terreno. A partir de 1997, 
- SPRING passou a ser distribuido via Internet gratuitamente em português e é amplamente usado no Brasil e no exterior. Atualmente existem diversos aplicativos comerciais em uso no Brasil.

\subsubsection{Popularização do Geoprocessamento}

A evolução dos computadores pessoais na década de 80 e dos sistemas gerenciadores de bancos de dados relacionais, foi difundindo cada vez mais o uso de Sistemas de Informações Geográficas. Nessa década observa-se um grande crescimento do uso de SIGs nas organizações, sempre alavancados pelos custos cada vez menores de hardware e software além de alternativas mais baratas para a construção de bases de dados geográficos.

Nos anos 90 há uma consolidação do Geoprocessamento como instrumento de apoio à tomada de decisões. Instituições do Governo e grandes empresas começaram a investir no uso de softwares disponíveis no mercado como o ArcView da ESRI (Environmental Systems Research Institute) (1992), entre outros. Consolidamse as aplicações que agregavam diversas funções no mesmo sistema (modelagem 3D, analise espacial, processamento digital de imagens, etc), porém os usuários eram só especialistas e a difusão dos beneficios do uso do Geoprocessamento ainda estava no começo.

Desde o final dos anos 90 e início do século XXI, a consolidação do uso da WEB e o uso da Intranet em grandes corporações, populariza cada vez mais o SIG, que passa a fazer uso também do ambiente WEB. Com o aumento da demanda do mercado, os usuários não precisam ser mais especialistas, desde leigos a técnicos, todos podem ter acesso a essa tecnologia. Há também um aumento de sites especializados.

Há uma aproximação neste início dos anos 2000 de grandes empresas de SIG com as tradicionais empresas de tecnologia da informação como a Oracle, Microsoft, Google, etc. e o surgimento do termo "Geotecnologias" para incrementar o mundo de negócios. As principais áreas atingidas com as geotecnologias são as telecomunicações, logística, agronegócios, energia, saneamento, meio ambiente, geomarketing e a gestão de cidades.

E a evolução não para por aí, após o surgimento, a partir de 2005, do Google Maps, do Google Earth e do WikiMapia, usuários da internet que até então não tinham qualquer contato com ferramentas SIG, de uma hora para outra podem ter acesso a qualquer parte do planeta por meio de aplicações que misturam Imagens de Satélite, Modelos 3D e GPS. A Microsoft já anunciou também a sua solução de visualização do Globo terreste em 3D, chamado de Virtual Earth. Fabricantes de celular estimam que 
a venda de aparelhos com GPS vai quadruplicar de 2006 a 2011, de acordo com estudo da empresa de pesquisas iSuppli. Em 2011, serão vendidos 444 milhões de dispositivos móveis mundialmente - em 2006, foram 109,6 milhões, Fator Gis (nov. 2007). Isso significa que em $2011,29,6 \%$ de todos os celulares vendidos estarão equipados com GPS.

A Hewlett-Packard (HP) firmou uma parceria com a provedora de mapas virtuais Maplink para incorporar seus serviços ao aparelho de navegação GPS, lançado em agosto/07 no Brasil. A empresa também vai vender o aparelho para o público consumidor final, e não somente para clientes corporativos.

Montadoras também já fabricam carros com sistemas de rastreamento por satélite, portanto a cada dia mais e mais pessoas entram em contato com o Geoprocessamento, mesmo que em aplicações do dia-a-dia.

\subsection{SISTEMA DE POSICIONAMENTO GLOBAL - GPS}

O GPS (global position system) foi desenvolvido pelo Departamento de Defesa dos Estados Unidos da América - DoD, e custou aproximadamente 10 bilhões de dólares. Entrou em operação a partir de 1995 e utiliza 28 satélites, desses 4 são sobressalentes e 6 são planos orbitais. O controle de sua utilização é exercido também pelo DoD.

Esses satélites, construídos pela empresa Rockwell, foram lançados de fevereiro de 1978 (Bloco I) a 6 de novembro de 2004 (o 29ㅇ); e cada um circula a terra duas vezes ao dia a uma velocidade de 11265 quilômetros por hora e altitude de 20200 quilômetros. Cada um dos satélites emitem constantemente sinais para as estações terrestres e receptores em geral, de seus movimentos orbitais e de tempo preciso através de seu próprio relógio atômico.

Este sistema possibilita o posicionamento em tempo real do receptor, e é dado em latitude, longitude e altitude (coordenadas geodésicas) do sistema WGS84.

O sistema GPS está dividido em três partes: espacial, de controle e utilizador.

- Espacial : satélites em órbita;

- De controle: estações terrestres ao longo da zona equatorial que monitoram as órbitas, sincronizam os relógios atômicos (de altíssima precisão) e atualizam os dados emitidos dos satélites;

- Utilizador: receptor que capta os sinais emitidos pelos satélites. Esse receptor decodifica os sinais emitidos por vários satélites e calcula sua posição com base na sua distância a eles. O receptor precisa de um relógio estável e leitura de quatro satélites pelo menos para determinar seu posicionamento e o tempo. 
Até meados de 2000, o departamento de defesa dos EUA impunha a chamada "disponibilidade seletiva", que consistia em um erro induzido ao sinal impossibilitando que aparelhos de uso civil obtivessem um erro inferior a 90 metros. Porém, o então presidente americano, Bill Clinton, foi pressionado a assinar uma lei determinando o fim dessa interferência no sinal do sistema.

\subsubsection{Aplicações}

Além da utilização inicial para fins militares, aeronáuticos, navais, etc., existe hoje o acesso a aparelhos com menor precisão que estão disponibilizados em automóveis, para agricultores, arqueólogos, guardas florestais, bombeiros, policiais, engenheiros, esportistas em geral, pois seu custo e aplicabilidade estão bastante acessíveis. Rapidamente localiza-se em mapas digitais, escolhe-se a melhor rota, calcula-se a velocidade e a direção do deslocamento e ainda pode-se ter uma visão bem ampla da região que se está percorrendo.

$\mathrm{Na}$ agricultura seu uso também é de grande valia, já que se pode determinar rapidamente a área de determinada cultura já referenciada ao resto da propriedade, associando a ela data de cultivo, quantidade de frutos, acessos a ela, etc. Máquinas agrícolas dotadas de GPS podem armazenar dados sobre a sua produtividade em cada ponto da lavoura, que quando trabalhados em um programa específico, produz um quadro geral da produção na propriedade.

Em estudos científicos mais aprimorados, pode-se utilizar o relógio atômico dos satélites que são extraordinariamente precisos e pode-se registrar em microsegundos (0,000001 segundo) quando um evento ocorreu. Isso permite saber com muita precisão o local onde esse evento ocorreu, por exemplo.

A localização de uma pessoa ou equipamento em grandes áreas ou florestas, torna-se simples com o GPS, e os deslocamentos deles também.

Os aparelhos mais precisos normalmente são também os mais caros e necessitam de mais tempo de leitura dos sinais dos satélites.

Para ilustrar o efeito da tecnologia de GPS na vida cotidiana, uma curiosidade: recentemente, um grupo que afirma representar os 10 mil taxistas de Nova York entrou em greve (22/10/07) para protestar contra a adoção obrigatória de aparelhos de localização GPS e máquinas de cartão de crédito nos táxis oficiais da cidade, reportou o New York Times (In: IDGNow. Disponível em: http://idgnow.uol.com.br/computacao_corporativa. Acesso em 22/10/2007.)

A prefeitura de Nova York tornou obrigatória para os táxis credenciados a adoção de uma série de tecnologias, que incluem um sistema que traça a rota da corrida automaticamente, um sistema de pagamento eletrônico por cartão de crédito e 
débito, um monitor posicionado na parte de trás do carro para que o usuário possa ter acesso a notícias e entretenimento e um sistema que permitirá o envio de informações via mensagem de texto.

Porém, os taxistas argumentam que as tecnologias impõem um alto custo e infringem a sua privacidade, além de ser pouco eficazes. Essa é a segunda greve articulada pela associação - a primeira ocorreu em setembro e teve pouca adesão.

No último mês, a associação dos taxistas processou a cidade na Justiça Federal dos Estados Unidos alegando que a obrigatoriedade de instalar os sistemas de localização seria inconstitucional. Em um julgamento em 28 de setembro, um juiz federal se recusou a derrubar a lei da prefeitura, alegando que o uso da tecnologia como prestação de serviço era mais importante que a privacidade dos taxistas. (In: IDGNow. Disponível em: http://idgnow.uol.com.br/computacao_corporativa. Acesso em 22/10/2007).

\section{4 - SENSORIAMENTO REMOTO}

O termo sensoriamento remoto é definido de diversas formas, sendo talvez a mais abrangente e portanto a mais adotada a definida por Avery e Berlin (1992, p. 18): uma técnica para obter informações sobre objetos através de dados coletados por instrumentos que não estejam em contato físico com os objetos investigados.

Sendo assim, a maneira de conseguir transferir informações sobre o objeto pesquisado sem nenhum contato físico, só pode ser realizada através de transmissão pela Radiação Eletromagnética, pois é a única forma de energia capaz de se propagar pelo vácuo.

Como a Radiação Eletromagnética é considerada uma forma de energia, o Sensoriamento Remoto seria uma interação entre o comprimento de onda específico da Radiação Eletromagnética e os átomos e moléculas do objeto pesquisado.

Quando se fala em objeto pesquisado, refere-se a qualquer matéria que reflita ou emita energia para um sensor que irá captá-la, interpretá-la e armazená-la em um banco de dados para estudos posteriores. Normalmente o Sensoriamento Remoto é utilizado para o estudo da superfície terrestre através de imagens fotográficas ou digitais.

\subsubsection{Princípios Básicos}

Toda a percepção visual que se tem, distingue-se através do comprimento das ondas que os objetos pesquisados emitem ou refletem para o olho humano. Os diferentes comprimentos de ondas eletromagnéticas definem-se nas cores azul (de 0,35 a $0,50 \mu \mathrm{m}$ ), verde (de 0,50 a $0,62 \mu \mathrm{m}$ ) e vermelho (de 0,62 a $0,70 \mu \mathrm{m}$ ); esses 
intervalos variam conforme a fonte de consulta, mas abaixo do azul está o ultravioleta e acima do vermelho está o infravermelho.

Através do princípio da conservação de energia, pode-se afirmar que a energia que incide sobre um objeto é igual a soma da energia refletida, mais a energia absorvida e mais a energia transmitida (caso a matéria desse objeto possua alguma transparência ou condutividade).

Conforme a intensidade da radiação eletromagnética refletida pelo objeto de estudo ao sensor, forma-se a imagem através do comprimento das ondas dentro da região do visível (azul, verde e vermelho) ao ultravioleta que é denominado Espectro Eletromagnético.

Três elementos são fundamentais para o funcionamento de um sistema de Sensoriamento Remoto: Objeto de estudo, Radiação Eletromagnética e um Sensor.

Temos o sensoriamento remoto em três níveis:

- Terrestre: realização de estudos sobre a Refletância, Absorbância e Transmitância dos mais variados objetos, para que possam ser devidamente interpretados futuramente pelos sensores;

- Sub-Orbital: algumas câmeras de vídeo, radares e principalmente fotos aéreas que são utilizadas para produzir mapas;

- Orbital: temos neste grupo os balões meteorológicos e os satélites. Ambos são utilizados para estudos como clima, condições da atmosfera terrestre e previsões do tempo, mas os satélites ainda produzem imagens para o mapeamento e estudo de recursos naturais tais como: degelo nos pólos, queimadas nas florestas, secas, enchentes, possíveis jazidas de recursos minerais e etc.

\subsection{ANÁLISE ESPACIAL}

Uma das operações mais utilizadas em Sistemas de Informação Geográfica é a distribuição espacial de variáveis como: população, tipo de solo ou vegetação, escolas etc. Para isso, basta um banco de dados e uma base cartográfica em que o SIG apresenta um mapa colorido com a disposição espacial do fenômeno. A maioria dos usuários fica apenas nessas operações de visualização, porém é muito importante, seus resultados para conclusões que de fato analisem o espaço.

Um dos primeiros exemplos de análise espacial que se tem relato foi em Londres no século XIX, quando em 1854 ocorria uma das epidemias de cólera na cidade. $\mathrm{Na}$ época não se conheciam os fatores desencadeantes da doença, portanto o médico John Snow utilizando um mapa para localizar as residências dos óbitos pela doença, pode constatar que havia um epicentro da epidemia e que era o mesmo local 
da captação de água, onde a concentração de dejetos era grande. Essa é uma situação típica onde se incorpora o espaço à analise que se deseja fazer. Assim, a relação espacial x dados contribuiu para a compreensão do fenômeno. (Câmara et al., 2004, p.02)

\subsubsection{Tipo de Dados em Análise Espacial}

Segundo Câmara et al. (2004, p.03) a classificação mais utilizada para caracterizar os problemas de análise espacial considera três tipos de dados:

- Eventos ou Padrões Pontuais - fenômenos expressos em pontos localizados no espaço, exemplos: localização de crimes, ocorrências de doenças e localização de espécies vegetais.

- Superfícies Contínuas - estimadas a partir de um conjunto de amostras de campo, que podem estar regularmente ou irregularmente distribuídas, na maioria das vezes é resultante de levantamento de recursos naturais, exemplos: mapas geológicos, topográficos, ecológicos etc.

- Áreas com Contagens e Taxas Agregadas - são dados associados a levantamentos populacionais, como censos e estatísticas de saúde, e que originalmente se referem a indivíduos localizados em pontos específicos do espaço, mas que por razões de confidencialidade são agregados em unidades de análise, geralmente delimitadas por polígonos fechados.

Verifica-se então que a análise espacial lida com dados ambientais e sócioeconômicos. Nos dois casos a análise espacial é composta por um conjunto de procedimentos interligados cuja finalidade é a escolha de um modelo inferencial. Normalmente existe uma fase inicial de análise exploratória, que consiste na apresentação visual dos dados do fenômeno estudado sobre o espaço. Ainda segundo Câmara et al. (2004, p.4. Disponível em: http://www.dpi.inpe.br/gilberto/tutoriais/ analise/cap1.pdf. Acesso em 01/11/2007), "o processo de modelagem é precedido de uma fase de análise exploratória, associada à apresentação visual dos dados sob a forma de gráficos e mapas e a identificação de padrões de dependência espacial no fenômeno em estudo."

Na análise de padrões pontuais, o objeto de interesse "é a própria localização espacial dos eventos em estudo". Estudando a distribuição espacial destes pontos, testando hipóteses sobre o padrão observado: se é aleatório, ou se apresenta aglomerados ou uma distribuição regular.

$\mathrm{Na}$ análise de superfícies, o objetivo é reconstruir a superfície da qual se retirou e mediu as amostras. Por exemplo um mapa de solo, onde são retiradas 
amostras, temos a princípio um mapa com pontos de coletas e a partir daí estima-se um modelo de dependência espacial que permite a interpolação da superfície apresentada no mapa.

$\mathrm{Na}$ análise de áreas, na maioria dos casos, os dados são provenientes de levantamentos populacionais, como censos, estatísticas de saúde ou cadastramento de imóveis. São áreas usualmente delimitadas por polígonos fechados onde se supõe haver homogeneidade interna, porém é claro que inúmeras vezes não há um grupo homogêneo e sim determinado por indicadores que calculados representam a média. Por exemplo um mapa de grupos sociais que vivem em habitações precárias e áreas nobres.

Os Sistemas de Informação Geográfica realizam o tratamento computacional de dados geográficos e armazenam sua geometria e também os atributos dos dados que estão georreferenciados. Seus componentes de desenvolvimento incluem: o usuário, que define como o sistema vai ser operado e controlado; a entrada e integração de dados; funções de processamento gráfico e de imagens; as consultas e a análise espacial; visualização e plotagem.

\subsubsection{A captura de dados para SIG}

A organização de banco de dados geográficos mais utilizada é o Sistema Gerenciador de Banco de Dados (SGBD) relacional, como o Acess, amplamente difundido no mercado. A entrada ou captura de dados para alimentar o SGBD é uma das etapas do processo que requer cuidados especiais. São procedimentos que geralmente correspondem a $75 \%$ dos esforços físicos, financeiros e intelectuais de um projeto de SIG, pois o SGBD relacional não conhece a estrutura gráfica externa, existindo o sério risco de se introduzir inconsistências no banco de dados geográfico, uma vez que o modelo georrelacional não oferece recurso para a garantia automática da integridade dos dados.

Câmara et al. (2004, p.08) definem que as representações geométricas utilizadas podem ser:

- Pontos 2D: um ponto é um par ordenado de coordenadas $X$ e $Y$ espaciais. Indica a ocorrência de um evento;

- Polígonos: um polígono é um conjunto de pares ordenados de coordenadas $\mathrm{X}$ e $\mathrm{Y}$ espaciais, onde o primeiro ponto coincide com o último formando uma região fechada no plano;

- Amostras: são pares ordenados $X, Y$, e $Z$, nos quais $X$ e $Y$ indicam as coordenadas e $Z$ indica o valor do fenômeno estudado para essa localização; 
- Grade regular: é uma matriz onde cada elemento está associado a um valor numérico, que por sua vez está associada a uma região da superfície terrestre, a partir da coordenada inicial;

- Imagem: é uma matriz onde cada elemento está associado a um valor inteiro utilizada para a visualização, normalmente na faixa entre 0 e 255 . A matriz é a representação gráfica de uma grade regular.

No modelo georrelacional, os atributos de cada objeto estão dispostos em uma tabela onde as linha correspondem aos dados e os nomes das colunas são os nomes dos atributos. Cada objeto geográfico está associado a um identificador único, através do qual é feita uma ligação lógica entre seus atributos e sua representação geométrica.

Com relação aos três tipos básicos de dados usados na análise espacial, as áreas, representadas graficamente por um polígono fechado tem seus atributos armazenados numa tabela de um SGBD relacional. Cada polígono recebe um identificador que está associado ao mesmo tempo ao polígono que o delimita e à linha da tabela que contém seus atributos. Os eventos ou padrões pontuais também se associam a um SBGD relacional, cada evento está associado a um identificador que é a ligação entre o arquivo de coordenadas geográficas e a tabela no banco de dados. Já nas superfícies, o mais comum é tratar apenas com arquivos gráficos, sem armazená-los no SGBD relacional, assim os dados de entrada são arquivados como amostras, adicionadas a um polígono com os limites da região de estudo, produzindo uma grade regular que descreve de forma aproximada o fenômeno da região estudada. In: CÂMARA, Gilberto; MONTEIRO, Antonio Miguel; FUCKS, Suzana D.; CARVALHO, Marina Sá. Analise Espacial e Geoprocessamento. São José dos Campos, 2004, p.10. Disponível em: http://www.dpi.inpe.br/gilberto/tutoriais/ analise/cap1.pdf. Acesso em 01/11/2007.

\subsubsection{Dependência Espacial}

Entender o conceito de dependência espacial é o primeiro passo da análise dos fenômenos espaciais.

Uma ocorrência, seja ela natural ou social, estabelece relações que dependem da distância com outras ocorrências. Por exemplo, se há desmatamento num trecho de vegetação é provável que locais próximos a essa amostra também sejam encontrados desmatamentos e a relação diminui à medida que esses dados ficam mais dispersos.

Câmara et al. (2004, p.11) definem que a dependência espacial é também chamada de autocorrelação espacial, derivado do termo estatístico de correlação. 
Para medir a autocorrelação espacial, utilizam-se diferentes indicadores, todos baseados na mesma ideia: verificar como varia a dependência espacial, a partir da comparação entre os valores de uma amostra e seus vizinhos. Quando valores significativos de índices de correlação espacial ocorrem, são evidências de dependência espacial, tornando inválida a independência das amostras, que nesses casos devem levar explicitamente em conta o espaço em que se encontram.

\subsubsection{Inferência Estatística para Dados Espaciais}

$\mathrm{Na}$ dependência espacial, as inferências estatísticas não são tão eficientes quanto no caso de amostras independentes do mesmo tamanho. Há variações maiores para as estimativas, níveis menores para os testes de hipóteses e um ajuste pior para os modelos estimados.

Segundo Câmara et al. (2004, p.12): "Na maior parte dos casos, a perspectiva mais apropriada é considerar os dados espaciais não como um conjunto de amostras independentes, mas como uma única realização de um processo estocástico" ".

\subsubsection{Estacionariedade e Isotropia}

Câmara et al. (2004, p.13) descrevem:

Os principais conceitos estatísticos que definem a estrutura espacial dos dados relacionam-se aos efeitos de $1^{\underline{a}}$ e $2^{\underline{a}}$ ordem. Efeito de $1^{\underline{a}}$ ordem é o valor esperado, isto é, a média do processo no espaço. Efeito de $2^{\underline{a}}$ ordem é a covariância entre as áreas (...). Um conceito importante neste tipo de estudo é o de estacionareidade. O processo é considerado estacionário se os efeitos de $1^{\underline{a}}$ e $2^{\underline{a}}$ ordem são constantes, em toda a região estudada, ou seja, não há tendência. Um processo é isotrópico se, além de estacionário, a covariância depende somente da distância entre os pontos e não da direção entre eles. In: CÂMARA, Gilberto; MONTEIRO, Antonio Miguel; FUCKS, Suzana D.; CARVALHO, Marina Sá. Analise Espacial e Geoprocessamento. São José dos Campos, 2004. Disponível em: http://www.dpi.inpe.br/gilberto/tutoriais/analise/cap1.pdf. Acesso em 01/11/2007.

Num determinado processo espacial, a hipótese de estacionareidade pode ser definida a partir de procedimentos de análise exploratória e estatísticas descritivas, considerando-se sempre a localização espacial.

Quando a dependência espacial é a mesma em todas as direções, tem-se um fenômeno isotrópico e quando a estrutura de covariança ${ }^{2}$, além de variar com a distância, também varia em função da direção chama-se fenômeno anisotrópico.

\footnotetext{
${ }^{1}$ Estocástico: adj.Diz-se dos processos que não estão submetidos senão a leis do acaso.
} 


\subsubsection{O Processo da Análise Espacial}

A análise espacial é composta por um conjunto de métodos interligados com a finalidade de criar um modelo que considere o relacionamento espacial do fenômeno. Eles incluem a adoção de métodos genéricos de análise exploratória e visualização de dados. Visualizados em mapas, pode-se observar a distribuição da ocorrência estudada e buscar a existência de padrões na distribuição espacial, estabelecer hipóteses e selecionar o melhor modelo inferencial ${ }^{3}$ a ser aplicado.

Os modelos inferenciais espaciais normalmente são apresentados em três grandes grupos, Câmara et al. (2004, p.14): variação contínua, variação discreta e os processos pontuais. Num processo de análise espacial podem estar envolvidos um, dois ou os três grupos.

A partir do exemplo utilizado por Câmara et al. (2004, p.14), pode-se perceber quais as diferenças e como estes grupos interagem num mesmo processo:

O exemplo utilizado é o caso de Leishmaniose visceral que é transmitida por mosquitos e atinge animais e também o homem. Alguns surtos epidêmicos surgiram em cidades brasileiras: Belo Horizonte, Araçatuba, Cuiabá, Teresina e Natal. O controle da doença está no combate ao inseto e na eliminação de cães da área de foco, definido em raio de 200 metros do caso humano ou canino. A doença é grave e apesar da aplicação das medidas de combate o problema ainda está sem controle. A aplicação da análise espacial neste caso pode auxiliar e muito:

- Determinar o raio de dispersão do mosquito em torno do seu habitat:

$\mathrm{Na}$ modelagem da ocorrência do vetor da Leishmaniose, dois modelos podem ser utilizados para estimar o raio de dispersão do mosquito e definir a área de borrifação ao redor de casos de doenças:

Variação contínua: objetivando gerar superfícies contínuas para determinar as áreas de maior risco a partir de uma amostra de locais de coleta de mosquitos (amostra de pontos descontínuos).

Processos pontuais: objetivando modelar a probabilidade de captura de mosquitos. Neste caso, a variável aleatória é o local onde o mosquito foi capturado e não a presença ou ausência de mosquito.

\footnotetext{
${ }^{2}$ Co-variância. s.f. Em estatística, média dos produtos dos termos homólogos de duas variáveis centradas.

3 Inferência: s. f.1. Ato ou efeito de inferir.2. Dedução, conclusão. As técnicas geoestatísticas de inferência, conhecidas por krigeagem, consideram os atributos ambientais como variáveis aleatórias o que possibilita a modelagem das incertezas associadas às inferências. Essas técnicas têm sid o utilizadas, com frequência, para espacialização de atributo ambientais amostrados pontualmente.
} 
- Determinar qual é o ambiente preferencial de reprodução do mosquito em áreas urbanas:

Identificar numa região as áreas de concentração de algumas características ambientais que propiciam o aparecimento do mosquito, já sabendo que eles se reproduzem no solo e em matéria orgânica em decomposição como pés de bananeira e folhas caídas. Assim poderiam ser utilizados os modelos de variação contínua para inferir superfícies com os valores desses atributos.

- Determinar se há relação entre a prevalência canina e as condições socioeconômicas da população:

Sabe-se que o mosquito isoladamente não perpetua a epidemia, sabe-se também que a resistência dos cães à doença depende do estado nutricional e por conseqüência da situação socioeconômica de seus donos e por último da aceitação da eliminação do cão doente (também relacionada à renda). Aqui é necessário estudar em conjunto: a incidência da doença em cães, o perfil sócio-econômico da população e a prevalência de casos em humanos. Utilizando para este caso o modelo de variação discreta, pois é necessária a informação de indicadores socioeconômicos da região agrupados por área. O resultado é o estudo da relação entre os diferentes indicadores considerando sua estrutura espacial.

Existem vantagens e desvantagens da utilização deste ou daquele modelo, a escolha final deverá ser o modelo inferencial que melhor se ajuste aos dados e tenha o maior potencial de contribuir para a compreensão do caso estudado.

Algumas vezes o fenômeno analisado apresenta variação espacial discreta: pontos isolados no espaço, mas frequentemente os modelos discretos são utilizados por facilidade, como, por exemplo, a disponibilidade de dados exclusivamente por áreas. Já "uma das vantagens dos modelos contínuos é que a inferência não se limita a áreas arbitrariamente definidas", como diz Câmara et al. (2004, p.16).

O Processo Pontual é definido como um conjunto de pontos irregularmente distribuídos em um terreno, cuja localização é o próprio objeto de estudo que tem por objetivo compreender seu mecanismo gerador. No caso de existência de uma determinada doença numa região, verifica-se se existe um padrão geográfico com maior probabilidade de ocorrências, e o produto final pode ser um mapa com a intensidade do evento.

Quando a análise é de superfícies, o tipo dos dados são amostras de campo e matrizes, como por exemplo, depósitos minerais. Apresenta-se, neste caso, uma variação contínua cujos valores podem ser conhecidos em todos os pontos da área estudada. A estimativa desse processo estocástico pode ser feita de forma 
completamente não paramétrica ou a partir de estimadores de krigeagem ${ }^{4}$, estes modelos de estimação de superfícies são denominados de geostatística.

Para a análise de áreas (polígonos e atributos), por exemplo, dados censitários, não se dispõe da localização exata dos eventos, mas de um valor agregado por área, chamando este caso de variação discreta, cujo o objetivo é modelar o padrão de ocorrência espacial do fenômeno geográfico em estudo, segundo Câmara et al. (2004, p.18).

Os especialistas das mais diversas áreas, como geografia, geologia, saúde pública, etc., desenvolvem teorias sobre os fenômenos, utilizando as técnicas de visualização dos SIGs, que podem conter também hipóteses sobre o comportamento espacial dos dados. A partir disso, é necessário que o especialista ainda formule os modelos inferenciais quantitativos, que podem ser submetidos a testes de validação e de corroboração, através dos procedimentos de Análise Espacial, os resultados numéricos podem dar suporte ou rejeitar conceitos qualitativos iniciais, Câmara et al. (2004, p.19).

Para o sucesso de um projeto de SIG é necessário um planejamento inicial que envolva todas as etapas e não se pode esquecer da importância da atualização do sistema para haver continuidade. Deve-se considerar, principalmente, os benefícios que serão adquiridos ao longo do trabalho, tempo e recursos que serão investidos na fase inicial, bem como em todas as etapas até a análise espacial e assim, não só o diagnóstico de situações, mas suas causas e possíveis soluções. É muito importante também, o estudo multidisciplinar proporcionado pelo conhecimento de especialistas de várias áreas, para um resultado integrado, Machado (2009, p.7-10).

Quanto maior o conhecimento do problema, maior são as chances de resolvêlo e muitas vezes é necessário combinar as diferentes abordagens de análise. Essas técnicas quantitativas de Análise Espacial devem favorecer o conhecimento dos especialistas e nunca ser usadas como um fim em si. Para uma Análise consistente

\footnotetext{
4 A krigeagem é um estimador de média ponderada local que utiliza o critério de minimização da variância de estimação para definir os pesos associados a cada amostra considerada. Além disso, esse critério permite a criação de um mapa de incertezas de estimação associado ao mapa de atributos espacializados. Estas são as principais vantagens do interpolador de krigeagem em relação a outros interpoladores de média ponderada, cujos ponderadores são, em geral, definidos por paradigmas subjetivos. Porém as variâncias de krigeagem estão relacionadas a distribuição espacial das amostras e não informam sobre a variabilidade do atributo na região de interesse. A técnica de inferência conhecida como krigeagem por indicação, que é uma técnica de inferência estatística não linear, permite a estimativa dos valores, e também das incertezas associadas ao atributo, durante o processo de espacialização de uma propriedade amostra da. Essa técnica baseia-se na premissa de que a propriedade em estudo é considerada uma variável aleatória em cada posição não amostrada. As inferências dos valores e das incertezas são obtidos a partir da construção da função de distribuição acumulada, condicionada aos dados amostrados, de cada variável aleatória.
} 
deve-se ter o domínio dos fundamentos teóricos de Geoprocessamento e Estatística Espacial, além de uma metodologia sólida de trabalho, englobando modelos matemáticos (software) com a interpretação subjetiva (especialista).

Entende-se, portanto, que para a Análise Espacial e o Geoprocessamento não existe uma aplicação universal nem um meio de automação de técnicas estabelecidas e sim usuários com uma postura ativa e crítica dos processos. 


\section{GOVERNO ELETRÔNICO}

\subsection{INTRODUÇÃO}

\subsubsection{Conceitos}

A expressão usada e-Government pode ser traduzida como a utilização das tecnologias de informação e de comunicação (TIC), para aproximar o cidadão do governo, bem como para melhorar a eficiência, eficácia, transparência e responsabilidade do Governo. Seja este em esfera Federal, Estadual ou Municipal.

Pode-se definir também o governo-eletrônico como a utilização da Internet/Intranet e da World Wide Web (www) como meio de prestação de serviços e informações ao cidadão, nesse caso não só o cidadão pessoa física, mas também instituições privadas e públicas.

Levando em consideração essas novas formas de relacionamento do governo e seus resultados propiciados pela inserção das tecnologias da informação e comunicação, pode-se dizer que estamos vivendo algo próximo de uma "revolução" na forma de governar, historicamente diferente das formas anteriores.

Através do Governo Eletrônico, modificam-se procedimentos administrativos dos órgãos públicos, redesenham-se processos, altera-se a relação com os cidadãos e a gestão tornar-se mais eficaz. É a oportunidade que pode transformar radicalmente a administração do Estado.

Serão destacados, então, pontos fundamentais para a elaboração desta dissertação. A contribuição do Governo Eletrônico na melhora dos serviços prestados e consequentemente na melhora da qualidade de vida da população. Serão comentadas a importância das políticas públicas, a transparência dos governos, a aceitação pública, economia, meio ambiente e melhores práticas.

\subsubsection{Os Estágios da Informatização dos Governos}

Os estágios da evolução das TICs no Estado podem ser dividido em três fases:

$1^{\text {a }}$ - Os governos passaram a usar os computadores pessoais nas repartições públicas:

O início do governo eletrônico se deu com o advento do computador pessoal, início dos anos 80, informatizando processos que antes eram em papéis. Nessa 
primeira fase, as funções não foram substituídas, houve uma excessiva digitação de documentos que ainda não circulavam eletronicamente.

$2^{\text {a }}$ - Incorporou-se a tecnologia da informação e comunicação entre as repartições:

Nessa etapa, os processos internos foram ligados através das TICs e auxiliavam o conjunto de repartições públicas na troca de dados, porém ainda haviam muitos entraves, como a cultura organizacional e a valorização da detenção da informação que era considerada um status sobre outras repartições.

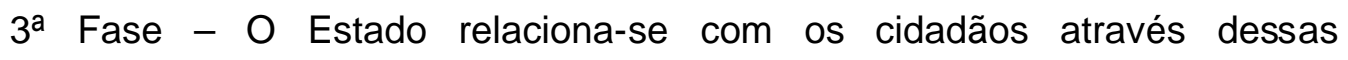
tecnologias:

Começa com a generalização da internet, redução de custos dos computadores, surgiram os primeiros sites governamentais e estabeleceu-se um canal de comunicação com cidadãos e empresas.Segundo Parente,

A expressão Governo Eletrônico, no governo Federal Brasileiro, passou a ser utilizada em 1996. Não havia, até então, política específica e as atividades corriam de maneira esparsa e não integrada, decorrentes do emprego convencional dos recursos de tecnologia da informação e comunicação. In: PARENTE, P. Política brasileira de Governo eletrônico in: E-government: o governo eletrônico no Brasil. Ferrer, Florência; Santos, Paula (Org.). São Paulo. Saraiva: 2004 p.46

\subsubsection{Tipos de Governo}

O governo brasileiro, bem como governos internacionais e a ONU, dividem em 4 categorias de usuários para aplicação do governo-eletrônico, são elas:

\section{a) Governo para Cidadão - G2C (Government to Citizen)}

São as iniciativas do governo voltadas para as necessidades dos cidadãos. Disponibilizam-se produtos e/ou serviços administrativos de informação e transação com a população.

Alguns exemplos de trâmites para cidadãos:

- Declaração de Imposto de Renda;

- Divulgação de concursos públicos;

- Concessão de documentos pessoais;

- Registro de veículos; 
- Emissão de guias para pagamento de impostos;

- Registro de boletim de ocorrência policial;

- Acesso a documentos de bibliotecas públicas, entre outros.

As vantagens para os cidadãos são inúmeras: economia de tempo e deslocamento até as repartições, serviços disponíveis 24 horas, 7 dias por semana. Uma tendência em sites de governo para os cidadãos é a utilização de um portal único de entrada e a organização dos serviços e informações de forma simples e intuitiva (life events), seguindo eventos importantes da vida das pessoas.

Exemplos de sites de governo eletrônico voltado para os cidadãos:

Brasil:

Governo Federal (Rede Governo): <http:/www.redegoverno.gov.br/>

Governo Estadual de São Paulo (Cidadão.sp) : <http:/www.cidadao.sp.gov.br/>

Mundial:

Governo de Singapura (Singov) : <http:/www.gov.sg/>

Governo dos Estados Unidos (FirstGov): <http:/www.usa.gov/>

Governo do Chile (Tramite Fácil): : <http:/www.tramitefacil.gov.cl/>

b) Governo para Empresa - G2B (Government to Business)

São os sites e informações destinadas às necessidades das empresas.

Exemplos de trâmites para empresas:

- Pagamento de benefícios sociais aos trabalhadores;

- Declaração de Impostos relativos às atividades das empresas;

- Emissão de certidões de regularidade;

- Emissão de guias para pagamento de impostos;

- Nota fiscal eletrônica;

- Consulta a dados com registros e licenças;

- Processos de compras públicas;

- Informações de atividades comerciais; 
- Trâmites relativos ao comércio exterior.

Além das vantagens para as empresas na agilização de processos e informações para tomada de decisões, os governos também se beneficiam dessa relação, pois têm maior fiscalização e controle sobre a arrecadação de impostos.

Exemplos de sites voltados às empresas:

Brasil:

Governo do Estado da Bahia: Bahiainvest/Bahiaexport $<$ http:/www.bahiainvest.com.br/>

Portal Sebrae: <http:/www.sebrae.com.br/>

Governo do estado de São Paulo: <http:/www.cidadao.sp.gov.br/>

Mundial:

Governo da Irlanda: Basis - Business Access to State Information and Service: <http:/www.basis.ie/>

Governo da Austrália: E-Business Guide: <http:/www.ebusinessguide.gov.au/>

c) Governo para Empregado - G2E (Government to employee)

São os sites e informações destinadas às necessidades dos próprios funcionários públicos.

Exemplos de trâmites para funcionários:

- Capacitação de servidores públicos;

- Informações sobre leis, regulamentos internos, benefícios;

- Informações sobre salários, contra-cheque, licenças;

- Gestão e fluxos de trabalhos internos.

Os benefícios são a otimização de trabalhos, diminuição de custos e difusão da informação entre os funcionários.

Exemplos de sites para funcionários públicos:

Brasil:

Portal do Servidor do Governo da Bahia: <http:/www.portaldoservidor.ba.gov.br/> 
Mundial:

Estados Unidos: Federal Employees:

<http:/www.usa.gov/Federal_Employees>

d) Governo para Governo - G2G (Government to Government)

São os sites e informações destinadas às necessidades de coordenação e integração entre as diferentes instituições públicas.

Exemplos de trâmites entre o governo:

- Compartilhamento de informações e bases de dados;

- Orçamentos;

- Compras governamentais;

- Elaboração de estratégias, leis, políticas públicas;

- Regulamentação;

- Divulgação de dados estatísticos.

Os benefícios advem da interação das esferas do governo, no compartilhamento de base de dados e informações essenciais ao poder público para a tomada de decisões.

Exemplos de sites para governos:

Brasil:

Portal da Transparência: <http:/www.portaldatransparencia.gov.br/>

Mundial:

Chile - Sistema de Informação para a Gestão Financeira (SIGFE):

$<$ http:/www.sigfe.sigfe.cl>

\subsubsection{Fases de Desenvolvimento do Governo Eletrônico}

De acordo com Nobre e Barruncho (Acesso em 02/11/2007), para se classificar a estrutura do governo-eletrônico deve-se levar em conta pontos mensuráveis como:

- existência de um website governamental;

- existência de um portal único na internet de entrada aos serviços do governo; 
- existência de estruturas subnacionais em website;

- existência de capacidade de realização de operações transacionais.

Num contexto evolutivo, pode-se considerar quatro estágios de governoeletrônico fundamentais, porém os estágios não são dependentes uns dos outros, nem é necessário que acabe um para iniciar outro :

\section{a) Presença}

Presença oficial do governo na Web. Os governos colocam on-line informações básicas tipo estruturas organizacionais, localização, leis, histórico de sua fundação etc. Não existe ainda interação com o usuário.

\section{b) Interação}

Os usuários podem obter formulários, enviar correio eletrônico aos funcionários e interagir via Web. Esta interação é através de funções básicas como: envio de formulários de comentários ou opiniões. Essa fase já permite a participação cidadã e propicia o aumento da confiança nas repartições públicas.

\section{c) Transação}

Os usuários podem pagar por serviços via Web e realizar operações diversas pela Internet. Disponibilizando transações eletrônicas o Estado obtém economias de custo, melhorias na oferta dos serviços além de gerar mais confiança e transparência em suas ações.

"Aqui os governos implementam iniciativas equivalentes ao comércio eletrônico das instituições privadas." In: UNIVERSIDADE DO SUL DE SANTA CATARINA. Governo Eletrônico: estratégias de elaboração, desenvolvimento e implementação de projetos. $2^{\text {a }}$ edição. Palhoça: Unisulvirtual, 2008. p. 59.

\section{d) Transformação}

É quando ocorre a integração completa dos serviços através das fronteiras administrativas. São mudanças importantes na forma de governar. É necessária uma modificação na estrutura organizacional para que o governo possa fornecer esse serviço.

São inúmeros os benefícios da aplicação do governo eletrônico, em suas diversas esferas de atuação. Dentre alguns, podemos citar a redução de custos de operações que eram realizadas de forma convencional e passaram a ser eletrônicas.

\section{Exemplos:}




\section{Governo do Estado de São Paulo}

Apenas com o pagamento do imposto automotivo IPVA pela Internet e em caixas automáticos, reduziu-se o custo por transação de $R \$ 21$ para $R \$ 0,66$ - segundo estudo da Fundação de Amparo à Pesquisa de São Paulo - Fapesp em 2003. In: UNIVERSIDADE DO SUL DE SANTA CATARINA. Governo Eletrônico: estratégias de elaboração, desenvolvimento e implementação de projetos. $2^{\underline{a}}$ edição. Palhoça: Unisulvirtual, 2008. p. 63

Grupo de usuário: GTC

Estágio: Transacional

Quadro 01 - Site da Secretaria da Fazenda do Estado de São Paulo

\section{Governo Federal Brasileiro}

www. receita.gov.br

O Brasil foi pioneiro no mundo no envio de Declarações de Imposto de Renda pela Internet. O ReceitaNet, transmite mais de 60 tipos diferentes de declarações de pessoa física e jurídica e reduziu de US\$ 1,1 para as declarações em formulário para US\$ 0,13 para as declarações pela Internet, com duração média de 2,4 segundos. UNIVERSIDADE DO SUL DE SANTA CATARINA. Governo Eletrônico: estratégias de elaboração, desenvolvimento e implementação de projetos. $2^{\underline{a}}$ edição. Palhoça: Unisulvirtual, 2008. p. 64

Grupo de usuário: GTC Estágio: Transacional

Quadro 02 - Site da Receita Federal - Brasil

\section{Governo do Texas - EUA} www.dir.state.tx.us/egov/report/finalrpt.htm

Por exemplo: o sistema de renovação on-line de licenciamentos de veículos, reduziu de US\$6,60 para US\$1,60. 


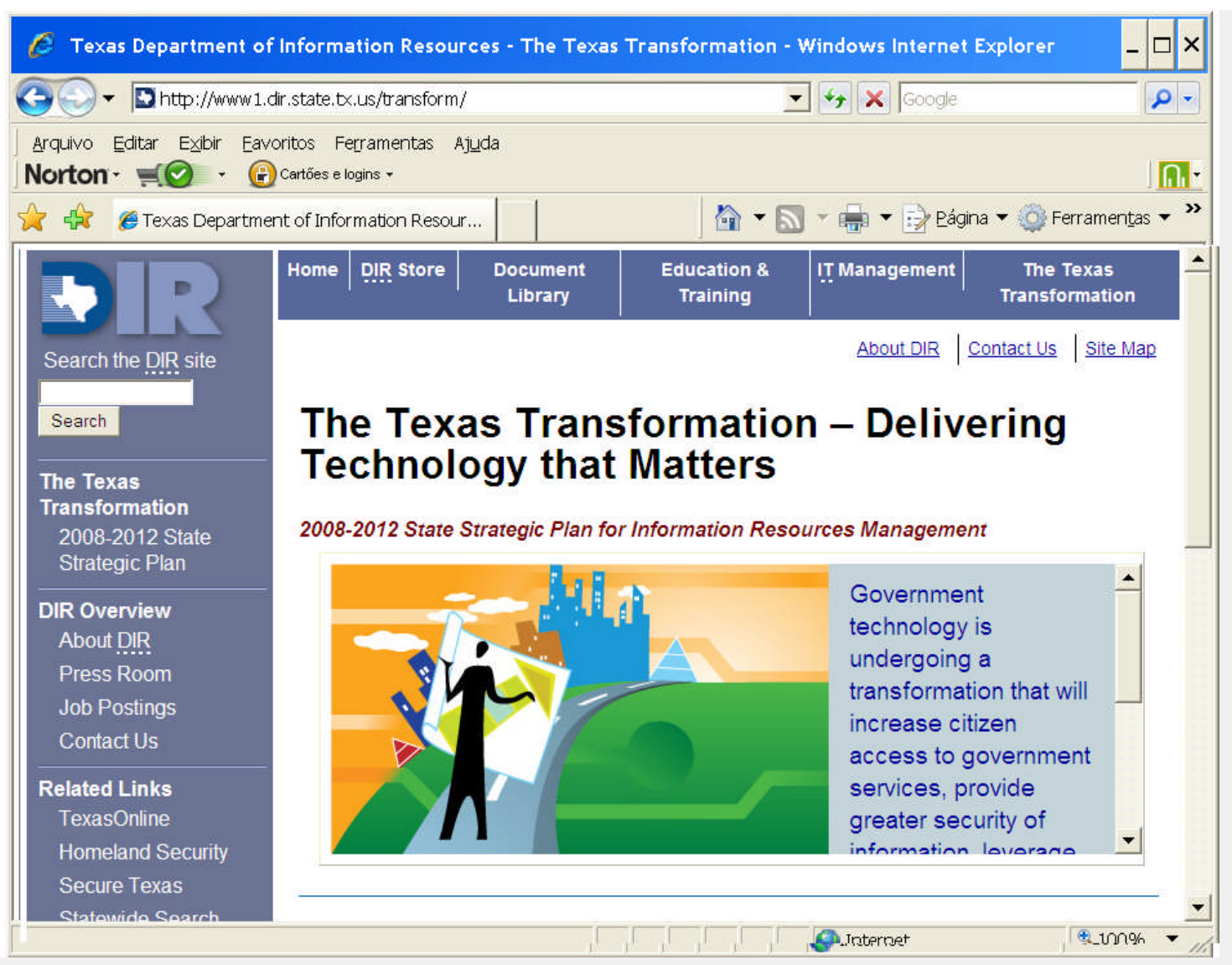

UNIVERSIDADE DO SUL DE SANTA CATARINA. Governo Eletrônico: estratégias de elaboração, desenvolvimento e implementação de projetos. $2^{\underline{a}}$ edição. Palhoça: Unisulvirtual, 2008. p. 64

Grupo de usuário: GTC

Estágio: Transacional

Quadro 03 - Site do Governo do Texas - EUA

A seguir alguns aspectos dos benefícios da aplicação do governo eletrônico:

- Redução de custos de operações;

- Redução de tempo;

- Serviços mais personalizados, criação de novas formas organizacionais;

- Maior participação cidadã e fortalecimento da democracia;

- Maior confiança nas repartições governamentais;

- Aumento da transparência das ações e consequente combate à corrupção;

- Alcance a cidadãos em locais de difícil acesso e menos povoados; maior abrangência do governo;

- Facilidade de treinamento de funcionários públicos, melhorando sua atuação. 


\subsection{ESTRATÉGIAS DE GOVERNO ELETRÔNICO}

\subsubsection{Marco Inicial}

Em alguns países desenvolvidos, o processo de incorporação das TICs nos processos governamentais teve início nos primeiros anos da década de 90 .

Os Estados Unidos, foram um dos primeiros países a lançar oficialmente em 1993 o programa National Performance Review, que foi o ponto de partida de uma estratégia de governo eletrônico. Em 1998, no governo Clinton, o programa foi chamado de National Partnership for Reinventing Government.

No Brasil, o marco inicial a Política de Governo Eletrônico foi no ano de 2000, com a criação de um grupo de trabalho interministerial com a finalidade de examinar e propor normas e diretrizes relacionadas com as novas formas eletrônicas de interação. O GTTI - Grupo de Trabalho em Tecnologia da Informação, concentrou esforços em três das sete linhas de ação do programa Sociedade da Informação do Ministério da Ciência e Tecnologia. São elas:

- Universalização de serviços;

- Governo ao alcance de todos;

- Infra-estrutura avançada.

A partir daí, em julho de 2000, o GTTI apresentou um relatório preliminar com um diagnóstico da situação da infra-estrutura, serviços existentes, desejados e também a situação da legislação.

Assim, em outubro de 2000 foi criado o Comitê Executivo de Governo Eletrônico - CEGE, através de um Decreto Federal, cujos objetivos são: formular políticas, estabelecer diretrizes, coordenar e articular as ações de implantação do Governo Eletrônico. Esse Comitê, atendendo a um Plano de Metas, apresentou o importante documento de "Politica de Governo Eletrônico" ainda em 2000.

Em 2002, a Secretaria de Logística e Tecnologia da Informação do Ministério do Planejamento, com a colaboração dos membros do CEGE, publicou um documento com o balanço das atividades nos 2 anos de Governo Eletrônico e criou base para a continuidade do Programa.

Em 2003, outro Decreto da Presidência da República, criou 8 Comitês Técnicos de Governo Eletrônico, a saber:

- Implementação do Software Livre;

- Inclusão Digital;

- Integração de Sistemas;

- Sistemas Legados e Licenças de Software;

- Gestão de Sítios e Serviços On-line; 
- Infra-Estrutura de Rede;

- Governo para Governo - G2G e

- Gestão de Conhecimentos e Informação Estratégica.

"O Ministério do Planejamento, Orçamento e Gestão, através da Secretaria (SLTI), exerce as atribuições de Secretaria-Executiva e garante o apoio técnicoadministrativo necessário ao funcionamento do CEGE e supervisiona os trabalhos dos Comitês Técnicos interagindo com seus coordenadores." BRASIL. Histótrico do governo eletrônico. Disponível em: <http://www.governoeletronico.gov.br/ogov.br/historico>. Acesso em: 12 mar. 2009.

Destaca-se aqui a importância do comprometimento do Executivo para que sejam implantadas políticas públicas, necessárias ao sucesso de um amplo projeto nacional. Segundo Matuzawa:

\footnotetext{
Um conjunto coordenado de estratégias e ações empreendidas pelo Estado, através das suas diferentes instâncias, para integrar tecnologias da informação e comunicação (TIC) aos processos governamentais, com o objetivo de gerar maiores níveis de eficiência na administração, controle e transparência na tomada de decisões e participação cidadã. In: UNIVERSIDADE DO SUL DE SANTA CATARINA. Governo Eletrônico: estratégias de elaboração, desenvolvimento e implementação de projetos. $2^{\underline{a}}$ edição. Palhoça: Unisulvirtual, 2008. p. 79
}

\subsubsection{As Diretrizes do Governo Eletrônico no Brasil}

O projeto de Governo Eletrônico do Brasil está fundamentado em sete diretrizes estratégicas, são elas:

1 - A prioridade do Governo Eletrônico é a promoção da cidadania;

2 - A Inclusão Digital é indissociável do Governo Eletrônico;

3 - O Software Livre é um recurso estratégico para a implementação do Governo Eletrônico;

4 - A gestão do conhecimento é um instrumento estratégico de articulação e gestão das políticas públicas do Governo Eletrônico;

5 - O Governo Eletrônico deve racionalizar o uso de recursos;

6 - O Governo Eletrônico deve contar com um arcabouço integrado de políticas, sistemas, padrões e normas;

7 - Integração das ações de Governo Eletrônico com outros níveis de governo e outros poderes. 
(Disponível em: <http://www.governoeletronico.gov.br/ o-gov.br/principios>. Acesso em: 12 mar. 2009.)

Estas diretrizes estão baseadas em três componentes estratégicos básicos:

a) Programa Nacional de Governo Eletrônico (e-serviços)

Para o Governo Federal, o principal alvo de entrega de serviços eletrônicos é o cidadão e não mais os órgãos do Governo Federal ou serviços mais fáceis de serem implementados. Para os cidadãos o que interessa é receber o serviço com o mínimo de custo e tempo; pouco importa saber quais órgãos do governo estão envolvidos. Segundo Loch, estas ações vem sendo desenvolvidas com as seguintes diretrizes estratégicas:

- Implantar de forma unificada serviços por meios eletrônicos no Governo Federal;

- Integrar outros níveis de governo na prestação de serviços;

- Desenvolver e-serviços orientados por eventos da vida dos cidadãos e demais setores sociais;

- Definir e implantar padrões de usabilidade e acessibilidade para e-serviços;

- Definir canais de entrega para o conjunto da população;

- Avaliar e monitorar a evolução de e-serviços em âmbito nacional a partir de melhores práticas. In: UNIVERSIDADE DO SUL DE SANTA CATARINA. Governo Eletrônico: estratégias de elaboração, desenvolvimento e implementação de projetos. 2ª edição. Palhoça: Unisulvirtual, 2008. p. 143.

Para tanto, o governo realiza o Diagnóstico Nacional de Governo Eletrônico que busca identificar as cadeias de relacionamento, mapear a oferta e a demanda de interações e definir os múltiplos canais de relacionamento dos cidadãos e das empresas com os governos.

Com base nesses resultados de diagnóstico, o Governo Eletrônico identifica como ações estratégicas:

O Estabelecimentos de um portifólio de e-serviços relacionados a direitos e obrigações que incremente a prestação de serviços por meios eletrônicos, o controle social e a participação popular;

A instituição de uma Agenda de Serviços Interoperáveis para cidadãos e empresas que integre governos locais, estaduais e Governo Federal;

A consolidação de um plano nacional para a implantação de serviços de Governo Eletrônico;

A análise de melhores práticas de Governo Eletrônico em âmbito nacional com indicadores públicos de qualidade. UNIVERSIDADE DO SUL DE SANTA CATARINA. Governo Eletrônico: estratégias de elaboração, desenvolvimento e implementação de projetos. $2^{\underline{a}}$ edição. Palhoça: Unisulvirtual, 2008. p. 144. 


\section{b) Programa Brasileiro de Inclusão Digital}

O governo brasileiro tem como uma das prerrogativas que a inclusão social é um processo indissociável do Governo Eletrônico.

A inclusão digital é pode ser entendida como acesso universal ao uso das tecnologias de informação e comunicação e ususfruto universal dos benefícios trazidos por essas tecnologias. A inclusão digital bem como a produção de conhecimento são fatores fundamentais para o desenvolvimento econômico, cultural, político e social do país. In: UNIVERSIDADE DO SUL DE SANTA CATARINA. Governo Eletrônico: estratégias de elaboração, desenvolvimento e implementação de projetos. $2^{\underline{a}}$ edição. Palhoça: Unisulvirtual, 2008. p. 144 e 145.

Este programa visa promover:

- O acesso às tecnologias da informação e comunicação entre as classes C,D, e E da população;

- A integração e coordenação das ações de inclusão digital;

- A indução e o fomento para a criação de espaços públicos de acesso comunitário por governos municipais, estaduais, iniciativa privada e sociedade civil;

- Estímulo à política pública de inclusão digital.

Em função das condições atuais do Brasil, a política de Governo Eletrônico "não promove o acesso individual a internet e sim a criação de uma infra-estrutura pública para ampliar o acesso à rede mundial de computadores aos setores impedidos de ter acesso individual". In: UNIVERSIDADE DO SUL DE SANTA CATARINA. Governo Eletrônico: estratégias de elaboração, desenvolvimento e implementação de projetos. $2^{a}$ edição. Palhoça: Unisulvirtual, 2008. p. 145.

\section{c) Padrões de Interoperabilidade (e-PING)}

A interoperabilidade pode ser definida como:

Para o Comitê Executivo do Governo Eletrônico - CEGE, interoperabilidade pode ser entendida como sendo a soma de fatores como a integração de sistemas, a integração de redes, a troca de dados entre sistemas e a definição de tecnologia, considerando também, a existência de um legado de sistemas, de plataformas de hardware e sofware instaladas. UNIVERSIDADE DO SUL DE SANTA CATARINA. Governo Eletrônico: estratégias de elaboração, desenvolvimento e implementação de projetos. $2^{\mathrm{a}}$ edição. Palhoça: Unisulvirtual, 2008. p. 145.

Ou ainda:

A arquitetura e-PING - Padrões de Interoperabilidade de Governo Eletrônico

- define um conjunto mínimo de premissas, políticas e especificações 


\begin{abstract}
técnicas que regulamentam a utilização de tecnologia de informação e comunicação na interoperabilidade de serviços de governo eletrônico, estabelecendo as condições de interação com os demais poderes e esferas de governo e com a sociedade em geral. (Disponível em: <http://www.governoeletronico.gov.br/acoes-e-projetos/e-ping-padroes-deinteroperabilidade>. Acesso em: 16 mar. 2009.)
\end{abstract}

As áreas cobertas pela arquitetura e-PING estão segmentadas em:

- interconexão;

- segurança;

- meios de acesso;

- organização e intercâmbio de informações;

- áreas de integração para Governo Eletrônico.

E cada um destes segmentos contém um conjunto de políticas técnicas de aplicações.

O Brasil está num processo de padronização e conectividade, com uma forte política para a integração de todos os serviços do governo, nas esferas federal, estadual e municipal e também de inclusão digital, através da implantação de locais de acesso à internet em todo o país.

O Governo brasileiro enfatiza a política de Governo Eletrônico como sendo um facilitador da economia, referindo-se aos portais de compra e contratações entre outros serviços públicos on-line e também como suporte da democracia, referindo-se aos mecanismos de fiscalização da gestão pública.

\title{
3.2.3. Os Pré Requisitos do Governo Eletrônico
}

Os projetos de maior impacto que existem hoje em vários países, partiram de um conjunto de iniciativas envolvendo todos os organismos que formam o Estado. A presença do órgão público na Internet é apenas uma das expressões do Governo Eletrônico, que pode ter outras aplicações como votação eletrônica, redes intra e interinstitucionais, compartilhamento de bases de dados entre diferentes instâncias de governo, etc.

\section{a) Informatização}

O primeiro beneficiário deste processo é o funcionário público e os tomadores de decisão que usam as ferramentas das tecnologias da informação e comunicação a favor da sua gestão. Em seguida, outras agências públicas que compartilham da mesma base de dados e principalmente os cidadãos, cujo acesso à informação pública, vem nos últimos anos sendo garantidas por leis e a internet é o meio mais eficiente para disponibilizar essa informação. 
Outras considerações importantes sobre a informatização pública, segundo Boeing (2008):

- Quando a informação pública fica disponível pela Internet, pode ser chamada de conteúdo $\mathrm{O}$ governo é um dos maiores geradores de conteúdo;

- Tornar disponível a informação pública ou conteúdos gerados pelo Estado, não significa que tenha havido uma mudança organizacional ou reforma institucional;

- A informatização de uma agência pública converte-se em serviço para o cidadão quando se encontra disponível e útil. Nem toda informação gerada precisa ser publicada, pois poderá causar confusão, dificuldades de busca e efeitos opostos aos desejados;

- Estima-se que a redução nos custos administrativos seja em torno de 50\% quando há a transição de documentos em papel para a internet, sem levar em conta economias adicionais de dinheiro, tempo e deslocamento do cidadão. In: UNIVERSIDADE DO SUL DE SANTA CATARINA. Governo Eletrônico: estratégias de elaboração, desenvolvimento e implementação de projetos. $2^{\underline{a}}$ edição. Palhoça: Unisulvirtual, 2008. p. 137.

\section{b) Mudanças Organizacionais}

No principal postulado do National Performance Review do governo americano: "criar um governo que trabalhe menos e custe menos", focava-se primeiro no redesenho dos fluxos dos processos burocráticos para melhorar os serviços, incorporando-se as TICs para aprimorar a capacidade do governo, conforme Matuzawa (2008):

"Este processo de informatização não reestrutura os processos governamentais, mas a tecnologia oferece a oportunidade de produzir mudanças profundas na administração do Estado." In: UNIVERSIDADE DO SUL DE SANTA CATARINA. Governo Eletrônico: estratégias de elaboração, desenvolvimento e implementação de projetos. $2^{\underline{a}}$ edição. Palhoça: Unisulvirtual, 2008. p. 86.

O simples fato de uma quantidade de tarefas passarem a serem realizadas por computador, provocou uma redistribuição de funções, racionalização e consequente desburocratização de serviços ligados à informação.

c) Reforma Institucional

O modelo de Estado caracterizado por uma forma vertical, com forte hierarquia, tendência centralizadora e baixa colaboração entre suas instituições precisam ser revistos. 
"A integração das TIC ao Estado e o crescente uso da internet estão introduzindo mudanças de fato ou não previstas nas instituições. Isso quer dizer que as consequências e transformações que causam o uso das TIC nos processos governamentais ou a presença de uma agência pública na internet são, na maioria das vezes, inesperadas e profundas. Entretanto, em muitas ocasiões, o uso da internet e das TIC é incorporado para manter o status quo e não como uma ferramenta de transformação institucional. Nesses casos, o nível de transformação é pequeno e mantêm-se os elementos de ineficiência e obsoletismo que supostamente deveriam mudar." In: UNIVERSIDADE DO SUL DE SANTA CATARINA. Governo Eletrônico: estratégias de elaboração, desenvolvimento e implementação de projetos. $2^{\mathrm{a}}$ edição. Palhoça: Unisulvirtual, 2008. p. 91.

Os governos vêm se preocupando muito com serviços prestados aos cidadãos no Governo Eletrônico, mas precisam primeiro pensar na reorganização e reestruturação das relações entre intituições, para que estes serviços prestados avancem cada vez mais.

Por exemplo, pode-se citar a abertura de uma empresa através de trâmites on-line. O aspecto principal não é o site onde o cidadão realizará este serviço, mas os arranjos entre os órgãos envolvidos no registro, autorização, controles, etc, até a formação da nova empresa.

O Governo Brasileiro tem um considerável avanço nesta área de interoperabilidade das agências públicas. Existe um documento chamado E-Ping que é o padrão técnico de interoperabilidade brasileiro, objetivando a integração das informações e dos serviços governamentais.

\subsubsection{A Implantação de um Governo Eletrônico Nacional}

Conforme citado anteriormente, é muito importante o comprometimento dos altos escalões de governo para a implantação de um Governo Eletrônico em qualquer país. As estratégias devem fazer parte de uma política nacional de desenvolvimento, uma espécie de Agência da Informação, sendo definido o tipo da organização (grupo de trabalho, unidade técnica) o nível de autoridade (determinado por leis e regulamentos) e os níveis de autonomia financeira.(entidade negociadora ou administradora de recursos orçamentários).

Também é necessário citar os principais elementos que compõem a elaboração de um documento contendo uma estratégia de implantação do e-gov:

- Diagnóstico da situação atual de inserção e alcance das TIC na população e nos governos:

- Visão e objetivos a serem alcançados;

- Contexto legal e regulador; 
- Estabelecimento de padrões básicos;

- Política de acesso às TIC;

- Parâmetros de seleção de projetos;

- Identificação de benefícios e políticas de difusão;

- Grupos de trabalho;

- Orientações oficiais;

- Esquemas de financiamento;

- Esquemas de participação;

- Órgão de coordenação.

Abaixo, exemplos destes Conselhos/Comitês Nacionais para 0 desenvolvimento do governo eletrônico na América Latina:

\begin{tabular}{|c|c|c|}
\hline País & Nome & Ligado ao Órgão \\
\hline Brasil & $\begin{array}{l}\text { Comitê Executivo do Governo } \\
\text { Eletrônico - CEGE }\end{array}$ & $\begin{array}{l}\text { Conselho de Governo e Casa Civil } \\
\text { da Presidência da República }\end{array}$ \\
\hline Paraguai & $\begin{array}{ll}\text { Conselho } & \text { Coordenador } \\
\text { SOCINFO-PY } & \end{array}$ & Presidência da República \\
\hline Uruguai & $\begin{array}{l}\text { Comitê Nacional para a } \\
\text { Sociedade da Informação }\end{array}$ & Presidência da República \\
\hline Bolívia & $\begin{array}{l}\text { Agência para Desenvolvimento } \\
\text { da Sociedade da Informação }\end{array}$ & Vice-Presidência da República \\
\hline Colômbia & Agência da Conectividade & Vice-Presidência da República \\
\hline Costa Rica & $\begin{array}{l}\text { Direção Nacional de Governo } \\
\text { Digital }\end{array}$ & Ministério da Presidência \\
\hline Chile & $\begin{array}{l}\text { Comitê de Ministros de } \\
\text { Tecnologias de Informação e } \\
\text { Comunicação }\end{array}$ & Conselho de Ministros \\
\hline Venezuela & $\begin{array}{l}\text { Centro Nacional de Tecnologias } \\
\text { da Informação }\end{array}$ & Ministério de Ciência e Tecnologia \\
\hline
\end{tabular}


Quadro 04 - Conselhos ou Comitês Nacionais de Desenvolvimento do Governo Eletrônico na América Latina - Fonte: Organização dos Estados Americanos OEA / Secretaria Executiva para o Desenvolvimento Integral - SEDI - 2008

Para que as estratégias de governo eletrônico obtenham sucesso em suas propostas é necessário antes de empreender projetos muito ambiciosos, dar passos pequenos, focando certos serviços prioritários e depois ir crescendo através das metas e objetivos estabelecidos.

Sem dúvida a área de maior impacto do governo eletrônico é a internet, porém seu acesso ainda é caro e limitado, a expansão da telefonia celular com acesso a Internet e a diminuição do custo dos computadores, vai ao longo do tempo diminuir a exclusão digital.

\subsubsection{A Importância das Agências de Socialização da Informação - ASI}

O Estado deve facilitar a interação entre as suas diversas entidades governamentais e trabalhar melhor através da colaboração interinstitucional, fornecendo cada vez mais serviços aos cidadãos. Para articular toda a informação e distribuí-la através das várias entidades de governo, as ASls cumprem seu papel de disponibilizar infraestrutura, rede de comunicação de dados, voz e imagem para viabilizarem as soluções em governo eletrônico.

Essas entidades atuam na busca da modernização administrativa, aliada à qualidade e produtividade dos serviços que os governos estaduais prestam à sociedade. Procuram a constante reciclagem tecnológica apresentando as melhores soluções ao administrador público, contribuindo na melhora dos serviços prestados à comunidade.

As agências de socialização da informação estão presentes em todo o território nacional, umas mais avançadas, outras menos, alguns municípios como o de São Paulo, contam com uma ASI própria, devido seus números superlativos. A seguir uma relação delas no país e algumas de suas atuações básicas.

\begin{tabular}{|l|l|l|l|}
\hline Estado & Nome da Agência & Natureza Jurídica & Sítio \\
\hline Acre & $\begin{array}{l}\text { SGA - Secretaria de Gestão } \\
\text { Administrativa }\end{array}$ & $\begin{array}{l}\text { Administração } \\
\text { Direta }\end{array}$ & www.gestão.ac.gov.br \\
\hline Alagoas & $\begin{array}{l}\text { ITEC - Instituto de Tecnologia em } \\
\text { Informática e Informação do Estado de } \\
\text { Alagoas }\end{array}$ & Autarquia & $\begin{array}{l}\text { www.itec.al.gov.br } \\
\text { movel.al.gov.br }\end{array}$ \\
\hline Amapá & $\begin{array}{l}\text { PRODAP - Processamento de Dados } \\
\text { do Amapá }\end{array}$ & Autarquia Estadual & $\underline{\text { www.prodap.ap.gov.br }}$ \\
\hline Amazonas & $\begin{array}{l}\text { PRODAM - Processamento de Dados } \\
\text { Amazonas S/A }\end{array}$ & $\begin{array}{l}\text { Pessoa Jurídica de } \\
\text { Direito Privado }\end{array}$ & $\underline{\text { www.prodam.com.br }}$ \\
\hline Bahia & $\begin{array}{l}\text { PRODEB - Companhia de } \\
\text { Processamento de Dados do Estado da } \\
\text { Bahia }\end{array}$ & $\begin{array}{l}\text { Pessoa Jurídica de } \\
\text { Direito Privado }\end{array}$ & $\underline{\text { www.prodeb.gov.br }}$ \\
\hline
\end{tabular}




\begin{tabular}{|c|c|c|c|}
\hline Ceará & $\begin{array}{l}\text { ETICE - Empresa de Tecnologia da } \\
\text { Informação do Ceará }\end{array}$ & $\begin{array}{l}\text { Empresa Pública de } \\
\text { Direito Privado }\end{array}$ & www.etice.ce.gov.br \\
\hline Espírito Santo & $\begin{array}{l}\text { PRODEST - Instituto de Tecnologia da } \\
\text { Informação e Comunicação do Estado } \\
\text { do Espírito Santo }\end{array}$ & Autarquia Estadual & www.iti.es.gov.br \\
\hline Goiás & $\begin{array}{l}\text { SGT - Superintendência de Gestão de } \\
\text { Tecnologia da Informação } \\
\text { SEFAZ - Secretaria da Fazenda do } \\
\text { Estado de Goiás }\end{array}$ & $\begin{array}{l}\text { Administração } \\
\text { Direta }\end{array}$ & www.sefaz..go.gov.br \\
\hline Maranhão & $\begin{array}{l}\text { SEATI- Secretaria Adjunta de } \\
\text { Tecnologia da Informação e Integração } \\
\text { SEPLAN- Secretaria de Planejamento } \\
\text { Orçamento e Gestão }\end{array}$ & $\begin{array}{l}\text { Jurídica de Direito } \\
\text { Público }\end{array}$ & www.seati.ma.gov.br \\
\hline Mato Grosso & $\begin{array}{l}\text { CEPROMAT - Centro de } \\
\text { Processamento de Dados do Estado } \\
\text { do MT }\end{array}$ & $\begin{array}{l}\text { Pessoa Jurídica de } \\
\text { Direito Privado }\end{array}$ & www.cepromat.mt.gov.br \\
\hline $\begin{array}{l}\text { Mato Grosso } \\
\text { do Sul }\end{array}$ & $\begin{array}{l}\text { SGI - Superintendência de Gestão da } \\
\text { Informação } \\
\text { Secretaria de Estado de Fazenda }\end{array}$ & $\begin{array}{l}\text { Direito Público } \\
\text { Interno }\end{array}$ & www.sgi.ms.gov.br \\
\hline Minas Gerais & $\begin{array}{l}\text { PRODEMGE - Companhia de } \\
\text { Tecnologia da Informação do Estado de } \\
\text { Minas Gerais }\end{array}$ & $\begin{array}{l}\text { Pessoa Jurídica de } \\
\text { Direito Privado }\end{array}$ & www.prodemge.gov.br \\
\hline Pará & $\begin{array}{l}\text { PRODEPA - Processamento de Dados } \\
\text { do Estado do Pará }\end{array}$ & $\begin{array}{l}\text { Pessoa Jurídica de } \\
\text { Direito Privado }\end{array}$ & www.prodepa.gov.br \\
\hline Paraíba & $\begin{array}{l}\text { CODATA - Companhia de } \\
\text { Processamento de Dados da Paraíba }\end{array}$ & $\begin{array}{l}\text { Pessoa Jurídica de } \\
\text { Direito Privado }\end{array}$ & www.codata.pb.gov.br \\
\hline Paraná & $\begin{array}{l}\text { CELEPAR - Companhia de Informática } \\
\text { do Paraná }\end{array}$ & $\begin{array}{l}\text { Pessoa Jurídica de } \\
\text { Direito Privado }\end{array}$ & www.celepar.pr.gov.br \\
\hline Pernambuco & $\begin{array}{l}\text { ATI - Agência Estadual de Tecnologia } \\
\text { da Informação }\end{array}$ & Autarquia & www.ati.pe.gov.br \\
\hline Piauí & $\begin{array}{l}\text { ATI - Agência de Tecnologia da } \\
\text { Informação do Estado do Piauí }\end{array}$ & $\begin{array}{l}\text { Pessoa Jurídica de } \\
\text { Direito Privado }\end{array}$ & www.ati.pi.gov.br \\
\hline Rio de Janeiro & $\begin{array}{l}\text { PRODERJ - Centro de Tecnologia da } \\
\text { Informação e Comunicação do Estado } \\
\text { do Rio de Janeiro }\end{array}$ & Autarquia & www.proderi.ri.gov,br \\
\hline $\begin{array}{l}\text { Rio Grande do } \\
\text { Norte }\end{array}$ & $\begin{array}{l}\text { COTIC - Coordenadoria de Operações } \\
\text { de Tecnologia da Informarção e } \\
\text { Comunicação } \\
\text { SEARH - Secretaria de Estado da } \\
\text { Administração e dos Recursos } \\
\text { Humanos }\end{array}$ & $\begin{array}{l}\text { Pessoa Jurídica de } \\
\text { Direito Público }\end{array}$ & www.cotic.rn.gov.br \\
\hline $\begin{array}{l}\text { Rio Grande do } \\
\text { Sul }\end{array}$ & $\begin{array}{l}\text { PROCERGS - Companhia de } \\
\text { Processamento de Dados do Estado do } \\
\text { Rio Grande do Sul }\end{array}$ & $\begin{array}{l}\text { Pessoa Jurídica de } \\
\text { Direito Privado }\end{array}$ & www.procergs.com.br \\
\hline Roraima & $\begin{array}{l}\text { SETI - Secretaria de Estado } \\
\text { Extraordinária de Tecnologia da } \\
\text { Informação }\end{array}$ & $\begin{array}{l}\text { Pessoa Jurídica de } \\
\text { Direito Público }\end{array}$ & www.cti.rr.gov.br \\
\hline Santa Catarina & $\begin{array}{l}\text { CIASC - Centro de Informática e } \\
\text { Automação do Estado de SC S/A }\end{array}$ & $\begin{array}{l}\text { Pessoa Jurídica de } \\
\text { Direito Privado }\end{array}$ & www.ciasc.gov.br \\
\hline São Paulo & $\begin{array}{l}\text { PRODESP - Companhia de } \\
\text { Processamento de Dados do Estado de } \\
\text { São Paulo }\end{array}$ & $\begin{array}{l}\text { Pessoa Jurídica de } \\
\text { Direito Privado }\end{array}$ & www.prodesp.sp.gov.br \\
\hline Sergipe & $\begin{array}{l}\text { EMGETIS - Empresa Sergipana de } \\
\text { Tecnologia da Informação }\end{array}$ & Autarquia & letis.se.gov.br \\
\hline Tocantins & $\begin{array}{l}\text { SI - Superintendência de Informática do } \\
\text { Tocantins }\end{array}$ & $\begin{array}{l}\text { Pessoa Juridica de } \\
\text { Direito Público }\end{array}$ & www.si \\
\hline
\end{tabular}

Quadro 05 - Agências Estaduais de Socialização da Informação - Fonte: Associação Brasileira de Entidades Estaduais de Tecnologia da Informação e Comunicação - ABEETIC - 2009

Exemplos da atuação das ASls: 


\section{Governo do Estado do Rio de Janeiro}

\section{www.proderj.rj.gov.br}

O PRODERJ - Centro de Tecnologia da Informação e Comunicação do Estado do Rio de Janeiro - autarquia vinculada à Secretaria de Estado da Casa Civil é o órgão gestor de Tecnologia da Informação e Comunicação (TIC) do Governo do Estado, desempenhando o importante papel de propor diretrizes e orientações técnicas voltadas para o estabelecimento da política de TIC no âmbito da administração pública estadual.

Ao incorporar as novas funções de integrador e homologador de soluções, gerador de normas e padrões e disseminador de novas tecnologias para a informática pública, o PRODERJ evoluiu, deixando de ser apenas um grande bureau de processamento de dados e se tornando, de forma cada vez mais efetiva, o responsável pelos sistemas corporativos e pela gestão da Rede Governo, provendo serviços de Internet e atividades afins para o Governo do Estado. Ao longo de sua existência, o foco principal em todas as ações empreendidas pelo PRODERJ tem sido o de colocar a " Tecnologia a Serviço do Cidadão ".

Dentre suas atribuições se encontram:

- Propor ao Governo do Estado as diretrizes e orientações técnicas para o estabelecimento da Política de Tecnologia da Informação - TIC, assim como normas e padrões a serem adotados nesta área;

Atuar como agente central na oferta de todos os serviços e infra-estrutura de Tecnologia da Informação e Comunicação corporativa necessários no paradigma atual;

- Projetar, desenvolver, sediar, manter e operar as bases de dados corporativas operacionais e de suporte à decisão, de sistemas sediados no Centro de Tecnologia da Informação e Comunicação do Estado do Rio de Janeiro, e de outros geridos pelos órgãos da administração direta e indireta cuja integração seja necessária para uso corporativo do Governo do Estado;

- Fornecer informações estratégicas para subsidiar a Chefia do Poder Executivo no planejamento e execução de políticas públicas;

- Administrar, manter e operar a infra-estrutura de comunicações, representada pela Rede Governo, atuando como ponto focal de convergência das diversas redes locais dos órgãos do Estado, oferecendo conectividade global a todas as áreas de Tecnologia de Informação e Comunicação do Governo, incluindo os equipamentos corporativos centralizados;

. Planejar e coordenar a implantação de uma solução de rede multisserviço 
que suporte tráfego integrado de voz, dados e imagens, para as diversas demandas de comunicações no âmbito do governo estadual, inclusive telefonia, com capilaridade e capacidade adequadas para evitar a duplicação de esforços na criação de subrredes paralelas distintas;

- Prover serviços de Internet aos órgãos da administração estadual, tais como correio eletrônico, consultoria, desenvolvimento e hospedagem de páginas, portais, intranets e extranets;

Além de outras iniciativas, como facilitar os programas de inclusão digital, etc. Para a lista completa entre em http://www.proderj.rj.gov.br/atribuicoes.asp

Projetos que merecem destaque:

É a Internet Comunitária - www.internetcomunitaria.rj.gov.br, projeto voltado para o cidadão, e que tem crescido bastante nos últimos anos. Esse visa a inclusão digital através da construção de laboratórios de informática em diversos pontos do estado, onde são oferecidos à população treinamentos gratuitos de alfabetização digital, acesso à web em banda larga e diversos serviços de governo eletrônico.

Na esfera G2G, a atuação se dá pelo Portal do Governo do Rio. Assim como para o cidadão, o portal é muito mais informativo que interativo. Nele se tem acesso a licitações, legislações etc.

Na esfera G2B, destacam-se os sites voltados para empreeendedores CODIN - www.codin.rj.gov.br e o InvesteRio - www.investerio.com.br. ${ }^{5}$

Grupo de usuário: GTG Estágio: transacional

Quadro 06 - Site da Proderj - Governo do Estado do Rio de Janeiro

\section{Prefeitura do Município de São Paulo}

www.prodam.sp.gov.br

A PRODAM - Empresa de Tecnologia da Informação e Comunicação do Município de São Paulo, criada em 1971, é responsável pelo processamento de dados das diversas secretarias e empresas da Prefeitura de São Paulo. (todas as secretarias, Autarquias Hospitalares, Emurb - Empresa Municipal de Urbanização, SPTuris, São Paulo Transportes) e também o Tribunal de Contas do Município e a Câmara Municipal. Desempenha o papel de prover à Prefeitura da Cidade de São Paulo soluções de TIC para a melhoria do desempenho da administração em diferenciadas áreas.

Destaque: Acessibilidade a deficientes físicos,

\footnotetext{
${ }^{5}$ Texto fornecido por Nathalia Correa Khayat, via internet em 03/03/2009. Informação pessoal.
} 
A Prodam "tendo sido uma das pioneiras na América Latina no uso da informática na administração municipal e no emprego de pessoas com deficiência visual como profissionais em processamento de dados. Emprega deficientes desde 1973, que prestam serviço nas mais diferentes áreas como: programação, desenvolvimento de sistemas, suporte técnico e administrativo. Trabalham em período integral, participando direta e ativamente do desenvolvimento, implantação e processamento de sistemas utilizados por toda a administração de São Paulo."

"Em outubro de 1998, a PRODAM inaugurou uma sala com 12 microcomputadores adaptados com sintetizadores de voz. Instrutores e monitores foram capacitados pelos próprios técnicos deficientes visuais da empresa. Eram ministrados cursos de microinformática totalmente gratuitos para deficientes visuais de todo o País."

"Com aquela iniciativa, a PRODAM tornou-se a primeira empresa de informática de administração pública a possuir uma sala preparada para ministrar cursos totalmente adaptados para cegos."

Outros dois projetos que merecem ser citados:

SLEA (Sistema de Licenciamento Eletrônico de Atividades): "O SLEA faz parte do Programa São Paulo Mais Fácil, criado pela Secretaria Especial de Desburocratização (SED), e vem facilitando a vida do pequeno empresário que precisa de um Auto de Licença de Funcionamento para o seu negócio."

"Ambientado no website da SED, o sistema permite que o cidadão faça o requerimento e imprima pela Internet o alvará de funcionamento para o seu estabelecimento em um prazo mínimo de até quinze minutos, desde que o imóvel esteja totalmente regularizado e que sejam observadas as exigências legais complementares."

De Olho na Obra: "O novo sistema pode ser acessado pelo Portal da Prefeitura e tem por objetivo oferecer possibilidades para que o cidadão verifique se as obras que estão sendo executadas na Cidade de São Paulo obedecem ou não à legislação vigente."

"A ação foi idealizada pela Secretaria Especial de Desburocratização (SED) e visa dar transparência a todos os alvarás de construção ou reformas emitidos pela Prefeitura. Assim, as construções, reconstruções e reformas de imóveis agora já podem ser fiscalizadas pelos próprios munícipes."

"Estão disponíveis no sistema todos os alvarás expedidos na capital desde 1997, com os dados básicos das respectivas construções e reformas. Desta forma, 
qualquer cidadão pode agora ajudar a administração pública a fiscalizar qualquer obra na Cidade."

Pontos Críticos: A informatização da rede de saúde ainda não está terminada e poderia ter um banco de dados do histórico de saúde dos munícipes interligado a prontuários médicos digitais. Agilizaria consultas, dimensionaria a necessidade de remédios, entre outros benefícios.

\section{Grupo de usuário: GTG Estágio: transacional}

Quadro 07 - Site da Prodam - Prefeitura do Município de São Paulo -.Disponível em: http://www.prodam.sp.gov.br. Acesso em 18 mar. 2009.

\subsection{O GOVERNO ELETRÔNICO NO MUNDO}

A Rede Online das Nações Unidas para Serviço Público e Administração (Unpan, da sigla em inglês) publicou em 2008, um relatório sobre serviços de governo eletrônico em todo o mundo. O documento UNPAN 028607 está disponível no site http://unpan1.un.org. O estudo, leva em consideração a disponibilidade de serviços públicos na Internet bem como a facilidade de navegação, obtenção de informação e serviços disponíveis nas páginas dos governos. Além de dados sobre a inclusão digital, classifica os 191 países membros da ONU de acordo com índices de acesso a sites, infra-estrutura de telecomunicações e recursos humanos. Quanto mais próximo de um, mais desenvolvido é o país neste critério. A seguir o ranking dos primeiros 70 países e em seguida o ranking por região.

A média mundial do índice global de governo eletrônico continua a aumentar, à medida que mais países investem em recursos no desenvolvimento de sites que são informativos. A maior parte dos países já possuem políticas específicas para o desenvolvimento do governo eletrônico. A diferença entre os países em desenvolvimento e os desenvolvidos está relacionado a informação presente em sites, a consulta aos cidadãos e a tomada de decisão por este novo canal de comunicação do governo.

No relatório de E-gov 2008, a Suécia ficou com o primeiro lugar. Os países escandinavos tomaram as três primeiras posições, com a Dinamarca e a Noruega em segundo e terceiro lugar respectivamente. Os Estados Unidos entraram no quarto lugar.

No ranking deste ano, os países europeus representam $70 \%$ dos primeiros 35 países. Os países asiáticos compõem $20 \%$ dos 35 e a América do Norte e Oceania $5 \%$ por cento. Os países europeus, como um grupo, têm investido fortemente na 
implantação de infra-estrutura de banda larga, juntamente com um aumento na implementação de aplicações de governo eletrônico para os seus cidadãos.

Os países europeus perfazem nove dos dez maiores países em assinantes de banda larga por cem habitantes, com a Dinamarca, Países Baixos e Islândia sendo os três principais países, segundo o relatório.

\begin{tabular}{|c|c|c|}
\hline Posição & País & Índice e-gov \\
\hline 1 & Suécia & 0.9157 \\
\hline 2 & Dinamarca & 0.9134 \\
\hline 3 & Noruega & 0.8921 \\
\hline 4 & Estados Unidos & 0.8644 \\
\hline 5 & Holanda & 0.8631 \\
\hline 6 & República da Coréia & 0.8317 \\
\hline 7 & Canadá & 0.8172 \\
\hline 8 & Austrália & 0.8108 \\
\hline 9 & França & 0.8038 \\
\hline 10 & Reino Unido & 0.7872 \\
\hline 11 & Japão & 0.7703 \\
\hline 12 & Suíça & 0.7626 \\
\hline 13 & Estônia & 0.7600 \\
\hline 14 & Luxemburgo & 0.7512 \\
\hline 15 & Finlândia & 0.7488 \\
\hline 16 & Áustria & 0.7428 \\
\hline 17 & Israel & 0.7393 \\
\hline 18 & Nova Zelândia & 0.7392 \\
\hline 19 & Irlanda & 0.7296 \\
\hline 20 & Espanha & 0.7228 \\
\hline 21 & Islândia & 0.7176 \\
\hline 22 & Alemanha & 0.7136 \\
\hline 23 & Singapura & 0.7009 \\
\hline
\end{tabular}




\begin{tabular}{|l|l|l|}
\hline 24 & Bélgica & 0.6779 \\
\hline 25 & República Checa & 0.6696 \\
\hline 26 & Eslovênia & 0.6681 \\
\hline 27 & Itália & 0.6680 \\
\hline 28 & Lituânia & 0.6617 \\
\hline 29 & Malta & 0.6582 \\
\hline 30 & Hungria & 0.6485 \\
\hline 31 & Portugal & 0.6479 \\
\hline 32 & Emirados Árabes & 0.6301 \\
\hline 33 & Polônia & 0.6117 \\
\hline 34 & Malásia & 0.6063 \\
\hline 35 & Chipre & 0.6019 \\
\hline
\end{tabular}

Quadro 08 - Posição Mundial de Desenvolvimento de Governo Eletrônico entre Países do 1ำ ao $35^{\circ}$ lugar

Fonte - Relatório da ONU: "United Nations e-goverment survey 2008 - From egovernment to connected governance". Disponível em: <http://unpan1.un.org/ intradoc/groups/public/documents/UN/UNPAN 028607.pdf> Acesso em 03 abr. 2009.

Nota-se que não existem países da África, Caribe, Ásia Central, Sul da Ásia e América do Sul nos 35 primeiros lugares. A ONU atribui esse fato ao alto custo de implantação de infra-estrutura para a inclusão digital, que ficam em segundo plano, porque além de dificuldades de implementação de políticas de governo eletrônico, as questões sociais necessitam de recursos mais urgentes, como saúde, educação e empregos.

A seguir os próximos 35 colocados:

\begin{tabular}{|l|l|l|}
\hline Posição & País & Índice e-gov \\
\hline 36 & Latvia & 0,5944 \\
\hline 37 & México & 0.5893 \\
\hline 38 & Eslováquia & 0.5889 \\
\hline 39 & Argentina & 0.5844 \\
\hline 40 & Chile & 0.5819 \\
\hline
\end{tabular}




\begin{tabular}{|c|c|c|}
\hline 41 & Ucrânia & 0.5728 \\
\hline 42 & Bahrein & 0.5723 \\
\hline 43 & Bulgária & 0.5719 \\
\hline 44 & Grécia & 0.5718 \\
\hline 45 & Brasil & 0.5679 \\
\hline 46 & Barbados & 0.5667 \\
\hline 47 & Croácia & 0.5650 \\
\hline 48 & Uruguai & 0.5645 \\
\hline 49 & Liechtenstein & 0.5486 \\
\hline 50 & Jordânia & 0.5480 \\
\hline 51 & Romênia & 0.5383 \\
\hline 52 & Colômbia & 0.5317 \\
\hline 53 & Catar & 0.5314 \\
\hline 54 & Trindade e Tobago & 0.5307 \\
\hline 55 & Peru & 0.5252 \\
\hline 56 & Belarus & 0.5213 \\
\hline 57 & Kuwait & 0.5202 \\
\hline 58 & Andorra & 0.5175 \\
\hline 59 & Costa Rica & 0.5144 \\
\hline 60 & Federação Russa & 0.5120 \\
\hline 61 & África do Sul & 0.5115 \\
\hline 62 & Venezuela & 0.5095 \\
\hline 63 & Maurício & 0.5086 \\
\hline 64 & Tailândia & 0.5031 \\
\hline 65 & China & 0.5017 \\
\hline 66 & Filipinas & 0.5002 \\
\hline 67 & El Salvador & 0.4974 \\
\hline 68 & República Dominicana & 0.4943 \\
\hline
\end{tabular}




\begin{tabular}{|l|l|l|}
\hline 69 & Seychelles & 0.4942 \\
\hline 70 & Arábia Saudita & 0.4935 \\
\hline
\end{tabular}

Quadro 09 - Posição Mundial de Desenvolvimento de Governo Eletrônico entre Países do 36ํㅡㄴ ao $70^{\circ}$ lugar

Fonte - Relatório da ONU: "United Nations e-goverment survey 2008 - From egovernment to connected governance". Disponível em: <http://unpan1.un.org/ intradoc/groups/public/documents/UN/UNPAN 028607.pdf> Acesso em 03 abr. 2009.

Uma outra tabela com divisão de índices por região, apresenta uma comparação entre os continentes.

Ranking e-gov por região:

\begin{tabular}{|l|l|l|l|l|l|}
\hline Região & $\mathbf{2 0 0 8}$ & $\mathbf{2 0 0 5}$ & Região & $\mathbf{2 0 0 8}$ & $\mathbf{2 0 0 5}$ \\
\hline & & & & & \\
\hline África & & & Américas & & \\
\hline África Central & 0.2530 & 0.2397 & Caribe & 04480 & 0.4282 \\
\hline África Oriental & 0.2879 & 0.2836 & América Central & 0.4604 & 0.4255 \\
\hline Norte da África & 0.3403 & 0.3098 & América do Norte & 0.8408 & 0.8744 \\
\hline Sul da África & 0.3893 & 0.3886 & América do Sul & 0.5072 & 0.4901 \\
\hline Oeste da Africa & 0.2110 & 0.1930 & & & \\
\hline & & & & & \\
\hline Ásia & & & Europa & & \\
\hline Ásia Central & 0.3881 & 0.4173 & Europa Oriental & 0.5689 & 0.5556 \\
\hline Ásia Oriental & 0.6443 & 0.6392 & Norte da Europa & 0.7721 & 0.7751 \\
\hline Sul da Ásia & 0.3395 & 0.3126 & Sul da Europa & 0.5642 & 0.4654 \\
\hline Sudeste da Ásia & 0.4290 & 0.4388 & Europa Ocidental & 0.7329 & 0.6248 \\
\hline Ásia Ocidental & 0.4857 & 0.4384 & & & \\
\hline Média mundial & $\mathbf{0 . 4 5 1 4}$ & $\mathbf{0 . 4 2 6 7}$ & & & \\
\hline & 0.4338 & 0.2888 & & & \\
\hline Oceania & & & & & \\
\hline & & & & & \\
\hline
\end{tabular}

Quadro 10 - Posição Mundial de Desenvolvimento de Governo Eletrônico por Regiões 
Fonte - Relatório da ONU: "United Nations e-goverment survey 2008 - From egovernment to connected governance". Disponível em: <http://unpan1.un.org/ intradoc/groups/public/documents/UN/UNPAN 028607.pdf> Acesso em 03 abr. 2009.

Na região asiática, há uma grande diferença entre a Ásia Oriental e as outras regiões. Nota-se que as regiões de Ásia Central e do Sul estão abaixo da média mundial. Na região européia, há uma diferença significativa entre Europa do Norte e Ocidental com relação a Europa Oriental e Sul. Destaca-se também que a Europa é a única região que tem todas suas subrregiões acima da média mundial.

\subsubsection{O Governo Eletrônico na América Latina}

Como em todas as áreas de atuação de um governo, a conjuntura econômica, política e social de um país influência também o governo eletrônico. Os países da América Latina enfrentam, de maneira geral, os mesmos problemas: pobreza, baixa escolaridade, corrupção, entre outros. Passaram pelas mesmas fases de informatização do Estado desde os anos 80:

- o advento do computador nas repartições públicas;

- as TICs ligando os processos internos e auxiliando na troca de dados;

- e a presença da internet como forma de relacionamento com os cidadãos, empresas e governos.

Porém a implantação do governo eletrônico na América Latina, com exceção do Chile e do Brasil, nos demais países iniciou-se mais tardiamente.

Os principais problemas desses outros países são:

- Falta de uma política direcionada para o e-gov;

- Regulamentação em geral;

- Resistências governamentais;

- Confusão sobre as Agências Governamentais sobre quem tem que regulamentar esta área.

Por isso além de regulamentações, precisam resolver questões como inclusão digital, transparência, vontade política e assim deslancharem com os programas nacionais de e-gov.

Os problemas enfrentados pelo continente estão ligados à falta de investimentos em tecnologia, falta de disponibilidade de hardware, baixo índice de acesso à internet, carência de recursos humanos, ressalta-se ainda a baixa renda da população, que dificulta a inclusão digital.

Além de políticas nacionais é preciso haver intercâmbio de conhecimento e práticas. 
O Sistema de Compras Públicas do governo brasileiro já é utilizado pelo Peru e há negociações com Argentina, Equador e Chile para o desenvolvimento de projetos ligados à interoperabilidade no continente latino americano.

Integrar sistemas de informações aduanas, portos, aeroportos, processos envolvendo o fluxo de pessoas, mercadorias, certificação de documentos entre outros.

É necessário firmar acordos para a integração dos sistemas de informação e das iniciativas de governo eletrônico dos países da América Latina. Para efetivamente integrar o continente e viabilizar os entendimentos mútuos estabelecidos entre os diferentes países.

A seguir uma tabela do mesmo levantamento da ONU apresentado anteriormente, específico para a América do Sul.

\begin{tabular}{|l|l|l|l|l|}
\hline País & Índice 2008 & Índice 2005 & Posição 2008 & Posição 2005 \\
\hline Argentina & 0.5844 & 0.5971 & 39 & 34 \\
\hline Chile & 0.5819 & 0.6963 & 40 & 22 \\
\hline Brasil & 0.5679 & 0.5981 & 45 & 33 \\
\hline Uruguai & 0.5645 & 0.5387 & 48 & 49 \\
\hline Colômbia & 0.5317 & 0.5221 & 52 & 54 \\
\hline Peru & 0.5252 & 0.5089 & 55 & 56 \\
\hline Venezuela & 0.5095 & 0.5161 & 62 & 55 \\
\hline Bolívia & 0.4867 & 0.4017 & 72 & 85 \\
\hline Equador & 0.4840 & 0.3966 & 75 & 92 \\
\hline Paraguai & 0.4654 & 0.3620 & 88 & 107 \\
\hline Guiana & 0.4375 & 0.3985 & 97 & 89 \\
\hline Suriname & 0.3472 & 0.3449 & 123 & 110 \\
\hline Região & $\mathbf{0 . 5 0 7 2}$ & $\mathbf{0 . 4 9 0 1}$ & & \\
\hline Mundo & $\mathbf{0 . 4 5 1 4}$ & $\mathbf{0 . 4 2 6 7}$ & & \\
\hline
\end{tabular}

Quadro 11 - Posição Mundial de Desenvolvimento de Governo Eletrônico na América do Sul

Fonte - Relatório da ONU: "United Nations e-goverment survey 2008 - From egovernment to connected governance". Disponível em: <http://unpan1.un.org/ intradoc/groups/public/documents/UN/UNPAN 028607.pdf> Acesso em 03 abr. 2009.

A Argentina superou o Chile e o Brasil e passou a liderar a região segundo o relatório da ONU. O fator determinante foi um aumento na infra-estrutura com um 
importante incremento de assinantes de celulares e aumento do número de computadores. Mesmo começando mais tarde num programa nacional de desenvolvimento de governo eletrônico, a Argentina tem apresentado ultimamente uma política "agressiva" na área. Bolívia, Equador e Paraguai também aumentaram as suas posições no Relatório 2008, melhorando a prestação de serviços on-line nas fases de interação e transação.

A seguir uma comparação dos pontos principais das políticas de Governo Eletrônico da Argentina, Chile e Brasil:

Os principais pontos positivos:

Brasil e Chile - ambos iniciaram com estratégias para o desenvolvimento do e-gov com forte comprometimento do poder executivo.

No Brasil, em 2000 o Grupo de Trabalho em Tecnologias de Informação (GTTI), estabeleceu um conjunto de diretrizes e metas que deram origem ao Programa de Governo Eletrônico brasileiro. E logo foi incorporado como uma política pública de desenvolvimento.

No Chile, em 1998, baseado na agenda chilena de Governo Eletrônico foi constituída a Comissão Presidencial de Novas Tecnologias, em 2000 o Comitê de Ministros de Tecnologias da Informação para coordenar as políticas públicas relativas à informática e o PRYME - Projeto de Reforma e Modernização do Estado, funcionou como uma agenda de governo eletrônico.

A Argentina iniciou-se mais tarde no governo eletrônico e somente no governo atual é que teve uma Agenda Digital elaborada, visando apoio de diversos setores da sociedade.

Outros destaques:

No Brasil - programas de inclusão digital e interoperabilidade (e-ping);

No Chile - parcerias com o setor privado, aceleraram o processo do e-gov;

As principais diferenças entre os dois países, é que no Brasil a política de governo eletrônico encontra-se centralizada nas esferas de governo, destacando-se a implementação do Software Livre e forte política de inclusão digital. O Chile adota a descentralização de ações e terceirização de serviços ao setor privado, possibilitando o rápido avanço do programa de governo eletrônico com a transferência ao setor especializado em tecnologias de informação e comunicação.

A Argentina prioriza parcerias com universidades e empresas privadas de serviços e investimentos.

Pontos Críticos: 
- O principal a ser destacado é a tímida participação popular no governo. A falta de canais abertos para controle social, opiniões e sugestões dos cidadãos, enfim, exercícios de democracia;

- Integração dos diferentes bancos de dados do país, para formar uma rede única que agilize ainda mais os trâmites apresentados à sociedade;

- $\quad$ Falta de mão de obra qualificada, formação técnica dos funcionários da administração pública;

- Mudança das organizações públicas (resistências);

- Uso do software livre;

- Desenvolver outros canais de e-serviços (celulares, cartões, etc.).

Os dois países (Brasil e Chile) adotaram estratégias de longo prazo com políticas bem estruturadas e este fato conduz a uma constante retroalimentação, comparação de experiências, reavaliação de projetos, ampliação de objetivos e atualização de modelos, dentro de um planejamento de longo prazo, que exige aperfeiçoamentos dia a dia pela própria dinâmica da evolução do conhecimento tecnológico." (informação pessoal) ${ }^{6}$

\subsubsection{Destaques de Casos de Sucesso no Mundo}

"O governo eletrônico é entendido como uma das formas de expressão da sociedade da informação, bem como o campo de ação no processo de modernização do Estado. Estabelece o uso estratégico e intensivo das tecnologias da informação e comunicação, tanto nas relações do próprio setor público entre si, como entre os órgãos do Estado com os cidadãos, usuários e empresas do setor privado." In: UNIVERSIDADE DO SUL DE SANTA CATARINA. Governo Eletrônico: estratégias de elaboração, desenvolvimento e implementação de projetos. $2^{\underline{a}}$ edição. Palhoça: Unisulvirtual, 2008. p. 205.

"A inserção da temática de Governo Eletrônico não é casual nem espontânea. Possui importantes antecedentes e faz parte de uma tendência internacional. $O$ debate sobre Governo Eletrônico está vinculado às tendências globais e às discussões relativas ao papel do Estado." In: UNIVERSIDADE DO SUL DE SANTA CATARINA. Governo Eletrônico: estratégias de elaboração, desenvolvimento e implementação de projetos. $2^{\text {a }}$ edição. Palhoça: Unisulvirtual, 2008. p. 203.

A seguir, destacam-se casos relevantes de políticas de desenvolvimento de governo eletrônico.

\footnotetext{
${ }^{6}$ Texto fornecido por Ana Clara Gonçalves, via internet, em 03/04/2009.
} 
O governo de Singapura empenha-se em conhecer as necessidades dos usuários e tem desenvolvido um amplo sistema de consultas através de focus group, pesquisas de opinião, painel de consulta e comissões de assessoria. Outro item de destaque é a personalização do portal podendo ser configurado de acordo com as preferências pessoais, definindo os trâmites de preferência. O usuário pode escolher entre cinco opções: estudante, dono(a) de casa, trabalhador adulto, pessoa de negócios e cidadão maior adulto.

Existe um sistema personalizado de alerta chamado My-eCitizen, que envia e_mail ao usuário para lembrá-lo sobre: renovação de passaporte, pagamento de impostos, consulta médica mensal, devolução de livros à biblioteca, entre outros.

Possui um buscador integrado em todo o Estado, pensado sob a ótica do cidadão, de tal forma que possibilita a entrada em todo o Governo, colocando desta forma o usuário no centro dos projetos de Governo Eletrônico.

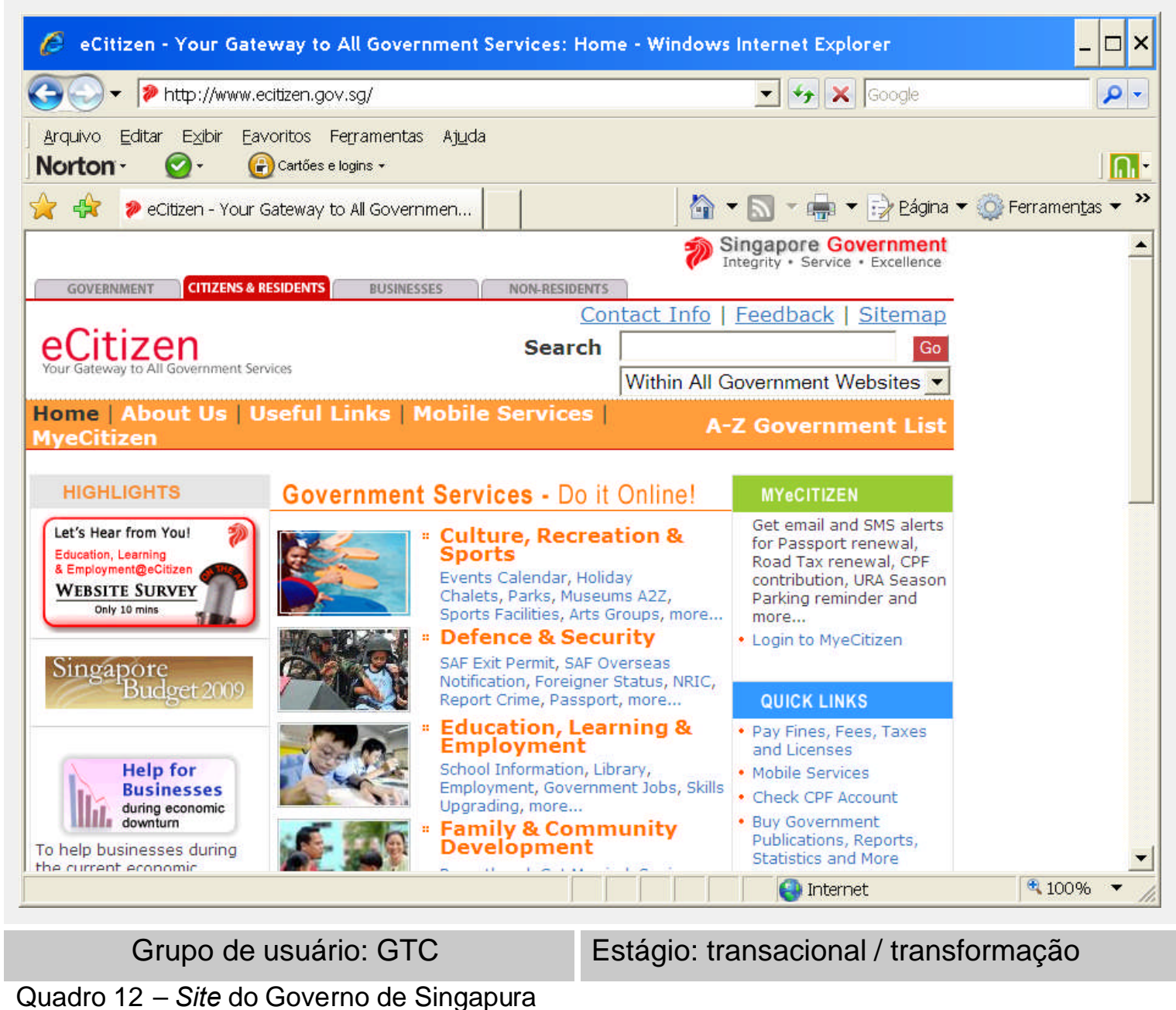


UNIVERSIDADE DO SUL DE SANTA CATARINA. Governo Eletrônico: estratégias de elaboração, desenvolvimento e implementação de projetos. $2^{\underline{a}}$ edição. Palhoça: Unisulvirtual, 2008. p. 226.

\section{Governo da Coréia}

\section{www.korea.net}

Estabelece planos de cinco e dez anos de prazo, com metas claras, ambiciosas e mensuráveis. Encontra-se no terceiro plano mestre, onde se destacam alguns fatores de sucesso, como o apoio do parlamento que elabora ajustes legislativos necessários às iniciativas, os partidos políticos formaram uma comissão especial para assuntos de Governo Eletrônico. Há colaboração entre as agências de governo e setor privado para o desenvolvimento de projetos de infra-estrutura e infoestrutura (sistemas de informação). Existe um Comitê de Governo Eletrônico organizado em grupos de trabalho juntamente com a sociedade civil, para elaborarem metas e planos estratégicos. Consideraram dois aspectos centrais nas propostas do comitê: a visão centrada no cidadão e a visão de integração inter governamental, além do forte comprometimento do Presidente, que segue de perto o tema.

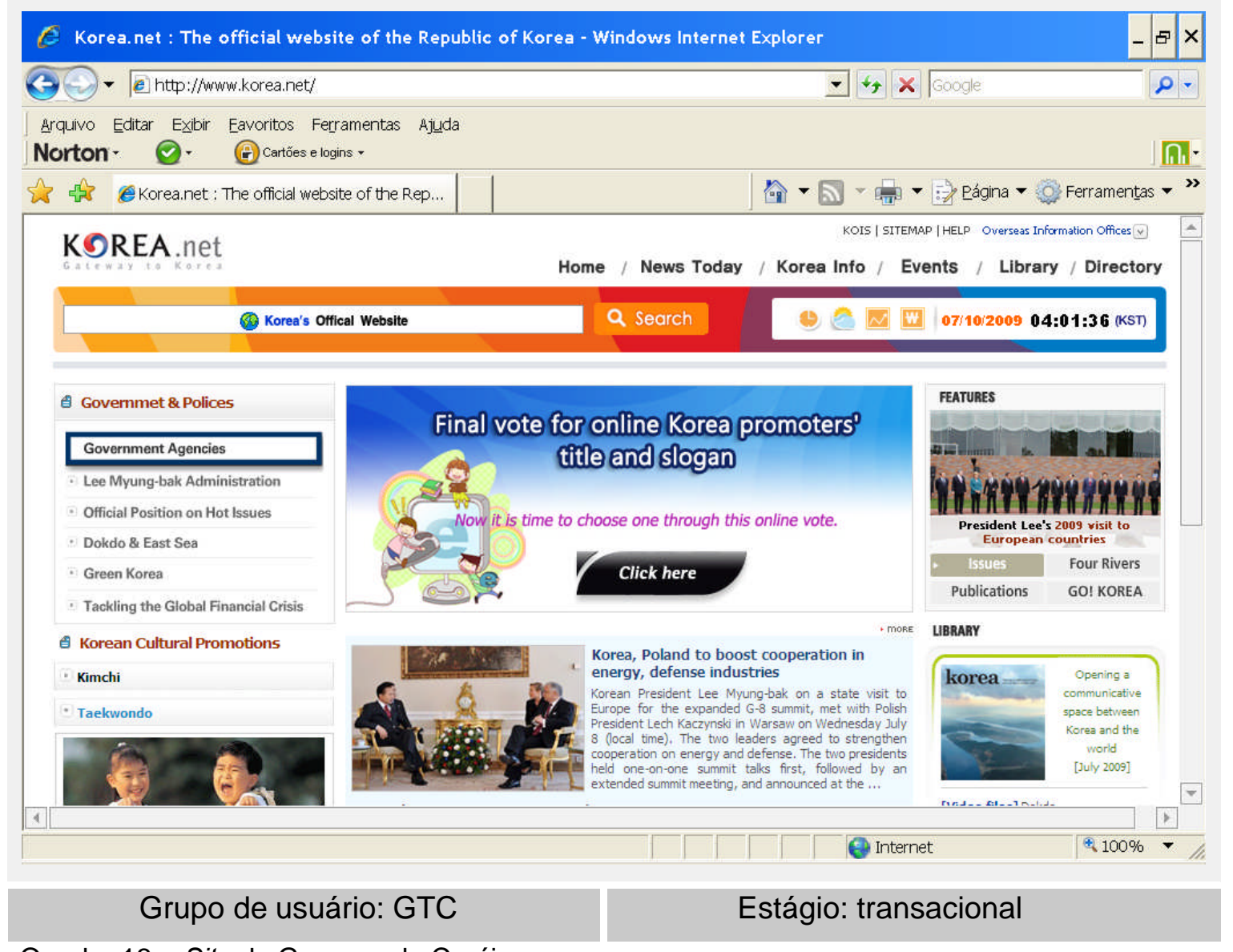

Quadro 13 - Site do Governo da Coréia 
UNIVERSIDADE DO SUL DE SANTA CATARINA. Governo Eletrônico: estratégias de elaboração, desenvolvimento e implementação de projetos. $2^{a}$ edição. Palhoça: Unisulvirtual, 2008. p. 229

\section{Governo do Canadá}

www.canada.gc.ca

Estabeleceu ainda em meados dos anos 90, a meta de ter todos os seus cidadãos conectados para o ano de 2002, seja pela via do acesso doméstico ou pela via de acesso nas escolas e telecentros.

O portal é dividido por tipo de usuários: visitantes, canadenses e empresas.

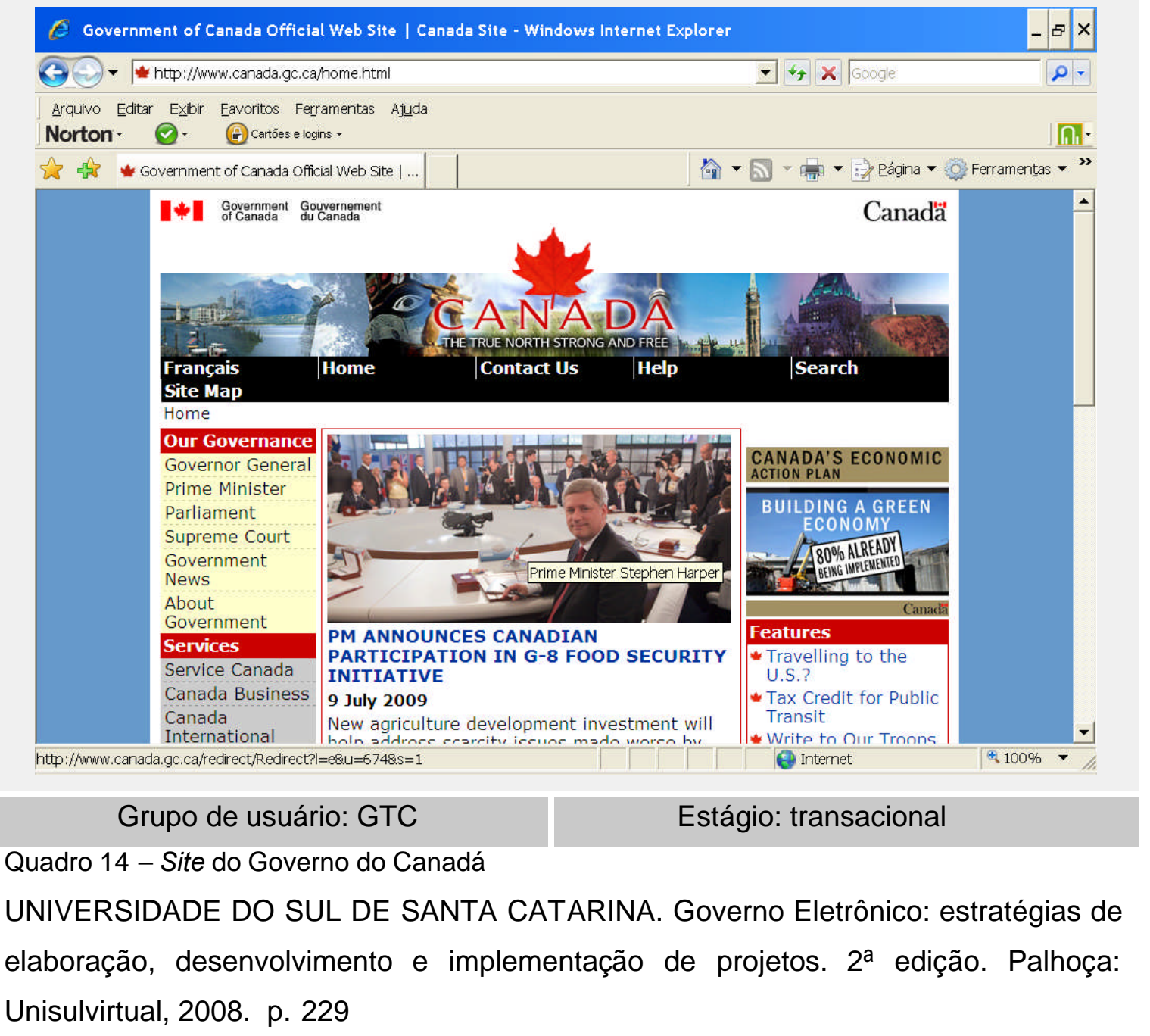




Governo do Estado de São www.saopaulo.sp.gov.br
Paulo

O conteúdo do portal é dividido em:

Notícias (com uma sala de imprensa com conteúdo exclusivo para jornalistas com e_mail e senha para acessar). Tem um ícone "Conversa com o Governador" programa semanal de entrevista com o governador que poderia ter acesso a um fórum de debates ou para os cidadãos registrarem opiniões etc., mas não há.

Conheça SP (Turismo, Cultura, História, Imigrantes e Patrimônio Artístico) todos com links para outros sites do assunto. Poderia ter mapas de localização e informações de como chegar, ou mesmo passeios virtuais em monumentos, museus e teatros, mas não tem.

Ações de Governo - destaque para: Acessa SP que é um programa de inclusão digital levando à população as novas TICs em especial a Internet e conta com mais de 3.500 computadores divididos em 406 postos do Acessa em 353 municípios (metade do Estado que tem no total 645 municípios)

Esse item tem informações também sobre educação, saúde, rodovias, habitação e outro destaque: o link para o e-Poupatempo.

O Poupatempo foi criado em 1997, onde ficam reunidos vários órgãos públicos num único local e prestam cerca de 400 tipos de serviços à população: RG, Carteira de Motorista, Certidões, etc. e agora conta com salas de atendimento:

"As salas de atendimento surgiram como uma inovação aos já existentes métodos de prestação de serviços públicos. Tratase de um ambiente computadorizado, amparado por uma equipe especializada no acesso aos serviços disponíveis na Internet.

Um dos principais objetivos da implantação destas salas é incentivar o cidadão a realizar os serviços eletrônicos por si próprios. Os atendentes atuam como facilitadores e auxiliam, quando necessário, a execução do serviço, seja na manipulação do equipamento ou na navegação da página do órgão responsável. Cabe aos atendentes acompanhar todo o processo e identificar as dificuldades e barreiras encontradas pelo cidadão e observar o comportamento dos usuários diante desta forma de atendimento.

Todos os dados coletados nas salas são analisados, proporcionando informações importantes para que os responsáveis pelos serviços conheçam o perfil dos cidadãos e em que pontos eles têm maiores dificuldades para a utilização dos serviços".

Governo do Estado de São Paulo: Salas de Atendimento. Disponível em: www.poupatempo.sp.gov.br/ e poupatempo/salas.htm Acesso em 23 mar. 2009 
Ainda no e-poupatempo existe o LablHC (Laboratório Interação Homem Computador) onde são feitas análises para implantação de páginas oficiais e seus serviços disponibilizados, seguindo normas e diretrizes para sítios e serviços da web. Este serviço é do tipo G2G (Governo para Governo).

No www.poupatempo.sp.gov.br/e_poupatempo/arquivos.htm pode-se acessar manuais e conjunto de recomendações de usabilidade para serviços públicos transacionais, construídas a partir da experiência adquirida no Laboratório.

Órgãos e Entidades - Links das Secretarias, Autarquias, Fundações e Prefeituras do Estado.

Além destes itens existem dois portais:

Investimentos.sp - é do tipo G2B (Government to Business), várias informações do estado por município, região e atividade econômica, guia do investidor, câmaras de comércio, agências reguladoras e destaque para um mapa do estado com banco de dados de informações que pode ser montado pelo usuário e impresso.

Cidadão.sp - Encontram-se todos os serviços para os cidadãos de forma organizada e simples. Links com serviços federais como Emissão de Certidões, Imposto de Renda e Previdência. Destaque para Boletim do Aluno que com seu no de R.A. tem o próprio Boletim para imprimir.

\section{Grupo de usuário: G2C, G2G e G2B Estágio: Transação}

Quadro 15 - Site do Governo do Estado de São Paulo

Para se atingir o estágio de Transformação nos governos, onde há integração completa dos serviços através das fronteiras administrativas, o sistema deve garantir o acesso a diversas fontes de informação de forma integrada (sem que o usuário perceba que está acessando base de dados diferentes) por exemplo: a composição de um mapa com informações de uma prefeitura conjugada com informações do Ministério da Fazenda.

O site também deve permitir o acesso do usuário ao gestor do sistema em situações que não consegue resolver, permitir o reconhecimento de usuários com privilégios de acesso a determinadas informações, entre outras, segundo os autores Nobre e Barruncho (2007 p.37). 


\section{O SISTEMA DE INFORMAÇÃO GEOGRÁFICA NO GOVERNO-ELETRÔNICO}

\subsection{INTRODUÇÃO}

O geoprocessamento potencializando o governo eletrônico surge no interior da administração pública da necessidade de se ter um mapeamento atualizado do município e todo o conjunto dos seus benefícios, todas as secretarias que vão trabalhar de forma integrada, utilizando uma série de instrumentos que permitem conhecer melhor o município e intervir de forma eficiente na distribuição de recursos e infra-estrutura.

O projeto de Sistema de Informação Geográfica consiste numa leitura precisa do município que envolve as etapas de:

- Atualização da base cartográfica;

- Recadastramento físico/territorial;

- Recadastramento fiscal;

- Recadastramento sócio-econômico (censo municipal).

Sempre que possível, utilizam-se os recursos já existentes no município, compatibilizando as necessidades do SIG às disponibilidades locais. Deve-se promover a democratização do acesso aos arquivos, informações e processo burocráticos. Agilizar e facilitar as relações dos usuários finais com órgãos e entidades da Administração Municipal, adotando vários canais de comunicação como internet, terminais de autoatendimento, telefonia celular, etc.

É necessário que desde a implantação do projeto, o enfoque seja a oferta de serviços da administração mais acessíveis para população, cidadãos ou empresas. Atualmente os softwares de geoprocessamento são constituídos por diversos objetos (pequenos programas que desenvolvem funções bastante específicas). Esses objetos, quando acoplados a programas de uso rotineiro da administração pública, fazem a integração dos dados colhidos no processo normal de trabalho (como atender um paciente no pronto-socorro ou a liberação de um alvará de habite-se) a uma base cartográfica, permitindo que o dado colhido seja imediatamente visualizado em um mapa.

Para a administração pública municipal, o geoprocessamento é uma função que deve estar disponível nos diversos sistemas utilizados para gerenciamento de cadastros, bancos de dados, nos aplicativos que executam funções gerenciais e sistemas voltados para $o$ atendimento público, sempre que a informação 
georreferenciada importe em maior agilidade e melhoria na qualidade da prestação de serviços.

Por exemplo, aplicativos para matrícula escolar, o sistema associa o endereço do aluno ao estabelecimento de ensino que está mais apto a atendê-lo, observando critérios de facilidade de acesso e disponibilidade do serviço. Aspectos demográficos ou de ocupação do solo de uma área urbana selecionada no mapa do município, permitem que se possa confrontar a capacidade de uma rede assistencial com a demanda da região, resultando na melhor adequação dos serviços à realidade local.

\subsubsection{Procedimentos Preliminares}

Antes de comentar os benefícios das geotecnologias inseridas no governo eletrônico é preciso ressaltar que se um órgão de governo, em qualquer instância, toma a decisão de oferecer um serviço público por meios digitais, deve em primeiro lugar revisar seus processos internos, porque haverá novas funções, habilidades, competências e principalmente procedimentos.

É comum haver casos de iniciativas que começam pela presença na Internet e posteriormente a readequação dos procedimentos internos. Não rever os sistemas da organização antes de disponibilizar serviços na web, não necessariamente leva ao fracasso, mas o caminho a ser percorrido ficará mais longo e possivelmente mais caro para adaptar o departamento à nova maneira de prestação de serviços.

Por isso, numa primeira etapa é muito importante que o Estado passe por um projeto organizacional dos processos internos.

Exemplos:

\section{Governo do Chile}

O Serviço de Impostos Internos www.sii.cl

(SII) do Chile, antes de disponibilizar os serviços na web, realizou uma profunda reengenharia dos processos internos. Entre eles, destacam-se a implementação de uma intranet, um sistema operacional para o controle do fornecimento, aplicações para fiscalização, sistemas de compras internas através da intranet, salários e remunerações, sistema de administração de pessoal e uma escola virtual. In: UNIVERSIDADE DO SUL DE SANTA CATARINA. Governo Eletrônico: estratégias de elaboração, desenvolvimento e implementação de projetos. $2^{a}$ edição. Palhoça: Unisulvirtual, 2008. p. 177)

Grupo de usuário: GTG

Estágio: antes da presença na internet

Quadro 16 - Site do Governo do Chile 
No caso do Sistema de Informações Geográficas, poucos municípios brasileiros conseguem manter um plano que atravesse várias gestões e que vá se aperfeiçoando. O que se vê na maioria das vezes é um projeto interessante que começa com atualização das bases de dados e bases cartográficas, implantação de determinado software, mas que depois fica abandonado ou subutilizado nas próximas gestões. No capítulo específico sobre Sistemas de Informações Geográficas são discutidos os aspectos que levam ao fracasso dos projetos.

Neste primeiro momento de implantação de Governo Eletrônico, fica clara a necessidade de uso e interação de um projeto SIG pelas diversas secretarias ou agências do governo, antes de se tornarem disponíveis ao cidadão pela Internet.

Abaixo, outro exemplo de reengenharia de processos antes do serviço na Internet:

\section{Governo do Brasil} www.receitanet.gov.br

A Secretaria da Receita Federal teve que modificar o antigo modelo tecnológico fisicamente centralizado e logicamente fragmentado para um paradigma que permitia consolidar o quadro completo da vida do contribuinte. Antes de implantar o ReceitaNet, foram analisados e revistos vários aspectos, destacando o processo de definição, geração e recepção das declarações, segurança da comunicação, garantia de integridade, custos de infra-estrutura, custos administrativos e recursos humanos especializados. UNIVERSIDADE DO SUL DE SANTA CATARINA. Governo Eletrônico: estratégias de elaboração, desenvolvimento e implementação de projetos. $2^{\underline{a}}$ edição. Palhoça: Unisulvirtual, 2008. p. 166)

\section{Grupo de usuário: GTG}

Estágio: antes da presença na internet

Quadro 17 - Site da Receita Federal - Brasil

Este modelo brasileiro foi pioneiro no mundo no uso da Internet para o envio de declarações e serviu de exemplo para sua utilização no Chile (1998), Portugal (1998) e México (2003), entre outros.

Os processos de integração de bases de dados de diferentes instituições públicas não são somente um problema técnico, mas também político, implicando mudanças culturais nas organizações, que se sentem proprietárias dos seus dados, além de outras dificuldades como a homogeneização da informação e a capacitação permanente de funcionários. Todos os processos de mudança organizacionais relacionadas com tecnologias de informação $(\mathrm{TI})$, requerem novas competências, habilidades e um aprendizado constante. 


\subsubsection{Conteúdo a Ser Oferecido}

Passada a etapa de reorganização dos procedimentos internos da administração pública, evolui-se para a etapa da "tela" da Internet propriamente dita. Devem-se distinguir três dimensões fundamentais de conteúdos oferecidos nos sites de governo eletrônico, são elas:

Informação, comunicação e serviços.

O nível ideal de governo eletrônico considera as três dimensões, contudo elas coincidem com a evolução das ofertas de conteúdos que passaram os sites governamentais.

\begin{tabular}{|l|l|l|}
\hline Dimensão & Foco & Conteúdo dos sites \\
\hline \multirow{2}{*}{ Informação } & Corporativa & $\begin{array}{l}\text { Missão, políticas, programas, } \\
\text { organograma. }\end{array}$ \\
\cline { 2 - 3 } & Interesse usuário & Leis, estudos, notícias, boletins. \\
\cline { 2 - 3 } & Transparência & Gestão, prestação de contas, auditorias. \\
\hline \multirow{2}{*}{ Interatividade } & Usuário - site & Mail ou formulário de contato, enquete. \\
\cline { 2 - 3 } & Usuário - instituição & $\begin{array}{l}\text { Consulta pública, Chat com autoridade, e- } \\
\text { mails de profissionais e autoridades. }\end{array}$ \\
\cline { 2 - 3 } & Usuário - usuário & Fórum, sala de bate-papo, diário, mural. \\
\hline \multirow{2}{*}{ Serviços } & Guia básico & $\begin{array}{l}\text { Perguntas freqüentes, buscador, manuais, } \\
\text { mapa do sítio. }\end{array}$ \\
\cline { 2 - 3 } & Orientação & $\begin{array}{l}\text { Guia de trâmites, formulários, cadastro de } \\
\text { consultores, fornecedores. }\end{array}$ \\
\cline { 2 - 3 } & Serviços on-line & $\begin{array}{l}\text { Consulta on -line, capacitação à distância, } \\
\text { trâmites on -line. }\end{array}$ \\
\cline { 2 - 3 } & &
\end{tabular}

Quadro 18 - Dimensão, Foco e Conteúdo dos Sites

Fonte: UNIVERSIDADE DO SUL DE SANTA CATARINA. Governo Eletrônico: estratégias de elaboração, desenvolvimento e implementação de projetos. $2^{\mathfrak{a}}$ edição. Palhoça: Unisulvirtual, 2008. p. 216

Além dessas três dimensões consideradas, deve-se levar em consideração quando um governo está disponível na web: a freqüência da atualização das informações, a pertinência regional ou local dos conteúdos, a usabilidade dos sites (se tem uma linguagem gráfica agradável e fácil) e a acessibilidade dos sites (se possuem ferramentas para deficientes, por exemplo). 


\subsubsection{Identificar o Que os Cidadãos Esperam}

Numa outra etapa de implantação de governo eletrônico deve-se conhecer o usuário dos serviços, ou seja, cidadãos e empresas com suas expectativas à prestação de serviços digitais.

Por isso, uma série de objetivos indiretos do governo eletrônico devem ser considerados:

- Serviços e trâmites on-line;

- Políticas de acesso;

- Gerência de relacionamento com o usuário.

Os serviços e trâmites on-line ofertados em plataformas eletrônicas são a expressão mais clara do governo eletrônico. Para os governos significa mais eficácia na gestão. Para os usuários a simplificação de trâmites. A presença de serviços nos sites governamentais fomenta o intercâmbio e reduzem-se os custos de operação. Porém, não se pode esquecer que o alcance da internet não atinge toda a população.

De acordo com a União Internacional de Telecomunicações - UIT, ou ITU em inglês, a porcentagem mundial de usuários com acesso a internet em 2005 era de $16 \%$, enquanto que na América Latina a média era de $14 \%$. No entanto, países como Canadá, Estados Unidos, Finlândia, Singapura e Suécia, mais de 60\% da população tinha acesso a internet em 2005, no Brasil, Colômbia, Venezuela e México, a média era de $12 \%$ a $16 \%$. INTERNACIONAL TELECOMMUNICATION UNION, Statistics, disponível em http://www.itu.int/ITU-D/ict/statistics/. Acesso em 30 de nov. 2007.

Por isso as políticas de acesso adotadas pelos governos são de extrema importância para garantir o acesso às tecnologias de informação e comunicação pelos cidadãos, promovendo todos os benefícios por elas geradas.

Nesse contexto, as principais iniciativas dos governos são as políticas de redes de telecomunicações, como a televisão digital, telefonia celular com tecnologia $3 G$, redes de acesso à banda larga e também soluções comunitárias como os telecentros e espaços públicos de acesso a internet.

Por último, e com relevante importância, destaca-se a gerência de relacionamento com os usuários.

Direcionar o Governo Eletrônico para os cidadãos implica em acolher ideias, propostas, críticas para retroalimentar a tomada de decisões. "Dar importância às opiniões dos cidadãos não somente fortalece a democracia como também torna mais efetiva a ação do governo". UNIVERSIDADE DO SUL DE SANTA CATARINA. Governo Eletrônico: estratégias de elaboração, desenvolvimento e implementação de projetos. $2^{a}$ edição. Palhoça: Unisulvirtual, 2008. p. 224 
Saber o que os cidadãos querem e precisam, coloca o Estado numa posição de credibilidade e confiança da população. Nesse quesito, o governo eletrônico tem vantagens porque permite vários canais de comunicação com a população.

Antes do surgimento da Internet ninguém poderia imaginar, por exemplo, acessar os arquivos com votação recebida por cada parlamentar, realizar trâmites on-line ou reclamar diretamente de sua casa ou escritório, da qualidade de um serviço, entre outros." (...) os mecanismos de feedback são os mais diversos, variam desde as tradicionais pesquisas de opinião e focus group, modalidades mais deliberativas como os fóruns eletrônicos, até as modalidades mais personalizadas, como responder e_mails que os cidadãos, eventualmente, enviam para uma instituição, seja para perguntar, dar uma idéia, fazer uma reclamação ou fiscalizar o serviço público.

No âmbito da Internet é importante, também, aprender a tornar relevantes as informações dos clientes/cidadãos obtidas nos diferentes canais de consulta. É igualmente importante aprender produzir estatísticas, assim como levantar hábitos de navegação para, dessa forma, ir ajustando a arquitetura da informação com as preferências das pessoas." In: UNIVERSIDADE DO SUL DE SANTA CATARINA. Governo Eletrônico: estratégias de elaboração, desenvolvimento e implementação de projetos. $2^{\underline{a}}$ edição. Palhoça: Unisulvirtual, 2008. p. 225

\subsubsection{Participação Cidadã no Governo Eletrônico}

Podem-se considerar três níveis de intensidade de participação cidadã no governo eletrônico:

\begin{tabular}{|l|l|}
\hline Nível & \multicolumn{1}{|c|}{ Atividade / Objetivo } \\
\hline Consultivo & $\begin{array}{l}\text { Consulta simples de opinião. Utilização da } \\
\text { internet para ouvir as pessoas. }\end{array}$ \\
\hline Resolutivo & $\begin{array}{l}\text { Democracia direta ou plebicitária. Utilização da } \\
\text { internet para sondar diversas matérias de interesse } \\
\text { público. Diferente das pesquisas de opinião, tem caráter } \\
\text { resolutivo (resolver-se algo após as consultas) }\end{array}$ \\
\hline Deliberativo & $\begin{array}{l}\text { Democracia eletrônica de compromisso cívico } \\
\text { on-line na deliberação política. É o modelo mais } \\
\text { complexo e mais democrático. (resolver após exame, } \\
\text { discussão) }\end{array}$ \\
\hline
\end{tabular}

Quadro 19 - Níveis de Participação Cidadã

Fonte: UNIVERSIDADE DO SUL DE SANTA CATARINA. Governo Eletrônico: estratégias de elaboração, desenvolvimento e implementação de projetos. 2ª edição. Palhoça: Unisulvirtual, 2008. p. 225 
Nota-se que a participação cidadã nos governos vem crescendo e evoluindo em todo o mundo, faz parte de um novo paradigma e será mais debatido no próximo capítulo. A presença dos sites governamentais favorece os canais de comunicação com a sociedade. Um exemplo que pode ser citado é a Agenda 2.012 da cidade de São Paulo, programa de metas com o objetivo de promover o desenvolvimento sustentável e a inclusão social com redução das desigualdades regionais e sociais. A Prefeitura disponibilizou no site www.prefeitura.sp.gov.br/agenda2012 para que a população entre em contato com o plano, acompanhe e debata com a administração do município o resultado das ações.

\subsection{A POSIÇÃO DO SIG NO GOVERNO ELETRÔNICO}

Sem dúvida o SIG não poderia deixar de fazer parte do governo-eletrônico, visto sua importância e similaridade com os recursos da web. Interagir com o cidadão disponibilizando serviços relacionados com a análise espacial do território.

Existem grandes esforços para os governos implantarem-se na web, mas para efetivamente terem um SIG funcionando ainda não há grandes projetos. É difícil encontrar SIGs ideais nos ambientes municipais, o que esperar então de SIG na internet?

É necessário que as autoridades responsáveis pela implantação do governoeletrônico compreendam o alcance do SIG como "fator potencializador do e-gov e como elemento essencial nos processos de transparência da gestão" Nobre e Barruncho (2007, p.44).

Nobre e Barruncho (2007, p.47) enquadram o SIG na mesma classificação anterior de estágios de governo-eletrônico, a seguir:

\begin{tabular}{|l|l|}
\hline Presença & $\begin{array}{c}\text { Apresentação de cartas, mapas, esquemas de forma } \\
\text { estática (geralmente uma imagem digital da carta em formato bmp, } \\
\text { tif, jpg, etc), ou ainda cartas contínuas de um determinado tema a } \\
\text { serem apresentadas utilizando ferramenta própria de navegação } \\
\text { (com funções simples como zoom in, zoom out, pan, etc). }\end{array}$ \\
\hline Interação & $\begin{array}{l}\text { O usuário pode fazer buscas dentro de um conjunto de } \\
\text { perguntas (dentro do município X, onde está a rua Y?) e obter } \\
\text { respostas do sistema on-line. Neste caso as cartas base são em } \\
\text { formato vetorial. } \\
\text { O sistema também deve permitir o acesso do usuário ao } \\
\text { gestor do sistema em situações que não consegue resolver. }\end{array}$ \\
\hline
\end{tabular}




\begin{tabular}{|c|c|}
\hline & $\begin{array}{l}\text { Deve permitir buscas alfagráficas. } \\
\text { Deve permitir o reconhecimento de usuários com } \\
\text { privilégios de acesso a determinadas informações. }\end{array}$ \\
\hline Transação & $\begin{array}{l}\text { O sistema de transação deve permitir ao usuário do } \\
\text { serviço pagar on-line por uma determinada carta ou tema e fazer } \\
\text { download da informação on-line. } \\
\text { Deve permitir a construção de uma carta on-line por } \\
\text { composição de diversos temas (inclusive com operações de } \\
\text { composição cartográficas completas) e subsequentes transações, } \\
\text { como compra on-line, etc. } \\
\text { Neste caso as cartas base são em formato vetorial. } \\
\text { O sistema também deve permitir o acesso do usuário ao } \\
\text { gestor do sistema em situações que não consegue resolver. } \\
\text { Deve permitir buscas alfagráficas. } \\
\text { Deve permitir o reconhecimento de usuários com } \\
\text { privilégios de acesso a determinadas informações. }\end{array}$ \\
\hline Trar & $\begin{array}{l}\text { O sistema deve garantir o acesso a diversas fontes de } \\
\text { informação de forma integrada (sem que o usuário perceba que } \\
\text { está acessando base de dados diferenciados). } \\
\text { Deve permitir ao usuário do serviço pagar on-line por } \\
\text { determinada carta ou tema e fazer downoad da informação on-line. } \\
\text { Deve permitir, tendo em conta o primeiro ponto, a } \\
\text { construção de uma carta on-line por composição de diversos temas } \\
\text { inclusive com operações cartográficas complexas e subseqüente } \\
\text { transação da mesma (compra on-line etc.) } \\
\text { O sistema deve permitir a composição de informação } \\
\text { espaço temporal e subseqüente transação da mesma. } \\
\text { Neste caso as cartas base são em formato vetorial. } \\
\text { O sistema também deve permitir o acesso do usuário ao } \\
\text { gestor do sistema em situações que não consegue resolver } \\
\text { Deve permitir buscas alfagráficas. } \\
\text { Deve permitir o reconhecimento de usuários com } \\
\text { privilégios de acesso a determinadas informações, independente do } \\
\text { ponto de acesso e da origem da autorização (aceitação cruzada de } \\
\text { usuários a sistemas diversos). }\end{array}$ \\
\hline
\end{tabular}

Quadro 20 - Classificação de Estágios de Desenvolvimento do SIG no Governo Eletrônico - Nobre e Barruncho (2007, p. 53)

\subsubsection{As Áreas de Atuação}

Com um completo banco de dados georreferenciado do município funcionando e disponibilizado na internet, diversos setores da sociedade são beneficiados: os cidadãos em primeiro lugar, com inúmeras facilidades na vida cotidiana; as empresas, onde a informação tem valor incalculável; para os governos que podem acessar o mesmo banco de dados e cruzando informações terem um diagnóstico preciso das áreas que necessitam maior atenção e por último para os 
próprios servidores públicos que tem seu trabalho mais preciso, tendo um acesso rápido de dados que antes estavam dispersos, muitas vezes em papel ou espalhado pelas secretarias e órgãos governamentais.

Portanto, o geoprocessamento no governo eletrônico atingiria todos os tipos de governo: G2C, G2B, G2G e G2E.

$\mathrm{Na}$ implementação de um SIG, devem-se planejar quais serviços serão disponibilizados no governo-eletrônico e trabalhar em conjunto desde o início do projeto para a compatibilização de todas as informações.

Nobre e Barruncho (2007, p.63) citam algumas áreas de atividade que são relevantes para o SIG:

- Zoneamento do território;

- Gestão do território;

- Turismo, lazer e cultura (localização de infra-estruturas turísticas, de lazer e culturais, localização de eventos num contexto espaço-temporal, etc);

- Cartografia e topografia (disponibilização de mapas, construção e elaboração de mapas)

- Cadastro, gestão e planejamento de:

Redes (abastecimento de água, telefonia, gás, eletricidade, metrô, etc.);

Equipamentos (urbanos, rurais, desportivo, cultural, etc.);

Atividades Econômicas;

Cadastro Predial;

Estrutura de segurança pública;

Transportes;

Serviços de saúde.

Ainda no relatório de Nobre e Barruncho (2007, p.70), conclui-se que nas diversas áreas de atuação que já existem disponibilizações de SIG na web em governo -eletrônico, a maioria ainda está voltada para: turismo, cultura, zoneamento de território e apresentação de algumas informações cartográficas. E em geral estão num dos dois primeiros níveis de desenvolvimento: presença e interação.

Por exemplo: em Portugal existe uma farta disponibilização de cartas de localização de turismo e cultura tais como: "restaurantes", "como chegar", "museus", "praias" etc, justificadas pelo potencial turístico que tem o país. Nobre e Barruncho (2007, p. 72).

Num segundo segmento, impulsionados pela necessidade de um governo transparente, na aplicação de recursos e diretrizes, alguns governos apresentam plantas de zoneamento locais, planta genérica de valores e alguns Planos Diretores 
são "colocados" na web, porém com qualidade insuficiente de elementos de base e apresentação pouco dinâmica.

Para se obter sucesso num projeto de governo eletrônico incluindo o projeto de um SIG, deve-se levar em consideração a abrangência proposta, número de entidades envolvidas, impacto social e econômico, tempo necessário de desenvolvimento, dimensionar o investimento e sua sustentabilidade.

Determinar os requisitos funcionais, técnicos e organizacionais de um Sistema de Informações Geográficas para um município, apresentado por um portal na internet.

O projeto de SIG na Internet presta serviços de apoio a cidadãos, incluindo residentes, turistas, investidores ou funcionários públicos, além de melhorar as condições da administração pública, pois o cruzamento de mapas da cidade com um banco de dados facilita diversos trabalhos, como: o cadastro de informações e sua atualização, diminuição do tempo de execução das tarefas, favorecimento na tomada de decisões, redução de custos, etc.

Outro objetivo da implantação do geoprocessamento na web é favorecer a incorporação de outros meios de governo eletrônico, como através de celulares ou smart card.

\subsubsection{Possibilidades de Aplicações}

Com as geotecnologias, diversos procedimentos inovadores podem ser adotados beneficiando o consumidor final: cidadãos e empresas em diversos níveis, como por exemplo:

\section{a) Nível de Informação}

O primeiro nível a ser fornecido num projeto de Sistema de Informação Geográfica é a disponibilização na internet de informações georreferenciadas do município, incluindo banco de dados do censo municipal e todos os mapas produzidos. Assim, população e turistas poderão ter acesso a diversos temas de seus interesses. Poderá funcionar também, como um localizador de equipamentos públicos e privados, já que o mapeamento do sistema viário fornece dados completos dos logradouros. Pode disponibilizar, além da localização dos equipamentos - desde escolas, hospitais, postos de saúde, farmácias, bibliotecas, parques, teatros, museus, restaurantes, etc, informações de como chegar, itinerário, quais ônibus e/ou linha de metrô que dão acesso. Dados sobre horário de funcionamento, telefone, capacidade de atendimento, compra de ingressos, passeio virtual pelo estabelecimento, consultas a acervos digitais, link de comunicação com suas administrações e mais uma infinidade de 
possibilidades que surgirão à medida que os sistemas de informação geográficas estiverem interligados.

Pode possibilitar, também, facilidades através do endereço georreferenciado para qualquer tipo de localização. Até pouco tempo atrás, um endereço eletrônico (e_mail) causava estranheza, hoje em dia é uma necessidade. Portanto não é difícil imaginar que em pouco tempo a identificação do endereço de um imóvel além do habitual, terá também seu endereço com coordenada geográfica. O endereço georreferenciado permitirá o acesso rápido de ambulâncias, polícias, correios e muitos outros veículos, que já utilizam GPS e chegarão ao imóvel em menor tempo, mesmo que a cidade ainda não disponha de um mapa digitalizado, como é hoje a realidade da maioria das cidades brasileiras, principalmente as médias e pequenas.

\section{b) Nível de Interatividade}

O nível de interatividade poderá conter um sistema de e-mail direto da administração pública para o cidadão, que poderá receber via computador ou telefone, avisos sobre vencimento de tributos, data de consultas médicas, data para matrículas, horário de chat para discussão de assuntos do município, etc.

O projeto de SIG no governo eletrônico, ainda poderá implantar um cartão único para identificação do cidadão que substituirá seus documentos como R.G., C.P.F., Título de Eleitor, Carteira de Habilitação, Carteira Profissional e Cartão SUS. Tudo agrupado num único documento, que poderá fazer parte de um processo de informatização em esfera nacional. Usará a mesma plataforma tecnológica que o Governo Federal usar no país inteiro para unificar seus bancos de dados e seguirá as mais modernas tecnologias de identificação, segurança da informação e assinatura digital para validar compras e outros procedimentos.

O cartão unico de identificação ainda poderá conter os dados relativos a:

- escolaridade: boletim, frequência escolar;

- saúde: prontuário, histórico de doenças, receituário, vacinação;

- Atividade Profissional: Tributos, Recolhimentos, Previdência;

- Localização da residência com coordenadas geográficas;

Todas as informações terão que estar submetidas a altos níveis de segurança e só poderão ser acessadas pelas instituições de direito. Por exemplo: dados da saúde só acessadas quando o cidadão precisar de atendimento médico e assim por diante. 
O governo poderá disponibilizar também informações sobre concursos públicos, compras públicas, banco de empregos, eventos, shows e notícias, através de canais como celular, tv digital e telecentros, além é claro, de seu portal na internet.

O cidadão responderá através destes meios digitais, tornando cada vez mais interativo seu exercício de cidadania. Poderá fazer denúncias, sugestões, votações, consultas, pedidos, através de qualquer mídia eletrônica e fazendo uso da componente de localização geográfica. Por exemplo: pontos de ônibus com uma tela com o mapa do itinerário dos ônibus, horários de parada, compra do bilhete de ônibus através do cartão único, etc.

Ainda no que tange a interatividade, o Projeto de SIG no e-gov deverá disponibilizar chat de conversa on line com funcionários da prefeitura (comunicação em tempo real). Poderá ter um acesso ao site da Câmara dos Vereadores relatando suas atividades, debates, próximas votações, e-mail dos vereadores, etc, sempre permitindo a interação com os cidadãos.

- Cartão Cidadão ou Cartão Único

O Cartão Único ou Cartão Cidadão não é uma possibilidade remota, pode ser baseada no programa do Cartão Cidadão de Portugal, implantado desde 2007 pelo governo e que seguiu as mesmas diretrizes de outros cartões únicos de documentos praticados por países europeus.

\section{Governo de Portugal}

http://www.cartaodecidadao.pt

Trata-se basicamente de um smart card $^{1}$ com grande capacidade de armazenamento de dados que substituirá grande quantidade de documentos hoje utilizados como: o Cartão do Contribuinte (CPF), o Cartão de Identidade (RG), o Cartão de Segurança Social (INSS), o Cartão do Serviço Nacional de Saúde (SUS), o Título de Eleitor, etc..

Esse novo cartão poderá permitir ao cidadão identificar-se presencialmente de forma segura, pois integrará vários elementos de segurança física e ainda poderá propiciar a autenticação eletrônica e a assinatura digital qualificada.

Quando este cartão puder ser implantado em todo o país, será um dos principais catalisadores da estratégia de modernização da Administração Pública empreendida pelo Governo Federal, atendendo aos objetivos de melhor acessibilidade aos serviços públicos, interoperabilidade de sistemas e colaboração entre organismos.

O documento de identificação poderá estar alinhado no contexto de uma política pública de desenvolvimento. O governo terá o compromisso de adaptar 
sistemas eletrônicos de identificação com elevados padrões de segurança, respeitando os direitos sobre proteção de dados pessoais.

O cartão único será multifuncional, além de um documento de cidadania, será também um grande instrumento de desenvolvimento tecnológico com imenso fator agregador, fundamental ao relacionamento rápido e eficaz entre os cidadãos e os diferentes serviços públicos e privados, independentemente do local onde se encontre e do meio de comunicação que utilize, constituindo-se num dinamizador da administração pública.

Principais aspectos da modernização:

- Segurança na identificação dos cidadãos;

- Unificação de vários documentos num único cartão;

- $\quad$ Autenticação e assinatura digital;

- Maior rapidez dos serviços públicos;

- Racionalização de recursos, meios e custos para o Estado, para os cidadãos e para as empresas;

- Simplificação de processos e de procedimentos da administração pública;

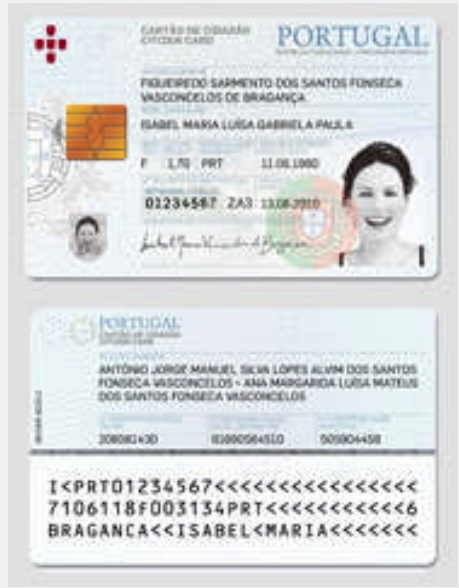

1. Smart card é um cartão que geralmente assemelha-se em forma e tamanho a um cartão de crédito convencional de plástico com tarja magnética. Além de ser usado em cartões bancários e de identificação pessoal, é encontrado também nos celulares GSM (o "chip" localizado normalmente atrás da bateria). A grande diferença é que ele possui capacidade de processamento pois embute um microprocessador e memória (que armazena vários tipos de informação na forma eletrônica), ambos com sofisticados mecanismos de segurança. É cada vez maior o número de cartões de crédito que utilizam a tecnologia. 
O cartão como instrumento de cidadania:

- $\quad$ O Cartão do Cidadão não vai expor dados sobre a situação fiscal, a saúde ou a segurança social do seu titular;

- A privacidade do cidadão será totalmente resguardada e o acesso aos dados pessoais só será permitido com o seu consentimento expresso;

- Toda a gestão dos dados será alicerçada no respeito aos direitos, liberdades e garantias dos cidadãos.

O Cartão do Cidadão permitirá um relacionamento multicanal através dos seguintes meios:

- $\quad$ Canal Internet / Portais de Governo;

- Canal telefônico

- Canal Presencial

O aumento do uso da internet é inquestionável, cada vez mais os softwares adotam bancos de dados mais simples, transparentes e seguros, permitindo que tecnologias novas possam ser utilizadas pelo cidadão comum, remotamente em qualquer lugar.

\section{Grupo de usuário: GTC Estágio: Transacional}

Quadro 21 - Site do Cartão Cidadão - Governo de Portugal

Governo de Portugal - Sobre o Cartão, disponível em http://www.cartaodecidadao.pt. Acesso em 03 nov. 2007.

\section{- Prontuário Médico:}

Outra possibilidade de uso poderá ser uma rede digital que interligue dados de secretarias municipais, postos de saúde e hospitais e poderá implantar prontuários médicos virtuais que integrados com Sistema de Informação Geográfica possibilitem aos gestores da saúde maior precisão na aplicação de políticas públicas.

Com um software, os funcionários do Sistema Único de Saúde (SUS) terão um prontuário virtual com um histórico de todos os serviços de saúde que o paciente se submeteu e uma relação de procedimentos agendados, além de dados como idade e sexo. O histórico de paciente poderá estar disponível em farmácias, postos de saúde e hospitais. As informações serão acessadas via internet, através da senha que os profissionais de saúde terão. O programa poderá ser implantado na rede pública de saúde, abrangendo hospitais, postos de saúde, hospitais universitários, entre outros. Cada paciente terá um tratamento mais particular, além de possibilitar ao governo 
direcionar ações de saúde para determinadas regiões em função de repetição de casos de alguma doença.

A seguir, um exemplo de implantação de inclusão digital no setor de saúde no Estado de Alagoas:

\section{Governo do Estado de Alagoas}

www.alagoas.gov.br

Setor de saúde inicia inclusão digital em AL

Programa de Alagoas inicialmente voltado a postos e hospitais deve expandir interligação de dados e abranger educação e segurança

Texto de Sarah Fernandes da Prima Pagina, Maceió 08/10/2007.

O sistema público de saúde de Alagoas deve começar a receber, no mês que vem, uma rede digital que permite interligar dados de secretarias municipais, postos de saúde e hospitais e implantar prontuários médicos virtuais - em que as informações sobre os pacientes possam ser acessadas a partir de computadores instalados nessas instituições. A ideia é que esse seja o primeiro passo de um projeto que pretende modernizar a comunicação digital dos órgãos públicos das áreas de saúde, educação e segurança pública e criar telecentros para a população usar computadores e internet.

As ações vão começar com a implantação de um projeto piloto no Segundo Distrito Sanitário de Maceió, uma região que abriga cinco bairros da capital alagoana (Trapiche da Barra, Pontal da Barra, Prado, Ponta Grossa e Levada) e cerca de 100 mil habitantes. A iniciativa é resultado de um convênio firmado entre o governo de Alagoas, a Microsoft, a Intel, o PNUD e o governo de Andaluzia (Espanha), que desenvolveu e implantou o software que interliga as informações, chamado Sistema de Saúde Digital Diraya. O programa foi doado a Alagoas pelo governo Espanhol.

Para a implantação do projeto piloto, a Microsof e a Intel vão liberar, esta semana, $R \$ 115.200$, divididos igualmente entre as duas empresas. O recurso deve ser usado para contratação de consultores nas áreas de saúde e tecnologia da informação. Eles farão um diagnóstico do sistema de saúde da região, implantarão o projeto piloto, e capacitarão cerca de 160 profissionais para usarem as ferramentas digitais.

O projeto piloto é resultado de um acordo de cooperação técnica entre os governos, as empresas de informática e o PNUD, assinado em 28 de setembro. A agência da ONU ficou responsável por selecionar os consultores; para isso, deve lançar um edital e contratá-los ainda neste mês. Ao todo, o projeto piloto no Segundo Distrito Sanitário deve durar quatro meses. Depois, a expectativa é que todo o Estado 
receba o sistema.

Com o software, os usuários do Sistema Único de Saúde (SUS) em Alagoas terão um prontuário virtual com um histórico de todos os serviços de saúde a que se submeteram e uma relação de procedimentos agendados, além de dados como idade e sexo. As informações poderão ser acessadas via internet, através da senha que os profissionais de saúde vão receber. O programa será implantado na rede pública de saúde, abrangendo hospitais, postos de saúde e hospitais universitários, entre outros.

A instalação do sistema faz parte de um programa desenvolvido no Estado, chamado Alagoas Inclusão Digital, que prevê modernizar os sistemas de comunicação digitais entre órgãos públicos. A iniciativa também deve reformular os portais de prefeituras e secretarias estaduais. "A idéia é fazer uma convergência de vários programas de inclusão digital”, afirma o coordenador do projeto de saúde digital, André Falcão.

Grupo de usuário: GTC

Estágio: Transacional

Quadro 22 - Site do Governo do Estado de Alagoas

Fonte: FERNANDES, Sarah. Saúde Digital In: Jornal eletrônico Prima Página, Maceió.

Disponível em: http://www.pnud.org.br/noticias/index.phpid01=2785. Acesso em $15 / 11 / 2007$.

- Histórico Escolar:

O mesmo que ocorre com o prontuário médico digital, poderá ocorrer com o boletim escolar, ou histórico. Com o Sistema de Informação Geográfica na secretaria da educação, cada criança que atingir a idade escolar poderá ser cadastrada num banco de dados, com endereço, notas e todos os dados da sua vida escolar e assim possibilitará ao poder público dimensionar a rede de ensino, distribuição de escolas de ensino fundamental, médio, técnico, etc. num determinado território. Favorecendo a política de educação.

\section{c) Serviços}

Quanto aos serviços oferecidos, poderá ser adotado no governo-eletrônico um link para cursos virtuais promovidos pela prefeitura e também em convênios ou parcerias com instituições de ensino. Exemplos:

- Cursos de capacitação técnica;

- Graduação;

- Especialização; 
- Cursos de interesse dos munícipes (Ex. Como utilizar as ferramentas de geoprocessamento);

- Arquivos para dowload: manuais, formulários, leis, etc.

Enfim, todos os serviços realizados no âmbito da administração pública poderão ser incorporados ao e-gov com o componente espacial, cada vez mais até a sua totalidade e o mais importante: estes serviços via web transformarão a forma existente hoje da administração publica municipal, sendo incorporadas ao longo do tempo, novos serviços, atividades e novas formas de relacionamento, onde o cidadão não será mais um expectador carente de cuidados, mas um agente transformador.

\subsubsection{Projeção dos Resultados Previstos com o SIG no Governo Eletrônico}

Impactos à curto prazo: Melhoria nas informações disponíveis e existentes nos sites e aumento da quantidade de serviços disponibilizados na internet, por causa da componente territorial com facilidade de visualização, impressão de mapas, etc.

Médio prazo: A consolidação do governo-eletrônico pela confiança nos serviços disponíveis, segurança das informações, aumento do alcance do e-gov, retorno das necessidades dos cidadãos e maior participação popular na tomada de decisões.

Longo prazo: Melhoria constante dos sistemas de comunicação: celulares que pagam contas, cartão único de documentos com inúmeras funções, internet livre e acessível para todos.

O Sistema de Informação Geográfica é usado hoje no mundo para diversas aplicações, mas usos futuros dessa tecnologia são muito interessantes, principalmente no quesito de transparência de ações de governo. Jack Dangermond, fundador da ESRI - Environmental Systems Research Institute, dá alguns exemplos que surgem nos Estados Unidos através de parcerias entre governo e a empresa fabricante de software, que dão uma amostra do que se pode construir:

\section{Entrevista sobre os usos futuros do www.govtech.com \\ SIG \\ O que é exatamente FedStat e como ele pode emparelhar com as iniciativas do governo Obama? \\ "O ex-prefeito de Baltimore, Martin O'Malley é atualmente governador de Maryland e em parceria com a ESRI desenvolve um programa estadual de controle de políticas e orçamento com sistema de informações geográficas. Em Baltimore, ele}


usou o SIG para construir o programa denominado CitiStat, um conjunto de ferramentas e procedimentos que Ihe permitia ver tudo o que estava acontecendo na cidade - a visão atual, onde localizavam-se as questões a serem resolvidas e como estavam resolvendo estas questões. Ele também criou sistemas de medição do desempenho dos trabalhos através de visualizações do uso das despesas públicas. Esse sistema aberto e transparente, fez com que a cidade pudesse escolher as melhores soluções e foi gerido pela administração de tal forma que as pessoas foram responsabilizadas por suas ações em um ambiente de políticas públicas. Basicamente foi uma evolução do lendário CompStat da cidade de Nova lorque - um sistema de atribuição de recursos da polícia com base em dados espaciais."

"Quando ele se tornou governador, contatou a ESRI e estamos envolvidos com a re-Maryland em uma maneira interessante. Nós começamos a tomar os seus mesmos conceitos de responsabilização do CitiStat e expandi-lo para StateStat e BayStat, para todo o Chesapeake Bay, para que ele pudesse entender racionalmente onde as questões estão localizadas - no caso de Chesapeake Bay, onde colocar dinheiro para limpeza da água, medir o efeito das suas despesas e fazer a mesma coisa em todas as estradas e os gastos governamentais. Quando o presidente Barack Obama foi eleito, ele olhou em Maryland e pensei: "Será que podemos ter essa mesma visão para o nível federal?" Então, começamos a brincar com o protótipo e visão de FedStat. Temos visto os primeiros indícios de como o protótipo visualiza as despesas públicas - primeiro onde há estímulo de financiamento, mais tarde todos os fundos governamentais e por fim visualizar onde o dinheiro está indo e orientar as pessoas que gastam este dinheiro para ter ações mais responsáveis e com melhor performance."

"É uma nova fronteira para o SIG. Trata-se de tomar o poder de visualização e análise espacial, e a abertura, para que governo, legisladores, administradores e praticamente todos possam ver e compreender abertamente o governo no futuro. É provavelmente uma das mais excitantes aplicações que eu já tive a oportunidade de apoio. Eu acho que vai mudar a forma como olhamos para nós mesmos e do nosso modo de executar a nossa democracia. É quase como um novo passo na evolução da própria democracia." 


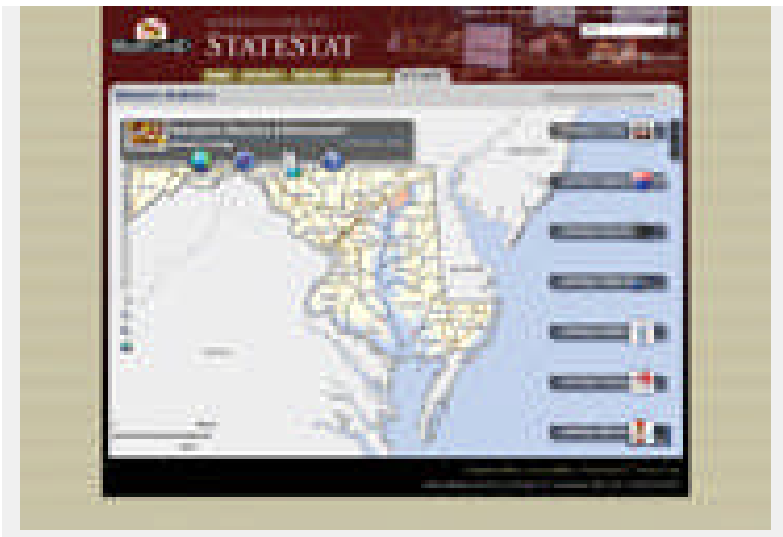

Mapeamento integrado de aplicações Web, como Maryland MD imap do site, fornecer o acesso do público à informação do desempenho governamental e oferecer uma nova plataforma de envolvimento dos cidadãos.

Como pode ser utilizada tecnologia SIG para monitorar o estímulo monetário e fazer o governo mais transparente?

"A primeira idéia de real benefício da computação aconteceu no mundo financeiro. O georreferenciamento das operações financeiras, que significam simplesmente colocar esses registros para o espaço, e isso significa pontos em um mapa - como esse projeto vai envolver tanto dinheiro, está atrasado ou precisa de mais orçamento. Mas é muito mais interessante do que apenas pontos em mapas. Trata-se de áreas, linhas e todas as interações entre essas coisas diferentes na economia. O SIG é fundamentalmente um sistema de informação, e é sobre o ordenamento territorial e geográfico das coisas. Eventos como gastos ou onde as pessoas vivem, projetam ou constroem e quanto dinheiro é gasto - são tão válidos como florestas, água e outras coisas que o SIG tem sido tradicionalmente usado."

(...) "O SIG historicamente tem mudado a forma como as pessoas pensam. Ele está mudando a forma de pensar, porque introduz as relações e os padrões que você só pode ver através de visualizações. Imagine quando todas as análises de energia estiverem cheias de capacidades SIG e à disposição de todos para que pudessemos ser mais atenciosos e pensativos sobre o que estamos fazendo com o meio ambiente. Poderemos olhar para o custo do desenvolvimento, o governo olhará as pessoas e poderá compreender e raciocinar sobre todas as implicações de uma ação do setor privado ou uma ação do governo, antes de fazê-lo. Podem criar modelos e discutir sobre isso, devem abrir os dados de forma regular e visível, os cidadãos podem se envolver na discussão e comentá-la. Isso vai mudar a nossa forma de operar como uma sociedade."

"A revolução causada pelo SIG está ocorrendo pouco a pouco. É 
fundamental para a forma de como as pessoas agem agora e será assim no futuro, como ele se torna mais penetrante, como se torna embutido em cada dispositivo. Ela vai ajudar a orientar-nos para onde ir."

Fim da Entrevista

acesso em 27/06/2009.

Quadro 23 - Entrevista sobre os usos futuros do SIG

Trecho da entrevista de Jack Dangermond, fundador da ESRI - Environmental Systems Research Institute, para o site para o site www.govtech.com em 01 maio de 2009, acesso em 27/06/2009.

\subsection{AS CONTRIBUIÇÕES DO GOVERNO BRASILEIRO}

O Governo Brasileiro vem contribuindo para a melhora da administração municipal com algumas medidas que serão comentadas a seguir, uma delas foram as diretrizes do Ministério das Cidades para a elaboração do Plano Diretor Participativo em 2006. E a outra, bem recente, é o Decreto Federal ํo 6.666 que trata da unificação de dados geoespaciais para o país inteiro.

\subsubsection{Plano Diretor Municipal do Ministério das Cidades}

O Plano Diretor Participativo, orientado pelo Ministério das Cidades, possibilitou que as cidades tivessem, a partir daí, instrumentos adequados de políticas públicas para a gestão urbanística e ambiental de seu território, que levam em consideração seu perfil de crescimento, as vocações sócio-econômicas e as características físico - territoriais locais.

Segundo o Estatuto da Cidade (Lei Federal 10.257 de 10 de julho de 2001):

O Plano Diretor é o instrumento básico da política de desenvolvimento e expansão das cidades. É o instrumento que define e induz o cumprimento das funções sociais da cidade e da propriedade do município. Tais funções devem assegurar - o atendimento das necessidades dos cidadãos quanto à qualidade de vida, à justiça social e ao desenvolvimento das atividades econômicas. In: ESTATUTO DA CIDADE. Lei 10.257, de 10 de julho de 2001. Disponível em: https://www.planalto.gov.br/ccivil 03/Leis/LEIS 2001/L10257.htm . Acesso em: 05/06/2009.

O Ministério das Cidades colocou parâmetros para os municípios entregarem o Plano Diretor Participativo até outubro de 2006, cerca de 1740 municípios no país inteiro se enquadraram nesta situação: 
- Municípios com mais de 20.000 habitantes;

- Integrantes de regiões metropolitanas ou aglomerações urbanas;

- Que possuam áreas de interesse turístico ou ainda;

- Situados em áreas de influência de empreendimentos ou atividades com significativo impacto ambiental na região ou no país.

O Ministério das Cidades orientou os municípios na elaboração do Plano Diretor Participativo disponibilizando um banco de experiências com o intuito de fornecer referências de processos e produtos feitos em vários pontos do país. Além da sistematização de experiências, o banco continha sugestões bibliográficas e legislações referentes aos planos diretores participativos e regularização fundiária sustentável. Porém, é bom frisar que não existe um modelo de Plano Diretor, são as demandas locais, as relações políticas e as características sócio-territoriais que variam de município para município que moldam o plano diretor.

A orientação do Ministério das Cidades é que fossem seguidos alguns passos:

1 ․ - Ler a Cidade - leitura para identificar e entender a situação do município: área urbana, área rural, seus problemas, seus conflitos e suas potencialidades. Constitui um processo de identificação e discussão das principais questões sob o ponto de vista de diversos segmentos sociais. Nessa etapa de leitura da cidade, o Ministério salienta a necessidade de mapear a cidade:

- Mapas temáticos sobre o território;

- Mapas de caracterização e distribuição da população e seus movimentos;

- Mapas de uso do solo;

- Mapas de infraestrutura urbana;

- Mapas de atividade econômica

Em cada etapa deveria haver a participação de diferentes segmentos da sociedade, a Prefeitura deveria disponibilizar informações promover conferências, fórum, debates etc.

2o - Formular e Pactuar Propostas - a partir da leitura, definir os temas prioritários para o futuro e para a reorganização da cidade. Um Plano Diretor deve ter a capacidade de intervir na cidade e não só diagnosticar. Para cada tema prioritário devem-se definir estratégias e os instrumentos mais adequados considerando as características e os objetivos da cidade que estarão contidos no Plano Diretor.

3ำ - Definir os Instrumentos - Como viabilizar as intenções expressas no Plano. Os objetivos e estratégias devem estar estreitamente articulados com instrumentos de planejamento e política urbana. 
4ํ- - Sistema de Gestão e Planejamento do Plano Diretor - a lei do Plano Diretor deve estabelecer a estrutura e o processo participativo de planejamento para implementar e monitorar o Plano, sua conclusão não encerra o processo de planejamento, ajustes podem e devem ser feitos. O próprio P.D. determinará os meios e a sistemática de revisão. A lei institui que o P. D. deverá ser revisto pelo menos a cada 10 anos.

O P. D. dever ser discutido e aprovado pela câmara dos vereadores e sancionado pelo Prefeito, o resultado formalizado como Lei Municipal é a expressão do pacto firmado entre a sociedade e os poderes executivo e legislativo.

A atividade de construir e elaborar o P. D. de cada cidade deve incentivar os municípios a avaliar e implantar todo o sistema de planejamento municipal. Esse planejamento implica em:

- Atualizar e compatibilizar cadastros;

- Integrar políticas setoriais, orçamentos anuais e plurianuais com o plano de governo;

- Capacitar equipes locais;

- Sistematizar e revisar a legislação.

A construção de um P.D. é também uma oportunidade para estabelecer um processo permanente de construir políticas, avaliar ações e corrigir rumos.

O P.D. deve garantir o acesso a terra urbanizada e regularizada, reconhece a todos os cidadãos o direito à moradia e aos serviços urbanos. Portanto, ele:

$1^{\circ}$ - Indica os objetivos a alcançar;

$2^{\circ}$ - Explicita as estratégias e instrumentos para atingir os objetivos;

3ํ- - Oferece todos os instrumentos necessários para que estes objetivos sejam cumpridos.

Diretrizes semelhantes às do Plano Diretor Participativo do Ministério das Cidades podem ser adotadas para o projeto de SIG municipal e também ter um direcionamento para sites governamentais.

A orientação do Ministério das Cidades para o Plano Diretor Participativo é que fossem seguidos alguns passos e pode haver o mesmo tipo de orientação para a implantação do SIG Municipal.

O Governo Federal pode oferecer aos municípios na elaboração do SIG no Governo Eletrônico, um banco de experiências, com o intuito de fornecer referências de processos e produtos feitos em vários pontos do país, além da sistematização de experiências, o banco pode conter sugestões bibliográficas e legislações referentes ao programa brasileiro de E-gov e de Cartografia. 


\subsubsection{Decreto Federal da Infraestrutura Nacional de Dados Espaciais - INDE}

O Decreto no 6.666 de 27/11/2008, institui, no âmbito do Poder Executivo federal, a Infra-Estrutura Nacional de Dados Espaciais - INDE, e dá outras providências.

Este Decreto cuja característica principal é de organizar o uso dos dados geoespaciais de origem Federal, Estadual, Distrital e Municipal, em proveito do desenvolvimento do País; promover a utilização e a produção dos dados geoespaciais nos padrões e normas homologados pela Comissão Nacional de Cartografia (Concar); e evitar a duplicidade de ações e o desperdício de recursos na obtenção de dados geoespaciais pelos órgãos da administração pública, por meio da divulgação dos metadados relativos a esses dados disponíveis nas entidades e nos órgãos públicos. In: BRASIL. Decreto oㅡ 6.666 de 27/11/2008. Disponível em: http://www.planalto.gov.br/ccivil 03/ Ato2007-2010/2008/Decreto/D6666.htm. Acesso em 05/06/2009.

Estabelece um marco legal para a criação da infraestrutura nacional de dados espaciais. Espera-se que a partir daí o Brasil inicie uma política forte, voltada a evolução na área geoespacial.

Da mesma forma que existem outras infraestruturas (comunicações, transportes, recursos energéticos) no âmbito federal, nada mais coerente que deva existir também a Infraestrutura Nacional de Dados Espaciais - INDE, com normas e diretrizes bem fundamentadas, a fim de permitir a integração de todas as bases de dados com as diversas esferas de governo.

Iniciativas internacionais podem ser usadas para assimilar informações e aprendizados importantes para a implantação da INDE. Além de outras iniciativas já em curso no Brasil, não só de implantação de IDEs, mas também do padrão de interoperabilidade (e-ping) do Governo Federal.

Uma iniciativa internacional que pode ser citada é a diretiva européia INSPIRE (Infrastructure for Spatial Information in the European Community) ou infraestrutura europeia de informação geográfica. Em vigor desde 2007, tem como objetivo:

\footnotetext{
" estabelecer um framework legal para a criação gradual e harmonizada de uma infra-estrutura europeia de informação geográfica. Esta iniciativa incidirá inicialmente nas necessidades de informação geográfica para as políticas ambientais, mas sendo uma iniciativa de natureza inter-sectorial, expandir-seá gradualmente para os outros sectores (e.g. agricultura, transportes, ...) à
} 
medida que outros serviços da Comissão passarem a participar na iniciativa. A criação da infra-estrutura europeia de informação geográfica permitirá a disponibilização junto dos utilizadores, de serviços integrados de informação de natureza espacial baseados na existência de uma rede distribuída de bases de dados, ligadas com base em standards e protocolos comuns assegurando a sua compatibilidade. Estes serviços deverão permitir a qualquer utilizador identificar e aceder a informação geográfica proveniente de diversas fontes, desde o nível local até ao nível global, de um modo interoperável e para uma grande variedade de utilizações.

Os utilizadores alvo da iniciativa INSPIRE incluem os responsáveis pela definição e implementação de políticas aos níveis Europeu, nacional e local bem como os cidadãos e as suas organizações. Potenciais serviços incluirão a visualização de diferentes níveis de informação, a sobreposição de informação proveniente de diferentes fontes, a análise espacial e temporal dessa informação, entre outros." INSPIRE - Infrastructure for Spatial Information in the European Community., Disponível em: http://inspire.jrc.ec.europa.eu/ Acesso em 24/04/2009

Além do INSPIRE para o continente europeu, há também iniciativas nacionais como o projeto IDE da Polônia, o SNIG - Sistema Nacional de Informação Geográfica e o SNIT - Sistema Nacional de Informação Territorial, ambos de Portugal.

O Decreto Federal Brasileiro no 6.666 de 27/11/2008 na íntegra, está inserido no anexo dessa dissertação.

\subsection{CONSIDERAÇÕES FINAIS DE GOVERNO ELETRÔNICO}

$\mathrm{Na}$ presente dissertação o governo-eletrônico, suas funções e evolução fornecem uma enorme contribuição no sentido de reforçar a justificativa do tema desta pesquisa, através de novos modelos de interação do governo municipal. Por meio dos recursos da Internet, o governo se faz mais presente, mais transparente, como já dito, e, principalmente mais responsável para cada vez mais melhorar seus serviços.

Os pontos fortes do geoprocessamento como fator potencializador do governo eletrônico são, primeiramente, o diagnóstico preciso da cidade com a clareza de dados para o administrador público tomar decisões baseadas em subsídeos técnicos. Depois, e não menos importante, é a democratização da informação através da internet. Cidadãos e empresas com ferramentas para suas atividades, sejam elas da vida cotidiana ou necessárias para uma empresa.

As conclusões sobre os projetos de governo eletrônico são:

- os projetos participativos têm mais chance de sucesso; 
- quando há participação popular existe maior legitimidade democrática;

- nunca se devem oferecer canais de comunicação e depois deixarem os usuários abandonados;

- os níveis de participação popular podem ser: consultivos, resolutivos e deliberativos;

- é fundamental projetar portais de governo eletrônico sob a perspectiva do usuário;

- é necessário conhecer os hábitos de navegação e as expectativas dos usuários.

Os casos de maior relevância em governo eletrônico apresentam pontos em comum, um deles é a visão de longo prazo sobre o desenvolvimento de políticas para as TICs, estabelecimento de metas claras e mensuráveis, além de forte comprometimento de liderança governamental (todos os planos de implantação de egov devem ser de longo prazo, não sujeitos a mudanças de governos e também sustentáveis a longo prazo)

Outro ponto comum aos casos de sucesso é a presença de uma liderança política dentro do governo que dê respaldo, poder e visibilidade às questões de governo eletrônico. Muitos comitês de coordenação de vários serviços tendem a ficar enfraquecidos.

É necessário também que se estabeleçam metas e planos estratégicos para o governo eletrônico, principalmente planos com ações graduais. Estabelecer metas audaciosas que podem começar com ações pequenas, porem progressivas. Os resultados vão aparecendo por etapas e já trazem benefícios desde os primeiros passos.

Os capítulos 3 e 4 destacaram a importância do Governo Eletrônico como uma revolução no processo de governar, talvez como nunca visto até hoje. Os Estados passam por uma profunda reorganização. As experiências apresentadas indicam a importância da padronização e simplificação dos processos administrativos: "Quando o projeto organizacional é claro e simples, a tecnologia serve para apoiar e fazer mais efetiva a gestão." In: UNIVERSIDADE DO SUL DE SANTA CATARINA. Governo Eletrônico: estratégias de elaboração, desenvolvimento e implementação de projetos. $2^{\mathrm{a}}$ edição. Palhoça: Unisulvirtual, 2008. p. 232.

A integração das diferentes fontes de dados e informações é um grande desafio para o governo eletrônico; além das dificuldades tecnológicas existem os interesses das instituições que muitas vezes não querem compartilhar dados. Por isso a necessidade da visão centrada no usuário e não nas administrações. A constante 
capacitação, treinamento e difusão da importância das TICs e modernas técnicas de gestão pública entre os funcionários públicos são fundamentais para que haja um real processo de transformação na forma de governar. É preciso que o setor público tenha a mesma competitividade em prestação de serviços que o setor privado e que possam oferecer serviços de tecnologia e alta qualidade.

Os portais de entrada do Governo, ou sites, são de grande valor para os cidadãos e precisam ter mecanismos a fim de garantir: a freqüência de atualização, fontes de informação e linha editorial. Informar não é promover. Quanto mais qualidade um site apresenta, maior a credibilidade do governo perante seus usuários - cidadãos. Além das questões gráficas, também são importantes a linha editorial e a arquitetura da informação. Deve-se levar em consideração aspectos como: acessibilidade e usabilidade. A primeira diz respeito a padrões que permitam que os sítios sejam visitados de qualquer navegador, sem a necessidade de equipamentos sofisticados e a segunda que seja fácil para o usuário navegar e conseguir a informação que deseja.

Enfim, procurou-se mostrar as inúmeras possibilidades de transformações públicas que podem ser oferecidas pela iniciativa de Governo Eletrônico e potencializadas pelo geoprocessamento. 


\section{NOVOS PARADIGMAS EM PLANEJAMENTO URBANO}

\subsection{INTRODUÇÃO}

Nesta pesquisa durante a leitura de vários textos sobre planejamento urbano, tem-se notado a presença constante de alguns termos atuais que representam uma evolução do pensar urbano. A importância deste capítulo está nos conceitos que foram necessários para se identificar além de SIGs em funcionamento, novas características nas gestões municipais. A participação popular, a valorização do cidadão como ator fundamental na cidade, a temática do meio ambiente e o planejamento estratégico, foram fundamentais para o desenvolvimento desta pesquisa e suas conclusões finais. Discute-se a seguir:

- O Desenvolvimento Sustentável;

- A Cidade Sustentável;

- A Gestão Participativa;

- $\quad$ O Plano Diretor Estratégico;

- $\quad$ O Marketing Urbano.

\subsection{O DESENVOLVIMENTO SUSTENTÁVEL}

Desenvolvimento Sustentável, segundo a Comissão Mundial sobre Meio Ambiente e Desenvolvimento (CMMAD) da Organização das Nações Unidas, é aquele que atende às necessidades presentes sem comprometer a possibilidade de que as gerações futuras satisfaçam as suas próprias necessidades.

A ideia deriva do conceito de ecodesenvolvimento, proposto nos anos 1970 por Maurice Strong e Ignacy Sachs, durante a Primeira Conferência das Nações Unidas sobre Meio Ambiente e Desenvolvimento (Estocolmo, 1972), a qual deu origem ao Programa das Nações Unidas para o Meio Ambiente - PNUMA.

Em 1987, a CMMAD, presidida pela Primeira-Ministra da Noruega, Gro Harlem Brundtland, adotou o conceito de Desenvolvimento Sustentável em seu relatório Our Common Future (Nosso futuro comum), também conhecido como Relatório Brundtland.

O conceito foi definitivamente incorporado como um princípio durante a Conferência das Nações Unidas sobre Meio Ambiente e Desenvolvimento, a Cúpula da Terra de 1992 - Eco-92, no Rio de Janeiro. O Desenvolvimento Sustentável busca o equilíbrio entre proteção ambiental e desenvolvimento econômico e serviu como base para a formulação da Agenda 21, com a qual mais de 170 países se 
comprometeram por ocasião da Conferência. Trata-se de um abrangente conjunto de metas para a criação de um mundo, enfim, equilibrado.

A Declaração de Política de 2002 da Cúpula Mundial sobre Desenvolvimento Sustentável, realizada em Joanesburgo, afirma que o Desenvolvimento Sustentável é construído sobre "três pilares interdependentes e mutuamente sustentadores" desenvolvimento econômico, desenvolvimento social e proteção ambiental. Esse paradigma reconhece a complexidade e o interrelacionamento de questões críticas como pobreza, desperdício, degradação ambiental, decadência urbana, crescimento populacional, igualdade de gêneros, saúde, conflito e violência aos direitos humanos.

O PII (Projeto de Implementação Internacional) apresenta quatro elementos principais do Desenvolvimento Sustentável - sociedade, ambiente, economia e cultura.

- Sociedade: uma compreensão das instituições sociais e seu papel na transformação e no desenvolvimento.

- Ambiente: a conscientização da fragilidade do ambiente físico e os efeitos sobre a atividade humana e as decisões.

- Economia: sensibilidade aos limites e ao potencial do crescimento econômico e seu impacto na sociedade e no ambiente, com o comprometimento de reavaliar os níveis de consumo pessoais e da sociedade.

- Cultura: é geralmente omitido como parte do desenvolvimento sustentável. Entretanto, valores, diversidade, conhecimento, línguas e visões de mundo associados à cultura formam um dos pilares do desenvolvimento sustentável e uma das bases da educação para o desenvolvimento sustentável.

\subsubsection{A Cidade Sustentável}

"A cidade sustentável é compacta, cidadã, solidária e planejada sobre os princípios do desenvolvimento sustentável, procurando sempre oferecer qualidade e diversidade de vida ao conjunto de seus habitantes", definiu a pesquisadora do Institut de Recherche pour le Développement (IRD/França), Márcia Mathieu (In: MATHIEU, Márcia. Desenvolvimento Sustentável. In: UnB Agência. Disponível em: http://www.unb.br/noticias. Acesso em 20/11/2007.)

Novamente tem-se percebido discursos parecidos sobre gestão de cidades e sustentabilidade, um desses pensamentos que se repetem em encontros, congressos na comunidade urbanística é a que o urbanismo tradicional favorece o zoneamento, tendo espaços fracionados e dispersos, a defesa da dispersão (por exemplo, Brasília) separada de acordo com as diferentes atividades (lazer, trabalho, política, consumo, 
etc), vem sendo substituída pela defesa de um ambiente compacto, que pode evitar o desperdício de energia, tempo e investimento.

Márcia Mathieu do IRD/França (Idem, Ibidem) descreve as seguintes características gerais das cidades dispersas:

- Congestionamento das vias de circulação periférica;

- Aumento do deslocamento pelas grandes distâncias entre a moradia e o trabalho;

- Poluição e queda da qualidade de vida;

- Inexistência de serviços públicos em algumas áreas e subutilização em outras;

- Fragilidade da solidariedade e da convivência urbana.

Não há mais como afastar o problema ambiental de nossas discussões, nunca estivemos tão informados sobre as consequências das mudanças ambientais em nossas vidas.

Cerca de $80 \%$ da população brasileira vive em centros urbanos, daí a importância de refletir sobre os problemas da cidade e seus conflitos ambientais.

A partir da Constituição Federal de 1988, os Municípios ganharam expressividade jurídica nunca antes alcançada. A Carta Magna instituiu o chamado federalismo cooperativo, inserindo todos os entes da federação como destinatários do poder-dever de atuar na tutela do meio ambiente.

A Agenda 21, por sua vez, prega a descentralização política e administrativa na gestão ambiental. Pelo princípio da subsidiariedade, originário do Tratado da União Européia, as decisões devem ser tomadas pelo nível político mais baixo, por aqueles que estão mais próximos da situação potencialmente lesiva. Trata-se do fortalecimento do poder local.

A comunidade mundial em seus últimos encontros para o debate da questão ambiental, tem se posicionado: somente o agir local poderá, eficazmente, influenciar na conservação do planeta.

Esse agir local possui diversas formas de ser concebido, englobando desde a educação ambiental até o complexo controle jurídico ambiental. Contudo, inconteste está o emergente Estado de Bem - Estar Ambiental, que define bem Capella apud Banunas (2003, p. 84):

"como a forma de Estado que se propõe aplicar o princípio da solidariedade econômica e social para alcançar um desenvolvimento sustentável, orientado 
a buscar a igualdade substancial entre os cidadãos, mediante o controle jurídico do uso racional do patrimônio natural."

O arcabouço legal e ambiental existente em nosso país possibilita, sem sombra de dúvida, uma eficaz proteção aos recursos naturais, necessitando apenas de sua maximização quando de sua aplicação pelo poder local.

\subsubsection{O Papel da Informação Geoespacial e o Desenvolvimento Sustentável}

A informação geoespacial pode dar suporte a diversas atividades que promovem ações direcionadas ao desenvolvimento sustentável. Disponibilizadas a cidadãos, empresas e governos, fornecem informações de apoio às decisões em tempo real, esta disponibilização da geoinformação favorece todas as áreas de atividades sócio econômicas, aumentando a transparência de vários atos administrativos.

Antigamente, a produção de cartas retratava o espaço de forma estática, devendo sua qualidade ser garantida à data a que a carta foi feita. $\mathrm{Na}$ contemporâneidade, a rapidez da informação precisa estar associada ao espaço e ao tempo real da ocorrência dos fenômenos ou atividades.

Um bom exemplo, são os indicadores estatísticos e metereológicos que espacializados e disponíveis globalmente podem nortear ações de política pública até entre nações. Mapa da distribuição da fome no mundo, da agricultura, etc.

A geoinformação pode proporcionar à sociedade e, de um modo especial, aos tomadores de decisão, os elementos essenciais para uma melhor gestão do espaço, preservando-o para as futuras gerações.

Assim como o Brasil instituiu o decreto para a criação da INDE Infraestrutura Nacional de Dados Espaciais, outros países vêm empenhados neste assunto também. Com a criação das IDEs - Infraestruturas de Dados Espaciais em países ou regiões, podem-se criar condições para compartilhamento de dados entre eles e consequentemente permitir diagnósticos e acompanhamento do meio ambiente, propiciando análises integradas e coerentes, criando inúmeras vantagens do intercâmbio de informações.

As informações geoespaciais propiciam identificar variações, comportamentos, processos e tendências, estabelecem comparações entre áreas, indicam necessidades e prioridades. Por isso propiciam a formulação, o monitoramento e a avaliação de políticas. 
Outro ponto a ser destacado é a importância da articulação entre os bancos de dados e sistemas desenvolvidos pelas instituições geradoras das geoinformações, para que possam auxiliar a análise de riscos ambientais, fenômenos e níveis de ameaça ao meio ambiente. A criação de uma rede integrada de geoinformações possibilita aos tomadores de decisão o gerenciamento de forma otimizada e rápida tanto na ocupação da terra como em situações de emergência.

\subsubsection{A Importância do Agir Local para Influenciar Globalmente}

O novo paradigma que se forma do Estado de Bem-Estar Ambiental, confirma que para haver o desenvolvimento sustentável é necessária a aplicação do princípio da solidariedade econômica e social, que implica na capacidade do homem em identificar o suficiente para a sua sadia qualidade de vida, redirecionando esforços não para o acúmulo de riquezas, mas para a busca da igualdade substancial entre os cidadãos.

Assistiu-se a Estocolmo em 72 e no Rio em 92. Os princípios desses eventos evoluíram junto com seus atores socioambientais, porém conclui-se que só agindo localmente, será alcançada a plenitude global. De todos os princípios relacionados pelas Nações Unidas, o agir ético dos movimentos sociais vem se destacando como o grande propulsor da aquisição do novo paradigma. A busca pela melhor qualidade de vida, ao combate às dominações, às desigualdades, às opressões em nossa sociedade e à defesa do meio ambiente, constituindo novos atores e novos sujeitos, capazes de prever e decidir a convivência equilibrada entre os seres humanos e a natureza em um novo tempo ecológico, caracterizador do Estado de Bem Estar Ambiental.

Assim, as cidades têm assistido, quase de forma simultânea, igualmente no Brasil, a questão ambiental pressionada pelos movimentos sociais e pelo oportunismo do Estado.

Avolumou-se a consciência ambiental, quando na pré-constituição de 1988, em diversos setores, desencadeando um capítulo exclusivo sobre o meio ambiente na Constituição. O Bloco Parlamentar Verde, tentou, em conjunto com atores multissetoriais dos movimentos sociais, alinhar a via do Estado ao Estado de BemEstar Ambiental. Com isso o Brasil conquistou uma Constituição das mais avançadas do planeta. Mas é na competência comum da União, dos Estados e dos Municípios que se assistiu ao maior passo da Carta Magna:

"No que diz respeito à esfera pública, o texto constitucional introduz como novidade a ação concorrente das três esferas da federação (União, Estados e Municípios) como co-responsáveis pela garantia da 
qualidade ambiental, prevalecendo a norma mais restritiva. Objetivamente, significa dar mais autonomia a estados e municípios para exercitar políticas ambientais.

De fato, a discussão sobre o papel do município na gestão ambiental urbana intensificou-se a partir de 1988. Tanto ambientalistas como governantes "descobriram"que o nível local é o lugar onde efetivamente existem maiores condições para contenção, prevenção e solução da maioria dos problemas socioambientais. O que passou a orientar essa nova visão político-administrativa foi a percepção de que o desenvolvimento urbano daqui para a frente deverá ocorrer, necessariamente, sob bases socioambientais sustentáveis. Ë que até meados da década de 80, a maioria dos ambientalistas brasileiros eram alheios ao problema do desenvolvimento: ecologia e economia eram percebidos como realidades antagônicas. Banunas (2003, p. 107):

Os princípios da Conferência das Nações Unidas em Estocolmo (1972) influenciaram diretamente a Constituição de 1988. Porém, só com a Eco 92 que se obteve o princípio número 4, a maior revelação que os tempos históricos ecológicos transmitiram, tendo se originado no liberalismo, com a comprovação negativa do binômio desenvolvimento econômico versus crescimento econômico a qualquer custo. Esse crescimento a qualquer custo legou um passivo ambiental mundial indeterminado, impossível de ser recuperado. Assim, é necessário que se esteja ciente de que o desenvolvimento só é possível se ele for sustentável.

Princípio no 4 da Eco 92: "Para se alcançar o desenvolvimento sustentável, a proteção do meio ambiente deve constituir parte integrante do processo de desenvolvimento e não pode ser considerada isoladamente em relação a ele." Banunas (2003, p. 92).

Nesse princípio baseia-se 0 art. 170 da Constituição, que estabelece a "ordem econômica, fundada na valorização do trabalho humano e na livre iniciativa," assegurando "a todos uma existência digna, conforme os ditames da justiça social" entre outros, o do inciso VI: a "defesa do meio ambiente".

Desta forma, o Poder Municipal Ambiental, ao desenvolver seu arcabouço legislativo ambiental, deve estar atento a esse princípio para que possa, não só em sua Lei Orgânica, mas no seu Plano Diretor e demais leis municipais, influenciar a administração marcando presença do princípio do desenvolvimento sustentável. Ele deve estar materializado na comunidade, caminhando paralelamente ao crescimento 
econômico, com o uso racional dos recursos naturais e, sobretudo, com a sadia qualidade de vida das presentes e futuras gerações. Só assim, agindo localmente, terse-á o efeito global preconizado pela Organização das Nações Unidas em seus encontros.

O Estado de Bem Estar Ambiental é o novo paradigma que surge. Cada vez mais o homem toma consciência que os conflitos econômicos, sociais e ambientais estão destruindo o planeta e é necessário que seja abandonado o ultrapassado conceito de acumulação de riquezas para uma nova concepção de vida fundamentada na solidariedade, sob pena de sua própria extinção.

O agir local para influenciar globalmente e vice versa, o pensar global implica no agir local e isso eleva a importância do poder local. E assim têm as organizações mundiais atuado: diversos são os encontros, congressos e eventos que concluem pela grande importância da articulação local, como o único meio eficaz de influenciar na conservação do planeta.

\subsection{GESTÕES DE CIDADES E METRÓPOLES}

O termo "gestão" há muito tempo estabelecido no ambiente profissional ligado à administração de empresas, vem desde o final do século $X X$, adquirindo popularidade em outros campos como o urbano e o ambien tal.

Para muitos a palavra gestão vem em substituição a palavra planejamento. Porém planejamento e gestão possuem referenciais temporais e tipos de atividades diferentes. Planejar remete ao futuro, está relacionado a um esforço prognóstico e deve utilizar-se da construção de cenários, simulando desdobramentos de um processo. Gestão remete ao presente, gerir significa administrar o hoje, utilizar recursos disponíveis tendo em vista as necessidades imediatas.

\subsubsection{As Regiões Metropolitanas}

O Brasil possui hoje 26 regiões metropolitanas institucionalizadas que somam no total 390 municípios, além das oficialmente instituídas, existem também as aglomerações urbanas, não institucionalizadas, polarizadas por capitais de estados, e as capitais que não configuram aglomerações, perfazendo um total de 37 espaços urbanos nacionalmente relevantes e compostos por 471 municípios. (MOURA et al. 2009 , p. 19). Essas regiões contam com alternativas administrativas que auxiliam a resolução de problemas de alcance regional, como os comitês de bacia, pactos territoriais e mais recentemente os consórcios municipais.

Os consórcios não precisam estar necessariamente atrelados às RM, mas podem oferecer soluções interessantes mesmo que num âmbito mais restrito. O Brasil 
está há pouco tempo acostumando-se com a prática de consórcios, que já funcionava no mundo todo. Aqui, a lei que regulamenta os consórcios municipais é de 2005.

A gestão metropolitana enfrenta ainda outros entraves, como o exacerbado poder que os municípios detêm e que depois da constituição de 88 ficou ainda maior, sendo elevados à categoria de entes federativos como os estados da União, o que acaba dificultando a gestão de problemas comuns das RMs, pois cada município quer garantir seu status de poder.

No Brasil, os conselhos das RMs são compostos pelos prefeitos e quando muda-se a gestão mudam-se também os conselhos, impedindo de ter uma continuidade de ações. Em outros países há exemplos de conselhos eleitos pela população e que desenvolvem programas estratégicos.

A descentralização do poder municipal é uma alternativa para a gestão de cidades, que criaram subprefeituras com recursos próprios e os chamados cidadebairro, que é um outro modelo administrativo com a instituição de um gerente-síndico para cada bairro, propiciando mais agilidade e melhoria da qualidade de vida por se aproximar mais dos cidadãos.

A gestão de cidades e metrópoles requer o envolvimento de múltiplos atores e é necessário seu envolvimento para a interação e cooperação para: formular objetivos comuns, sociabilização do conhecimento e troca de experiências. As tecnologias de informação e comunicação - TIC, favorecem a criação de redes fundamentais para este processo de interação.

\subsubsection{Práticas Globalizadas}

A cidade global adquire características de muitos lugares, de culturas diferentes e de condições econômicas também diferenciadas. A diversidade, as múltiplas facetas da cidade grande, a peculiaridade de cada bairro, dos imigrantes que há muito trouxeram seus costumes, perfazem um paralelo que vai do hostil da grandiosidade ao aconchego dos lugares conhecidos.

As diferentes características que estão presentes em cada canto, a velocidade de empreendimentos de todo o tipo, o fluxo dos capitais que determinam o "aquil" e o "ali" dos investimentos, são ao mesmo tempo centro de poder político, lugar de decisões econômicas, viveiro de idéias científicas, artísticas e filosóficas que propiciam infinitas possibilidades e um número tão superlativo de conflitos.

É incontestável que transformamos intensa e imperceptivelmente os espaços urbanos com as práticas cotidianas; porém, a intensificação do processo de globalização dos capitais impulsiona à transformação das cidades com uma rapidez que ultrapassa, de longe, os efeitos das práticas diárias. 
$\mathrm{Na}$ grande cidade ou metrópole do mundo globalizado, cruzam-se relações, processos e estruturas de todos os tipos e em diferentes direções.

Entende-se que é necessário discutir a cidade, estudar seus problemas, pensar soluções, porém não é o objetivo da presente pesquisa. Aprofundar conceitos e teorias a tornaria extremamente extensa. Portanto, optou-se por apenas identificar e comentar sucintamente os temas mais recentes que urbanistas de hoje estão discutindo.

A cidade global, metrópole ou ainda megalópole são regidas por fluxos de capitais que se sobrepõem à técnica de planejamento urbano. Um exemplo que ilustra bem é quando técnicos identificam que é necessária uma grande intervenção no sistema viário. A determinada obra fica sujeita a interesses políticos e financeiros que definem quando e como vão ocorrer.

Para isso, atuam em diversos sentidos, produzem novo espaço urbano, moldam-no às novas condições de fluidez do capital e, com isso, garantem, no mínimo e enquanto dura o processo de renovação urbana, a produção de renda imobiliária local. Nesse contexto entroncam-se planos estratégicos e planejamento urbano.

$E$, em um cenário marcado pela flexibilidade e negociação contínua, os administradores públicos das cidades optaram por um planejamento urbano comprometido por atuações urbanísticas em curto prazo e por estreitar a colaboração com os agentes privados de investimentos.

Recentemente por ocasião de o Brasil ter sido escolhido para sediar a Copa do Mundo de 2.014, as cidades que serão sedes dos jogos passarão por grandes intervenções. A expectativa é de que se melhorem as condições de transporte, infraestruturas, serviços, etc., que mais uma vez serão direcionadas pelo fluxo dos interesses.

\subsubsection{O Planejamento Estratégico}

Entre o discurso e a prática do planejamento urbano está a gestão pública dos planos urbanísticos, o que supõe constante negociação com os diferentes agentes econômicos e sociais para solucionar o conflito de interesses, em especial econômicos. Das negociações resultam, frequentemente, enormes distorções dos planos e de suas respectivas normativas.

O planejamento e a gestão estratégica têm sido as respostas que se mostraram mais adequadas ao novo perfil de gestão pública que a sociedade demanda.

As formas de gestão e de planejamento das cidades tiveram de se adaptar às exigências da reestruturação e da competitividade urbana. Assim, para levar adiante 
intensas e extensas operações urbanísticas, os administradores estabelecem amplas coalizões de agentes sociais, políticos e econômicos para convergir em interesses comuns: os planos estratégicos têm sido instrumentos idôneos, permitiram que o setor público estimulasse a iniciativa privada, bem como que os setores privados se convertessem em beneficiários diretos dos processos de reestruturação. planejamento estratégico posto em prática pelas administrações públicas na década de 1990, apresenta-se como uma alternativa para problemas de gestão pública inerente aos rápidos processos de transformação urbana, derivados, por sua vez, da intensificação da globalização do capital.

De certa forma, com o planejamento estratégico, a administração pública local pretende dissolver o totalitarismo do planejamento urbano que, ao excluir de forma habitual as opiniões de cidadãos e de agentes sociais e econômicos, e pode propor transformações dos espaços urbanos em nome do bem comum.

O planejamento estratégico enfatiza a participação social e econômica como meio para conseguir a interação dos agentes urbanos, a retroalimentação e a correção dos processos de transformação urbana. Em teoria, os planos estratégicos superam as limitações da perspectiva unidirecional dos planos urbanísticos. Porém, na prática, convertem-se em instrumentos que permitem agilizar a gestão pública dos interesses econômicos privados e pôr em prática com mais facilidade o planejamento urbanístico que atualmente, com mais ênfase, tende a concretizar-se em propostas de adaptação do espaço urbano às exigências de circulação e de materialização do capital.

Com o início do século XXI, as cidades ressurgiram como local estratégico para uma ampla gama de projetos e dinâmicas. Surgiu um novo papel econômico das cidades, através da globalização, uma nova geografia entre as cidades que contribui com uma infraestrutura de uma economia global, novos espaços culturais e novos tipos de políticas. Conferência URBAN - AGE, Rumo a Era Urbana (2008, p. 03), disponível em htttp.://www.urban-age.net/, acesso em 05/06/2009.

$\mathrm{Na}$ geografia intercidades existem fluxos densos e de grande visibilidade como o de profissionais, turistas, artistas, migrantes e outros fluxos mais discretos e quase invisíveis, como as redes de negócios financeiros, altamente especializados que conectam algumas cidades. Todos são circuitos multidirecionais que se espalham pelo mundo todo. O número de cidades que são atraídas para essas geografias intercidades está crescendo bem rápido. A globalização criou especificidades econômicas que permite perceber o papel diverso e particular das cidades no mundo.

Circuitos globais econômicos não são novos, o que mudou foi a proliferação de complexas estruturas organizacional e financeiras, desde a década de 1980, e daí 
surge a necessidade de prestar serviços e administrar a cidade que agora é estratégica.

\subsubsection{As novas políticas urbanas}

No marco crescente de competitividade internacional entre cidades, a política urbana foi se caracterizando por progressiva orientação rumo a captação de fluxos de capital, seja de consumidores - tratando-se dos próprios cidadãos ou turistas - seja de investidores.

As novas políticas urbanas estão acompanhadas da política posta em funcionamento pelos mecanismos de marketing e por elaborados discursos que permitam manter a harmonia social e a "ideologia do crescimento", afim de atenuar os possíveis conflitos sociais derivados das crises socioeconômicas resultantes da transformação espacial.

Esses mecanismos e discursos foram sendo construídos sobre a idéia de que as transformações urbanas produzem crescimento econômico e, portanto, postos de trabalho, e com base em um processo de produção intensivo (produção industrializada) de "identidade urbana" facilmente consumível e "assimilável" por objetos e slogans "identitários". "Amo São Paulo", slogan do $450^{\circ}$ centenário, ou "Barcelona més que mai", lançado para os jogos olímpicos e posteriormente, "posate guapa", são apenas pequenas mostras de práticas habituais de produção de "identidade cidadã" da maioria dos poderes públicos locais (municipais, metropolitanos, regionais).

A cidade parece menos o lugar de viver e de conviver do que do frenético centro de atividade e movimento. Neste mundo globalizado que com freqüência acostumou a se caracterizar pela circulação acelerada de fluxos de todos os tipos, as políticas urbanas parecem inspiradas por uma necessidade inevitável de capacitar os espaços para atrair mais fluxos, sejam investimentos, turismo ou, em geral, qualquer atividade suscetível de gerar movimento econômico.

A cidade, preparada para ser consumida, é apresentada como mercadoria e, para poder vendê-la, os governantes têm adotado formas de atuação empresarial.

O "marketing urbano" surge como uma expressão atual. Porém o marketing só explica uma parte da transação comercial, apenas expressa a estratégia do vendedor. Seu objetivo costuma ser estabelecido na "satisfação das necessidades e desejos dos consumidores de forma rentável" . A cidade agora se converteu simultaneamente em mercadoria (produto a vender), empresa (pelo seu modo de gestão) e pátria (pela criação do sentimento de posse e patriotismo da cidade). 
Estamos vivendo o momento do capital globalizado e instantâneo que visa o investimento em áreas que possam se transformar em mercadorias, empresas e pátrias. Os centros históricos fazem parte do movimento da cidade e quando recuperados atraem outros investimentos.

A participação popular está presente cada vez mais em diversos cenários, porém não ainda em situação ideal. É necessário para que se crie um sentimento de comunidade ou patriotismo de cidade e combater um ciclo vicioso que Peter Hall (1981) apud Oliveira et al, (2006), chamou de collective deprivation, quer dizer, a sensação de decadência e de falta de expectativas futuras, que conduz a uma sensação coletiva de alienação e apatia, percepção dos cidadãos que se transmite aos estrangeiros que tampouco investirão ali. Portanto a confiança no futuro teria a capacidade de provocar o contrário, como ocorreu em Barcelona de 1992, por exemplo.

\subsection{A GESTÃO PARTICIPATIVA}

A produção de conflito que existe na cidade conduz a uma discussão cotidiana das necessidades dos cidadãos. Todos têm que lidar com a cidade, seja no caminho para o trabalho, seja para um ou outro atendimento público que se precisa. Esse dia-a-dia de vivenciar a cidade, passando de problemas à tentativa de achar soluções, faz com que os indivíduos tenham consciência das questões sociais. Se uma pessoa tem dificuldade de matricular seu filho na escola, ela com certeza saberá identificar que existe o problema e se direcionada corretamente para a participação popular, será importante na discussão de soluções para a cidade. Esta produção de idéias é necessária para ações factíveis de participação popular.

\footnotetext{
"Assiste-se hoje ao paradoxo aparente da afirmação inconteste da democracia e da desilusão com ela.(...)

Abstecionismo, apatia, desinteresse, corrupção, crescimento dos interesses corporativos e particularistas são algumas das mazelas que costumam ser apontadas ao se questionarem as instituições políticas do presente" Félix R. Sanchez. (2003, p. 141-174)
}

Apesar da citação acima, percebe-se uma discussão crescente sobre a participação cidadã. No Brasil, a discussão ganha força com o processo de elaboração da Constituição de 1988. E depois de mais de 20 anos de tentativas, pode-se concluir que o sucesso de uma participação popular está diretamente relacionado com o desempenho e a orientação política dos governos locais. Estes devem ser atores 
principais, incentivando, organizando e fazendo valer a participação popular. E a população, por sua vez, mobiliza-se mais quando percebe que o resultado de sua participação pode influenciar diretamente no seu dia-a-dia. Portanto, a identificação e a divulgação dos efeitos de políticas governamentais na vida das pessoas, pode ser crucial para o sucesso da participação.

\subsubsection{Desenvolvimento Local}

O desenvolvimento local está associado ao termo de desenvolvimento econômico e ao crescimento, podendo corresponder à visão da ONU (IDH - Índice de Desenvolvimento Humano) e estar associado com bem-estar e qualidade de vida.

O índice de Desenvolvimento Humano é obtido pela média aritmética simples de três subíndices, referentes a: longevidade (expectativa de vida ao nascer), educação (índice de analfabetismo e taxa de matrícula em todos os níveis de ensino) e renda (PIB per capta, paridade do poder de compra), o resultado varia de 0 a 1 e quanto mais perto de 1 , melhor o desenvolvimento humano. O IDH pode ser calculado para países, regiões ou cidades. PNUD - Programa das Nações Unidas para o Desenvolvimento, disponível em http.://www.pnud.org.br, acesso em 10/06/2009.

Já o conceito de qualidade de vida é mais complexo, mais subjetivo, porque pode estar associado a questões culturais e outras variáveis não mensuráveis, mas para esta pesquisa considera-se a qualidade de vida como um conjunto de bem-estar individual, equilíbrio ambiental e desenvolvimento econômico, cujo conjunto pode ser entendido como um direito de cidadania:

"O termo qualidade de vida pode ser definido como: a soma das condições econômicas, ambientais, científicoculturais e políticas coletivamente construídas e postas à disposição dos indivíduos para que estes possam realizar suas potencialidades: inclui a acessibilidade à produção $\mathrm{e}$ ao consumo, aos meios para produzir cultura, ciência e arte, bem como pressupõe a existência de mecanismos de comunicação, de informação, de participação e de influência nos destinos coletivos, através da gestão territorial que assegure água e ar limpos, higidez ambiental, equipamentos coletivos urbanos, alimentos saudáveis e a disponibilidade de espaços naturais amenos urbanos, bem como da preservação de ecossistemas naturais." Herculano (1998, p.77-99) 
O desenvolvimento local caminha paralelo a era urbana, enquanto cidades ou megacidades surgem em cenários recentes de desenvolvimento econômico, como Xangai na China e Joanesburgo na África do Sul, ou mesmo cidades que são complexas há muito tempo, como Nova lorque, Londres e Berlim, ou ainda São Paulo e Cidade do México com seus milhões de habitantes. Todas compõem um cenário mundial de uma era urbana, onde cada uma delas têm problemas específicos, seu próprio conjunto de consequências sociais, econômicas e ambientais, além de formas diferentes: compacta, verticalizada, horizontal, hiperdensa, espalhada, dispersa, informal ou não planejada.

Porém, pode-se eleger o desenvolvimento local como um traço comum que pode ser usado em todas as cidades. Por exemplo, recuperar bairros debilitados, é uma tarefa que exige tempo, paciência, imaginação, habilidades e recursos. Compartilhar exemplos de soluções que deram certo, pode encurtar caminhos para outras iniciativas. Percebe-se que há iniciativas neste sentido de várias entidades, consórcios, conferências e encontros.

Ainda citanto ações locais de recuperação de áreas ou bairros destas grandes cidades, pode acontecer a instalação de uma empresa de alta tecnologia num local improvavél, por exemplo, e a partir daí, o transporte público melhora, habitações com mais qualidade começam a surgir, serviços sociais que antes eram escassos ou algum equipamento cultural pode incrementar estas revitalizações. As soluções são complexas e específicas para cada cidade, mas ações locais que tornam a cidade mais inclusiva são bons exemplos.

\subsubsection{A Gestão Local}

A dinâmica e a complexidade dos sistemas sociais modernos exigem caminhos de gestão novos. Muitas administrações continuam agindo como se nada tivesse mudado, com privilégios, propinas, nomeações, etc.

Os que tomam iniciativas de outras experiências muitas vezes não têm prática, conhecimento necessário ou sistemas de avaliação. É necessário que se forme um ambiente de transparência. Os objetivos devem ser mais do que físicos. Devem trazer mudanças sociais e mobilizar comunidades antes passivas.

Gestão social é muito mais saber ouvir e interagir que saber mandar e empurrar. A aprendizagem da gestão social é lenta. Encontra-se a esperança utópica em muitos embriões de renovação social. O resgate da cidadania e a descoberta do "fazer junto" trazem a solidariedade social.

Precisa-se reverter a idéia de que o dinheiro aplicado na indústria é investimento e no social é gasto, pois é investimento no ser humano com grande 
retorno em produtividade social. As atividades sociais são capilares. A saúde tem que chegar a cada uma das 40 milhões de crianças no Brasil. Por isso a importância da valorização da gestão local.

Spinik (2002, p. 57), identificou pontos em comum entre as boas experiências:

- A existência das articulações sociais integra parcerias de diversos tipos. Sempre há decisão conjunta e participativa;

- Busca de equilíbrio entre os interesses em jogo;

- Orientação por resultados;

- Busca de identificação do eixo crítico das atividades que se quer dinamizar;

- A tendência do terceiro setor não ter um papel substantivo;

- A importância de material de apoio de organização da gestão social;

- A utilização dos recursos de Tecnologia da Informação como facilitador da transparência;

- Um avanço, mesmo que pequeno, nas relações internacionais das prefeituras.

Spinik (2002, p. 60), sugere que se incentive a abertura por parte das administrações para a inovação, as novas formas de organização, para outras regiões e para o mundo.

\subsubsection{Participação e representação popular}

Costuma-se confundir democracia com atendimento às necessidades dos mais pobres. As experiências de participação mostram que é possível a descentralização administrativa e decisória, a valorização do funcionário público e o planejamento com o cidadão.

No caso do orçamento participativo vê-se um desempenho residual de pequenas verbas. Mesmo sendo difícil a implantação de mecanismos mais amplos de elaboração de políticas públicas, é fundamental a participação da comunidade da população que se beneficiará com o processo.

Governos conservadores têm adotado gestões participativas de alcance limitado para garantir uma boa imagem pública. Mesmo prefeitos que se identificam com as demandas sociais têm resistência em adotar tais políticas adotando programas com resultados mais imediatos (socorros assistencialistas).

Confunde-se bom governo com a execução de políticas para os pobres. É necessário reconhecer que é fundamental a ação coletiva dos cidadãos de uma sociedade. O orçamento participativo que se tem visto, tem pouca participação, pouco orçamento e seus compromissos nem sempre são cumpridos. 
Não se pode esperar também que pessoas omissas, passem a atuar em pé de igualdade com os representantes governamentais. Mesmo assim, a grande maioria das prefeituras criou os conselhos exigidos na constituição e muitos funcionam bem.

Quando analisados, alguns exemplos de casos de sucesso, pode-se afirmar que grande parte das iniciativas não se transformaram em políticas que asseguram efetivamente o direito dos cidadãos. Porém, percebe-se que há transformações tanto no Estado quanto na sociedade. Com a crescente presença dos governos na forma eletrônica, torna-se mais fácil estabelecer canais de comunicação.

Muitas das conquistas de um governo democrático são extintas no governo que o sucede, por isso, para garanti-las é necessário o envolvimento de entidades da sociedade civil.

Para fortalecer os governos locais são necessárias algumas medidas:

- ruptura com o uso privado dos recursos públicos;

- descentralizar o governo municipal e criar mecanismos de participação é uma forma de inclusão social, socialização do poder e eficiência na prestação de serviços públicos.

Não existem fronteiras definidas entre as atribuições do Estado e as iniciativas da sociedade civil. Elas são resultados de negociações.

Para Spinik (2002, p. 28), é necessário aproximar eleitor e eleito e articular três funções essenciais: a participação, a deliberação e a representação.

Talvez o maior desafio seja o de descentralizar o governo que pode ser através de subprefeituras com orçamento próprio e que promovam a negociação com as forças locais, segundo suas características aspirações e demandas.

Também é necessário valorizar o funcionário público com motivação, capacitação e reconhecimento de método.

Como sugestão de estímulo à participação, Spinik (2002, p. 39), pode-se trazer a implementação de um congresso da cidade com debates anuais sobre a cidade que queremos e os conselhos representantes, onde os conselheiros seriam eleitos localmente e, por um lado expressariam as demandas da população, e, por outro lado, debateriam com esta população os resultados das ações administrativas avaliando a eficácia das políticas públicas.

Conforme discutido no capítulo 3, o incremento das TICs nas administrações públicas, encontram-se em fase de grande expansibilidade, prestando serviços à população de forma cada fez mais inéditas. O cidadão pode, da comodidade de sua casa, clicar no site de uma prefeitura e baixar formulários, pagar tributos e principalmente opinar na administração. A facilidade de comunicação através do 
governo eletrônico, acelerou o processo de participação popular nas gestões e como os serviços disponíveis on line estão aumentando cada vez mais, pode-se ter também, inúmeros acréscimos de participação popular.

\subsubsection{A Experiência de Participação Popular na cidade de}

São Bernardo do Campo - SP

"A Constituição Federal de 1998 estabelece que os municípios, o Estado e a União elaborem três instrumentos de planejamento orçamentário - o PPA (Plano Plurianual), a LDO (Lei de Diretrizes Orçamentárias) e a LOA (Lei Orçamentária Anual). A função do PPA é nortear as ações específicas do poder público para os próximos quatro anos e será feito no ano de 2009, em São Bernardo do Campo, de forma participativa." Fonte: folheto explicativo distribuído pela prefeitura em abril de 2009.

A Prefeitura do município de São Bernardo do Campo, na atual gestão do Prefeito Luiz Marinho, começou a convocar a população para plenárias para a construção do Plano Plurianual - PPA. A prefeitura usou vários meios de divulgação para a convocação: site do município, distribuiu folhetos em residências, colocou faixas nas ruas, outdoors e circulou um carro de som pelo bairro no dia da plenária.

Dividiu-se a cidade em 29 regiões e para cada uma delas, foi agendado o dia da plenária. Os horários marcados foram às 18:30 quando durante a semana e às 9:00 hrs quando aos sábados. Participei da plenária do bairro em que moro no dia 11/05/2009 e a seguir apresento os detalhes que observei.

Um grande número de funcionários da Prefeitura trabalhou no local. Equipados com vários notebooks fizeram o cadastramento do munícipe coletando nome, endereço e telefone. Em seguida emitiram um cartão para os cadastrados e uma pulseira colorida foi dada aos cidadãos.

Havia um auditório montado com cadeiras para a população, caixas de som, telão e uma mesa principal para o Prefeito, Secretários e Agentes do Governo. Assim que foram chamados os integrantes da mesa, o Prefeito iniciou um discurso resumindo as ações por área de governo: saúde, habitação, educação, segurança e obras em andamento.

Durante toda a apresentação, havia uma tradutora para deficientes auditivos que estavam presentes e vieram de uma escola especial da região. Ainda no início, foi apresentado um vídeo explicativo sobre o PPA. Logo após, os técnicos da prefeitura fizeram um convite aos presentes que quisessem se candidatar e ser o representante da região. Qualquer pessoa poderia se candidatar, desde que fosse morador de um dos bairros componentes da região e que não trabalhasse na prefeitura. Ao todo nesta 
plenária candidataram-se 7 pessoas que tiveram 02 minutos cada, para se apresentarem e dizerem porque eram candidatos. Em seguida as pessoas foram divididas em grupos de discussão de acordo com a cor da pulseira, cerca de 10 grupos. Cada grupo foi orientado por um técnico da prefeitura que explicou as divisões por marca de governo, escolhida uma marca por votação, escolhiam-se dentro da marca, uma área para ser discutida. O grupo em que eu fazia parte, escolheu a educação. Dois subgrupos organizaram-se em círculo e debateram sobre o que achavam necessário melhorar naquela área. Depois, as sugestões foram escritas num painel e em seguida por votação foram escolhidas apenas 2 sugestões, que encaminhadas para a equipe do governo, posteriormente irão compor o documento do PPA.

Após a reunião dos grupos de discussão, todos foram convocados à votação eletrônica para os candidatos anteriormente apresentados. Em seguida, retornou-se para o auditório onde o Prefeito ouviu sugestões de pessoas num microfone montado para tal. Após responder a cada uma das sugestões, foi divulgado o resultado do candidato eleito a representante popular.

Estes 29 representantes que serão eleitos no período de 27 de abril de 2009 a 01 de junho de 2009 vão compor a Comissão de Acompanhamento do PPA, onde serão consolidadas as diretrizes. O texto final será enviado à Câmara Municipal para apreciação e votação dos vereadores.

O PPA é um importante instrumento de planejamento que, transformado em lei, orienta os gestores públicos na execução dos gastos e na aplicação dos investimentos. A importância desta peça orçamentária é que o governante fica vinculado a esse compromisso, sendo que só poderá ser realizada qualquer ação governamental se estiver estipulada no PPA.

“ Um governo pode fazer muita coisa sozinho, mas com a participação popular poderá fazer muito mais. O gestor público não deve ter medo desta participação" Prefeito Luiz Marinho, no final da plenária da Região 3 (Rudge Ramos) em 11/05/2009. 


\section{TRAJETÓRIA METODOLÓGICA}

\subsection{INTRODUÇÃO}

A metodologia adotada para esta dissertação, tem como objetivo selecionar as melhores práticas de Análise Espacial através de Sistema de Informação Geográfica na administração pública, a fim de se discutir sobre os benefícios dos projetos de SIG em municípios brasileiros. Procurou-se identificar quais cidades já dispunham um SIG implantado e em funcionamento. Através de uma análise dos principais itens encontrados no projeto do município, avaliou-se o desenvolvimento nesta área, identificando fortalezas, condições de sucesso, pontos de fraqueza, alcance, benefícios, etc.

Procurou-se citar também, alguns casos de sucesso no mundo, a fim de se comparar o avanço do Brasil em relação a outros países. O estudo com SIGs fora do Brasil, procurou analisar cidades com relevância em contextos nacionais ou regionais, foi tratada de forma simplificada, sem o envio de questionários, observados apenas por consulta a sites com o objetivo único de relacionar com o estágio de desenvolvimento brasileiro.

Os critérios de análise das cidades ou órgãos públicos tiveram o enfoque em informações georreferenciadas e Sistemas de Informações Geográficas que possibilitaram aos gestores a análise espacial para aplicação de políticas públicas que contribuíram para a melhora da qualidade de vida e serviços prestados, estando disponíveis para a população, através de sites ou outro meio de governo eletrônico.

Uma vez identificado o município com o SIG implantado ou em desenvolvimento, analisou-se qualitativamente o projeto e o sítios governamentais através de entrevistas ao órgão, ou prefeitura, com a elaboração de um questionário via email, que apurou os avanços na área. Vez ou outra se fez necessário uma entrevista por telefone ou presencial para esclarecer dúvidas. As entrevistas foram estruturadas, mas relativamente abertas e procuramos identificar:

- Nível de estratégia do governo para aplicação de um projeto de SIG;

- Processos organizacionais;

- Recursos humanos;

- Suporte das TICs;

- Grau de utilização de cartografia e informação georreferenciada;

- Alcance;

- Tipo de usuário, entre outros. 
Tentamos ainda, avaliar a utilização da Internet com relação a seu estágio de desenvolvimento: presencial, interativo, transacional e transformador. Também os serviços oferecidos, nível de divulgação e participação popular. Não se levou em consideração o tamanho do município.

Os questionários enviados e respondidos integram o Anexo I. As conclusões foram estruturadas sobre a forma de quadros sínteses, analisados, chegando-se às Considerações Finais.

\subsection{FASES DA PESQUISA}

\subsubsection{Primeira fase:}

Realizou-se uma revisão da literatura sobre os principais conceitos em geotecnologias, usos e aplicações. Identificou-se classificações mundiais sobre os estágios do Governo Eletrônico (presença, interação, transação e transformação) com base nas Leis e Diretrizes do programa brasileiro de governo eletrônico. A mesma classificação usada por outros organismos como a ONU, além de políticas de e-gov e aplicações. Elaborou-se um apanhado geral sobre a gestão de cidades, novos paradigmas no urbanismo, principais conceitos que estão sendo discutidos nos dias de hoje.

Esta primeira fase forneceu a base teórica do trabalho e proporcionou o questionamento sobre o que procurar nas administrações públicas pesquisadas, principalmente com relação à novas tecnologias e avanços nos serviços para os cidadãos.

\subsubsection{Segunda fase:}

Nesta fase foram enviados por email, questionários criados para se obter um panorama dos Estados sobre as iniciativas em geotecnologias. Considerando que as agências estaduais de socialização da informação - ASIs, são responsáveis pela tecnologia de informação e comunicação em cada estado, esse questionário pretende analisar e identificar casos relevantes e o comprometimento do governo estadual no direcionamento dos municípios para uma padronização de serviços de Sistemas de Informações Geográficas desenvolvidos ou em desenvolvimento.

Modelo de questionário enviado às ASIs: 
Questionário nº 01

ASls - Agências de Sociabilização da Informação

1) Existe alguma iniciativa de gerenciamento de informações espaciais ou georreferenciadas no estado?

2) Existe algum grupo de trabalho que tem a incumbência de formular normas e padronização de sistemas de geoprocessamento para órgãos públicos ou prefeituras?

3) Existem projetos de geoprocessamento no Estado?

4) O Governo Federal lançou em 27/11/08 o Decreto № 6.666 que institui a Infraestrutura Nacional de Dados Espaciais (INDE), para um cadastro único nacional de banco de dados geoespaciais, a ser implantado pelo IBGE/Concar, qual é a posição da Agência para este assunto?

5) Existe conhecimento de municípios que tem SIG (Sistema de Informações Geográficas) funcionando em qualquer área, (segurança, educação, saúde etc.) e quais destes municípios que disponibilizam aplicações de SIG em site de governo eletrônico.

6) Como acreditam que o governo-eletrônico possa ser potencializado com aplicações de geoprocessamento?

\section{Quantidade: 25 Agências estaduais}

Período: Abril e Maio / 2009

Quadro 24 - Questionário - modelo 01 - Enviado às Agëncias de Sociabilização da Informação - ASIs

Além das ASls, alguns órgãos, na esfera federal, considerados importantes pelo fornecimento de informação geográfica ou pela coordenação de políticas, foram também submetidos a questionamentos sobre andamento de projetos de SIG pelo país. São eles: INPE, IBGE, Ministério das Cidades, Comitê Executivo de Governo Eletrônico - CEGE do Ministério do Planejamento e Divisão de Cartografia - DICAR do Ministério da Defesa.

Questionário enviado aos Institutos: 
Questionário $n^{\circ} 02$

IBGE - INPE

1. Existe algum levantamento sobre os municípios brasileiros que possuem Sistemas de Informações Geográficas - SIG, se sim, qual é o cenário nacional de desenvolvimento nesta área? Se houver conhecimento, favor citar municípios que tem projetos relevantes de SIG.

2. No que o Instituto pode contribuir para trabalhos de Sistema de Informações Geográficas? Mapeamentos, softwares, apoio técnico, apoio legal e normativo?

3. O Governo Federal lançou em $27 / 11 / 08$ o Decreto $n^{0} 6.666$ que institui a Infraestrutura Nacional de Dados Espaciais (INDE), para um cadastro único nacional de banco de dados geoespaciais, a ser implantado pelo IBGE/Concar, que resultará na criação de um portal chamado SIG Brasil, qual é a fase atual de ações que o Instituto está realizando neste sentido?

4. O que o Instituto considera que irá melhorar para as administrações públicas com a implantação do SIG Brasil? E para os cidadãos?

\section{Quantidade: 02 Institutos}

Período: Abril e Maio / 2009

Quadro 25 - Questionário - modelo 02 - Enviado ao IBGE e INPE

A seguir, questionário enviado aos Ministérios abaixo relacionados:

\section{Questionário $n^{\circ} 03$}

\section{Ministério das Cidades}

1 - Assim como o Ministério das Cidades orientou os municípios para o Plano Diretor Participativo, existe ou poderá existir alguma orientação para projetos de Sistemas de Informações Geográficas - SIG municipais, uma vez que também são instrumentos que melhoram a qualidade da gestão municipal?

2 - Existe algum levantamento sobre municípios brasileiros que possuem SIG, se sim, qual é o cenário nacional de desenvolvimento nesta área?

3 - Quais são os objetivos do GeoSnic?

4 - Quais são as diretrizes da exigência para os municípios terem um Cadastro Técnico Municipal digital até 2.014?

3 - O Governo Federal lançou em 27/11/08 o Decreto o 6.666 que institui a Infra-estrutura Nacional de Dados Espaciais (INDE), para um cadastro único nacional de banco de dados geoespaciais, a ser implantado pelo IBGE/Concar, com quais ações o Ministério das Cidades poderá contribuir neste sentido? 
4 - O que o órgão considera que irá melhorar para as administrações públicas com a implantação do SIG Brasil? E para os cidadãos?

5 - Considerando a participação popular uma condição de melhora do processo democrático das gestões públicas, diversos canais de comunicação podem surgir: por exemplo as audiências públicas. Para o Ministério das Cidades a presença de sites governamentais favorecem a comunicação entre governo e cidadãos ? E o que poderia ser melhorado nesta comunicação?

Quantidade: 01

Quadro 26 - Questionário - modelo 03 - Enviado ao Ministério das Cidades

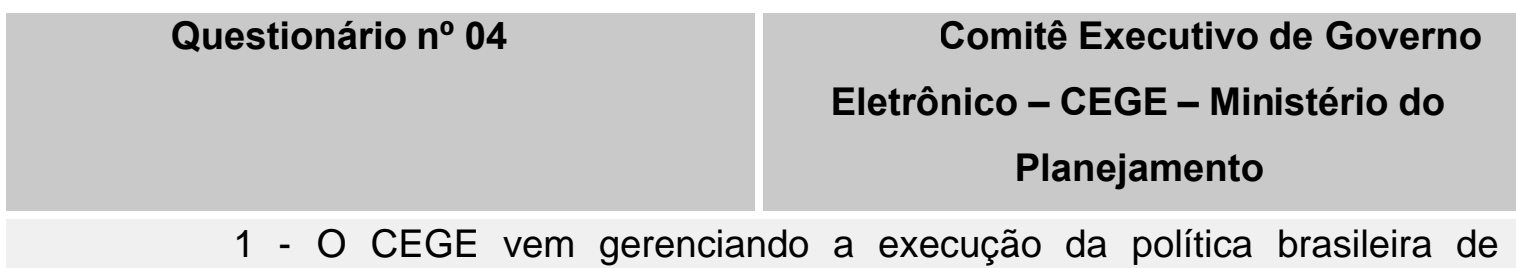

Governo Eletrônico, existe alguma orientação que inclua geotecnologias no Governo Eletrônico?

2 - A componente espacial no Governo Eletrônico, pode potencializar diversos serviços oferecidos a cidadãos e empresas, além de otimizar processos entre governos que conseguem ter uma visão mais abrangente do território. Existe algum levantamento sobre municípios ou órgãos brasileiros que possuem Sistemas de Informações Geográficas, se sim, qual é o cenário nacional de desenvolvimento nesta área?

3 - O Governo Federal lançou em 27/11/08 o Decreto ํo 6.666 que institui a Infra-estrutura Nacional de Dados Espaciais (INDE), para um cadastro único nacional de banco de dados geoespaciais, a ser implantado pelo IBGE/Concar, que resultará na implantação de um portal chamado SIG Brasil, qual é a opinião do CEGE a respeito?

4 - O que o Comitê considera que irá melhorar no âmbito do governo eletrônico com a implantação do SIG Brasil? E para os cidadãos?

\section{Quantidade: 01}

Período: Abril e Maio / 2009

Quadro 27 - Questionário - modelo 04 - Enviado ao Comitê Executivo de Governo Eletrônico - CEGE - do Ministério do Planejamento 
Questionário nº5

Divisão de Cartografia - DICAR

Ministério da Defesa

1 - O Ministério da Defesa, vem gerenciando os levantamentos aerofotogramétricos que existem no território brasileiro, existe alguma orientação que inclua aplicação de geotecnologias nestes levantamentos?

2 - Existe algum grupo de trabalho ou Divisão que tem a incumbência de formular normas e padronização para o uso de sistemas de geoprocessamento para órgãos públicos ou prefeituras?

3 - Quando uma agência de governo ou prefeitura torna público os mapeamentos do território através de sítios na Internet, disponibilizando mapas e bancos de dados de informação, como o Ministério da Defesa se posiciona perante a questão da segurança das informações territoriais?

4 - Existe algum levantamento no Ministério sobre municípios ou órgãos brasileiros que possuem Sistemas de Informações Geográficas, se sim, qual é o cenário nacional de desenvolvimento nesta área? E quanto a iniciativas em outros países, existe alguma comparação sobre o desenvolvimento brasileiro e de outros países?

5 - O Governo Federal lançou em 27/11/08 o Decreto no 6.666 que institui a Infra-estrutura Nacional de Dados Espaciais (INDE), para um cadastro único nacional de banco de dados geoespaciais, a ser implantado pelo IBGE/Concar, que resultará na implantação de um portal chamado SIG Brasil, qual é a opinião do Ministério da Defesa a respeito?

\section{Quantidade: $01 \quad$ Período: junho / 2009}

Quadro 28 - Questionário - modelo 05 - Enviado à Divisão de Cartografia - DICAR do Ministério da Defesa
}

Depois de um inventário sobre algumas boas práticas em todo o território, foram analisados os conteúdos dos projetos SIG, também através de questionários por email diretamente ao município escolhido. Independentemente das respostas das agências nacionais e estaduais, foram enviados questionários às 25 capitais estaduais. 


\section{Questionário nº6}

\section{MUNICÍPIOS}

1 - Quando o projeto começou? Quanto tempo está em uso?

2 - Quais entidades, órgãos ou secretarias envolvidas?

3 - Houve parceria com empresa privada?

4 - Qual foi o histórico do trabalho com relação às bases cartográficas, banco de dados, softwares e equipe envolvida?

5 - Qual é o objetivo principal do trabalho?

6 - Quais são os produtos finais gerados?

7 - O SIG está disponível em site governamental? Para qual categoria de usuários: cidadãos, empresas ou governo?

8 - Dentre as fases de desenvolvimento do governo-eletrônico, o projeto de SIG pode-se enquadrar nas seguintes categorias:

Presença: apenas disponíveis mapas de um determinado tema, com ferramentas simples de navegação como zoom in, out, pan, etc;

Interação: Permite ao usuário fazer buscas no mapa, dentro de um conjunto de perguntas e obter respostas on-line.

Transação: Permite ao usuário pagar on-line por uma determinada carta ou tema e fazer download da informação que precisa. Permite realizar buscas e a construção de cartas por tema.

Transformação: Permite ao usuário a construção de cartas on-line por composição de diversos temas inclusive com operações cartográficas complexas acessando várias fontes de dados de forma integrada.

Qual é a fase de desenvolvimento deste projeto?

9 - Qual a previsão de evolução deste projeto de SIG?

10 - Há participação popular? De que forma?

11- Quais os benefícios para a população?

12 - O Governo Federal lançou em 27/11/08 o Decreto № 6.666 que institui a Infra-estrutura Nacional de Dados Espaciais (INDE), para um cadastro único nacional de banco de dados geoespaciais, a ser implantado pelo IBGE/Concar, qual é a posição deste órgão para o assunto?

\section{Quantidade: 40 Municípios}

Período: Abril e Maio / 2009

Quadro 29 - Questionário - modelo 06 - Enviado aos municípios

Após a identificação dos casos mais relevantes através do questionário 06 , realizou-se uma análise crítica de todas as condições de implantação do Sistema 
de Informações Geográficas (proposta, softwares, pessoal envolvido, fontes de dados, metodologia de trabalho, sua interação com as diversas repartições ou órgãos envolvidos e resultados alcançados).

\subsubsection{Terceira fase:}

Nessa fase, foi elaborado um quadro comparativo, com as respostas das Agências Estaduais para se ter um panorama geral entre os estados e regiões brasileiras. Essa etapa foi importante para a tentativa de identificar uma estratégia nacional. Em seguida, foi realizada uma comparação entre os SIGs municipais, através das regiões brasileiras, numa tabela de itens presentes nos projetos relevantes que responderam aos questionários. Por fim, analisou-se os portais municipais que disponibilizam mapeamentos, informações georreferenciadas, análise espaciais ou SIGs interativos, numa tabela de funcionalidades com base nas fases de desenvolvimento de governo eletrônico, procurando-se identificar principalmente os níveis de participação popular e ou interação dos cidadãos com os sites.

Em resumo, a metodologia desenvolvida nesta pesquisa foi baseada na aplicação do esquema abaixo para se chegar às considerações finais:

Questionários sobre a realidade nacional e Quadro Resumo (abril e maio/09)

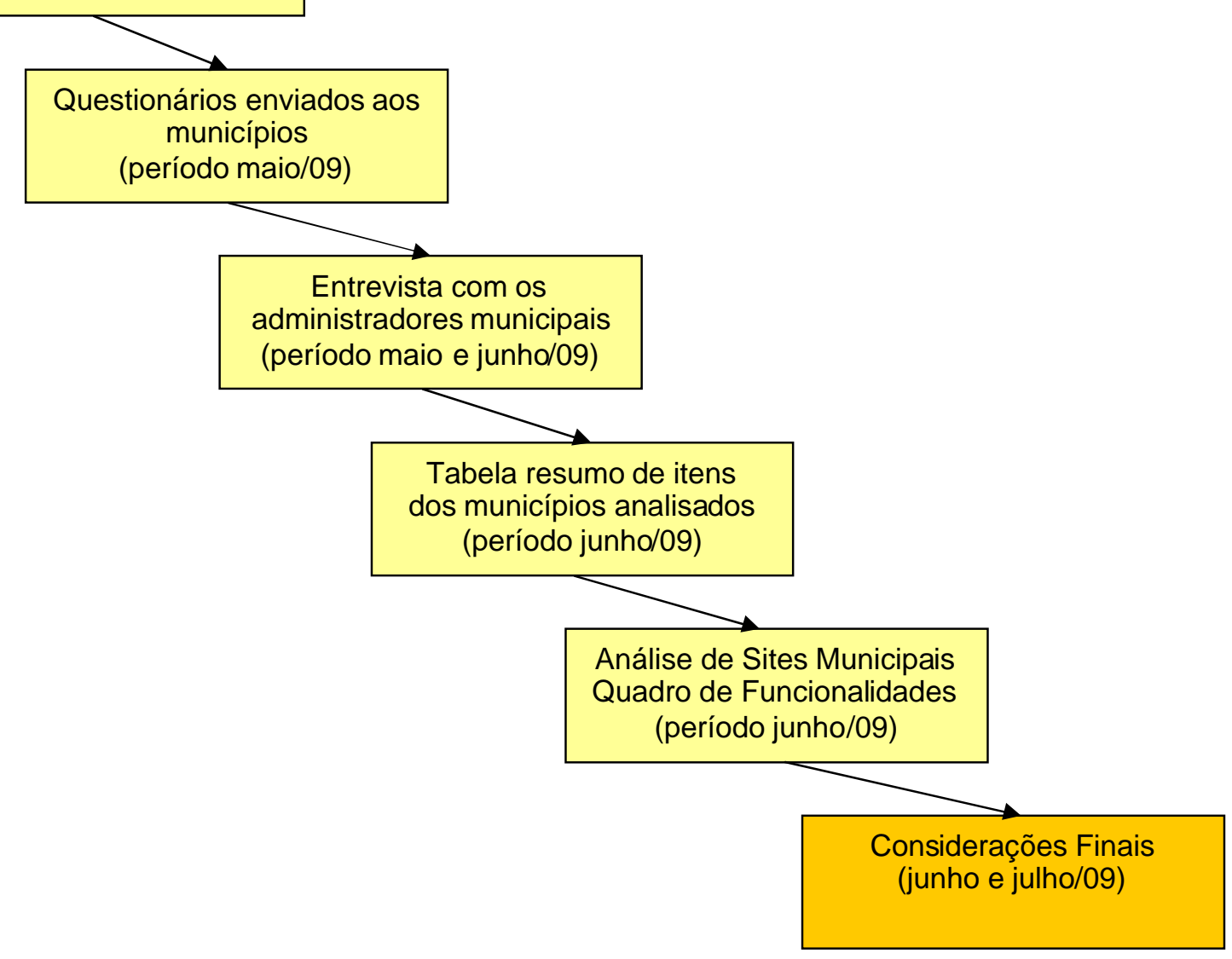


Figura ํํำ 01 - Esquema Metodológico

Salienta-se que não é o objetivo do trabalho levantar a existência de eserviços disponíveis nos sites municipais. Esse tipo de levantamento conduziria a pesquisa para outro caminho, com outra metodologia necessária.

Modelo do quadro comparativo sobre o direcionamento ou gerenciamento de Sistemas de Informações Geográficas nos governos estaduais.

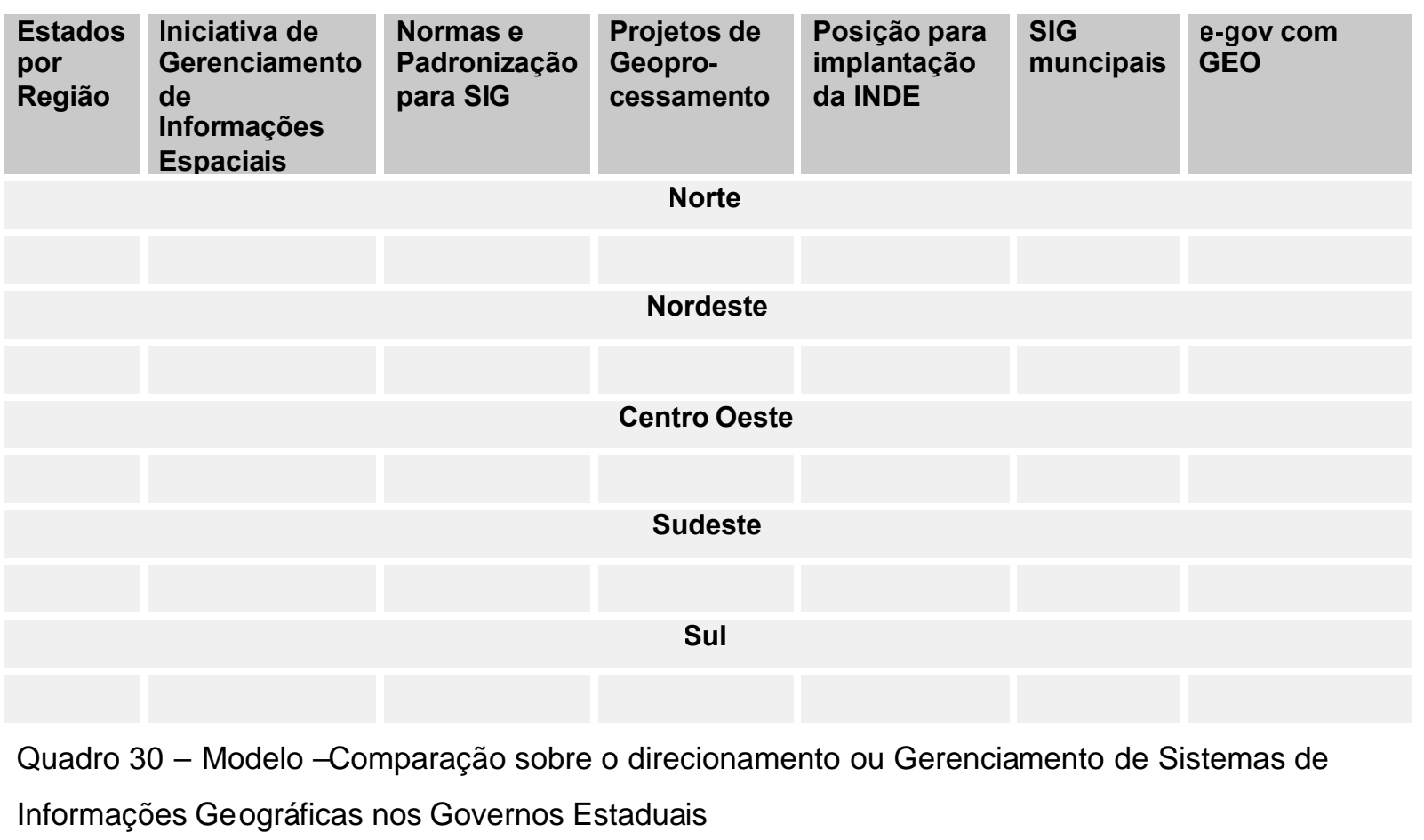

Quadro preenchido com base nas respostas do Questionário ํํ 1, enviados as Agências Estaduais de TI.

Modelo de Tabela de Itens para Avaliação dos Projetos de SIG Municipais: 


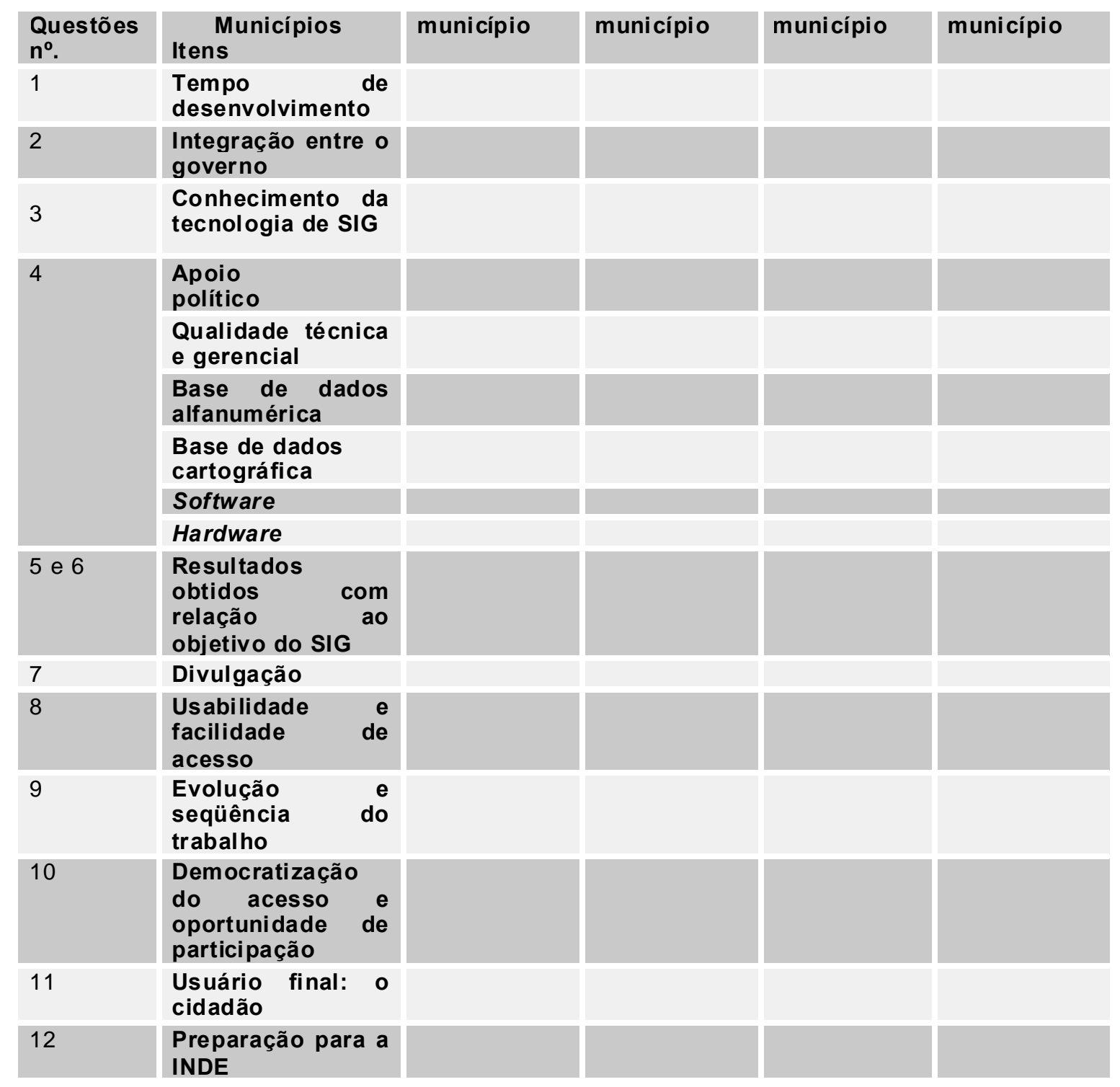

Quadro 31 - modelo - Itens para Avaliação dos Projetos de SIGs Municipais

Tabela preenchida com base no questionário ํo 06 enviado aos municípios e observados os fatores a seguir descritos, procurou-se analisar a qualidade dos projetos de SIG em funcionamento nos municípios, identificados através das entrevistas e questões enviadas:

- $\quad$ tempo de desenvolvimento: quando foi o início dos trabalhos e quanto tempo está em funcionamento, ou ainda, saber se o processo de implantação está em curso;

- $\quad$ integração entre o governo: identificar se todo o município participa, qual é o nível de integração entre os departamentos, se há integração de serviços, ações de reestruturação da administração, modernização, rotinas, redução de custos e benefícios obtidos. 
- $\quad$ conhecimento da tecnologia de SIG: deve-se buscar conhecimentos básicos do SIG, atualizar as informações conforme o desenvolvimento de novas tecnologias, potencialidades, treinamento para os usuários, tanto funcionários como para a equipe de gerenciamento, na maioria das vezes contar com consultoria externa;

- apoio político: a importância do empenho do poder executivo nos projetos de SIG para viabilizar as várias etapas, o reconhecimento de sua relevância, a capacidade de visão estratégica, ou seja, o apoio de uma liderança política.

- $\quad$ qualidade técnica e gerencial: a necessidade de uma equipe que conduza técnica e gerencialmente os trabalhos é de grande importância para que os resultados sejam sempre direcionados e avaliados nas suas principais etapas, com suporte tecnológico atualizado contínuo;

- $\quad$ base de dados alfanumérica: deve ser planejada de forma incremental permitindo o carregamento de novos dados na proporção e evolução dos aplicativos;

- base de dados cartográfica: deve ter a precisão necessária ao desenvolvimento dos trabalhos diversos que as secretarias demandam; a atualização deve ser incorporada na rotina administrativa de forma contínua;

- $\quad$ software: deve ser de fácil operação, versátil (integração com outros softwares), de custo compatível com o ambiente municipal e com escopo dos trabalhos a serem desenvolvidos;

- $\quad$ hardware: deve ser dimensionado para ter a capacidade suficiente na utilização dos diversos softwares e integração com periféricos; e ter um funcionamento em rede abrangendo toda a administração; haverá também a atualização dos equipamentos conforme as necessidades do usuário;

- $\quad$ resultados obtidos com relação ao objetivo do SIG: identificar se já foi alcançado o objetivo final do processo: a análise espacial do território para suporte aos tomadores de decisão, o compartilhamento de informações na administração, melhoria do serviço prestado à população, redução de custos e maior transparência das ações.

- divulgação: o SIG está disponível em site governamental para a população (cidadãos, empresas e governos). Como a tecnologia de SIG envolve experiências de aplicações recentes, é importante a divulgação dos resultados parciais e dos benefícios decorrentes. É importante também o intercâmbio das experiências acumuladas;

- $\quad$ usabilidade e facilidade de acesso: facilidade de localização dos mapas ou serviços, navegabilidade do sítio, acesso através de portal único. Identificar qual é 
a fase de desenvolvimento do SIG na Internet: presencial, interativo, transacional ou de transformação.

- $\quad$ evolução e seqüência do trabalho: identificar se existe previsão de evolução do projeto como um todo e na Internet, se permite a atualização constante das informações, desenvolvimento de aplicativos do SIG, demonstrar a eficácia e a eficiência da nova tecnologia na condução dos diversos serviços. A aplicação do SIG deve ser planejada de modo a propiciar resultados a curto prazo, a fim de demonstrar seus recursos e criar o comprometimento dos funcionários;

- $\quad$ democratização do acesso e oportunidade de participação: meios de acesso público: sites, quiosques eletrônicos, telefone, dispositivos móveis, informatização de espaços públicos. Meios para participação dos cidadãos e empresas através de audiências públicas, sites ou outros canais de comunicação.

- usuário final: o cidadão: amplitude social, interatividade, relevância, melhoria dos serviços prestados e a futurabilidade deste caminho.

- $\quad$ preparação para a INDE: o município está realizando alguma ação de preparo para a implantação da Infraestrutura nacional de dados espaciais.

Após esta análise crítica, comparou -se em outra tabela a avaliação dos SIGs em portais municipais, chegando-se assim às conclusões finais.

Modelo de Tabela de Avaliação de Sistemas de Informações Geográficas, disponíveis em portais municipais:

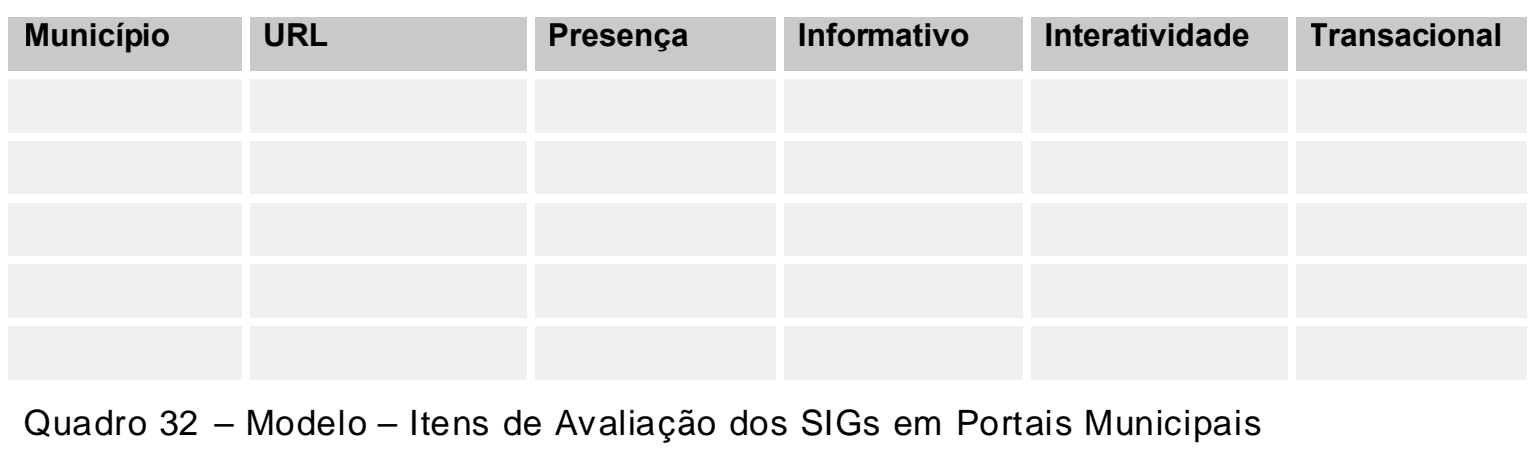

\subsubsection{Quarta fase - Final}

As Considerações Finais se deram pela análise dos seguintes dados: 
Universo da pesquisa

\begin{tabular}{|c|c|c|c|}
\hline & Universo & Mostra Final & $\begin{array}{l}\text { Questionários } \\
\text { Aplicados }\end{array}$ \\
\hline $\begin{array}{l}\text { Avaliação } \\
\text { Realidade } \\
\text { Nacional }\end{array}$ & $\begin{array}{l}25 \text { Agências } \\
\text { Estaduais } \\
02 \text { Institutos } \\
\text { Nacionais } \\
03 \text { Ministérios de } \\
\text { Governo }\end{array}$ & $\begin{array}{l}08 \text { respostas das } \\
\text { Agências Estaduais } \\
02 \text { respostas de } \\
\text { Institutos } \\
02 \text { respostas de } \\
\text { Ministérios }\end{array}$ & $\begin{array}{l}\text { Período de Abril à } \\
\text { Junho de } 2009\end{array}$ \\
\hline Entrevistas & $\begin{array}{lr}25 \text { Capitais de } \\
\text { Estado } & \\
15 & \text { Cidades } \\
\text { indicadas } & \text { pelas } \\
\text { Agências } & \end{array}$ & $\begin{array}{l}13 \text { Capitais } \\
04 \text { Cidades que } \\
\text { responderam }\end{array}$ & $\begin{array}{l}\text { Período de maio e } \\
\text { junho de } 2009\end{array}$ \\
\hline $\begin{array}{l}\text { Análises dos } \\
\text { Sítios Municipais }\end{array}$ & $\begin{array}{l}10 \text { municipios } \\
\text { nacionais } \\
10 \quad \text { municipios } \\
\text { internacionais }\end{array}$ & $\begin{array}{l}10 \text { informações } \\
\text { disponíveis } \\
\text { nacionais } \\
08 \text { informações } \\
\text { disponíveis } \\
\text { internacionais }\end{array}$ & $\begin{array}{l}\text { Período junho de } \\
2009\end{array}$ \\
\hline
\end{tabular}

Quadro 33 - Antecedentes Metodológicos do Desenvolvimento de SIGs Municipais

A conclusão levou em consideração principalmente a relação do governo com o cidadão. Procuramos responder às diversas questões que motivaram o trabalho: $O$ que realmente melhorou na prática? Quais os níveis de participação popular nas decisões? Quais as fraquezas e fortalezas dos projetos. Quais são as perspectivas para o futuro das novas relações dos cidadãos com as administrações municipais. Quais foram as contribuições desta pesquisa?

Houve uma tentativa de demonstrar quais projetos apresentam boas práticas de administração pública e que realmente resultam em mudanças democráticas nas estruturas do governo. 


\section{ANÁLISE DOS MUNICÍPIOS}

\subsection{INTRODUÇÃO}

Neste capítulo, as entrevistas serão analisadas e comentadas para que se possam fazer as Considerações Finais e assim o encerramento da pesquisa.

\subsection{RESULTADOS E DISCUSSÃO}

\subsection{1. Órgãos Nacionais}

Quadro sobre o direcionamento ou gerenciamento de Sistemas de Informações Geográficas nos governos estaduais.

\begin{tabular}{|c|c|c|c|c|c|c|}
\hline $\begin{array}{l}\text { Estados } \\
\text { por } \\
\text { Região }\end{array}$ & $\begin{array}{l}\text { Iniciativa de } \\
\text { Gerenciamento } \\
\text { de } \\
\text { Informações } \\
\text { Espaciais }\end{array}$ & $\begin{array}{l}\text { Normas e } \\
\text { Padronização } \\
\text { para SIG }\end{array}$ & $\begin{array}{l}\text { Projetos de } \\
\text { Geopro- } \\
\text { cessamento }\end{array}$ & $\begin{array}{l}\text { Posição para } \\
\text { implantação } \\
\text { da INDE }\end{array}$ & $\begin{array}{l}\text { SIG } \\
\text { muncipais }\end{array}$ & $\begin{array}{l}\text { e-gov com } \\
\text { GEO }\end{array}$ \\
\hline \multicolumn{7}{|c|}{ Norte } \\
\hline & Sem reposta & & & & & \\
\hline \multicolumn{7}{|c|}{ Nordeste } \\
\hline Ceará & $\begin{array}{l}\text { Sim, existe o } \\
\text { comitê de } \\
\text { geotecnologias }\end{array}$ & Sim & Sim & Favorável & Caucais & $\begin{array}{l}\text { Disponibilizand } \\
\text { o suas bases } \\
\mathrm{p} / \mathrm{a} \\
\text { comunidade }\end{array}$ \\
\hline \multicolumn{7}{|c|}{ Centro Oeste } \\
\hline Goiás & $\begin{array}{l}\text { Sim, uma } \\
\text { supervisão em } \\
\text { geoprocessam. }\end{array}$ & Não & Sim & $\begin{array}{l}\text { Não tem } \\
\text { conhecimento }\end{array}$ & Goiânia & $\begin{array}{l}\text { Sim de várias } \\
\text { formas }\end{array}$ \\
\hline $\begin{array}{l}\text { Mato } \\
\text { Grosso }\end{array}$ & Sim & Sim & Sim & $\begin{array}{l}\text { Sim tem um } \\
\text { grupo } \\
\text { específico }\end{array}$ & $\begin{array}{l}\text { Cuiabá } \\
\text { Várzea } \\
\text { Grande } \\
\text { Lucas do } \\
\text { Rio Verde }\end{array}$ & Sim \\
\hline \multicolumn{7}{|c|}{ Sudeste } \\
\hline $\begin{array}{l}\text { Espírito } \\
\text { Santo }\end{array}$ & $\begin{array}{l}\text { Sim, existe o } \\
\text { Geobases } \\
\text { desde } 1999\end{array}$ & $\begin{array}{l}\text { Sim, o } \\
\text { Geobases }\end{array}$ & Sim & $\begin{array}{l}\text { Estruturação } \\
\text { do Geobases } \\
\text { será } \\
\text { equiparada a } \\
\text { da INDE }\end{array}$ & $\begin{array}{l}\text { Sim, usam } \\
\text { o } \\
\text { Geobases }\end{array}$ & $\begin{array}{l}\text { Através do } \\
\text { Geobases on } \\
\text { line até dez } 09\end{array}$ \\
\hline $\begin{array}{l}\text { São } \\
\text { Paulo }\end{array}$ & Não & $\begin{array}{l}\text { Houve, mas ñ } \\
\text { evoluiu }\end{array}$ & Sim & Não & Não & Sim \\
\hline \multicolumn{7}{|c|}{ Sul } \\
\hline Paraná & $\begin{array}{l}\text { Sim, existiu e } \\
\text { não deu certo }\end{array}$ & Sim & Sim & Favorável & Curitiba & $\operatorname{sim}$ \\
\hline $\begin{array}{l}\text { Santa } \\
\text { Catarina }\end{array}$ & Sim & Sim & Sim & Não conhece & $\begin{array}{l}\text { Blumenau } \\
\text { Floripa } \\
\text { Criciúma } \\
\text { São José } \\
\text { Palhoça } \\
\text { Joinvile } \\
\text { Chapecó } \\
\text { Itapema } \\
\text { Itajaí }\end{array}$ & $\begin{array}{l}\text { Sim, mas os } \\
\text { esforços são } \\
\text { dispersos }\end{array}$ \\
\hline $\begin{array}{l}\text { Rio } \\
\text { Grande } \\
\text { do Sul }\end{array}$ & $\begin{array}{l}\text { Sim, agricultura, } \\
\text { meio ambiente, } \\
\text { segurança, } \\
\text { saúde, etc. }\end{array}$ & $\begin{array}{l}\text { Sim na } \\
\text { Secretaria da } \\
\text { Agricultura }\end{array}$ & $\begin{array}{l}\text { Sim, ex. } \\
\text { controle de } \\
\text { sanidade } \\
\text { animal }\end{array}$ & $\begin{array}{l}\text { Não tem } \\
\text { orientação }\end{array}$ & Sim vários & $\begin{array}{l}\text { www.geolivre. } \\
\text {.rs.gov.br }\end{array}$ \\
\hline
\end{tabular}

Quadro 34 - Comparação sobre o direcionamento ou gerenciamento de SIGs nos Governos 
Com o resultado dos questionários enviados às Agências Estaduais e Órgãos Nacionais analisou-se que não existe um firme direcionamento na esfera federal para o desenvolvimento de um programa de governo ou estratégia nacional para o uso de geotecnologias, que conduza o país para o aproveitamento máximo dos recursos tecnológicos existentes hoje em dia. Como para o desenvolvimento do Governo Eletrônico no Brasil, houve a criação de Comitês específicos, legislação e diretrizes de desenvolvimento, percebe-se que no caso das geotecnologias, apesar de contarmos com os institutos de relevância internacional como o INPE e o IBGE, não há o mesmo empenho. Com a criação do Decreto sobre a criação da INDE, sabe-se que há um longo caminho a seguir. O Ministério das Cidades, não respondeu ao questionário, após inúmeras tentativas.

Os estados têm projetos diversos em andamento, porém sofrem com as mudanças políticas. Por exemplo, o Paraná, que tinha um projeto para um sistema cartográfico único no estado, mas que não teve continuidade na administração seguinte. Os estados deveriam ter ações em conjuntos direcionados através de legislação específica, mas não há. O Ministério das Cidades, por sua vez, poderia instruir os municípios a desenvolverem um SIG, como fizeram com o Plano Diretor. Talvez a criação do portal SIG Brasil que é citado no Decreto 6.666 de 28/11/08 trará uma visão ao governo para a necessidade de diretrizes na gestão de dados espaciais, tão fundamentais para aplicações de políticas públicas mais direcionadas.

Quanto ao contexto mundial, há várias iniciativas de Infraestruturas de Informações Geográficas. Na Europa a INSPIRE - Infraestrutura Européia de Informação Geográfica está em implantação desde 15/05/2007 e prevista a última etapa para 2013, pretende conduzir a serviços integrados de informação geográfica, disponibilidados através de um Geo Portal onde será possível pesquisar dados, serviços e organizações. Seus utilizadores serão os decisores políticos, gestores nacionais, locais, cidadãos e organizações. Existe um grau de sensibilização crescente na Europa para a necessidade de informação georreferenciada de qualidade, de suporte à compreensão da complexidade e das interações entre as atividades humanas e as pressões e impactos ambientais. Disponível em <http:///inspire.jrc.ec.europa.eu/> , acesso em 24/04/2009..

Na América do Sul, a IDE Argentina destaca-se, existindo lei específica, como a Lei Nacional de Cadastro, n 26.209 vigente desde 2006, há grupos de implantação nas províncias e uma coordenação que envolve várias instituições através do Instituto Geográfico Nacional, denominado projeto PROSIGA. Na Argentina, existe também, a revista IDE Iberoamérica com artigos do meio. 


\subsubsection{Municípios}

Tabela de itens para avaliação dos projetos de SIG municipais. A numeração das questões na primeira coluna, é correspondente à numeração do questionário.

Região Sudeste - Capitais Estaduais

\begin{tabular}{|c|c|c|c|c|c|}
\hline $\begin{array}{l}\text { Questões } \\
n^{\circ} \text {. }\end{array}$ & $\begin{array}{l}\text { Municípios } \\
\text { Itens }\end{array}$ & São Paulo & $\begin{array}{l}\text { Belo } \\
\text { Horizonte }\end{array}$ & $\begin{array}{ll}\text { Rio de } \\
\text { Janeiro }\end{array}$ & Vitória \\
\hline 1 & $\begin{array}{l}\text { Tempo de } \\
\text { desenvolvimento }\end{array}$ & $\begin{array}{l}\text { Final dos anos } \\
80 \text {, cerca de } 20 \\
\text { anos }\end{array}$ & 17 anos & $\begin{array}{l}\text { Inicio do anos } \\
90, \text { cerca de } \\
19 \text { anos }\end{array}$ & $\begin{array}{ll}\text { Início } & \text { em } \\
1998, & 11 \\
\text { anos } & \end{array}$ \\
\hline 2 & $\begin{array}{l}\text { Integração entre } \\
\text { o governo }\end{array}$ & $\begin{array}{l}\text { Todas as } \\
\text { secretarias }\end{array}$ & $\begin{array}{l}80 \% \quad \text { da } \\
\text { Prefeitura usa } \\
\text { dados georref. }\end{array}$ & $\begin{array}{l}\text { Todas as } \\
\text { secretarias }\end{array}$ & $\begin{array}{l}\text { Quase todas } \\
\text { as } \\
\text { secretarias }\end{array}$ \\
\hline 3 & $\begin{array}{l}\text { Conhecimento } \\
\text { da tecnologia de } \\
\text { SIG }\end{array}$ & $\begin{array}{l}\text { Tiveram } \\
\text { consultoria } \\
\text { externa }\end{array}$ & $\begin{array}{l}\text { Equipe interna } \\
\text { de } \\
\text { desenvolvimento }\end{array}$ & $\begin{array}{l}\text { Equipe interna } \\
\text { de } \\
\text { desenvolvimento }\end{array}$ & $\begin{array}{l}\text { Houve } \\
\text { contratação } \\
\text { alguns } \\
\text { serviços }\end{array}$ \\
\hline \multirow[t]{6}{*}{4} & $\begin{array}{l}\text { Apoio } \\
\text { político }\end{array}$ & Pouco & Sim & Sim & Sim \\
\hline & $\begin{array}{l}\text { Qualidade } \\
\text { técnica } \\
\text { gerencial }\end{array}$ & Sim & Sim & Sim & Sim \\
\hline & $\begin{array}{l}\text { Base de dados } \\
\text { alfanumérica }\end{array}$ & $\begin{array}{l}\text { Sim, mas não é } \\
\text { centralizada }\end{array}$ & $\begin{array}{l}\text { CTM bem } \\
\text { estruturado }\end{array}$ & Sim & Sim \\
\hline & $\begin{array}{l}\text { Base de dados } \\
\text { Cartográfica }\end{array}$ & Sim & Sim & Sim & Sim \\
\hline & Software & Diversos & $\begin{array}{l}\text { Oracle, } \\
\text { Geomedia e } \\
\text { Mapinfo }\end{array}$ & Não informado & $\begin{array}{l}\text { Não } \\
\text { informado }\end{array}$ \\
\hline & Hardware & $\begin{array}{l}\text { Sem } \\
\text { comentário }\end{array}$ & $\begin{array}{l}\text { Sem } \\
\text { comentário }\end{array}$ & $\begin{array}{l}\text { Sem } \\
\text { comentário }\end{array}$ & $\begin{array}{l}\text { Sem } \\
\text { comentário }\end{array}$ \\
\hline 5 e 6 & $\begin{array}{l}\text { Resultados } \\
\text { obtidos com } \\
\text { relação ao } \\
\text { objetivo do SIG }\end{array}$ & $\begin{array}{l}\text { Sim, diversas } \\
\text { análises } \\
\text { espaciais }\end{array}$ & $\begin{array}{l}\text { Sim, diversas } \\
\text { análises } \\
\text { espaciais }\end{array}$ & $\begin{array}{l}\text { Sim, } \\
\text { disseminar geo } \\
\text { informação e } \\
\text { apoiar } \\
\text { sistemas } \\
\text { corporativos }\end{array}$ & $\begin{array}{l}\text { Sim, } \\
\text { integração } \\
\text { entre as } \\
\text { secretarias e } \\
\text { suporte às } \\
\text { ações }\end{array}$ \\
\hline 7 & Divulgação & Sim & Não & Sim & Sim \\
\hline 8 & $\begin{array}{l}\text { Usabilidade } \\
\text { facilidade } \\
\text { acesso }\end{array}$ & Não & Só intranet & $\begin{array}{l}\text { Sim existência } \\
\text { de portal único }\end{array}$ & $\begin{array}{l}\text { Sim } \\
\text { existência de } \\
\text { portal único }\end{array}$ \\
\hline 9 & $\begin{array}{l}\text { Evolução } \\
\text { seqüencia } \\
\text { trabalho }\end{array}$ & $\begin{array}{l}\text { Evoluir a } \\
\text { apresentação } \\
\text { na Internet }\end{array}$ & $\begin{array}{l}\text { Em análise } \\
\text { para Internet } \\
\text { até final de } 09\end{array}$ & $\begin{array}{l}\text { Maior } \\
\text { integração } \\
\text { entre } \\
\text { sitemas }\end{array}$ & $\begin{array}{lr}\text { não têm } \\
\text { objetivo de } \\
\text { evoluir para } \\
\text { a ultima fase }\end{array}$ \\
\hline 10 & $\begin{array}{l}\text { Democratização } \\
\text { do acesso e } \\
\text { oportunidade de } \\
\text { participação }\end{array}$ & Sim & $\begin{array}{l}\text { Não por } \\
\text { enquanto }\end{array}$ & $\begin{array}{l}\text { Pouca } \\
\text { participação }\end{array}$ & Sim \\
\hline 11 & $\begin{array}{l}\text { Usuário final: o } \\
\text { cidadão }\end{array}$ & $\begin{array}{l}\text { Informação } \\
\text { disponível }\end{array}$ & $\begin{array}{l}\text { Informação } \\
\text { disponível }\end{array}$ & $\begin{array}{l}\text { Informação } \\
\text { disponível }\end{array}$ & $\begin{array}{l}\text { Informação } \\
\text { disponível }\end{array}$ \\
\hline 12 & $\begin{array}{l}\text { Preparação para } \\
\text { a INDE }\end{array}$ & Não há & Não há & Não há & Não há \\
\hline
\end{tabular}

Quadro 35 - Itens para Avaliação dos Projetos de SIGs Municipais na Região Sudeste - Capitais Estaduais 
Região Sudeste - Outras Cidades

\begin{tabular}{|c|c|c|c|c|c|}
\hline $\begin{array}{l}\text { Questões } \\
n^{\circ} \text {. }\end{array}$ & $\begin{array}{l}\text { Municípios } \\
\text { Itens }\end{array}$ & $\begin{array}{l}\text { São José } \\
\text { dos Campos } \\
\text { - SP }\end{array}$ & Santos - SP & $\begin{array}{l}\text { Santo André - } \\
\text { SP }\end{array}$ & Colatina -ES \\
\hline 1 & $\begin{array}{l}\text { Tempo de } \\
\text { desenvolvimento }\end{array}$ & $\begin{array}{l}\text { Desde } 1997 \\
-12 \text { anos }\end{array}$ & $\begin{array}{l}\text { Desde } 2002- \\
7 \text { anos }\end{array}$ & $\begin{array}{l}\text { Início em } 1990 \\
19 \text { anos }\end{array}$ & $\begin{array}{l}\text { Início em } \\
2006\end{array}$ \\
\hline 2 & $\begin{array}{l}\text { Integração entre } \\
\text { o governo }\end{array}$ & $\begin{array}{l}\text { Quase todas } \\
\text { secretarias }\end{array}$ & $\begin{array}{ll}\text { Todas } & \text { as } \\
\text { secretarias } & \end{array}$ & $\begin{array}{ll}\text { Todas } & \text { as } \\
\text { secretarias } & \end{array}$ & $\begin{array}{l}03 \\
\text { secretarias }\end{array}$ \\
\hline 3 & $\begin{array}{l}\text { Conhecimento } \\
\text { da tecnologia de } \\
\text { SIG }\end{array}$ & $\begin{array}{l}\text { Tiveram } \\
\text { consultoria } \\
\text { externa }\end{array}$ & $\begin{array}{l}\text { Equipe interna } \\
\text { de } \\
\text { desenvolvimento } \\
\text { e consultoria ext }\end{array}$ & $\begin{array}{l}\text { Equipe interna } \\
\text { de } \\
\text { desenvolvimento }\end{array}$ & $\begin{array}{l}\text { Tiveram } \\
\text { consultoria } \\
\text { externa }\end{array}$ \\
\hline \multirow[t]{6}{*}{4} & $\begin{array}{l}\text { Apoio } \\
\text { político }\end{array}$ & Pouco & Muito alto & Sim & Sim \\
\hline & $\begin{array}{l}\text { Qualidade } \\
\text { técnica } \\
\text { gerencial }\end{array}$ & $\operatorname{Sim}$ & Sim & Sim & Sim \\
\hline & $\begin{array}{l}\text { Base de dados } \\
\text { alfanumérica }\end{array}$ & $\begin{array}{l}\text { Trabalhando } \\
\text { p/unificação } \\
\text { do BD }\end{array}$ & $\begin{array}{l}\text { BD única e } \\
\text { confiável }\end{array}$ & $\begin{array}{l}\text { BD único e } \\
\text { bem atualizado }\end{array}$ & Sim \\
\hline & $\begin{array}{l}\text { Base de dados } \\
\text { cartográfica }\end{array}$ & Sim & Sim & Sim & Sim \\
\hline & Software & Diversos & $\begin{array}{l}\text { Terralib, } \\
\text { customizado e } \\
\text { Oracle BD }\end{array}$ & $\begin{array}{l}\text { Oracle } \mathrm{p} / \mathrm{BD} \text { e } \\
\text { Geomedia }\end{array}$ & Customizado \\
\hline & Hardware & $\begin{array}{l}\text { Sem } \\
\text { comentário }\end{array}$ & $\begin{array}{l}\text { Investimento } \\
\text { em } \\
\text { cabeamento } \\
\text { óptico em to da } \\
\text { a prefeitura e } \\
\text { em servidores }\end{array}$ & $\begin{array}{l}\text { Sem } \\
\text { comentário }\end{array}$ & $\begin{array}{l}\text { Sem } \\
\text { comentário }\end{array}$ \\
\hline 5 e 6 & $\begin{array}{l}\text { Resultados } \\
\text { obtidos com } \\
\text { relação ao } \\
\text { objetivo do SIG }\end{array}$ & $\begin{array}{l}\text { Por enquanto } \\
\text { é mais usado } \\
\text { para } \\
\text { consultas } \\
\text { simples. }\end{array}$ & $\begin{array}{l}\text { Sim, diversas } \\
\text { análises } \\
\text { espaciais em } \\
\text { todas } \\
\text { secretarias }\end{array}$ & $\begin{array}{l}\text { Sim, socializar } \\
\text { a informação e } \\
\text { publicar via } \\
\text { web ao público } \\
\text { agilizando } \\
\text { processos }\end{array}$ & $\begin{array}{l}\text { Sim, criar } \\
\text { ferramenta } \\
\text { para a } \\
\text { tomada de } \\
\text { decisão e } \\
\text { modernização } \\
\text { da } \\
\text { administração }\end{array}$ \\
\hline 7 & Divulgação & Pouca & Sim & pouca & verificar \\
\hline 8 & $\begin{array}{l}\text { Usabilidade e } \\
\text { facilidade } \\
\text { acesso }\end{array}$ & $\begin{array}{l}\text { Pouca, existe } \\
\text { mapas } \\
\text { na Internet } \\
\text { com poucos } \\
\text { recursos. }\end{array}$ & $\begin{array}{l}\text { Sim existência } \\
\text { de } \quad \text { portal } \\
\text { único, com } \\
\text { algumas } \\
\text { funções } \\
\end{array}$ & $\begin{array}{l}\text { Por enquanto } \\
\text { somente } \\
\text { consultas na } \\
\text { Geo Web de } \\
\text { quadras fiscais }\end{array}$ & \\
\hline 9 & $\begin{array}{lr}\text { Evolução } & \text { e } \\
\text { seqüência } & \text { do } \\
\text { trabalho } & \end{array}$ & $\begin{array}{l}\text { Evoluir para } \\
\text { apresentação } \\
\text { na internet }\end{array}$ & $\begin{array}{ll}\text { Evolução } & \text { do } \\
\text { Geo } & \text { na } \\
\text { Internet } & \end{array}$ & $\begin{array}{l}\text { Em desenv. } \\
\text { maisaplicações } \\
\text { para internet }\end{array}$ & \\
\hline 10 & $\begin{array}{l}\text { Democratização } \\
\text { do acesso e } \\
\text { oportunidade de } \\
\text { participação }\end{array}$ & $\begin{array}{l}\text { Pouca } \\
\text { participação }\end{array}$ & $\begin{array}{l}\text { Sim, com } \\
\text { audiências } \\
\text { públicas }\end{array}$ & Sim & \\
\hline 11 & $\begin{array}{l}\text { Usuário final: o } \\
\text { cidadão }\end{array}$ & $\begin{array}{l}\text { Informação } \\
\text { disponível }\end{array}$ & Amplo alcance & $\begin{array}{l}\text { Melhora do } \\
\text { atendimento }\end{array}$ & $\begin{array}{l}\text { Informação } \\
\text { disponível }\end{array}$ \\
\hline 12 & $\begin{array}{l}\text { Preparação para } \\
\text { a INDE }\end{array}$ & Não há & Não há & Não há & $\begin{array}{l}\text { BD modelado } \\
\text { para Open } \\
\text { Gls }\end{array}$ \\
\hline
\end{tabular}

Quadro 36 - Itens para avaliação dos Projetos de SIGs Municipais na Região Sudeste - Outras Cidades 
No caso da cidade de São Paulo, após a entrevista, identificou-se que o tamanho da máquina administrativa dificulta a implantação do geoprocessamento, vez que todos os departamentos fazem algum trabalho de SIG, sem uma coordenação única. Vários departamentos atualizam mapas, bancos de dados e geram produtos. Essa dificuldade de concentração é sentida no site do município, onde não se encontra um portal único de informações.

Exemplo dos inúmeros produtos disponíveis em site:

\section{Mapas e Dados}

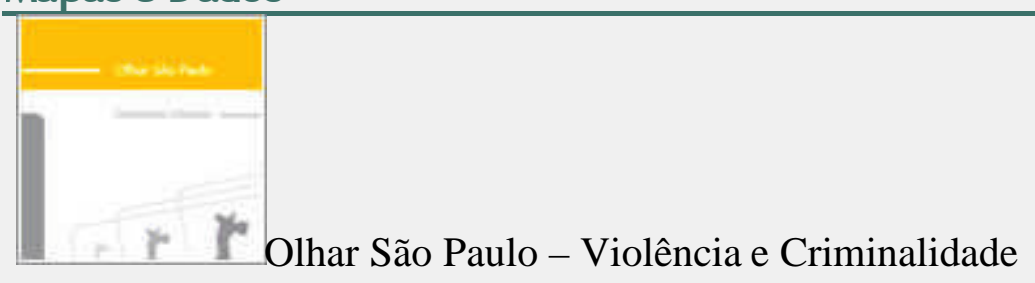

A relação entre o espaço urbano e o crime.

Acesse o site

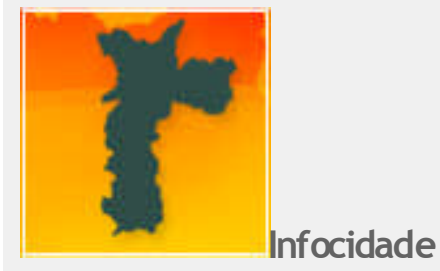

O novo endereço para consultas de dados sobre a cidade de São Paulo.

Acesse o site

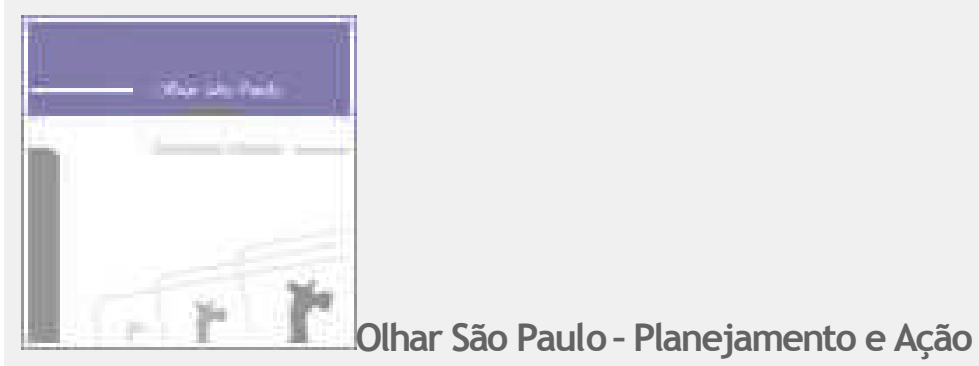

Acesse o site

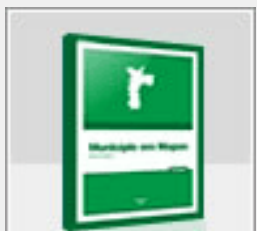

Município em Mapas 2008: Panorama

Este volume oferece uma visão geral sobre a cidade a partir de diversos aspectos: sociais, econômicos, ambientais e urbanísticos. 
Acesse o site

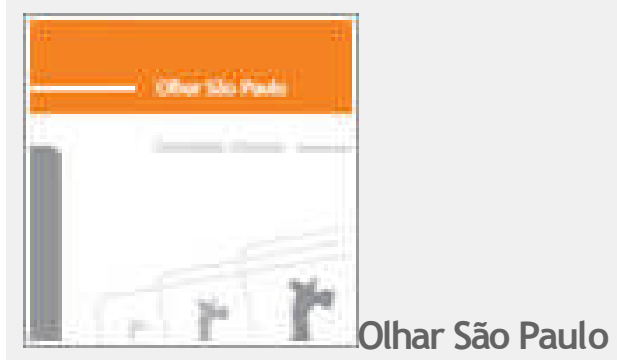

Um perfil da cidade e de seus contrastes.

Acesse o site

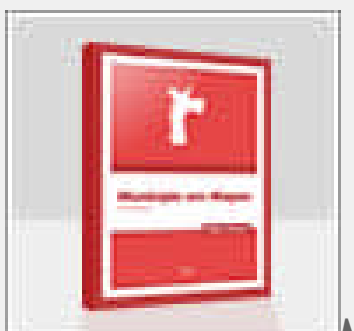

Município em Mapas 2007: Cultura e Território

Estudo traz mapeamento inédito de equipamentos culturais e economia da cultura no Município de São Paulo. Acesse o site

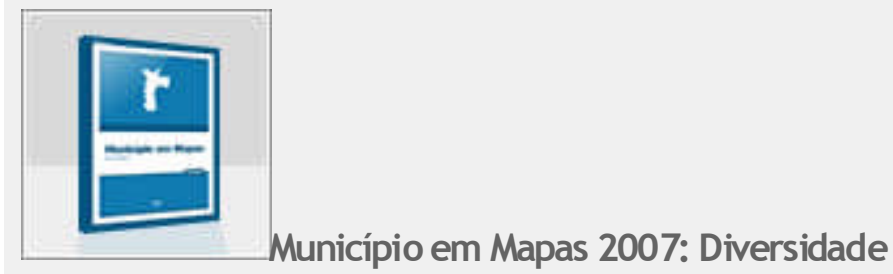

Um enfoque nas desigualdades de gênero, cor e geração.

Acesse o site

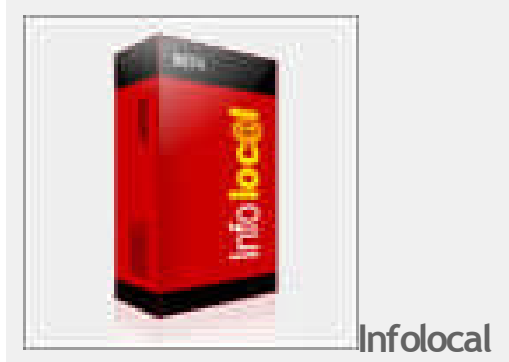

Sistema permite construir mapas e tabelas acessando toda a base de dados do Município de São Paulo. Veja mais $\mid \underline{\text { Acesse o site }}$ 
Histórico Demográfico

Viaje pela história do Município de São Paulo através de animações com mapas, fatos e fotos de época. Acesse também informações dos censos de 1872 até 2000 . Acesse o site

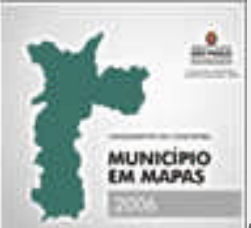

Município em Mapas 2006

Série traz análises e mapas temáticos sobre temas pertinentes ao cotidiano da cidade: Analfabetismo, Índices Sociais, Economia Urbana, Dinâmica Urbana.

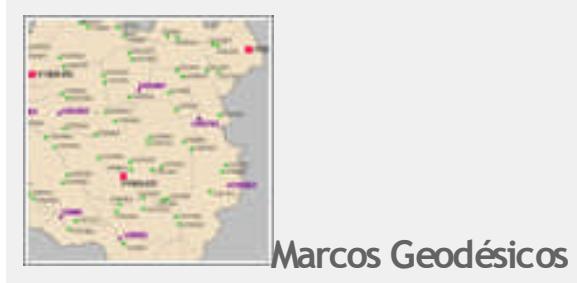

Acesse aqui

Quadro 37 - Site do Município de São Paulo - Link para Mapas e Dados

Ainda no município de São Paulo, percebe-se que há falta de uma política de Sistemas de Informações Geográficas, presente em várias gestões onde o projeto poderia estar muito mais desenvolvido, por exemplo, com ortofotos disponíveis com várias ferramentas SIG. Poderia também trabalhar em parceria com a Região Metropolitana, através do Governo do Estado para não haver desperdício de esforços e custos. Se existisse uma visão estratégica e se percebessem o quanto tornaria o Estado mais competitivo. A Fundação Seade, responsável pela Tecnologia de Informação e Comunicação no estado, não tem conhecimento sobre os municípios que têm SIG, não gerencia banco de informações e não tem política voltada para dados georreferenciados. 


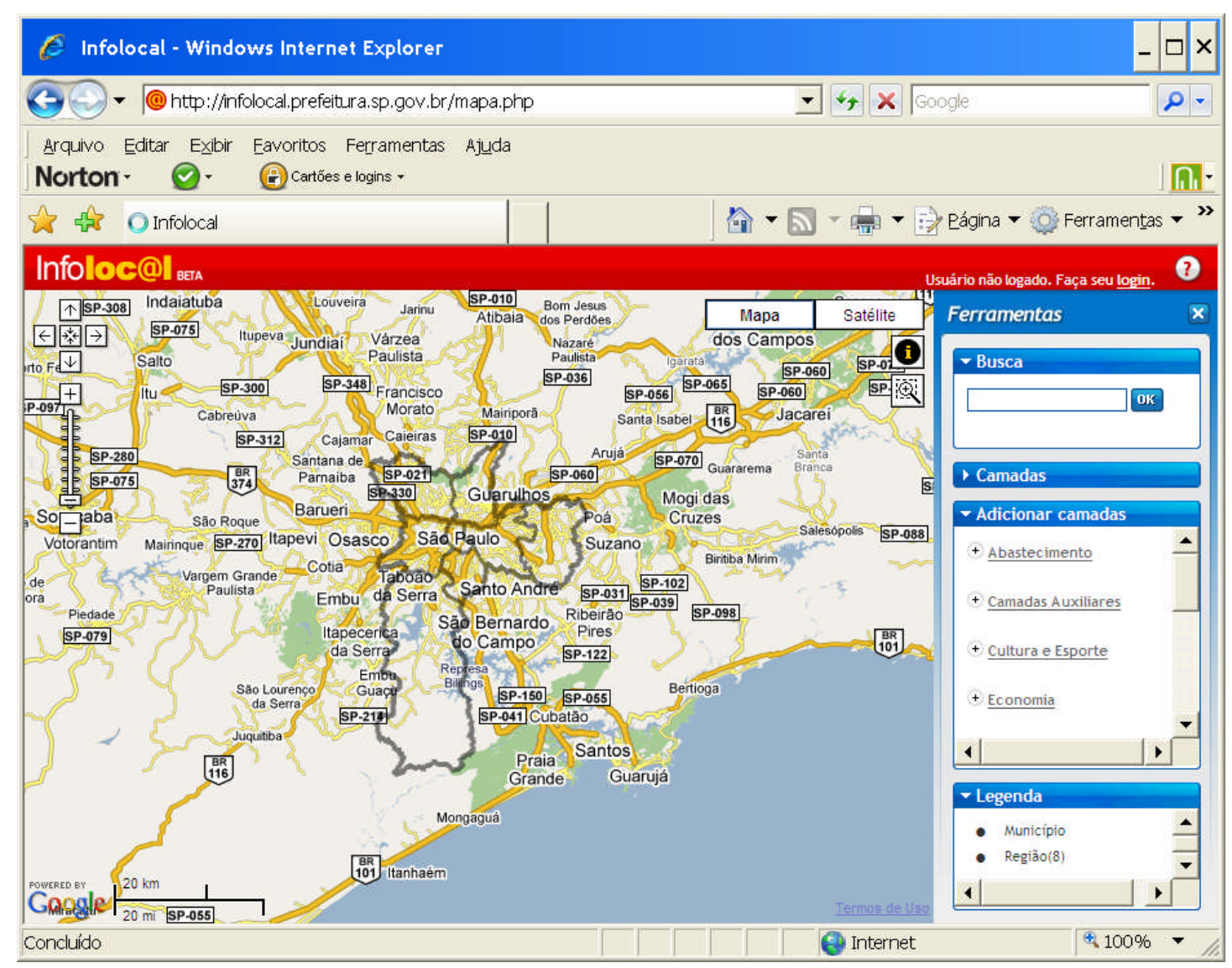

Figura 02 - Site da Prefeitura de São Paulo - Link para o Geoprocessamento

Em contrapartida, existem alguns trabalhos que merecem destaque, como o HABISP da Secretaria de Habitação - SEHAB. Os técnicos da SEHAB, com assistencia técnica da Aliança de Cidades (Cities Alliance), que é um consórcio internacional de cidades e organismos de desenvolvimento economico e social, em parceria desde 2003, mapearam e atualizaram os dados de assentamentos precários no município de São Paulo. Favelas, loteamentos irregulares e cortiços, encontam-se num software SIG, onde se definiu um modelo de priorização de atendimento através de parametros de avaliação destes assentamentos, propiciando um planejamento estratégico e de longo prazo. Fonte: Prefeitura do Município de São Paulo, Secretaria da Habitação , Sistema de Informação, disponível em www.habisp.sp.gov.br, acesso em 04 de jul. de 2009 


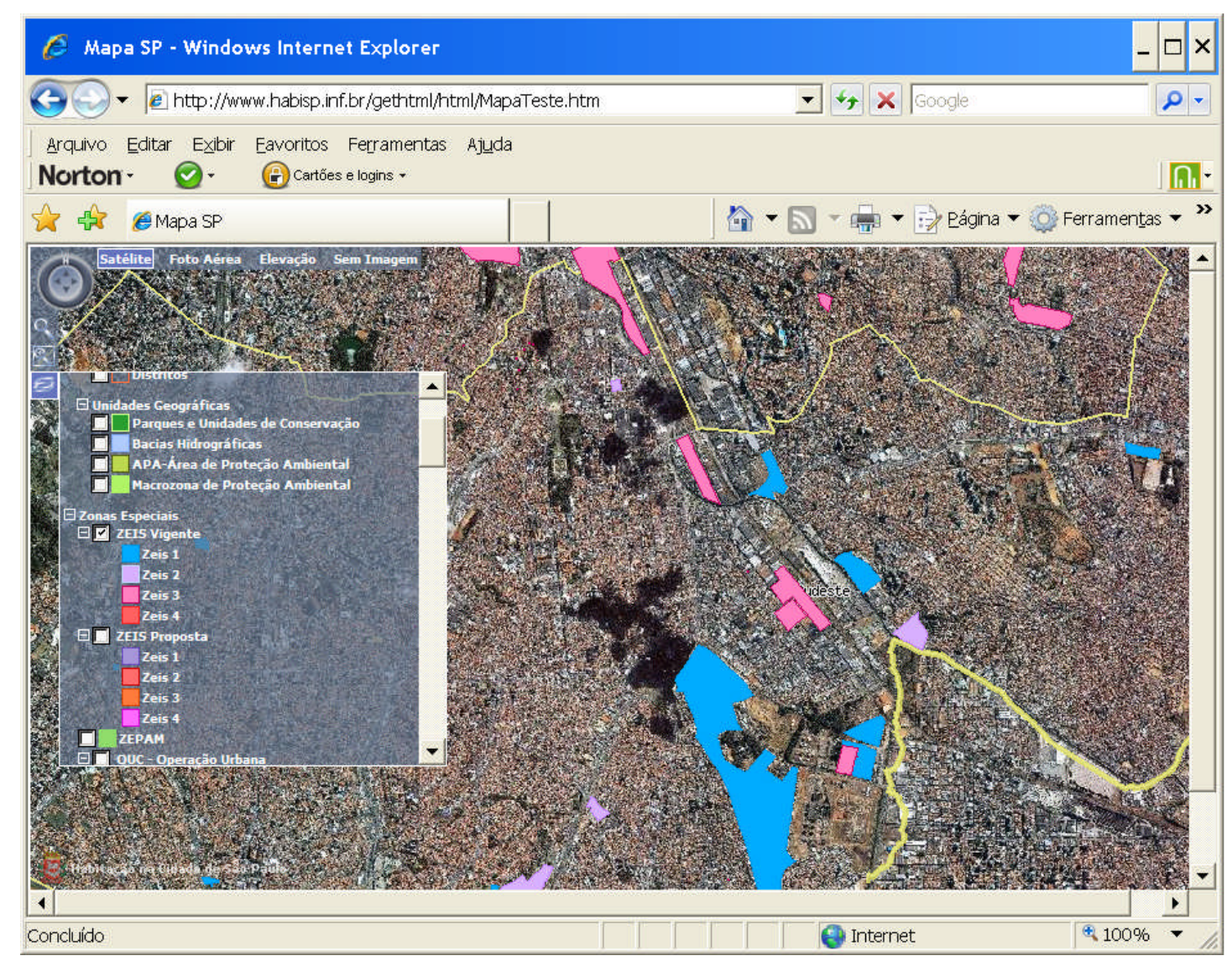

Figura 03 - Site da Prefeitura de São Paulo - SIG da Secretaria da Habitação - HABISP

$\mathrm{Na}$ análise de outras cidades da região sudeste, percebe-se que em geral começaram mais tarde que as capitais estaduais, porém alcançaram sucesso nos projetos. Um dos pontos a serem destacados pode ser o tamanho do município, que sendo menor, favorece um diálogo maior entre os envolvidos. No caso de Santo André, de acordo com a entrevista, houve uma grande cooperação dos funcionários que, vendo suas rotinas serem simplificadas, incorporaram o projeto e são os responsáveis pela atualização diária e on-line dos bancos de dados. Há uma preocupação em prestar o serviço público com informações atuais. Neste caso, Santo André usou a internet como a grande aliada para integrar toda a prefeitura.

As cidades maiores como São Paulo, BH e RJ passaram por diversas gestões com pouco ou nenhum apoio político. Todas têm processos longos internos que só recentemente se tornaram disponíveis à população através dos sites.

Belo Horizonte ainda não disponibilizou o SIG em Internet, mas existe um processo consolidado em ambiente intranet. A prefeitura conta com a empresa municipal Prodabel para gerenciamento de todas as bases, que também é um fator importante para grandes cidades, ter uma empresa de tecnologia de informação e 
comunicação para dar suporte aos trabalhos. Pontos críticos de $\mathrm{BH}$ : a falta de conscientização dos funcionários para incorporarem o SIG em suas rotinas.

O Rio de Janeiro, através do Instituto de Urbanização Pereira Passos torna público de forma organizada os mapas e dados do município. A existência de um portal Geo, dá mais legitimidade ao processo. A população acessa as informações de forma mais fácil do que nas outras capitais.

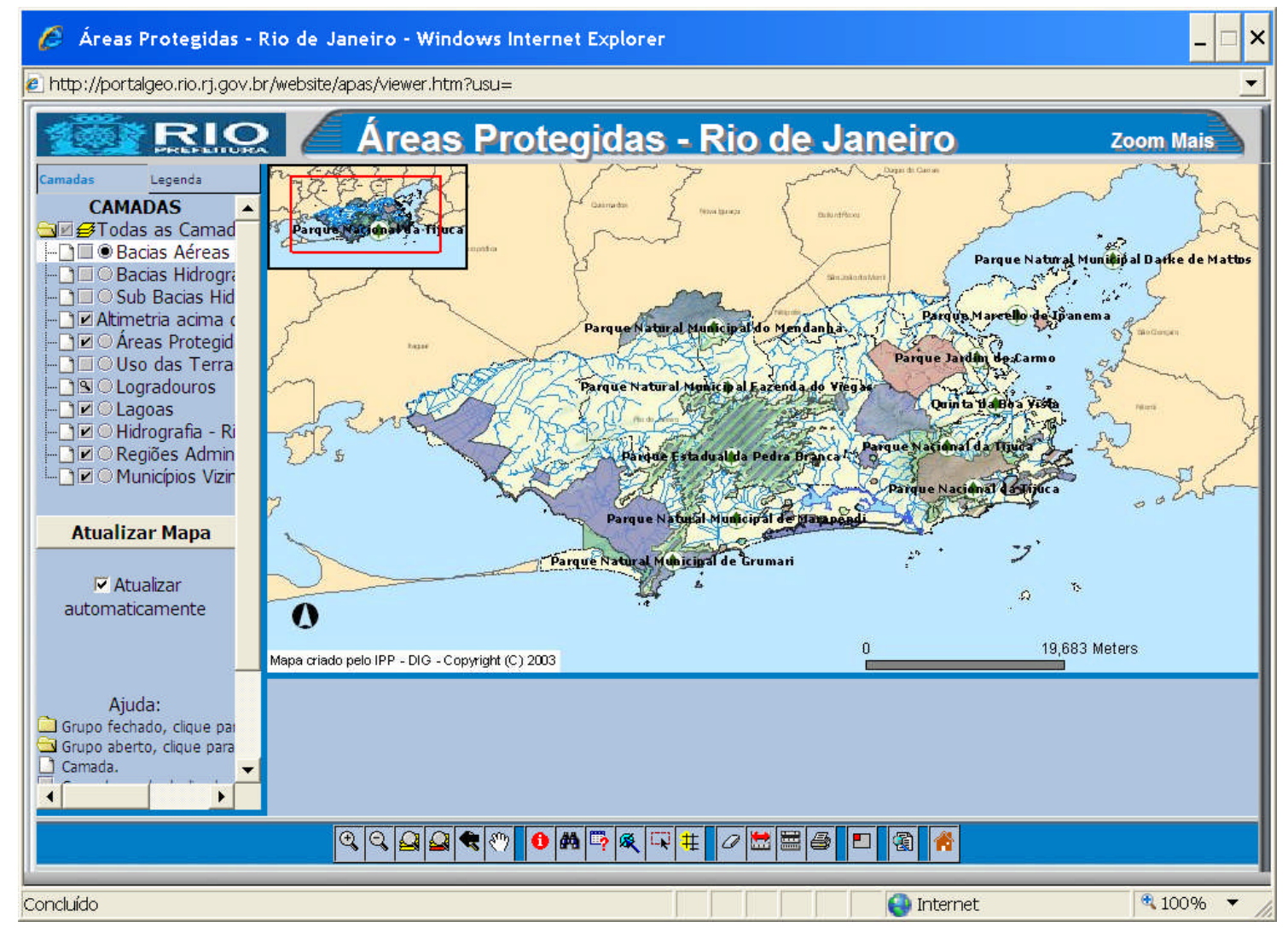

Fig. 04 - Portal Geo da Cidade do Rio de Janeiro

Pela entrevista com o município de Vitória, pode-se notar que percorreram um caminho individual no Estado. O Espírito Santo conta com um sistema Integrado de Bases Georreferenciadas denominado Geobases, implantado desde 1999 e que através de convênios fornece o sistema aos municípios e órgãos. Vitória contratou em 2007 uma restituição aerofotogramétrica em escala 1:1000 e acessa o Geobases quando precisa de informações na Região Metropolitana.

No geral, como não há um direcionamento de um órgão superior regulador, com uma política de desenvolvimento, os municípios sofrem com a dificuldade técnica de conhecimento. Existe uma duplicidade de esforços na composição do banco de dados alfanumérico e gastos excessivos com contratações de voos aerofotogramétricos que poderiam ser compartilhados numa iniciativa de Estados ou Regiões. 
Aparentemente essa fase de dificuldades iniciais, que passaram os municípios que se aventuraram na década de 90 vem diminuindo com a disseminação da tecnologia do SIG. Um município, hoje, que dá início na implantação do geoprocessamento, não precisa mais começar do "zero". Santos, por exemplo, passou um tempo estudando os melhores softwares, práticas e tecnologias antes de se aventurar no desenvolvimento dos trabalhos.

Outro fator presente no projeto do SIG de Santos foi o forte empenho do prefeito para dar condições à equipe gerenciadora do geoprocessamento. A administração contornou os problemas de falta de pessoal com a contratação de estagiários de universidade para concluírem a atualização do BD. Tiveram etapas bem elaboradas e com metas cumpridas.

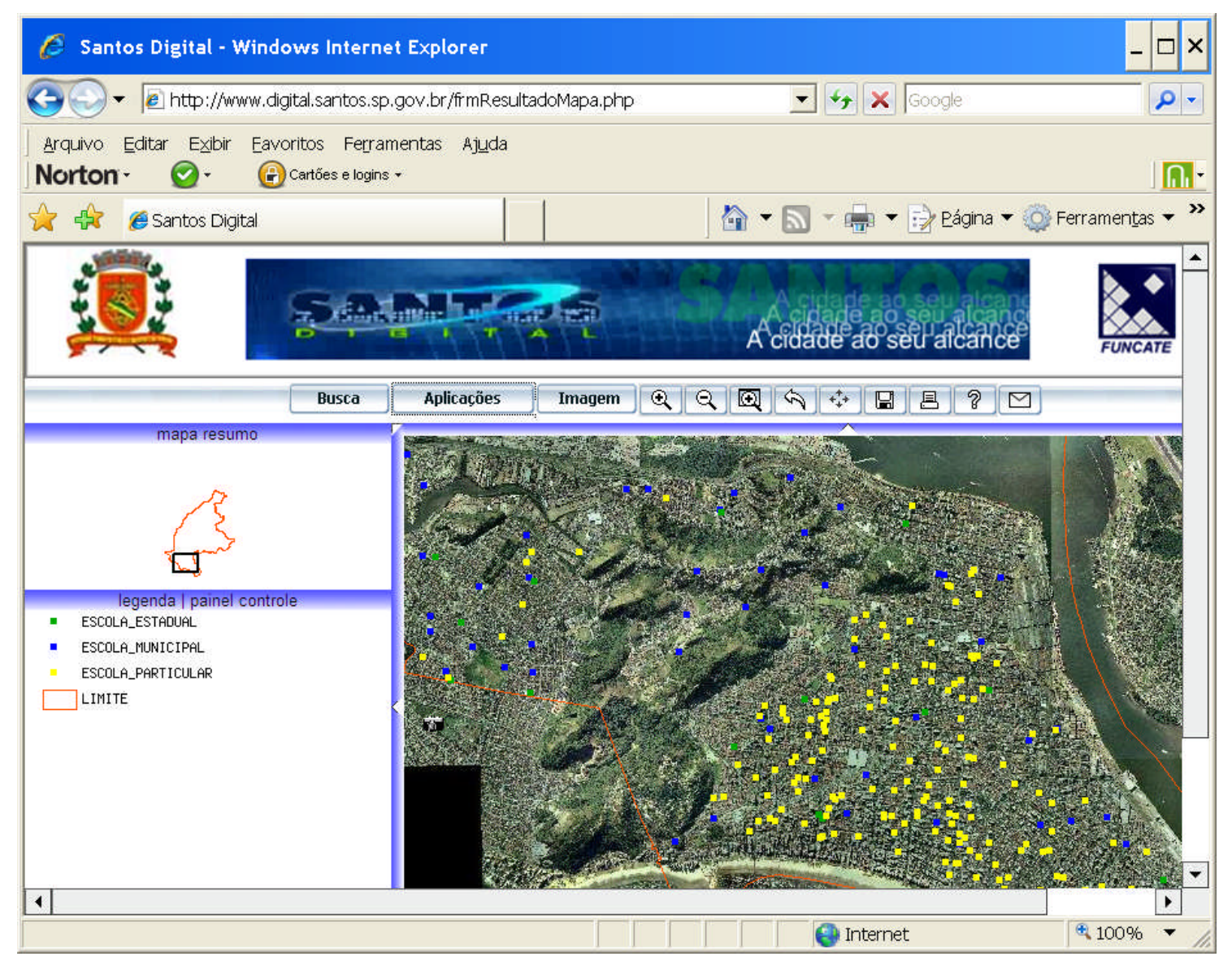

Fig. 05 - Site da Prefeitura de Santos - SIG Santos 
Região Centro Oeste - Capitais Estaduais

\begin{tabular}{|c|c|c|c|c|}
\hline $\begin{array}{l}\text { Questões } \\
n^{\circ} \text {. }\end{array}$ & $\begin{array}{l}\text { Municípios } \\
\text { Itens }\end{array}$ & Goiania & Cuiabá & $\begin{array}{l}\text { Campo } \\
\text { Grande }\end{array}$ \\
\hline 1 & $\begin{array}{l}\text { Tempo de } \\
\text { desenvolvimento }\end{array}$ & $\begin{array}{l}\text { Início em 1996, } \\
\text { mas Sistemas em } \\
\text { uso há } 11 \text { anos }\end{array}$ & $\begin{array}{l}\text { Início em } 2006 \\
\text { implantado desde } \\
2008\end{array}$ & $\begin{array}{l}\text { Não houve } \\
\text { resposta }\end{array}$ \\
\hline 2 & $\begin{array}{l}\text { Integração entre } 0 \\
\text { governo }\end{array}$ & $\begin{array}{ll}\text { Todas } & \text { as } \\
\text { secretarias } & \end{array}$ & $\begin{array}{l}\text { Inicio na S. das } \\
\text { Finanças }\end{array}$ & \\
\hline 3 & $\begin{array}{l}\text { Conhecimento da } \\
\text { tecnologia de SIG }\end{array}$ & $\begin{array}{l}\text { Pouca } \\
\text { consultoria externa }\end{array}$ & Consultoria externa & \\
\hline \multirow[t]{6}{*}{4} & $\begin{array}{l}\text { Apoio } \\
\text { político }\end{array}$ & Sim & SIm & \\
\hline & $\begin{array}{l}\text { Qualidade técnica e } \\
\text { gerencial }\end{array}$ & Sim & & \\
\hline & $\begin{array}{l}\text { Base de dados } \\
\text { alfanumérica }\end{array}$ & Sim & --- & \\
\hline & $\begin{array}{l}\text { Base de dados } \\
\text { cartográfica }\end{array}$ & $\begin{array}{l}\text { Sim, atualizada } \\
\text { constantemente }\end{array}$ & & \\
\hline & Software & $\begin{array}{l}\text { ArcView } 3 . x \text { e } \\
\text { ArcGIS 9.x }\end{array}$ & & \\
\hline & Hardware & Sem comentário & & \\
\hline 5 e 6 & $\begin{array}{l}\text { Resultados obtidos } \\
\text { com relação ao } \\
\text { objetivo do SIG }\end{array}$ & $\begin{array}{l}\text { Sim, diversas } \\
\text { análises espaciais }\end{array}$ & & \\
\hline 7 & Divulgação & $\begin{array}{l}\text { Sim } \\
\text { canais }\end{array}$ & & \\
\hline 8 & $\begin{array}{l}\text { Usabilidade e } \\
\text { facilidade de acesso }\end{array}$ & $\begin{array}{lr}\text { SIGGO só na } \\
\text { Intranet desde } 2008 \\
\text { com rários } \\
\text { aplicativos }\end{array}$ & & \\
\hline 9 & $\begin{array}{lr}\text { Evolução } & \text { e } \\
\text { seqüência } & \text { do } \\
\text { trabalho } & \end{array}$ & $\begin{array}{lr}\text { Evoluir } & \text { a } \\
\text { apresentação para } \\
\text { a Internet e } \\
\text { inclusão contínua } \\
\text { de aplicativos }\end{array}$ & & \\
\hline 10 & $\begin{array}{lr}\text { Democratização } & \text { do } \\
\text { acesso } & \text { e } \\
\text { oportunidade } & \text { de } \\
\text { participação } & \end{array}$ & $\begin{array}{l}\text { Pouca participação, } \\
\text { mas facilidade de } \\
\text { acesso }\end{array}$ & & \\
\hline 11 & $\begin{array}{l}\text { Usuário final: } \quad \text { o } \\
\text { cidadão }\end{array}$ & $\begin{array}{l}\text { Mais agilidade de } \\
\text { serviços e } \\
\text { planejamento com } \\
\text { melhor qualidade }\end{array}$ & & \\
\hline 12 & $\begin{array}{l}\text { Preparação para a } \\
\text { INDE }\end{array}$ & Não há & & \\
\hline
\end{tabular}

Quadro 38 - Itens para Avaliação de Projetos de SIGs Municipais da Região Centro Oeste Capitais Estaduais

Após a entrevista em Goiânia percebeu-se que houve um empenho diferenciado que resultou no sucesso da experiência. Primeiro em 1994, foi firmado um convênio para a construção do Mapa Urbano Básico Digital de Goiânia - MUBDG entre o município e as empresas de energia elétrica, saneamento e telefonia, respectivamente Celg, Saneago e Telegoiás. Em 1996, foi publicada a $1^{\text {a }}$ versão do mapa e já em 1997 houve a criação dos primeiros aplicativos SIG. Em 1999, foi 
publicado o SIGGO, visualizador de mapas digitais, e distribuídas milhares de cópias à população. Nota-se, então, que houve um apoio interinstitucional para centralizar esforços que resultou numa base digital confiável que há dez anos é disponibilizada à população. O MUBDG, foi mantido por uma equipe própria da prefeitura responsável pelas atualizações. Esse processo contínuo de alimentação e atualização, propiciou o uso de diversas análises espaciais de forma crescente, culminando na implantação do SIGGO na intranet com diversos aplicativos em 2008. A população tem acesso aos produtos, mas por canais de atendimento, sem o aplicativo disponível na internet.

Apesar de Goiânia ter um processo de implantação de SIG consolidado, o técnico responsável pelo geoprocessamento, Flávio Yuasa, acredita que ainda não atingiram 0 ideal, pois enfrentam dificuldades advindas da complexidade organizacional da cidade com mais de 1 milhão de habitantes.

Cuiabá não respondeu ao questionário, mas notícias no site da prefeitura informam que o projeto de implantação do geoprocessamento no município começou a ser implantado no início de 2006 e após 23 meses de trabalho, foi entregue pela empresa de consultoria que executou em conjunto com a prefeitura em 2008. O SIG foi desenvolvido principalmente para a Secretaria de Finanças, visando o aumento da arrecadação. Cuiabá saltou nos últimos 50 anos de 57 mil habitantes para cerca de 700 mil. A administração da cidade não acompanhou o crescimento desordenado da área urbana e a capital não tinha um cadastro mobiliário organizado. O Secretário das Finanças diz que o aumento da arrecadação será de $10 \%$. Ao todo, o projeto do geoprocessamento custou mais de $\mathrm{R} \$ 4,5$ milhões e foi financiado pelo PNAFM Programa Nacional de Apoio a Gestão Administrativa e Fiscal dos Municípios, criado pelo governo federal. Ele possibilita que gestores municipais possam otimizar o processo de gestão e organizar a arrecadação tributária. Participam do programa os municípios, o Banco Interamericano de Desenvolvimento (BID), a União, o Ministério da Fazenda (por meio da Unidade de Coordenação de Programas - UCP) e a Caixa Econômica Federal.

O programa PNAFM contempla itens que visam modernizar a gestão administrativa e fiscal do município através de ações como a capacitação de técnicos e gestores municipais, implementação de ações e sistemas destinados ao controle da arrecadação, atendimento ao cidadão, comunicação de dados, controle financeiro, recursos humanos, consultorias, aquisição de equipamentos de informática, infraestrutura e geoprocessamento. Além de Cuiabá, inúmeros outros municípios vëm usando os recursos do Programa para implantação do Geoprocessamento e ou modernização administrativa. São eles: Salvador, São Bernardo do Campo, Diadema, 
Juiz de Fora, Itu, Blumenau, Campo Grande, Joinville, Recife, Fortaleza, Goiânia, Natal, Jacareí, Recife, Aracaju, Maceió, São Luis, entre outros.

"A abertura do VII Encontro de Coordenação do PNAFM em maio de 2007, autoridades presentes ressaltaram o caráter estratégico, democrático e fundamental do PNAFM para a sociedade brasileira. Claudia Brandão, superintendente nacional de Desenvolvimento Social da Caixa Econômica Federal, entidade co-gestora do Programa afirmou que o PNAFM pode fazer a diferença no desempenho da gestão pública, sustentando que são os municípios que fazem acontecer o desenvolvimento do País (...) $A$ representante do Banco Interamericano de Desenvolvimento (BID), Maria de Fátima Cartaxo, seguiu o mesmo raciocínio e elogiou o processo de implantação do PNAFM. Segundo ela, o PNAFM é, atualmente, o programa de modernização conduzido com recursos do BID mais bem estruturado em vigência no país. Ela lançou um desafio para as prefeituras e órgãos envolvidos com o PNAFM, para que transformem o Programa no grande carro-chefe da modernização do Estado brasileiro. Segundo Fátima Cartaxo, o PNAFM tem as melhores condições de influir no desenvolvimento municipal."

Fonte: UCP - Unidade de Coordenação do Programa, Relatório do VII Encontro. Disponível em www.ucp.fazenda.gov.br/PNAFM/relatorios. Acesso em 18/06/2009.

Campo Grande também não enviou o questionário, mas novamente com informações na Internet, pode-se saber que o geoprocessamento surgiu visando o aprimoramento da administração. Em fevereiro de 2006, foi criado o Sistema Municipal de Geoprocessamento (Simgeo), passando a existir a necessidade de uma base cartográfica cadastral atualizada. Com a conclusão dos trabalhos de ortofoto digital, o Município pode utilizar as informações para as áreas: planejamento urbano, planejamento e gestão da malha viária, planejamento e gestão de redes de drenagem, mapeamento das áreas de risco ambiental.

A equipe técnica da Secretaria Municipal de Meio Ambiente e
Desenvolvimento Urbano (Semadur) apresentou, em 10/03/2009, para o
prefeito, as atualizações do Programa de Georreferência de Campo Grande. 
Dentro do programa de mapeamento está o Geomorena, que compreende um conjunto de informações geográficas sobre a cidade, elaboradas com base na moderna técnica aerofotogramétrica. Até o ano passado, todas as informações sobre a área rural do município eram apresentadas de forma analógica. A partir do último vôo, aerofotogramétrico, todas as informações sobre o mapeamento da área urbana $\left(360 \mathrm{~km}^{2}\right)$ e área rural $\left(8.118,4 \mathrm{~km}^{2}\right)$ do município foram totalmente digitalizadas." Disponível em http.:/www.pmcg.ms.gov.br, publicado em 12/03/2009 pela CGNotícias e acesso em 20/06/2009.

Região Norte - Capitais Estaduais

\begin{tabular}{|c|c|c|c|c|}
\hline $\begin{array}{l}\text { Questões } \\
n^{\circ} \text {. }\end{array}$ & $\begin{array}{l}\text { Municípios } \\
\text { Itens }\end{array}$ & Palmas & Manaus & Belém \\
\hline 1 & $\begin{array}{ll}\text { Tempo } & \text { de } \\
\text { desenvolvimento }\end{array}$ & & $\begin{array}{l}\text { Início em } 1999 \\
\text { 10anos }\end{array}$ & Início em 2009 \\
\hline 2 & $\begin{array}{l}\text { Integração entre o } \\
\text { governo }\end{array}$ & & $\begin{array}{l}\text { Poucas } \\
\text { secretarias }\end{array}$ & Sem informação \\
\hline 3 & $\begin{array}{l}\text { Conhecimento da } \\
\text { tecnologia de SIG }\end{array}$ & & s/ informação & $\begin{array}{l}\text { Contratação de } \\
\text { consultoria }\end{array}$ \\
\hline \multirow[t]{6}{*}{4} & $\begin{array}{l}\text { Apoio } \\
\text { político }\end{array}$ & & & s/ informação \\
\hline & $\begin{array}{l}\text { Qualidade técnica e } \\
\text { gerencial }\end{array}$ & & Sim & $\begin{array}{l}\text { A consultoria irá } \\
\text { trabalhar c/ } \\
\text { técnicos da } \\
\text { Cinbesa }\end{array}$ \\
\hline & $\begin{array}{l}\text { Base de dados } \\
\text { alfanumérica }\end{array}$ & & & Em levantamento \\
\hline & $\begin{array}{l}\text { Base de dados } \\
\text { Cartográfica }\end{array}$ & & & Em levantamento \\
\hline & Software & & & s/ informação \\
\hline & Hardware & & Sem comentário & s/ informação \\
\hline 5 e 6 & $\begin{array}{l}\text { Resultados obtidos } \\
\text { com relação ao } \\
\text { objetivo do SIG }\end{array}$ & & $\begin{array}{l}\text { Sim, diversas } \\
\text { análises } \\
\text { espaciais }\end{array}$ & $\begin{array}{l}\text { Ainda } \\
\text { resultados }\end{array}$ \\
\hline 7 & Divulgação & Sim & Não & Não \\
\hline 8 & $\begin{array}{l}\text { Usabilidade e } \\
\text { facilidade de acesso }\end{array}$ & $\begin{array}{l}\text { Portal SIG } \\
\text { Palmas }\end{array}$ & Só intranet & Não \\
\hline 9 & $\begin{array}{lr}\text { Evolução } & \text { e } \\
\text { seqüência } & \text { do } \\
\text { trabalho } & \end{array}$ & & & $\begin{array}{l}\text { Implantação } \\
\text { efetiva do SIG }\end{array}$ \\
\hline 10 & $\begin{array}{lr}\text { Democratização } & \text { do } \\
\text { acesso } & \text { e } \\
\text { oportunidade } & \text { de } \\
\text { participação } & \end{array}$ & Sim & & s/ informação \\
\hline 11 & $\begin{array}{l}\text { Usuário final: } \\
\text { cidadão }\end{array}$ & $\begin{array}{l}\text { Informação } \\
\text { disponível }\end{array}$ & $\begin{array}{l}\text { Informação } \\
\text { disponível }\end{array}$ & s/ informação \\
\hline 12 & $\begin{array}{l}\text { Preparação para a } \\
\text { INDE }\end{array}$ & & Não há & s/ informação \\
\hline
\end{tabular}

Quadro 39 - Itens para Avaliaçõa de Projetos de SIGs Municipais na Região Norte - Capitais Estaduais

Na Região Norte as cidades: Rio Branco (AC), Boa Vista (RR), Porto Velho (RO), Macapá (AP), não responderam ao questionário. 
Na região norte, poucos contatos foram conseguidos. Através de telefone, somente Manaus e Belém. Por email, todos, porém sem resposta. Na análise do sítio municipal de Palmas, existe um link discreto para o portal SIG Palmas, no endereço http.://www.palmas.to.gov.br/secretaria/habitação_index.asp que atualmente disponibiliza vários mapas temáticos do município para impressão em pdf, jpg ou imagens de arcgis, mas apenas como figuras estáticas sem interação com o usuário. O sistema não permite buscas nos mapas, nem que o usuário faça sua própria composição.

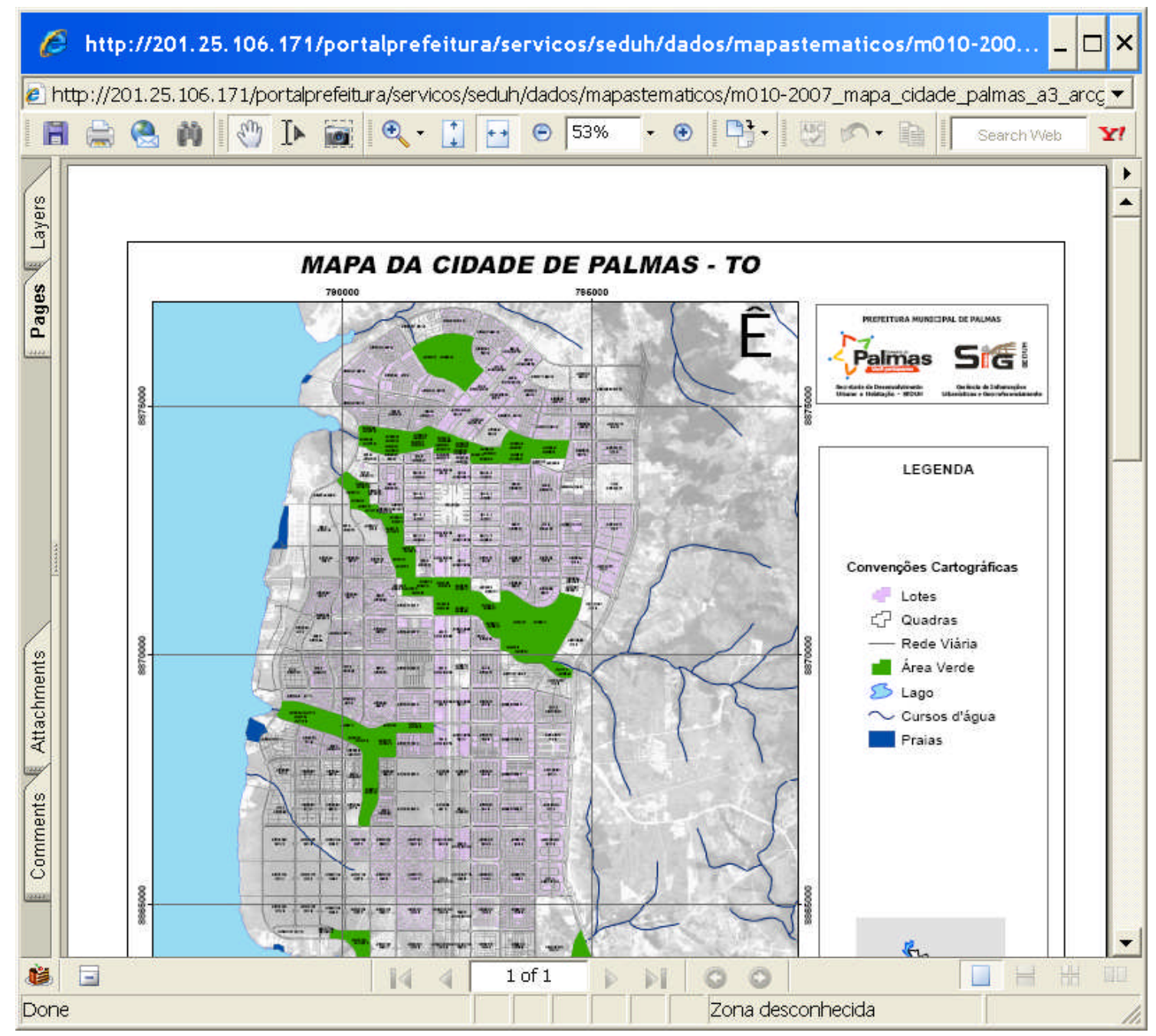

Fig. 06 - Site da Prefeitura de Palmas

Belém informou que está no início dos trabalhos, em análise do processo licitatório para contratação da empresa de consultoria.

Manaus tem um projeto de SIG implantado desde 1999 em uso principalmente pelas secretarias de planejamento, finanças, educação e informática. 
Ficou de enviar o questionário respondido com maiores detalhes, mas até o fechamento desta pesquisa não enviou.

Entre as outras capitais da região norte pesquisadas, somente foi obtido contato com Rio Branco, que está em um sério processo de reestruturação administrativa para melhorar a gestão, favorecendo a participação popular, presente em notícias no portal municipal, mas o responsável pelas informações não retornou o contato até o encerramento da pesquisa.

Região Nordeste - Capitais Estaduais

\begin{tabular}{|c|c|c|c|c|c|}
\hline $\begin{array}{l}\text { Questões } \\
n^{\circ} \text {. }\end{array}$ & $\begin{array}{l}\text { Municípios } \\
\text { Itens }\end{array}$ & Salvador & Aracaju & Maceió & Recife \\
\hline 1 & $\begin{array}{l}\text { Tempo de } \\
\text { desenvolvimento }\end{array}$ & $\begin{array}{l}\text { Inicio em } \\
1998-11 \\
\text { anos }\end{array}$ & $\begin{array}{l}\text { Início final } \\
\text { dos anos } 90 \\
\text { Efetivo } 2001 \\
8 \text { anos }\end{array}$ & $\begin{array}{l}\text { Sem } \\
\text { resposta }\end{array}$ & $\begin{array}{l}\text { Desde } 2005 \\
\text { Em uso desde } \\
2008\end{array}$ \\
\hline 2 & $\begin{array}{l}\text { Integração entre } \\
\text { o governo }\end{array}$ & $\begin{array}{l}\text { Poucas } \\
\text { secretarias }\end{array}$ & $\begin{array}{l}\text { Várias } \\
\text { secretarias }\end{array}$ & -- & Quase todas \\
\hline 3 & $\begin{array}{l}\text { Conhecimento } \\
\text { da tecnologia de } \\
\text { SIG }\end{array}$ & $\begin{array}{l}\text { Tiveram } \\
\text { consultoria } \\
\text { externa }\end{array}$ & $\begin{array}{l}\text { Tiveram } \\
\text { consultoria } \\
\text { externa }\end{array}$ & -- & $\begin{array}{l}\text { Equipe interna } \\
\text { de } \\
\text { desenvolvimento }\end{array}$ \\
\hline \multirow[t]{6}{*}{4} & $\begin{array}{l}\text { Apoio } \\
\text { político }\end{array}$ & Não há & Sim & -- & Sim \\
\hline & $\begin{array}{l}\text { Qualidade } \\
\text { técnica } \\
\text { gerencial }\end{array}$ & $\begin{array}{l}\text { Existe } \quad 0 \\
\text { Comitê de } \\
\text { Geo mas não } \\
\text { se reuniram }\end{array}$ & Sim & Sim & Sim \\
\hline & $\begin{array}{l}\text { Base de dados } \\
\text { alfanumérica }\end{array}$ & Sim & $\begin{array}{l}\text { Sim } \\
\text { atualizado }\end{array}$ & Sim & Sim \\
\hline & $\begin{array}{l}\text { Base de dados } \\
\text { cartográfica }\end{array}$ & $\begin{array}{l}\text { Sem } \\
\text { qualidade }\end{array}$ & Sim & Sim & Sim \\
\hline & Software & $\begin{array}{l}\text { Sem } \\
\text { comentário }\end{array}$ & $\begin{array}{l}\text { Sem } \\
\text { comentário }\end{array}$ & -- & $\begin{array}{l}\text { Arcgis -ESRI e } \\
\text { licensas Open } \\
\text { Gis * }\end{array}$ \\
\hline & Hardware & $\begin{array}{l}\text { Sem } \\
\text { comentário }\end{array}$ & $\begin{array}{l}\text { Sem } \\
\text { comentário }\end{array}$ & -- & $\begin{array}{l}\text { Sem } \\
\text { comentário }\end{array}$ \\
\hline 5 e 6 & $\begin{array}{l}\text { Resultados } \\
\text { obtidos com } \\
\text { relação ao } \\
\text { objetivo do SIG }\end{array}$ & $\begin{array}{l}\text { Vizualizações } \\
\text { em mapas } \\
\text { através do } \\
\text { Google maps }\end{array}$ & $\begin{array}{l}\text { Sim, diversas } \\
\text { análises } \\
\text { espaciais } \\
\text { inclusive } \\
\text { para o } \\
\text { P.Diretor }\end{array}$ & -- & $\begin{array}{l}\text { Integração das } \\
\text { secretarias, } \\
\text { agilizar } \\
\text { otimizar } \\
\text { decisões }\end{array}$ \\
\hline 7 & Divulgação & Não & Não & Não & Não \\
\hline 8 & $\begin{array}{l}\text { Usabilidade } \\
\text { facilidade } \\
\text { acesso }\end{array}$ & Não & Só intranet & $\begin{array}{l}\text { Só mapas } \\
\text { em PDF }\end{array}$ & \begin{tabular}{lr}
\multicolumn{2}{c}{ Será lançada a } \\
fase & de \\
interação & na \\
internet &
\end{tabular} \\
\hline 9 & $\begin{array}{l}\text { Evolução } \\
\text { seqüência } \\
\text { trabalho }\end{array}$ & $\begin{array}{l}\text { Dar } \\
\text { continuidade } \\
\text { aos trabalhos } \\
\text { iniciais }\end{array}$ & $\begin{array}{l}\text { Aguardando } \\
\text { melhora do } \\
\text { link externo } \\
\text { da Prefeitura } \\
\text { p/ sua } \\
\text { operação na } \\
\text { internet }\end{array}$ & $\begin{array}{l}\text { Sem } \\
\text { resposta }\end{array}$ & $\begin{array}{l}\text { Em agosto/09 } \\
\text { devem lançar } \\
\text { um aplicativo } \\
\text { na internet }\end{array}$ \\
\hline 10 & $\begin{array}{l}\text { Democratização } \\
\text { do acesso e } \\
\text { oportunidade de }\end{array}$ & Não & $\begin{array}{l}\text { Não por } \\
\text { enquanto }\end{array}$ & $\begin{array}{l}\text { Sim } \\
\text { audiências } \\
\text { públicas }\end{array}$ & $\begin{array}{l}\text { Não, somente } \\
\text { previsão }\end{array}$ \\
\hline
\end{tabular}




\begin{tabular}{|l|l|l|l|l|l|}
\hline 11 & $\begin{array}{l}\text { participação } \\
\text { Usuário final: o } \\
\text { cidadão }\end{array}$ & $\begin{array}{l}\text { Informac̃ão } \\
\text { disponível }\end{array}$ & $\begin{array}{l}\text { Informacão } \\
\text { disponível }\end{array}$ & $\begin{array}{l}\text { Informação } \\
\text { disponível }\end{array}$ & $\begin{array}{l}\text { As } \\
\text { intervenções } \\
\text { são analisadas } \\
\text { com } \begin{array}{c}\text { mais } \\
\text { senso social. }\end{array}\end{array}$ \\
\hline 12 & $\begin{array}{l}\text { Preparação para } \\
\text { a INDE }\end{array}$ & Não há & Não há & s/ resposta & Não há \\
\hline
\end{tabular}

Quadro 40 - Itens para Avaliação dos Projetos de SIGs Municipais na Região Nordeste Capitais Etaduais - parte 1

As capitais estaduais da região nordeste também passaram pelos desencontros da década de 90 e em algumas ainda persistem os erros. Salvador teve uma contratação de consultoria externa que não evoluiu e recentemente foi criado o Comitê de Geoprocessamento na Congel - Cia de Governança Eletrônica em Salvador, mas ainda não definiram ações efetivas. Existiu um voo aerofotogramétrico em 2006 mas seus produtos não são usados pela prefeitura toda. A entrevista identificou que falta direcionamento para os trabalhos e falta uma disseminação da cultura da tecnologia entre os funcionários, que apoiam algumas tarefas e produtos no Google Maps.

A prefeitura de Aracaju ilustra bem o que aconteceu com vários municípios: no final da década de 90 , quatro funcionários ficaram à frente de uma tentativa de implantação, participaram de seminários, contrataram uma empresa de geoprocessamento que não previa a transferência da tecnologia e obrigava o município a renovar licenças periodicamente para poder continuar usando o sistema.

Dentre os principais equívocos apontados na entrevista "foi a tentativa de uso da tecnologia sem ter sido criado antes uma cultura geográfica e um convencimento pleno das autoridades e servidores sobre as vantagens que o GEO poderia trazer à gestão urbana”. Segundo o Diretor de Gestão Urbana da Secretaria de Planejamento, Juan Carlos Gortaire Cordovez, "O município também não contava com dados e informações georreferenciadas suficientes para alimentar o sistema, nem usuários convencidos e preparados para utilizá-los". 


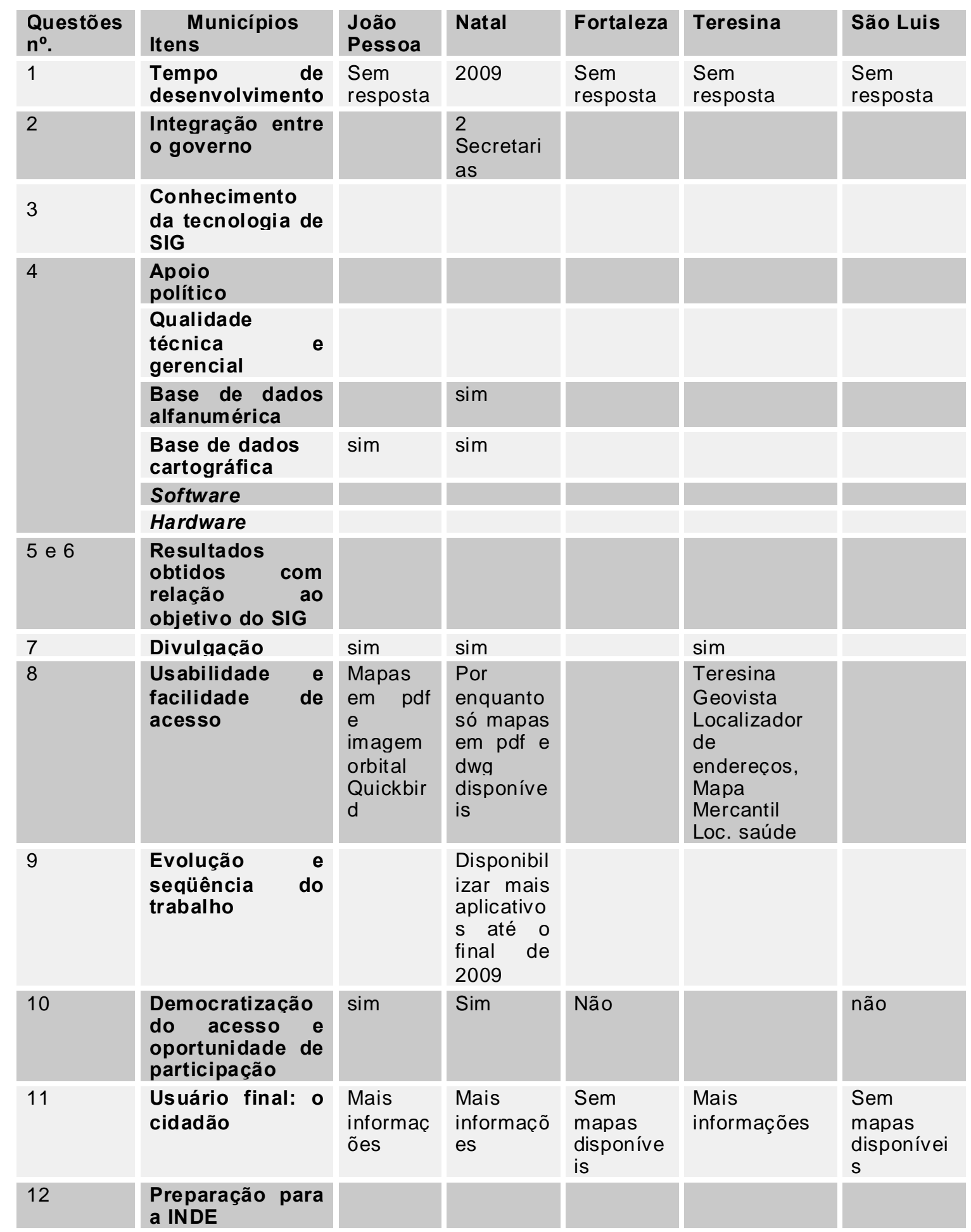

Quadro 41 - Itens para Avaliação dos Projetos de SIGs Municipais na Região Nordeste Capitais Estaduais - parte 2

A região nordeste ficou com a análise prejudicada pela ausência de informações em diversas cidades. Tentando contato através de telefonema, através do link "fale conosco", e-mail para as secretarias de planejamento, além de pesquisa sobre notícias de geoprocessamento na cidade, mas todas as tentativas sem sucesso. 
Em algumas cidades, acessamos mapas em PDF com a divisão por bairros, contendo logradouros, equipamentos públicos como em Maceió e João Pessoa. Ambas as cidades possuem uma Diretoria de Geoprocessamento subordinada à Secretaria Municipal de Planejamento. João Pessoa, além dos mapas em PDF, também disponibiliza no site imagens de satélite Quickbird. Conforme quadro abaixo:

\section{Arquivos Disponibilizados}

A Prefeitura Municipal de João Pessoa está disponibilizando Cartas Imagem Quickbird de Outubro de 2005, em formato de papel A3, separados por Bairros. Estes arquivos disponíveis para download apresentam as seguintes camadas de informação: Limite de Bairro; Eixo de Vias; Nome de Logradouros.

O Sistema Cartográfico adotado é o mesmo adotado para os Marcos Geodésicos da cidade de João Pessoa. Observe os tamanhos dos arquivos, que podem levar alguns minutos para carregar. (Formato PDF)

Quadro 42 - Site da Prefeitura de João Pessoa

Em Natal, o projeto de implantação do SIG é bem recente, maio de 2009, o departamento de Geoprocessamento está testando os aplicativos no software que por enquanto estão disponíveis apenas para duas secretarias, a de Meio Ambiente e Urbanismo e a de Tributação. Embora o SIG esteja no começo, há trabalhos de geoprocessamento no município, pois é possível acessar mapas produzidos na página inicial do portal municipal. Existem os mapas com o Plano Diretor em pdf, arruamentos do municípo todo em Autocad e diversos mapas temáticos em pdf, com localizações sobre imagem de satélite.

De acordo com Reginaldo Vasconcelos, chefe do Departamento de
Geoprocessamento da SEMURB de Natal, o SIG deverá estar em pleno
funcionamento até o final do ano. "É um programa que exige muito cuidado, já que as
informações que ele disponibilizará, serão base de futuras ações e projetos da
secretaria, por isso é importante o tempo para aperfeiçoá-lo", explica.
Reginaldo explica ainda que o sistema vai mudar a forma como as decisões
são tomadas. "Com esse programa, as secretárias serão amparadas por informações
mais precisas. É um salto administrativo inimaginável", conclui. - fonte Notícias em
www.natal.rn.gov.br/ acesso em 24/06/2009.

Quadro 43 - Site da Prefeitura de Natal 


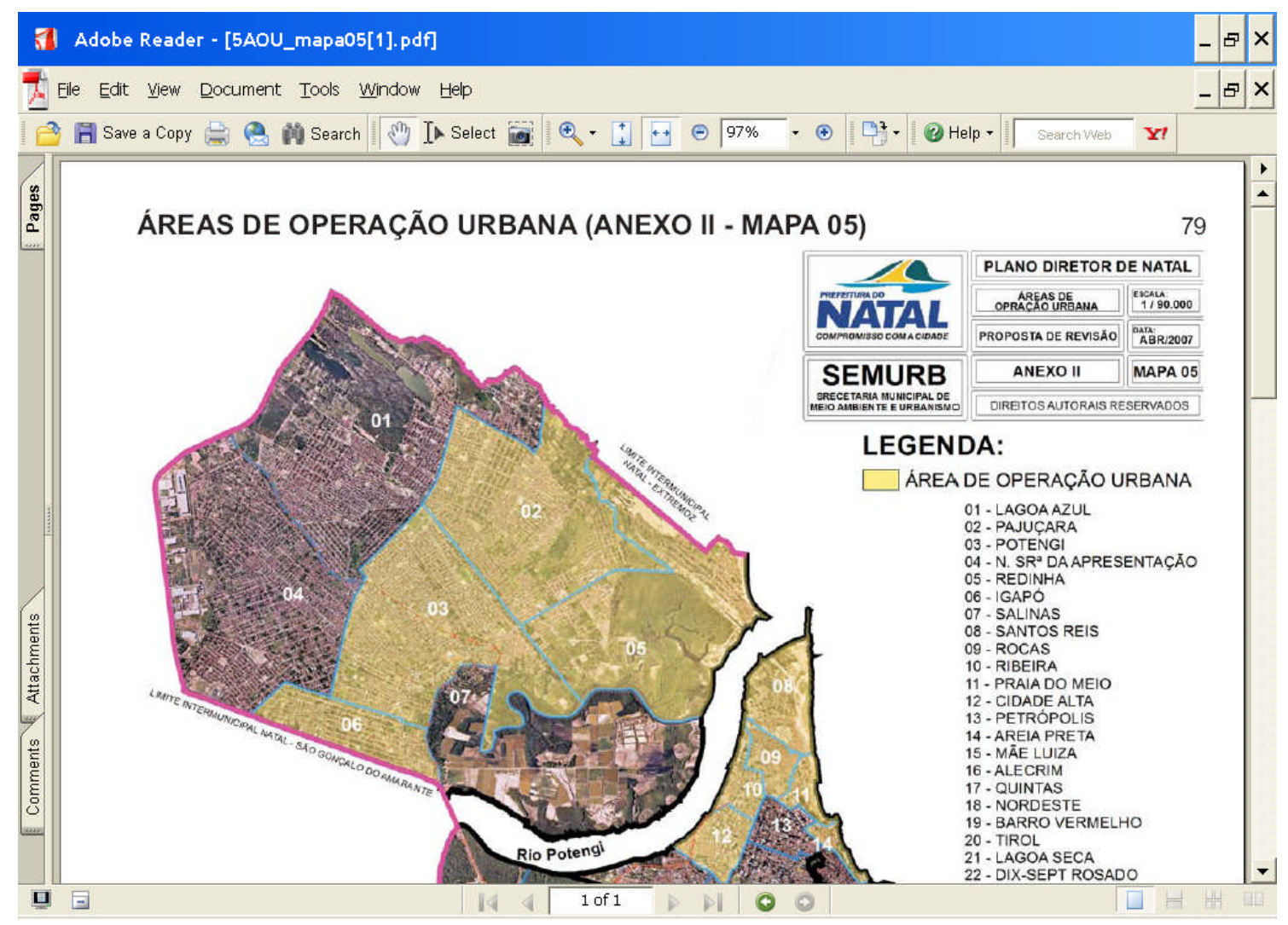

Figura 07 - Site da Prefeitura de Natal - Mapas disponíveis em PDF

Teresina tem um portal de geoprocessamento que pode ser acessado através do site da prefeitura. O projeto tem o nome de Teresina Geovista, é desenvolvido pela Prodater - Processamento de Dados de Teresina e disponibiliza localizador de endereços, rede de referência cadastral, mapa mercantil, localidades de saúde. Também existem mapas em PDF e tabelas de informações sobre os bairros em PDF na Secretaria de Planejamento.

A Prefeitura de São Luis em seu site não disponibiliza mapas, não tem mecanismo de busca e nem o telefone da administração. Existe uma mensagem que um novo portal está em desenvolvimento. Tentamos acesso através de telefone e através do Governo Estadual, mas sem resposta.

A Prefeitura de Fortaleza também não disponibiliza mapas no portal municipal e a Secretaria de Planejamento estava em mudança de prédio sem telefone ou email disponíveis. 
Região Sul - Capitais Estaduais

\begin{tabular}{|c|c|c|c|c|}
\hline $\begin{array}{l}\text { Questões } \\
n^{\circ} \text {. }\end{array}$ & $\begin{array}{l}\text { Municípios } \\
\text { Itens }\end{array}$ & Curitiba & Florianópolis & Porto Alegre \\
\hline 1 & $\begin{array}{l}\text { Tempo de } \\
\text { desenvolvimento }\end{array}$ & Desde 1984 & $\begin{array}{l}\text { Inicio em } 2003 \\
6 \text { anos }\end{array}$ & Inicio em 2000 \\
\hline 2 & $\begin{array}{l}\text { Integração entre } \\
\text { o governo }\end{array}$ & $\begin{array}{l}\text { Todas as } \\
\text { secretarias }\end{array}$ & $\begin{array}{l}\text { Todas as } \\
\text { secretarias }\end{array}$ & $\begin{array}{l}\text { Todas as } \\
\text { secretarias }\end{array}$ \\
\hline 3 & $\begin{array}{l}\text { Conhecimento } \\
\text { da tecnologia de } \\
\text { SIG }\end{array}$ & Sim & Não informado & $\begin{array}{l}\text { Equipe interna } \\
\text { de } \\
\text { desenvolvimento }\end{array}$ \\
\hline \multirow[t]{6}{*}{4} & $\begin{array}{l}\text { Apoio } \\
\text { político }\end{array}$ & $\begin{array}{l}\text { Já esteve } \\
\text { melhor }\end{array}$ & Sim & Sim \\
\hline & $\begin{array}{l}\text { Qualidade } \\
\text { técnica } \\
\text { gerencial }\end{array}$ & $\operatorname{sim}$ & Sim & Sim \\
\hline & $\begin{array}{l}\text { Base de dados } \\
\text { alfanumérica }\end{array}$ & Sim & Sim & Sim \\
\hline & $\begin{array}{l}\text { Base de dados } \\
\text { cartográfica }\end{array}$ & $\begin{array}{l}\text { Precisa } \\
\text { atualizar }\end{array}$ & Sim & Sim \\
\hline & Software & Não inf. & Não informado & Não informado \\
\hline & Hardware & $\begin{array}{l}\text { Sem } \\
\text { comentário }\end{array}$ & $\begin{array}{l}\text { Sem } \\
\text { comentário }\end{array}$ & $\begin{array}{l}\text { Sem } \\
\text { comentário }\end{array}$ \\
\hline 5 e 6 & $\begin{array}{lr}\text { Resultados } & \\
\text { obtidos } & \text { com } \\
\text { relação } & \text { ao } \\
\text { objetivo do SIG }\end{array}$ & $\begin{array}{l}\text { Sim, diversas } \\
\text { análises } \\
\text { espaciais }\end{array}$ & $\begin{array}{l}\text { Sim, diversas } \\
\text { análises } \\
\text { espaciais }\end{array}$ & $\begin{array}{l}\text { Sim, diversas } \\
\text { análises } \\
\text { espaciais }\end{array}$ \\
\hline 7 & Divulgação & pouca & Sim & não \\
\hline 8 & $\begin{array}{l}\text { Usabilidade } \\
\text { facilidade } \\
\text { acesso }\end{array}$ & $\begin{array}{l}\text { Não existe } \\
\text { portal de geo }\end{array}$ & $\begin{array}{lr}\text { Sim } & \text { existência } \\
\text { de } & \text { portal } \\
\text { único, } & \text { com } \\
\text { várias } & \\
\text { ferramentas }\end{array}$ & $\begin{array}{l}\text { No site da } \\
\text { prefeitura tem } \\
\text { um link para } \\
\text { mapas de P.A. } \\
\text { com algumas } \\
\text { informações }\end{array}$ \\
\hline 9 & $\begin{array}{lr}\text { Evolução } & \text { e } \\
\text { seqüência } & \text { do } \\
\text { trabalho } & \end{array}$ & $\begin{array}{l}\text { Evoluir para } \\
\text { um portal }\end{array}$ & Não informado & Não informado \\
\hline 10 & $\begin{array}{l}\text { Democratização } \\
\text { do acesso e } \\
\text { oportunidade de } \\
\text { participação }\end{array}$ & $\operatorname{sim}$ & Sim & Sim \\
\hline 11 & $\begin{array}{l}\text { Usuário final: } 0 \\
\text { cidadão }\end{array}$ & $\begin{array}{l}\text { Através do } \\
\text { Ippuc }\end{array}$ & $\begin{array}{l}\text { Informação } \\
\text { disponível, } \\
\text { composição de } \\
\text { mapas através } \\
\text { do portal geo }\end{array}$ & $\begin{array}{l}\text { Informação } \\
\text { disponível }\end{array}$ \\
\hline 12 & $\begin{array}{l}\text { Preparação para } \\
\text { a INDE }\end{array}$ & $\begin{array}{l}02 \text { técnicos } \\
\text { no comitê }\end{array}$ & $\begin{array}{l}\text { Baseados em } \\
\text { padrões de } \\
\text { software livre }\end{array}$ & Não informado \\
\hline
\end{tabular}

Quadro 44 - Itens para Avaliação dos Projetos de SIGs Municipais da Região Sul - Capitais Estaduais

O município de Florianópolis usou até 1996 uma base cartográfica de um levantamento aerofotogramétrico de 1979 em escala 1:10.000. A partir de 1997 tendo em vista a desatualização da base produzida em 79, o município iniciou um programa cartográfico digital na escala 1:2.000 e de 1997 a 2004 toda a área foi mapeada com restituição digital. O CTU - Cadastro Técnico Urbano foi implantado em 1982 e desde 
então sistematicamente atualizado sobre as bases gráficas que se seguiram. Esse histórico ocorrido em Florianópolis de vários anos de trabalho sobre mapas desatualizados é muito comum em grandes cidades. São Paulo, por exemplo, durante muito tempo trabalhou com um levantamento de 1972.

O projeto de geoprocessamento iniciou-se em 2003 como integrante do PMAT - Programa de Modernização da Administração Tributária, ele é o passo inicial presente em vários municípios que iniciam o geo para aumentar a arrecadação, principalmente de IPTU. Porém, mesmo sendo esse o intuito inicial, Florianópolis implantou um sólido projeto de geoprocessamento, que pode ser sentido através dos produtos oferecidos no geoportal, http://geo.pmf.sc.gov.br ou www.geofloripa.pmf.sc.gov.br. O município disponibiliza os mapeamentos, de maneira fácil, intuitiva e com importantes ferramentas, como por exemplo, um medidor de distâncias e cálculo de áreas. Existe uma explicação (tutorial) de como usar o software, acesso ao acervo de fotos aéreas do município (mosaicos e ortofotos), toda cartografia temática e facilidades de impressão inclusive com certificação digital de documentos impressos.

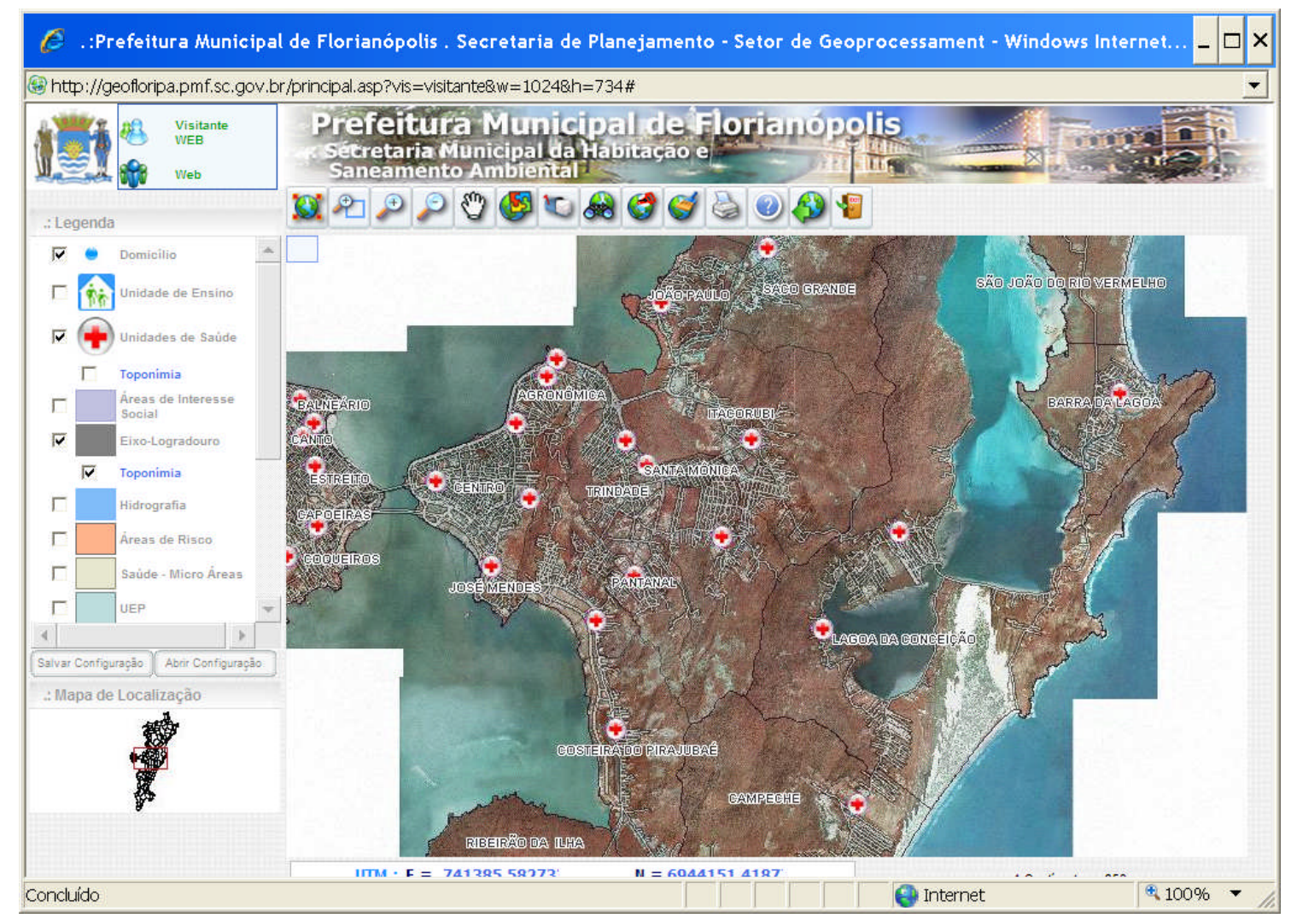

Fig. 08 - Site da Prefeitura de Florianópolis - GeoFloripa

Infelizmente a entrevista por telefone foi curta e o questionário por email não foi respondido até a data do encerramento do trabalho, mas pode-se perceber que 
Florianópolis passou por uma reestruturação de seu modelo de gestão e planejamento através da mudança de paradigma nos processos administrativos, principalmente pelos serviços e produtos oferecidos no site governamental.

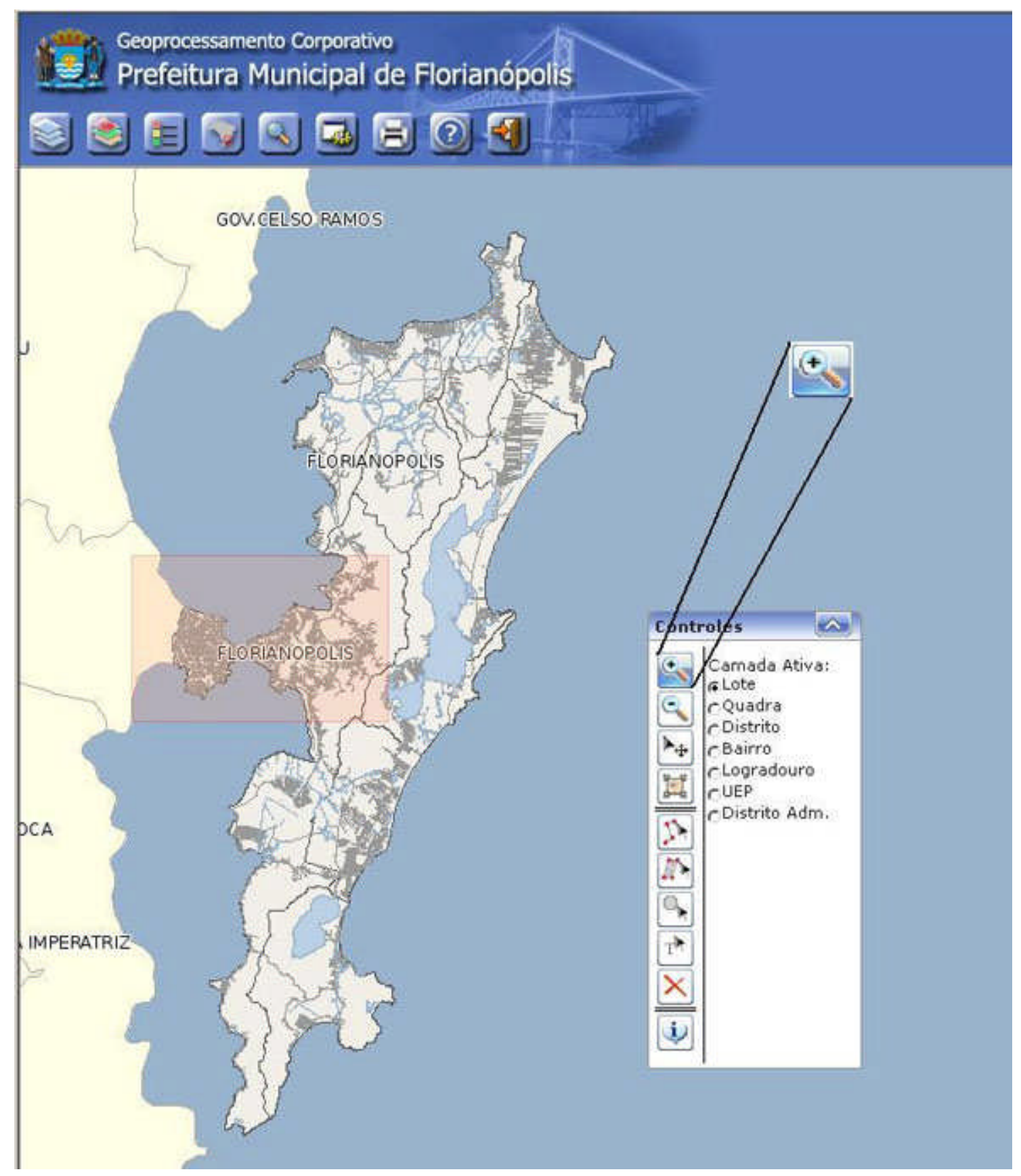

Fig. 09 - Explicação sobre o software de geoprocessamento de Florianópolis

Porto Alegre foi um município que também teve o início dos trabalhos de geoprocessamento no começo dos anos 2000. Houve por parte dos técnicos da secretaria de planejamento palestras para todos os departamentos da prefeitura. 
"É necessário criar uma cultura de geoprocessamento dentro da Administração Municipal, que abranja a maior parte dos funcionários. Um grupo multidisciplinar de técnicos que sabem o que querem é fundamental. A velocidade de implantação depende diretamente do preparo técnico da equipe responsável pelo processo e dos recursos financeiros designados para este fim. Depende também, dos objetivos que forem estabelecidos, isto é, da gama de aplicações a serem desenvolvidas.

A integração do geoprocessamento com os procedimentos administrativos da Prefeitura é o indicador fundamental para a medição do sucesso na implantação do sistema." disponível em www.portoalegre.rs.gov.br/planeja/spm2/12.htm, acesso em 22 de junho de 2009.

Foi criado um Comitê Executivo de Geoprocessamento para a condução dos trabalhos e uniformização das informações. Após algumas tentativas por telefone e emails, não responderam ao questionário. Mas, através da análise de algumas informações no portal da prefeitura e no site da Procempa - Processamento de Dados de Porto Alegre, conclui-se que existe um projeto de geoprocessamento implantado, em que todas as secretarias e órgãos municipais se beneficiam, porém a disponibilização para a Internet ainda esta na fase de interação com poucas operações com os mapas.

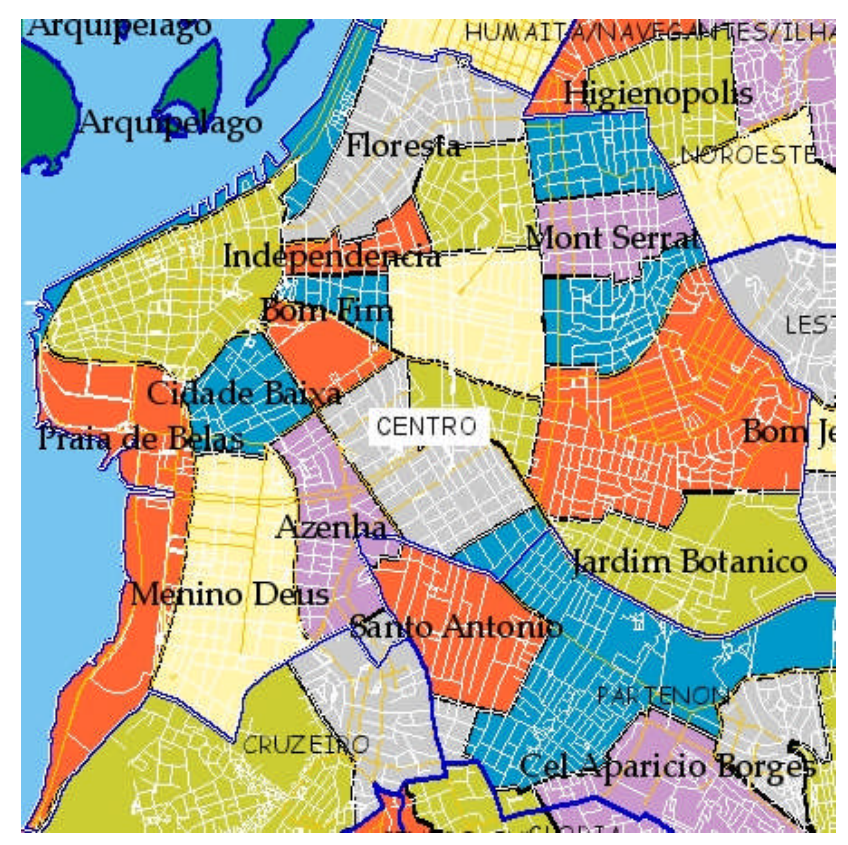

Fig. 10 - Site da Prefeitura de Porto Alegre - Link para Mapa da Cidade.

O Paraná foi pioneiro na iniciativa de se criar um sistema cartográfico para o Estado, porém o projeto não evoluiu, devido a interesses políticos, segundo questionário respondido pela CELEPAR - Companhia de Informática do Paraná. O município de Curitiba foi pioneiro na implantação de geoprocessamento que teve início 
em 1984. Todas as secretarias utilizam um software único, porém a maioria utiliza apenas para consultas e as secretarias de urbanismo, meio ambiente, educação, saúde e recentemente a de abastecimento fazem análise espacial. O SIG não está disponível na internet, mas pelo tempo de uso está bastante disseminado na prefeitura. Cerca de mil máquinas operam o SIG no sistema cliente-servidor. Segundo o Coordenador de Geoprocessamento do IPPUC - Instituto de Pesquisa e Planejamento Urbano de Curitiba, Oscar Schmeiske, o SIG de Curitiba já esteve em melhor fase, o modelo cliente-servidor é antigo, transaciona arquivos ao invés de dados e por isso se torna "pesado". Existe um projeto para que o geo esteja mais disponível à população através do IPPUC, porém ainda precisa passar por atualizações.

No portal do IPPUC ( $\underline{w w w . j p p u c . o r g . b r}$ ) é possível encontrar um link pequeno para mapas digitais de arruamento da cidade. Nesse link não há histórico de desenvolvimento do SIG, ou descrição dos trabalhos como existe em Florianópolis. Existe o Curitiba em Dados, onde disponibilizam recortes em PDF de bairros com arruamentos e principais equipamentos. Esses mapas não permitem que o usuário construa suas cartas com alguma interação. Em outra tentativa de pesquisa, achou-se mais produtos que são vendidos pelo IPPUC: CD-rooms com ortofotos, CD-rooms com mapas da cidade etc..., todos com o preço e o endereço para aquisição.

Através de um contato com o grupo de geoprocessamento do PNAFM do Ministério da Fazenda, foi obtida a relação de alguns municípios que possuem desenvolvimento de SIG. Esses municípios foram citados pelos integrantes do grupo que trabalham na área e não pela Unidade de Coordenação do Programa, que não respondeu ao e_mail solicitado.

São Paulo: Lins - Birigui - Ribeirão Preto - Pirajuí - Tatuí - Porto Feliz - Garça - Pompéia - Tupã - Bariri - Adamantina - lbitinga - Guaiçara - Andradina - Brotas Potirendaba - Ibirá - lacanga - Taquarituba - São José do Rio Preto - Taboão da Serra;

Santa Catarina: Blumenau - Balneário Camburiu - Biguaçu - Canoinhas Garopaba - Herval D’Oeste - Ilhota - Joaçaba - Lages - Luzerna - Palhoça Schroeder - Santo Amaro da Impetratriz - São Bonifácio - São João Batista - Tijucas;

Minas Gerais: Uberlândia - Juiz de Fora - Itabirito;

Rio de Janeiro: São Pedro da Aldeia;

Mato Grosso: Pontes e Lacerda - Tangará da Serra - Colider - Juará;

Pernambuco: Jaboatão dos Guararapes - Arco Verde;

Paraíba: Campina Grande. 
A seguir, a Tabela de Avaliação de Sistemas de Informações Geográficas, disponíveis em portais nacionais:

\begin{tabular}{|c|c|c|c|c|c|}
\hline $\begin{array}{l}\text { Município ou } \\
\text { Estado }\end{array}$ & URL & Presença & Informativo & Interatividade & Transacional \\
\hline São Paulo - SP & www.capital.sp.gov.br & & & $\mathrm{x}$ & $\mathrm{X}$ \\
\hline $\begin{array}{l}\text { Rio de Janeiro - } \\
\text { RJ }\end{array}$ & $\begin{array}{l}\text { www.armazemdedados } \\
\text {.rio.rj.gov.br }\end{array}$ & & & $\mathrm{x}$ & $\mathrm{x}$ \\
\hline Florianópolis - SC & $\begin{array}{l}\text { www.geofloripa.pmf.sc.g } \\
\text { ov.br. }\end{array}$ & & & $x$ & $x$ \\
\hline Palmas - TO & $\underline{\text { www.plamas.to.gov.br }}$ & & $\mathrm{x}$ & $\mathrm{x}$ & \\
\hline Teresina - PI & www.teresina.pi.gov.br & & $x$ & $\mathrm{x}$ & \\
\hline Maceió - AL & www.maceio.al.gov.br & & $x$ & $\mathrm{x}$ & \\
\hline João Pessoa - PB & $\begin{array}{l}\text { www.joaopessoa.pb.gov. } \\
\text { br }\end{array}$ & & $x$ & $x$ & \\
\hline Natal - RN & www.natal.rn.gov.br & & $x$ & $\mathrm{x}$ & \\
\hline \multicolumn{6}{|l|}{ Outras cidades: } \\
\hline Santos - SP & www.santos.sp.gov.br & & & $x$ & $x$ \\
\hline $\begin{array}{l}\text { Balneário } \\
\text { Camburiú - SC }\end{array}$ & www.geocamburiu.gov.br & & & $x$ & $x$ \\
\hline
\end{tabular}

Quadro 45 - Itens de Avaliação de SIGs em Portais Municipais - Nacionais

\subsubsection{Portais Internacionais de SIG na Internet}

A intenção da análise dos portais de Sistemas de Informações Geográficas fora do Brasil foi realizada no intuito de identificar se existem produtos disponíveis para a população no mesmo nível de desenvolvimento brasileiro, ou não. Não foram levados em consideração aspectos do contexto político e cultural desses países, nem o tamanho populacional ou geográfico. As análises foram simples, através de visitas aos sites, tentativas de imprimir mapas e de realizar alguma operação. A seguir, destacam-se os comentários sobre o que foi possível encontrar em suas políticas de aplicação da geoinformação:

\section{Estado de Nova lorque \\ www.nygis.st.gov \\ Histórico: \\ - Início em março de 1996, com o Conselho Temporário de Informações} Geográficas que emitiu um relatório analisando as questões relativas à informação geográfica e várias recomendações para melhorar a posição competitiva do Estado através do SIG;

- O Instituto de Tecnologia OFT, foi convidado a implementar as recomendações e identificar as necessidades dos governos locais, através de encontros de discussão.;

- Com base nestes encontros que reuniram governos locais, agências estatais e setor privado, foi criada uma política tecnológica que instituiu o 
Programa de Coordenação NYS GIS, em setembro de 1996.

- Grupos de trabalho se reuniram regularmente e criaram o GIS Clearinghouse, que evoluiu de uma página na Internet de informações SIG para um composto de vários arquivos, ligações e repositório de metadados que estavam disponíveis na web.

A partir desses dados, criou-se a necessidade de formar uma cooperativa de partilha de dados SIG, atualmente composto por 300 membros do governo e tornou-se a peça central do programa.

- Em 1998, a partilha de cerca de 8.500 dados foram avaliados em US\$ 2.000.000. Em 2.000, mais de 300.000 dados foram avaliados em US $\$ 12.000 .000$.

- Além de diversas análises de custo benefício, treinamentos em metadados de SIG foram realizados para mais de 400 pessoas em 10 cidades no estado todo e também colocado o treinamento on-line.

-Ainda em 1998, foi elaborada a legislação de incentivo à partilha de dados, permitindo licenciamento de dados GIS, sancionada em 2000.

- Em 1999, o Grupo de Trabalho de Finanças, concluiu o documento intitulado "Fontes de Financiamento SIG" para os governos locais.

- Em 2000, foi criado um aplicativo de mapeamento SIG na Internet com uso de ortofotos digitais, pioneiro no país.

- Em dezembro de 2000, foi criado o OFT NYS Centro de Informação Geográfica. Sua função foi facilitar o uso do SIG pelos governos estaduais e locais, ficar responsável pela modernização e integração de dados SIG, atualizando as bases gráficas e de dados. Redesenhar o SIG Metasite para melhorar a usabilidade e desenvolver um armazém de dados espaciais. Esse entreposto elimina as necessidades dos governos e de agências de governo a terem capacidade de armazenamento para grandes conjuntos de dados.

- O Centro é responsável pela formação de funcionários de governo, através de oficinas em todo o Estado e também linhas de formação à distância. Também é responsável pela comunicação entre as agências de governo, bem como universidades e setor privado para discussão de questões relativas ao SIG. Criaram um GIS Help Desk on line para os membros da partilha de dados do GIS NYS.

- O corpo de coordenação revisa sua estrutura anualmente. Promove uma sessão para analisar as realizações do ano passado e a priorização de 
tarefas para o próximo ano.

- Em agosto de 2008, foi lançado um plano de "Cooperativa Estratégica para Construir e Manter a Infraestrutura de Dados Espaciais", foco do esforço estadual de planejamento estratégico. Para garantir que um conjunto de dados geoespaciais de alta qualidade esteja disponível para todos os interessados no SIG de Nova lorque nos próximos anos. Esforço organizado pela coordenação do programa GIS NYS, liderado pelo Escritório de Coordenação de Cibersegurança e Infraestruturas Críticas (CSCIC) e financiado pelo Federal Geographic Data Comitê (FGDC).

- A Política para SIG de 1996, estabelecia, entre outros itens, que os encargos com o desenvolvimento de um organismo de coordenação estadual, permitiria a transferência de dados digitais entre os governos estaduais e locais a custo reduzido ou nulo.

- Essa política foi enviada a todas as agências estatais e estabeleceu diretrizes para desenvolvimento do programa. Governos locais, estaduaais e o setor privado consultivo, formaram grupos para contribuírem com questões específicas e em poucos meses, tiveram a ClearingHouse com bibliotecas estabelecidas, normas iniciais aprovadas, legislação necessária para eliminar os inibidores e um olhar para o mercado financeiro e um campo de possibilidades do SIG no Estado de Nova lorque.

Acesso em 16/06/2009

Quadro 46 - Histórico do SIG do Estado de Nova lorque 
Tabela de Avaliação de Sistemas de Informações Geográficas, disponíveis em portais Internacionais:

\begin{tabular}{|c|c|c|c|c|c|}
\hline $\begin{array}{l}\text { Município ou } \\
\text { Estado }\end{array}$ & URL & Presença & Informativo & Interatividade & Transacional \\
\hline $\begin{array}{l}\text { Nova lorque - } \\
\text { Estado }\end{array}$ & www.nygis.state.ny.us & & & $x$ & $x$ \\
\hline $\begin{array}{l}\text { Nova lorque - } \\
\text { Cidade }\end{array}$ & www.nyc.gov/citymap & & & $x$ & \\
\hline Boston & www.cityofboston.gov/maps/ & & & $x$ & $x$ \\
\hline Lisboa & $\underline{\text { www.cm-lisboa.pt }}$ & & & $x$ & $x$ \\
\hline Pequin & $\begin{array}{l}\text { www.ebeijing.gov.cn/beijingi } \\
\underline{\text { nfo }}\end{array}$ & $x$ & & & \\
\hline Roma & www.comune.roma.it & $x$ & & & \\
\hline Berlim & $\begin{array}{l}\frac{\text { http://www.newberlin.org/go }}{\text { vernment/departments/com }} \\
\text { munity-development/gislis- } \\
\text { services.aspx }\end{array}$ & & & $x$ & \\
\hline Seul & $\begin{array}{l}\text { http://map.wooricy.com/Seo } \\
\text { ulMapEngN/ }\end{array}$ & & $x$ & $x$ & \\
\hline Montreal & $\begin{array}{l}\text { http://ville.montreal.qc.ca/por } \\
\text { tal// }\end{array}$ & & $x$ & $x$ & \\
\hline Tóquio & $\begin{array}{l}\text { (www.metro.tokyo.jp/ENG } \\
\underline{\underline{\text { ISH }})}\end{array}$ & & & & \\
\hline
\end{tabular}

Quadro 47 - Itens de Avaliação de SIGs em Portais - Internacionais

O portal interativo do Estado de Nova lorque dá acesso a ortofotos digitais do Estado. Visitantes podem visualizar e descarregar imagens. Há links para metadados, download direto e mais opções. No aplicativo de mapeamento, existem ferramentas de navegação, capacidade de busca extensiva e várias opções de mapeamentos. Podem ser criados mapas personalizados e impressos, imagens visualizadas e dados copiados para uso em um SIG. Além de links para o Programa de Alta Resolução de Ortofotos, perguntas freqüentes, ajuda e um glossário. 


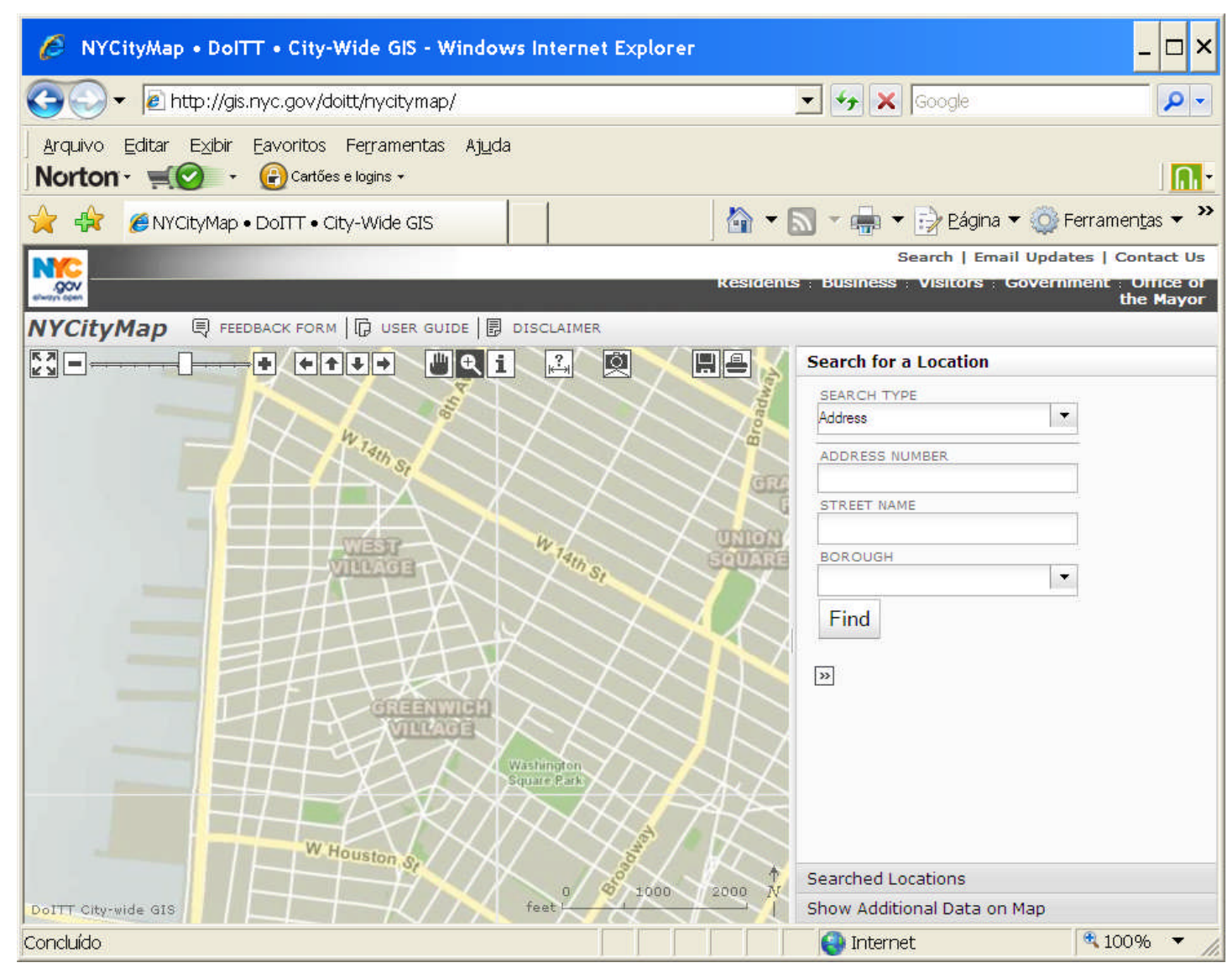

Fig. 11 - Site Oficial da Cidade de Nova lorque - Link para o geoprocessamento

O SIG da cidade de Nova lorque disponível na Internet tem algumas ferramentas básicas como zoom in, out, pan. Tem localizadores de endereços e equipamentos, possibilita imprimir, visualizar mapa ou visualizar uma excelente qualidade de fotografia aérea.

Os recursos do SIG de Boston são parecidos com os da cidade de Nova lorque, com alguns recursos a mais, como medidor de distâncias e áreas. $O$ mapa ou a visualização em fotografia aérea podem ser impressas e enviadas por email. Dentro do SIG, encontra-se três diretórios:

- Visualizador de dados do imóvel, permite aplicar zoom em uma parcela específica e encontrar informações sobre a propriedade, construção, avaliação do terreno, tamanho, etc...

- Visualizador de dados do Bairro, através desta ferramenta é possível encontrar equipamentos e serviços do bairro, como biblioteca, centros de saúde, centro comunitário e distância entre eles.

- Visualizador de projetos da cidade, permite ver os projetos do plano qüinqüenal da cidade de Boston. Pesquisa por bairro, distrito ou estatuto e receber uma descrição do orçamento e de trabalhos previstos. 
O site da Câmara Municipal de Lisboa tem na página inicial um link para o mapa de Lisboa que é um portal com ferramentas SIG, denominado Lisboa Interactiva. O SIG disponibiliza várias ferramentas como zoom in, out, pan, identificar, marcar ponto, utilidades, limpar seção, trajecto pedonal, trajecto rodoviário, medir, imprimir, ortofoto, mostrar legenda, mapa de enquadramento, itens para pesquisa avançada. Também possui boa qualidade da imagem de ortofoto.

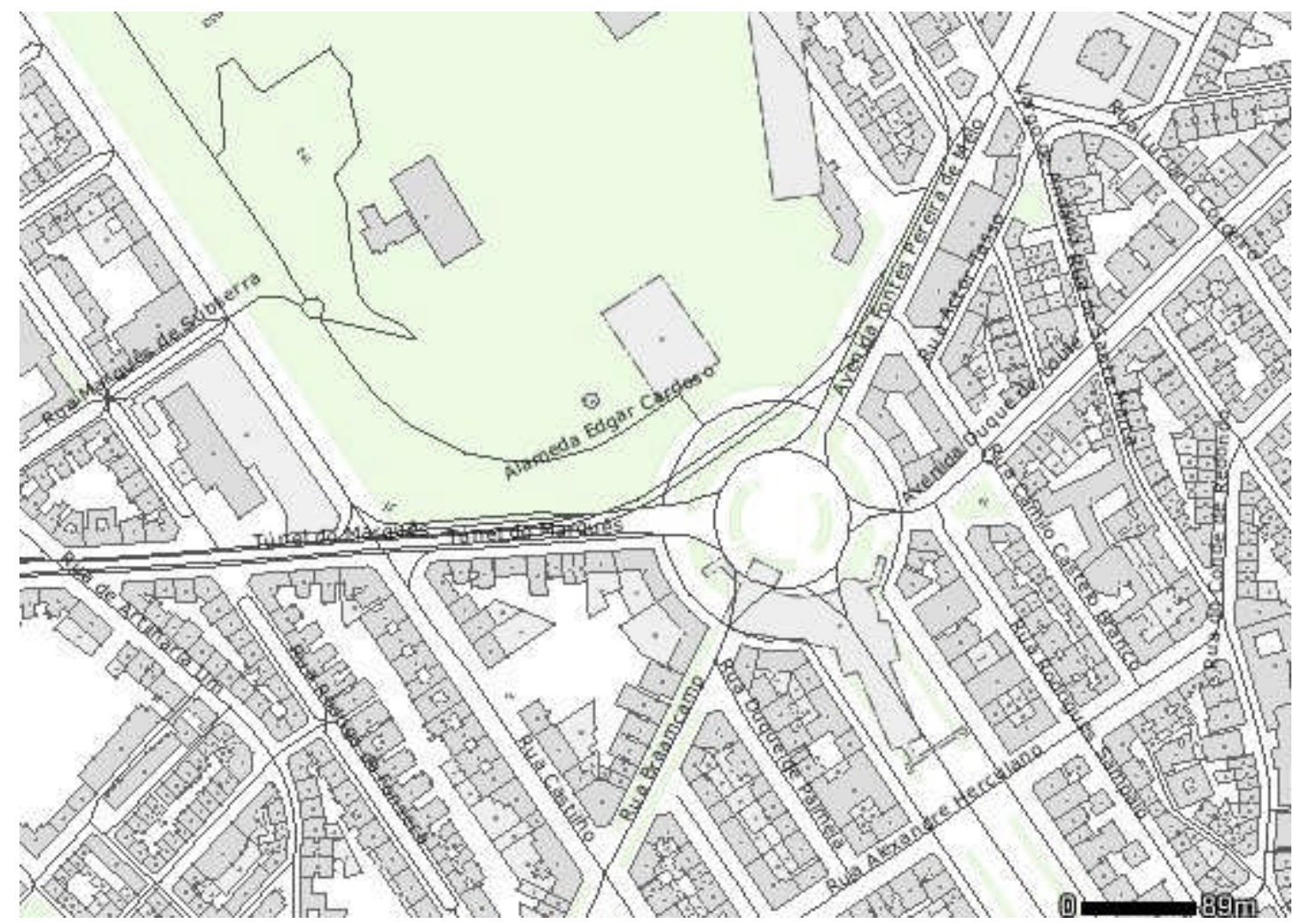

Figura 12 - Mapa do SIG Lisboa

No site da cidade de Pequin, China, acesso pelo endereço (www.ebeijing.gov.cn/beijinginfo), foi encontrado com dificuldade um link para mapas, porém, ainda no estágio de desenvolvimento de presença, apenas disponíveis mapas de um determinado tema, sem ferramentas. Conforme exemplo: 


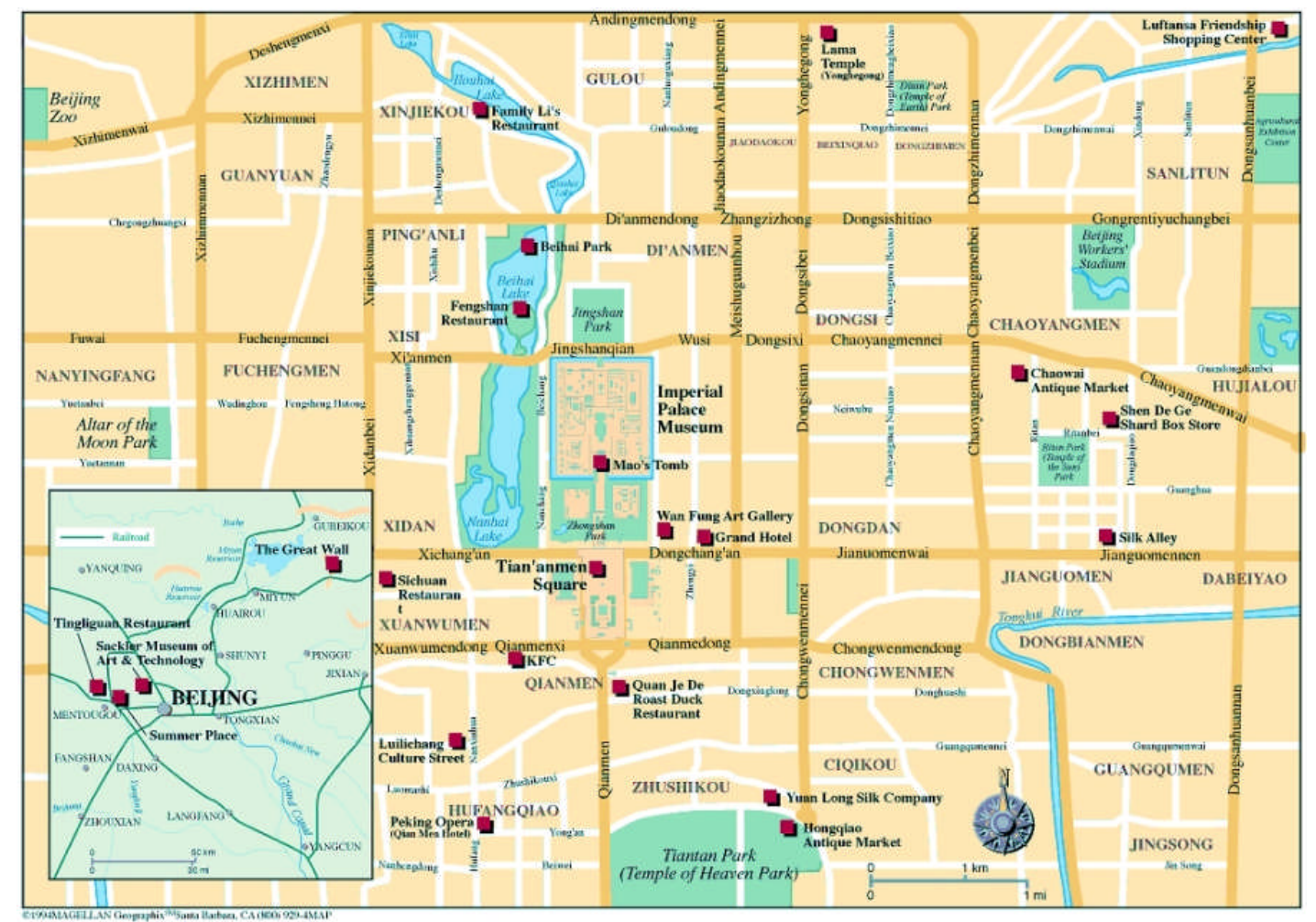

Fig. 13 - Mapa de Pequim disponível no site municipal

No site oficial da cidade de Tóquio no Japão, (www.metro.tokyo.jp/ENGLISH), pode-se notar a presença de informação exagerada, causando confusão de dados. Foi pesquisado da mesma forma como em outros sites de governo, como não havia link para mapas na página inicial, usou-se a ferramenta de busca, pesquisando sobre mapas ou SIGs e nada foi encontrado.

Um item bastante presente nos sites municipais em várias partes do mundo é o da participação popular, o que reforça a questão da e-democracia. 


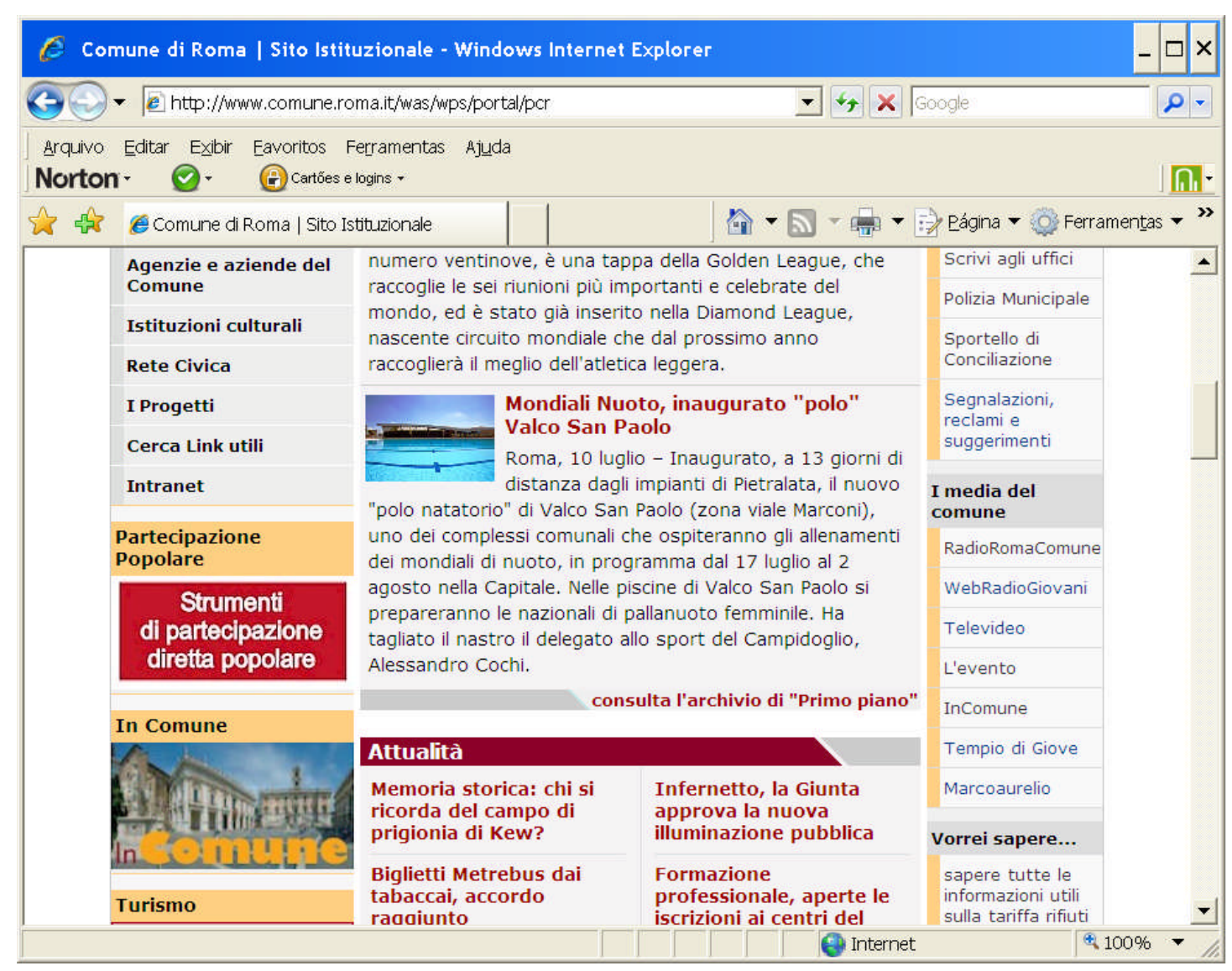

Fig. 14 - Link para participação popular no site de Roma

Em ( www.comune.roma.it), acesso em 20/06/2009, não existe link para mapas e os poucos que existem estão na fase de presença. Esse da cidade de Roma, para fazer qualquer zoom é necessário instalar um programa para download.

Após pesquisa sobre o SIG em Londres, encontrou-se uma discussão sobre a criação do "Virtual London", que aponta mais uma direção no futuro do SIG: a cidade no modelo 3-D. Até pouco tempo, os modelos 3-D eram criados em CAD (Computer Aided Design), mas já existem modelos 3-D em SIG, onde possibilita análises de estatísticas, níveis de poluição, aumento do nível do mar, entre outras aplicações. 


\section{Novas evoluções do SIG}

O objetivo do Londres Virtual a pedido do Greater London Authority (GLA) é desenvolver a melhoria da divulgação de informações de planejamento. Em seguida, alegam que cidades virtuais devem ir muito além das concepções tradicionais de 3-D CAD e SIG, em mundos virtuais e de desenho on-line. Há a preocupação de levar a mensagem digital para cada vez mais longe. Pois, existe uma demanda de modelos de forma mais realista e familiar de representações às pessoas de um modo geral.

Há muito tempo existem manifestações da cidade representada em 3-D, mapas antigos de cidades com casas e edifícios públicos mostrados em perspectiva oblíqua, por serem mais facilmente assimilados do que desenhos planos. Hoje em dia, em parte pela tecnologia e em parte pelas expectativas públicas, técnicas digitais vem sendo usadas para as representações 3-D. A mídia digital e jogos de computador são responsáveis por alimentar essa demanda. O resultado é que em muitos casos os mapas bidimensionais já não são o suficiente para comunicar idéias espaciais.

Embora o SIG 3-D já esteja disponível por algum tempo. O CAD apresentava mais facilidade de uso, uma interface mais intuitiva com o usuário, tamanhos de arquivo mais compactos e pacotes como Autocad e 3-D Studio Max ainda emergem como os preferidos. Ao longo dos últimos 5 anos, a indústria de software SIG tem aumentado o nível de 3-D embutidos em seus pacotes. A indústria de jogos de computador tem avançado muito nas visualizações 3-D e aumentado os níveis de realismo, estando a vários passos à frente. Alguns autores argumentam que o SIG 3-D só seria realmente útil quando se puder manipular e gerenciar dados SIG e também derivados de modelos CAD. Esse objetivo foi recentemente alcançado através da criação de um modelo 3-D do centro de Londres, que integra os dados com base no SIG e modelos derivados do CAD e explora software de jogos de computador, para fornecer um produto que pode ser extremamente poderoso quando visualizado em um computador e poderá ser usado através da Internet.

Exemplos de alguns modelos 3-D de Londres foram construídos por diversas entidades nos últimos anos, segue uma amostra desses modelos, sem comentários de suas características para não prolongar esta pesquisa. 


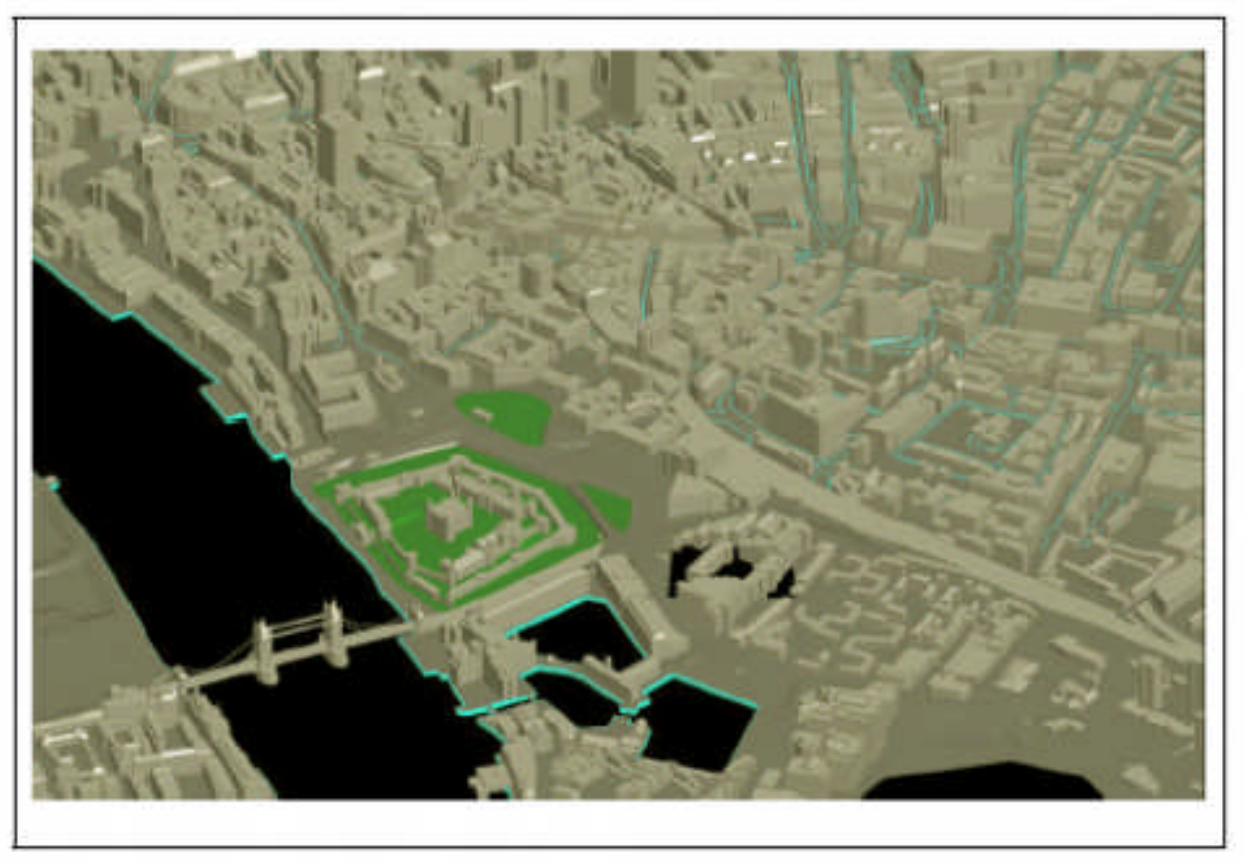

Modelo 3-D - A Cidade Universitária

\section{A construção do Londres Virtual}

A Londres Virtual é uma parceria entre a Greater London Authority (GLA), com os contratantes, a British Telecom, Londres Liga e a Corporação de Londres, sob um governo central para a iniciativa conhecida como "e-democracia". O objetivo desta iniciativa é o de aumentar os níveis de participação dos cidadãos no processo democrático em um nível local e regional, e para testar o papel das tecnologias avançadas na consecução desse objetivo. A idéia é explorar uma gama de ferramentas inovadoras, - que irá estimular a participação nos processos democráticos, um componente essencial na criação de um sentido de cidadania. O estudo analisa como a nova tecnologia desempenha o papel de ligação do público em geral com os decisores políticos, e 
se as novas tecnologias podem ajudar a engajar partes da comunidade que a social, econômica ou cultural, não tomavam parte nas formas tradicionais de consulta pública.
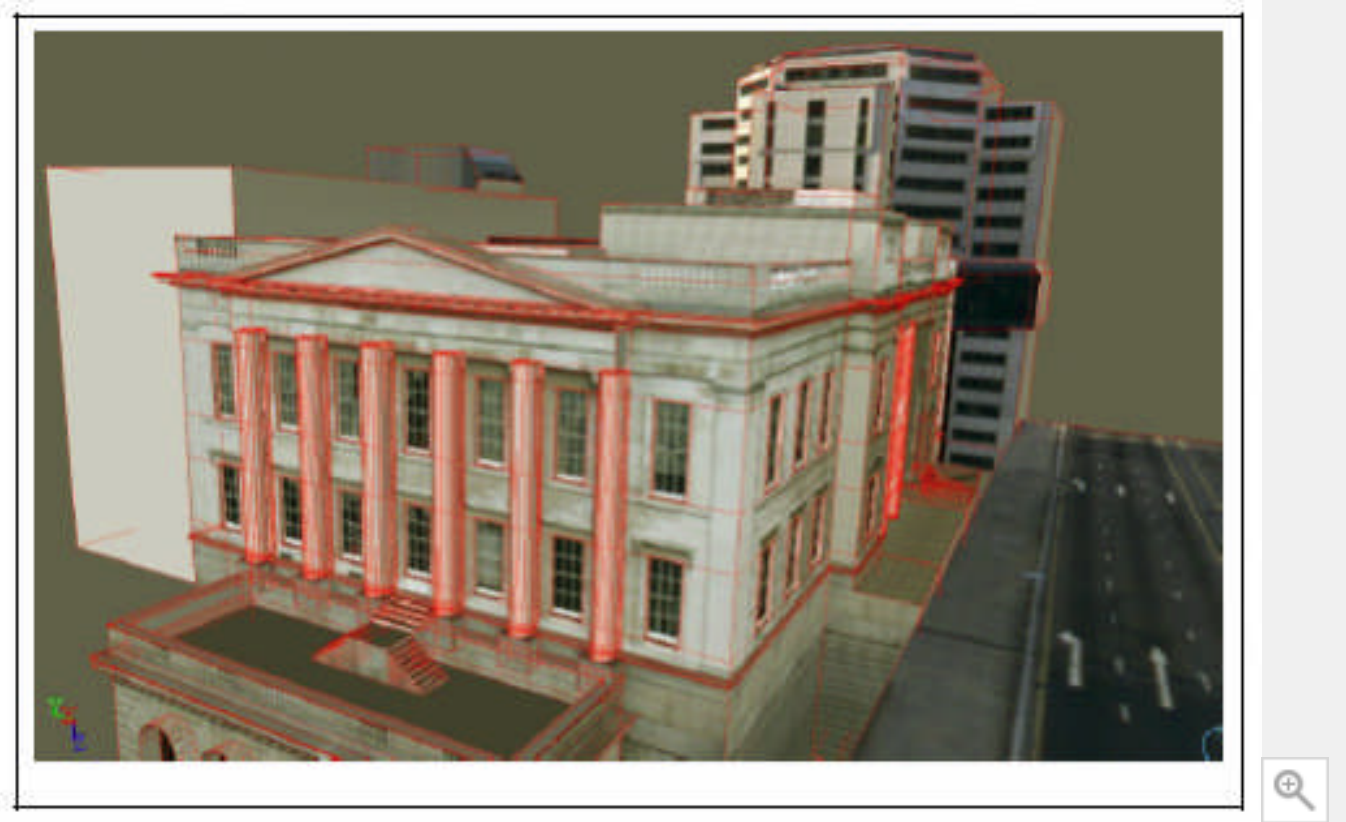

Fishmongers Hall ao lado de London Bridge - um dos edifícios marcos sendo modelado em RealViz Imagemodeler

As primeiras pessoas a verem o trabalho do Londres Virtual ficaram impressionadas com os detalhes geométricos dos edifícios e dos terrenos, porque os modelos anteriores da cidade estavam centrados em representação arquitetônica e tinham pouca noção sobre como adicionar outras camadas para o modelo. Atualmente, o Londres Virtual começou a desenvolver novas camadas de informações que podem ser integrados no modelo atual. No primeiro, destacou nomeadamente edifícios, por exemplo, os edifícios construídos nos últimos 10 anos ou menos. Então, foi acrescentado fronteiras administrativas para mostrar onde cada fronteira de governo local começou e terminou. 

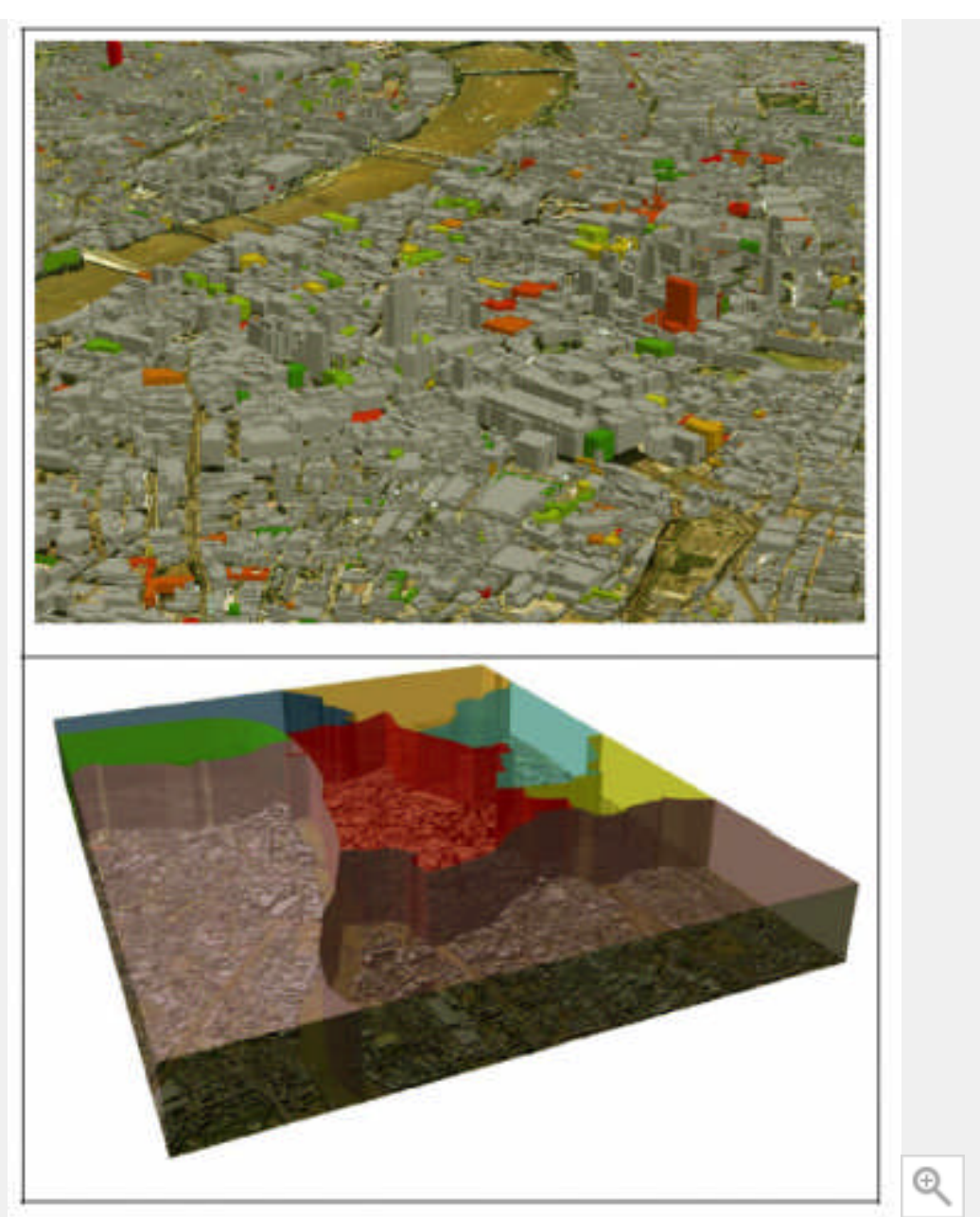

Na figura, edifícios inferior a 10 anos (construção) pode ser identificada no modelo (vermelho são as mais recentes, através de verde como 10 anos (cinzento blocos são> 10 anos). Acima, mostra fronteiras administrativas dentro do modelo

Um outro conjunto de dados que revelaram um índice interessante foi a vitalidade do sucesso comercial de partes da cidade. Esse conjunto de dados foi lançado ao longo do modelo, a fim de ser capaz de visualizar a vitalidade dos "centros urbanos". Esse trabalho lançou, em seguida, mais ideias como um aumento do nível do mar de 5 metros, que foi desenvolvido para mostrar a extensão da inundação, no caso do aquecimento global ser adicionado. 


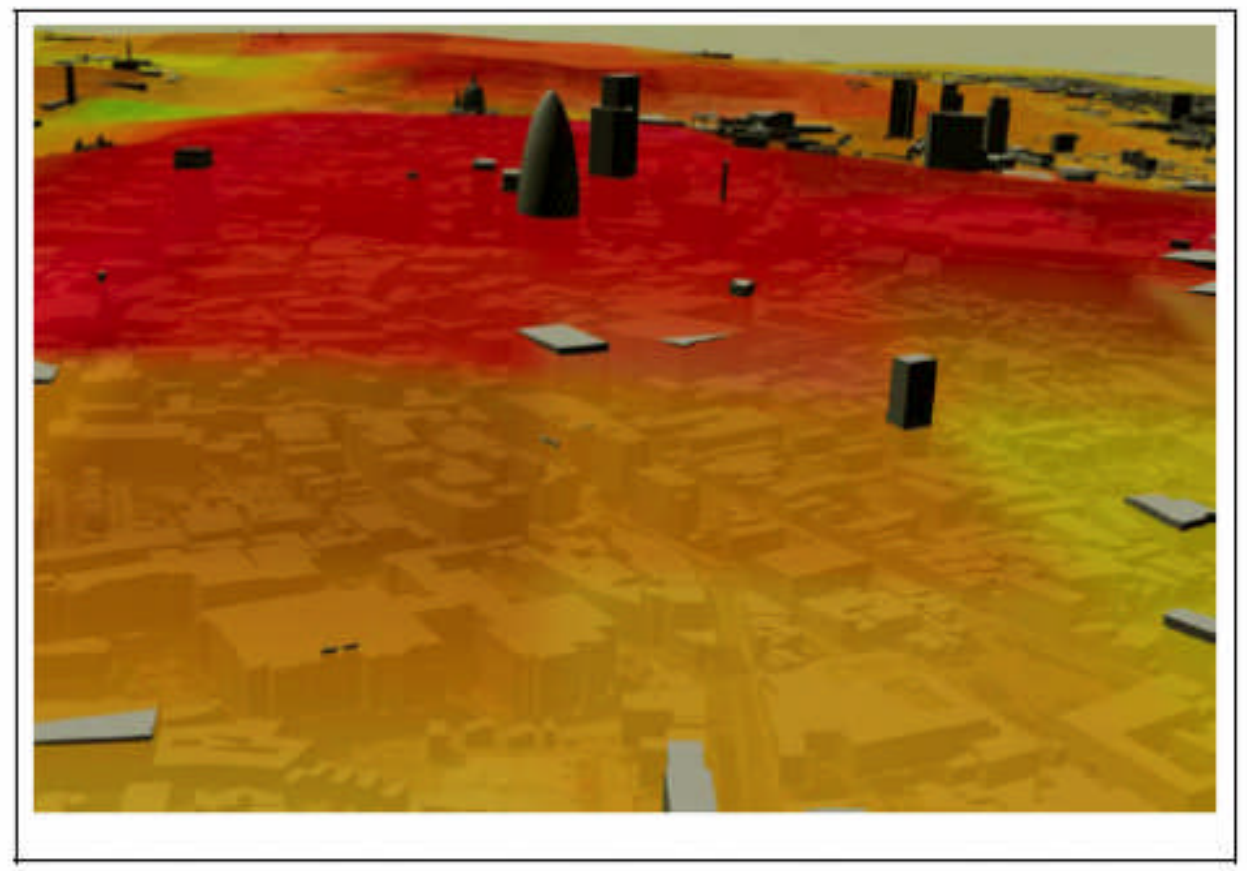

Índice de «centros urbanos» mostra em vermelho as áreas que são comercialmente mais produtivos, enquanto em laranja e amarelo, através de zonas verdes são os que têm menores rendimentos comerciais.

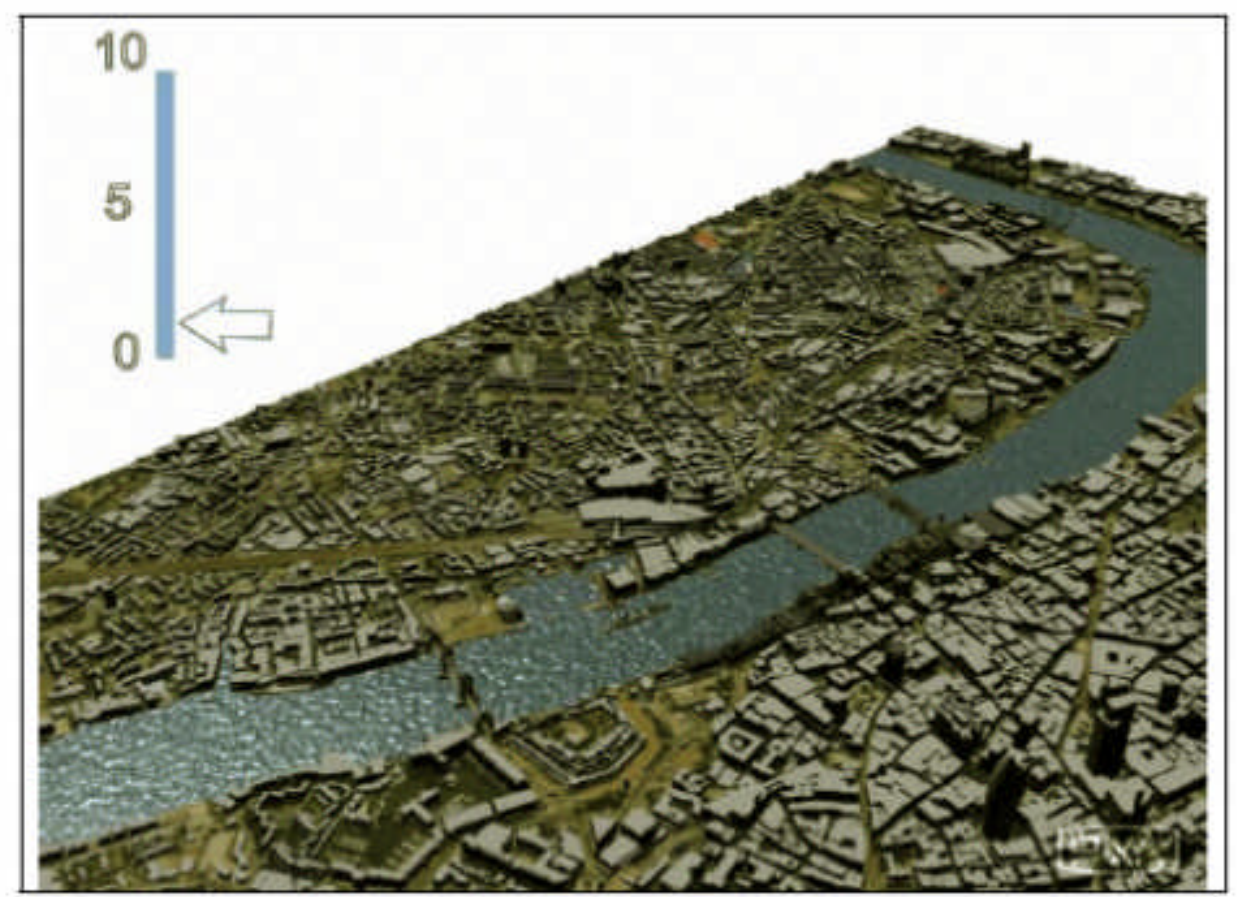

Alterações do nível do mar pode ser simulado no modelo

Em colaboração com o Grupo de Pesquisa Ambiental (Kings College de Londres), aos dados de poluição do ar foi adicionado a representação do óxido de azoto (NOx). Essa camada utiliza dados de todas as fontes de emissões em 
Londres, mas é claramente dominado pelo tráfego rodoviário. Os números são processados para calcular uma média diária total para o poluente. A equação para o modelo de NOx, é calculada a partir de um carro em movimento. Perfis de idade dos veículos são tomados a partir dos modelos em circulação nacional do Reino Unido. As emissões usam um modelo de dispersão e são validadas através da extensa base de dados de medição da qualidade do ar em Londres.
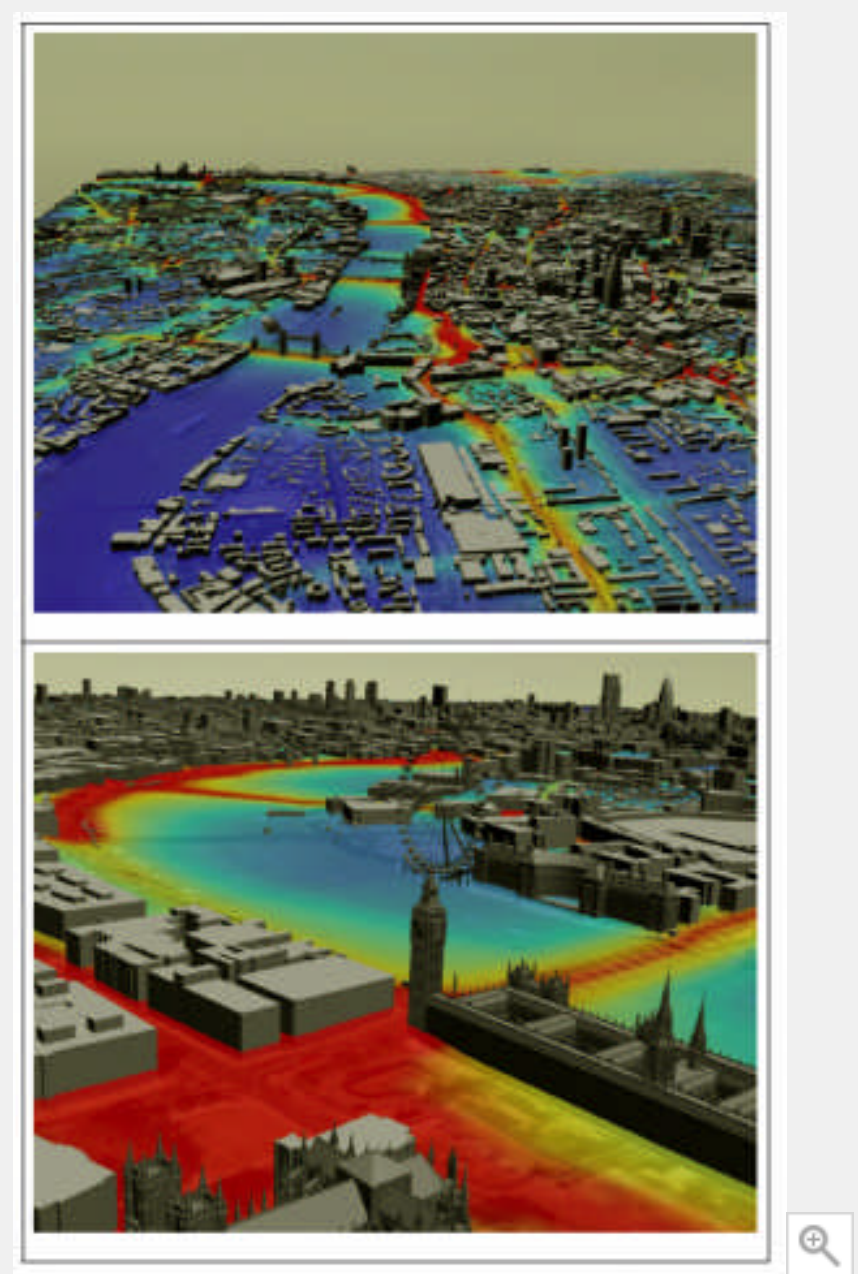

O óxido de azoto (NOx) a poluição do ar (média anual prevista para 2005) simulada como uma camada dentro do modelo. Este poluente, muitas vezes apelidado de "urbanization smog's" em grande parte são provenientes de emissões dos veículos. Vermelho revela níveis mais elevados, enquanto azul representa os níveis mais baixos (dados de Environmental Research Group, Kings College de Londres)

Outras informações poderão ser marcadas nos edifícios. Por exemplo, o floorspace, os nomes das empresas, a utilização da energia, o número de pisos (para ajudar serviços de emergência quando responder a um incidente) e assim por 
diante. Utilização dos solos seria outra camada chave a adicionar. Níveis de tráfego, níveis de ruído, bem como a localização dos centros de transporte interessariam muito as pessoas. Dados socio-económicos são uma outra faixa de informações que pode ser útil para o público, urbanistas e similares. E, naturalmente, essas camadas não tem que ser restritas aos acontecimentos "acima do solo". Redes poderiam ser adicionadas abaixo do modelo, tais como esgotos, telefone, gás e outras redes, o que poderia abrir as possibilidades de utilizar o modelo de "realidade aumentada", por exemplo, para fins de visualizar características "enterradas".

Stephen Evans, Andrew Hudson-Smith e Michael Batty, «3-D GIS: Virtual em Londres e mais além», Cybergeo, a selecção dos melhores artigos de SAGEO 2005, artigo 359, última modificação em 04 jullho de 2007

Quadro 48 - Novas Evoluções do SIG - Londres 3-D

Disponível em http://www.cybergeo.eu/index2871.html, acesso 24 de junho de 2009. 


\section{CONSIDERAÇÕES FINAIS}

Uma frase que pode sintetizar a intenção da pesquisa:

Nós somos a primeira geração que está aprendendo a viver em uma sociedade cosmopolita global, diferente de todas as sociedades anteriores (GIDDENS, 2008, p. 24).

No presente estudo, o ponto mais importante a ser destacado é a questão da comunicação. A globalização, tão discutida no mundo hoje, não é só um fenômeno econômico, é acima de tudo, um fenômeno de comunicação. A evolução tecnológica dos últimos 30 anos, dos computadores, das redes e dos satélites, faz com que exista a comunicação instantânea em todo lugar e isso é diferente de tudo o que já existiu antes. É claro que afeta a vida cotidiana. Existe uma espécie de sociedade cosmopolita global se formando, onde a informação é o que une as pessoas. Os governos se transformaram ao longo dos tempos, novos ideais se formam, não existe mais o socialismo radical, pois ficou claro que não era a solução, também ficou ainda mais claro, depois da crise financeira mundial, que a filosofia do mercado neoliberal não se sustentou. É preciso achar um ponto de equilíbrio, uma discussão que não se restringe a ideais políticos ou sistemas econômicos e que de fato conduza a humanidade a um período com mais distribuição de benefícios como um todo: saúde, educação, alimentação, renda etc. O que está começando a surgir é uma espécie de sociedade mundial, não uma formação de lideranças políticas, mas de uma sociedade única. Vê-se, por exemplo, inúmeras organizações não-governamentais que se formaram e que conseguem atingir uma comunicação mundial. Um evento localizado em qualquer parte do planeta rapidamente é comunicado e as pessoas têm acesso em tempo real. O que se observa aqui é que governos estão se preocupando mais em terem transparência e o principal, diálogo com cidadãos. Isso está presente na maioria dos países. É interessante notar que os sites governamentais têm as mesmas preocupações: oferecer serviços, informar e formar uma via de comunicação. Nunca se teve antes acesso às administrações como hoje e percebe-se que este fenômeno é crescente, não vai retroceder.

Nesse cenário novo, a informação geográfica alcança valores imensuráveis. O avanço tecnológico dá oportunidade real de melhores aplicações de políticas e de ações. $E$ isso pode ser mostrado tanto através do governo eletrônico como no aumento da qualidade dos diagnósticos de análise territorial, onde ambos atingem mais e mais a população.

Observou-se nesta pesquisa que para garantir o êxito de um projeto de governo que englobe várias esferas e que realmente melhore a qualidade de vida de 
sua população, seguindo os novos paradigmas em administração pública e fazendo uso das mais modernas aplicações em TIC, associadas aos benefícios das informações espaciais, requerem o cumprimento de uma série de condições consideradas fundamentais, a seguir concluídas nesta pesquisa:

Diagnóstico da situação atual:

É importante identificar qual o nível de preparação que se encontra determinado governo. Qual é a situação atual dos levantamentos cartográficos, bancos de dados, projetos em andamento, equipamentos, softwares, recursos humanos, telecomunicações e recursos financeiros.

Analisar as melhores práticas:

Identificar melhores práticas tanto nacionais, como internacionais e assimilar aprendizados. Estabelecer padrões a serem alcançados, ter bem clara a idéia das metas a serem atingidas.

Analisar as melhores tecnologias:

Analisar todos os softwares disponíveis no mercado, para que seja escolhido o que melhor se adapte àquela administração. Contar com assessorias para implantação e treinamento em geoprocessamento. Criar uma cultura interna da geoinformação entre todos os funcionários do governo e também seus líderes.

Elaboração de um plano de Ação:

Estabelecer um plano, que pode ser ambicioso, porém com metas claras, definidas para curto, médio e longo prazos e execução gradual.

Comprometimento forte de um líder de governo:

Mesmo em administrações municipais, é necessário que se forme uma liderança para criar e cumprir as etapas de implantação de uma gestão apoiada em tecnologias, tanto no governo eletrônico como nos projetos de geoprocessamento.

Ouvir todos os envolvidos no Processo:

Consultar os diversos usuários da administração pública, tanto os internos (servidores) como os externos (cidadãos), sobre a qualidade do serviço, necessidades ainda não cobertas e formas de melhorar o atendimento. 
Realizar um projeto integral:

Para que haja um profundo impacto e que realmente atinja a qualidade de vida da população, deve-se realizar um projeto de implantação que englobe todas as áreas de governo: habitação, saúde, educação, segurança, meio ambiente, atividades econômicas e ainda investir na formação de recursos humanos e integração entre as secretarias.

Mudança na organização interna do órgão:

Antes do projeto ficar disponível para a população, é necessário que os processo internos sejam revistos, reestruturados, que a organização passe por uma modificação de conceitos, objetivos, metas e estratégias. Pensar em um governo voltado para a população.

\section{Comunicação e Liderança:}

Deve-se focar uma série de ações orientadas a comunicar os objetivos, alcances e benefícios do projeto em questão. Também deve-se avaliar, explicar, treinar, obrigar, receber retroalimentação, premiar, estimular e compartilhar as boas experiências.

\section{Democracia Digital:}

Levando-se em conta a participação popular, a consulta pública, o envolvimento nas decisões políticas, cadastros, informação disponível, entre outras possibilidades, a Internet está favorecendo uma imensa possibilidade de usos da tecnologia com impacto político.

Cita-se alguns exemplos:

- Campanhas e financiamento (Partido Democrático - EUA);

- Inscrição Eleitoral (Coréia e Austrália);

- Comunicação entre representantes e votantes (Japão, EUA e Canadá);

- Participação na Agenda Legislativa (Singapura e EUA);

- Eleições e votações (Brasil, Paraguai e Inglaterra).

O estudo identificou uma série de fatores críticos de sucesso para o desenvolvimento de um SIG municipal. A abrangência da proposta, o número de entidades envolvidas, o impacto social e econômico, o prazo necessário para seu desenvolvimento e a dimensão do investimento, podem classificá-lo como estratégico. Sendo assim, torna-se necessário e fundamental o apoio político, a capacidade de liderança, a qualidade da equipe técnica e de gestão e os recursos financeiros 
adequados. Também é preciso assegurar o envolvimento de várias entidades, incluindo organismos públicos, seus servidores, empresas e cidadãos. A divulgação da cidade através de mapas de análises espaciais por meio dos canais de governo eletrônico é um importante fator de promoção de iniciativas de melhoria dos serviços prestados pela administração municipal.

Com este estudo, conclui-se que as etapas de desenvolvimento de um projeto de modernização da administração pública municipal através das tecnologias de Informação e comunicação quando somada às geotecnologias torna-se ambicioso, agregador e capaz de potencializar o desenvolvimento de uma cidade.

Nota-se que o planejamento e a gestão estratégica têm sido as respostas que se mostraram mais adequadas ao novo perfil de gestão pública que a sociedade tem demandado.

As questões territoriais, políticas, econômicas, de meio ambiente e de gestão têm constantemente desafiado os municípios. Exigindo um avanço nas técnicas de planejamento comumente usadas pelos administradores.

Mas o mais importante concluído aqui, através das entrevistas em diversos municípios, nota-se que o planejamento não é uma atividade meramente técnica, mas é principalmente política. Ouvir opiniões, escutar as demandas são de extrema importância e os planejadores não devem ficar restritos ao ambiente dos gabinetes, pois não dá para saber tudo através de análises de computadores. É necessário que a população participe na identificação dos seus problemas, na cobrança, na avaliação crítica; aos técnicos cabe assessorar, apresentar soluções e é através do diálogo que há a busca de soluções. Há tempos já se sabe que a realidade não pode ser totalmente reproduzida por softwares, tecnologias, etc., mas também não se pode ignorar o quanto esta informação precisa encurta os caminhos na busca por uma cidade mais justa.

Pensar projetos de governo-eletrônico a partir do ponto de vista dos cidadãos, incluindo as informações espaciais, é um elo importante no processo administrativo e implica num projeto de governo voltado a atender as pessoas, facilitando procedimentos que antes eram burocráticos, alem disso, promove a transparência em suas ações, canais de comunicação, tudo voltado para a melhoria e aumento dos serviços prestados. Disponibilizar mais informações fortalece a confiança no governo e fornece dados para a tomada de decisões também no setor privado.

Por isso, os governos devem prever canais de comunicação com seus cidadãos. Devem ter conhecimento das carências, problemas, sugestões da 
população. Como o meio digital aproxima pessoas e organiza os dados recebidos, é preciso que os sites governamentais tenham espaço para essa comunicação.

Nos casos estudados, o apoio do governo e a credibilidade que a população tem nos sites governamentais são fundamentais para o sucesso alcançado.

Não se pode esquecer que o processo de inclusão digital vem aumentando, porém somente $14 \%$ da população brasileira tem acesso a computador com Internet. Essa preocupação pode ser minimizada de diversos aspectos como: quiosques de atendimento, celulares, tv digital, etc..

De um modo geral, concluiu-se que o Brasil está num alto patamar de evolução no caso do governo eletrônico. O desenvolvimento brasileiro é de grande destaque no mundo. Existe um direcionamento do governo que fez com que o Brasil alcançasse êxito. Os sites governamentais não deixam nada a desejar aos países desenvolvidos, os serviços oferecidos à população estão num crescente nível de ofertas e alcance.

Porém, no caso das geotecnologias, existe um longo caminho para atingir níveis maiores de desenvolvimento. A maioria das prefeituras enfrentou e ainda enfrentam problemas de implantação de geoprocessamento que poderiam ter sido minimizados se existisse uma política desenvolvida para tal. Como visto no caso do estado de Nova lorque, que criou comitês, legislação, tendo um forte empenho de esforços e diretrizes, estão muito mais desenvolvidos e usufruindo mais desta tecnologia. A maioria das prefeituras brasileiras, exceto as capitais maiores, estão ainda no estágio de implantação do SIG para melhorar a arrecadação de impostos. As capitais que apresentam um destaque maior, como as das regiões Sul e Sudeste, além de outras como: Goiânia, Manaus, Aracaju, Maceió, Recife e algumas poucas cidades, como Santo André e Santos, conseguem usufruir os benefícios das aplicações do SIG, como por exemplo no uso policial, na saúde, educação, etc...

Vários exemplos de SIG foram citados nos municípios, o HABISP da prefeitura de São Paulo mostra bem o quanto a utilização efetiva da informação espacial pode apoiar à gestão municipal. Através do SIG, o HABISP propicia a visualização de priorização de núcleos habitacionais e de famílias que podem ser atendidas e retiradas de áreas de maior risco sócio ambiental. Além da melhoria da qualidade dos serviços públicos que ocorreram neste caso, todo um processo de transformação da administração pública pode ser sentido com mecanismos de capacitação, incentivos de participação e envolvimento dos servidores.

Ainda não se criou uma consciência geral nas administrações públicas da importância dos sistemas de informações geográficas. Está em ritmo crescente, mas 
se o governo federal ou mesmo os estados se organizassem em Comitês ou Grupos para o desenvolvimento dos projetos, rapidamente o Brasil ficaria numa posição mais competitiva nessa tecnologia no mundo, como é o caso do governo eletrônico brasileiro.

Daí a importância de iniciativas que podem centralizar esforços e favorecer 0 desenvolvimento geotecnológico brasileiro. A criação da Lei 6.666 sobre a Infraestrutura Nacional de Dados Espaciais, sinaliza uma nova visão que reconhece a importância do compartilhamento e disseminação de dados geoespaciais, entre todas as esferas de governo, entidades e cidadãos.

O geoprocessamento aplicado à gestão municipal precisa ser divulgado apresentando os objetivos de evolução e de desenvolvimento administrativo dos municípios, através de aspectos, tais como: modernização da gestão cadastral e territorial utilizados em ambiente integrado, envolvem todas as áreas do município, formam uma infra-estrutura de geoinformação unificada, com o compartilhamento, acessibilidade e transparência, abrangendo também processos de manipulação, monitoramento e fiscalização com a necessária permeabilidade setorial das bases de informações e a integração das secretarias municipais, bem como o acesso dos cidadãos.

Nessa pesquisa concluiu-se que existe uma falta grave de ação dos órgãos que poderiam conduzir o desenvolvimento brasileiro das geotecnologias. Ainda é cedo para se falar do alcance da Lei 6.666 da INDE, a maioria dos órgãos entrevistados ainda não conhece as orientações, são favoráveis, mas ainda não houve uma grande mobilização de grupos técnicos para sua implantação. Poucas reuniões ocorreram para a organização dos trabalhos da INDE, segundo Oscar Schmeiske, Coordenador do Geoprocessamento do IPPUC de Curitiba, houve no primeiro semestre de 2009, apenas 2 reuniões. O Brasil tem o desafio de enfrentar uma grande desestruturação de bases cartográficas e dados espaciais.

Nem o Ministério das Cidades e nem o IBGE atenderam a inúmeros pedidos de respostas levantados neste trabalho. Existe a constatação de que são órgãos com muitos departamentos, com excesso de funcionários e que não são articulados. No IBGE, principalmente, notou-se que um setor não conhece o trabalho de outro setor, tinham dificuldade em localizar pessoas que pudessem fornecer alguma resposta e quando foi obtido contato telefônico, este não respondeu ao questionário por email. Outros órgãos nacionais foram contatados para que se pudesse identificar a existência de alguma política nacional, programa ou controle sobre levantamentos territoriais. 
Resposta negativa para o CEGE - Comitê Executivo de Governo Eletrônico e ausência de resposta do Ministério da Defesa, Divisão de Cartografia - DICAR.

Em contrapartida, nota-se que o arcabouço jurídico nunca foi tão extenso e a favor do desenvolvimento dos municípios, desde as alterações da Constituição de 1988, do Estatuto das Cidades, e outras alterações em leis, somadas a investimentos e financiamentos federais grandes, formam um quadro novo nacional de fontes de recursos, com redes ampliadas de trocas de experiências, inclusive entre países.

No caso do desenvolvimento internacional, não foi objeto da pesquisa analisar se existiam políticas de Sistemas de Informação Geográfica, devido à dimensão do assunto, ficou restringido apenas a saber se existem mapeamentos disponíveis em sites governamentais, através dos estágios de desenvolvimento de presença, interação, transação ou transformação. Na maioria dos sites acessados, os mapeamentos estão na fase de presença e interação com ferramentas de busca. Poucas foram as cidades que desenvolveram o estágio de transação ou transformação. Porém as que apresentaram até ferramentas de software SIG, ofereceram maior disponibilização de informações do que os sites de cidades brasileiras.

Ainda no cenário internacional, destacam-se os usos futuros de SIG em desenvolvimento, como o controle de gastos públicos nos Estados Unidos e o modelo de cidade $3-\mathrm{D}$ em Londres.

Muitos municípios brasileiros que já possuem SIG implantado no ambiente interno da prefeitura afirmaram que estão em adequação para disponibilizá-los na Internet. Os que já apresentam SIG na Internet, também afirmaram que estarão aperfeiçoando mais funções para a web.

Constatou-se, então que existe uma tendência a melhoria dos produtos de geoprocessamento nos sites públicos. Outro ponto a ser destacado é que existe tanto no Brasil como no mundo uma tendência a padronização de arquivos, softwares livres e softwares com cada vez mais plataformas de uso na internet, formação de IDEs Infraestruturas de dados espaciais. Apontando para um futuro com muita integração de dados, informações e comunicação. 


\section{REFERÊNCIAS}

AVERY, T. E.; BERLIN, G. L. Fundamentals of Remote Sensing and Airphoto Interpretation. 5 ed. New Jersey: Prentice Hall. 1992.

BRASIL. Decreto no 6.666 de 27/11/2008. Disponível em: http://www.planalto.gov.br/ccivil 03/ Ato2007-2010/2008/Decreto/D6666.htm . Acesso em 05/06/2009.

BRASIL. Histórico do governo eletrônico. Disponível em: <http://www.governoeletronico.gov.br/o-gov.br/historico>. Acesso em: 12 mar. 2009.

BRASIL. Princípios. Disponível em: <http://www.governoeletronico.gov.br/ogov.br/principios>. Acesso em: 12 mar. 2009.

BRASIL. E-Ping - Padrões de Interoperabilidade. Disponível em: <http://www.governoeletronico.gov.br/o-gov.br/e-ping>. Acesso em: 12 mar. 2009.

BANUNAS, loberto Tatsch. Poder de Polícia Ambiental e o Município. Porto Alegre: Sulina, 2003.

CÂMARA, Gilberto; MONTEIRO, Antonio Miguel; FUCKS, Suzana D.; CARVALHO, Marina Sá. Analise Espacial de Dados Geográficos. Brasília, EMBRAPA, 2004. Disponível em: http://www.dpi.inpe.br/gilberto/tutoriais/analise/cap1.pdf. Acesso em 01/11/2007.

CIEG (Centro Integrado de Estudo de Geoprocessamento). O Que É Geoprocessamento. Disponível em: http://www.cieg.ufpr.br/geo.htm. Acesso em 22/07/1998.

COMISSÃO MUNDIAL DE MEIO AMBIENTE E DESENVOLVIMENTO - CMMAD. Relatório Nosso Futuro ou Relatório Brundtland. Rio de Janeiro: Editora da Fundação Getúlio Vargas, 1988.

CONFERÊNCIA URBAN AGE. Programa de Cidades da The London School of Economics and Political Science and Deutsche Bank's Alfred Herrhausen Society (Org.). Disponível em http:// www.urban-age.net/ . Acesso em 05/06/2009.

DANGERMOND, Jack. GIS Brings Better Government Transparency In: Government Technology Magazine, 01 de maio de 2009, Disponível em: https://www.govtech.com, Acesso em 27/06/2009. 
ESTATUTO DA CIDADE. Lei 10.257, de 10 de julho de 2001. Disponível em: https://www.planalto.gov.br/ccivil_03/Leis/LEIS_2001/L10257.htm. Acesso em: 05/06/2009.

FERNANDES, Sarah. Saúde Digital In: Jornal eletrônico Prima Página, Maceió. Disponível em: http://www.pnud.org.br/noticias/index.phpid01=2785. Acesso em 15/11/2007.

FUNCATE - Fundação de Ciência, Aplicações e Tecnologia Espaciais. Gestão Municipal Integrada - GMI. Disponível em: http://www.geo.funcate.org.br/prefeituras. Acesso em 03/11/2007.

GIDDENS, Anthony. Grandes entrevistas do milênio: o olhar de grandes pensadores sobre o mundo atual e suas perspectivas. São Paulo: Globo, 2008.

GOVERNO DO ESTADO DE SÃO PAULO. Salas de Atendimento. Disponível em: www.poupatempo.sp.gov.br/e_poupatempo/salas.htm. Acesso em 23 mar. 2009

HERCULANO, Selene C. A qualidade de vida e seus indicadores. In: Revista Ambiente e Sociedade, Campinas, UNICAMP/NEPAM, Ano I, nํ2, 1998, pp 77 99)

IDGNow. Disponível em: http://idgnow.uol.com.br/computacao_corporativa. Acesso em 22/10/2007.

INSPIRE - Infrastructure for Spatial Information in the European Community. Reports, disponível em: http://inspire.jrc.ec.europa.eu/ Acesso em 24/04/2009

INTERNACIONAL TELECOMMUNICATION UNION, Statistics, disponível em: http://www.itu.int/ITU-D/ict/statistics/. Acesso em 30/11/2007.

MACHADO, Reinaldo Paul Pérez. As novas tecnologias na geografia contemporânea: reflexões sobre o debate espanhol. Biblio $3 W$, Revista Bibliográfica de Geografia e Ciências Sociais, Universidade de Barcelona, Volume XIV, no 809, 15 de janeiro de 2009, disponível em: http://www.ub.es/geocrit/b3w-809.htm. Acesso em 16/10/2009.

MARINHO, Luiz. Discurso na Plenária do Plano Plurianual Participativo: São Bernardo do Campo, em 11/05/09.

MATHIEU, Márcia. Desenvolvimento Sustentável. In: UnB Agência. Disponível em: http://www.unb.br/noticias. Acesso em 20/11/2007. 
MOURA, Rosa; DIAS, Maria Luiza; DESCHAMPS, Marley Vanice; DELGADO, Paulo Roberto; RIBEIRO, Luiz César de Queiroz (organizador). Hierarquização e identificação dos espaços urbanos. Rio de Janeiro: Letra Capital: Observatório das Metrópoles, 2009

MUNICÍPIO DE GOIÂNIA. YUASA, Flávio (Coord. de geoprocessamento). Comunicação pessoal. Data: 05/06/2009.

MUNICÍPIO DE ARACAJU. CORDOVEZ, Juan Carlos Gortaire (Diretor de gestão urbana da Secretaria de Planejamento). Arquivo pessoal. Data: 05/06/2009.

MUNICÍPIO DE NATAL. Notícias. Disponível em: www.natal.rn.gov.br/. Acesso em 24/06/2009.

MUNICÍPIO DE PORTO ALEGRE. Histórico de geoprocessamento. Disponível em: www.portoalegre.rs.gov.br/planeja/spm2/12.htm. Acesso em: 22/06/2009.

MUNICÍPIO DE SÃO BERNARDO DO CAMPO. Plano Plurianual Participativo PPA. Folheto explicativo, S.B.C. Abril de 2009.

MUNICÍPIO DE SÃO PAULO. PRODAM - Processamento de Dados do Município. Disponível em: www.prodam.sp.gov.br/. Acesso em 18/03/2009.

NEWSLETTER IDE IBEROAMÉRICA - INFRAESTRUCTURA DE DATOS ESPACIALES. Volume 5, no 1, Buenos Ayres; Barcelona, 2009. Disponível em http://redgeomatica.rediris.es/Newsletter/. Acesso em 05/06/2009.

NOBRE, Carlos; BARRUNCHO, Luis. E- Government. Portugal: Grupo Edinfor. 2007. Disponível em http://www.lusiglob.edinfor.logicacmg.com/portal/docs/it-geoeg.pdf. Acesso em 02/11/2007.

OLIVEIRA, Ariovaldo Umbelino; CARLOS, Ana Fani Alessandri (Org.). Geografia das Metrópoles. São Paulo: Contexto, 2006.

ONU - Organização das Nações Unidas. United Nations e-goverment survey 2008 - From e-government to connected governance. Disponível em: $<$ http://unpan1.un.org/intradoc /groups/public/documents/ UN/UNPAN 028607.pdf> Acesso em 03 abr. 2009.

PARENTE, P. Política brasileira de Governo eletrônico in: E-government: o governo eletrônico no Brasil. Ferrer, Florência; Santos, Paula (Org.). São Paulo. Saraiva: 2004 
PORTUGAL. Cartão cidadão. 0 que é? Disponível em http.://www.cartaodecidadao.pt. Acesso em 03 de nov. 2007.

PNUD (Programa das Nações Unidas para o Desenvolvimento). Desenvolvimento Humano e IDH. Disponível em http://www.pnud.org.br/idh, Acesso em 10 de jun. 2009.

PNUMA (Programa das Nações Unidas sobre Meio Ambiente e Desenvolvimento). Disponível em http://www.onu-brasil.org.br/agenciaspnuma.php, Acesso em 25/10/2007.

SANCHEZ, Félix R. Participação Popular. In: Cadernos Metrópole. Número 10. São Paulo: Educ, 2003. pp. 141-174.

SILVA, Ardemirio de Barros. Sistemas de Informações Geo-Referenciadas.. Campinas: Editora da Unicamp, 2003.

SPINIK, Peter; BAVA, Silvio Caccia; PAULICS, Veronika. Novos contornos da gestão local: conceitos em construção. São Paulo: Polis, 2002.

RELATÓRIO DO VII PNAFM. UCP (Unidade de Coordenação do Programa). Relatorios. Disponível em: www.ucp.fazenda.gov.br/PNAFM/relatorios. Acesso em 18/06/2009.

UNIVERSIDADE DO SUL DE SANTA CATARINA. Governo Eletrônico: estratégias de elaboração, desenvolvimento e implementação de projetos. $2^{a}$ edição. Palhoça: Unisulvirtual, 2008.

UNIVERSIDADE FEDERAL DO RIO DE JANEIRO. SILVA, Jorge Xavier da (responsável pelo projeto). SAGA - Sistema de Análise Geo-Ambiental. Disponível em www.lageop.igeo.ufrj.br/sobre.php. Acesso em 10/11/2007. 


\section{ANEXOS}

\section{Decreto Federal $n^{\circ} 6.666$ de 27/11/2008:}

\section{"DECRETA:}

Art. $1^{0}$ Fica instituída, no âmbito do Poder Executivo federal, a Infra-Estrutura Nacional de Dados Espaciais - INDE, com o objetivo de:

I - promover o adequado ordenamento na geração, no armazenamento, no acesso, no compartilhamento, na disseminação e no uso dos dados geoespaciais de origem federal, estadual, distrital e municipal, em proveito do desenvolvimento do País;

Il - promover a utilização, na produção dos dados geoespaciais pelos órgãos públicos das esferas federal, estadual, distrital e municipal, dos padrões e normas homologados pela Comissão Nacional de Cartografia - CONCAR; e

III - evitar a duplicidade de ações e o desperdício de recursos na obtenção de dados geoespaciais pelos órgãos da administração pública, por meio da divulgação dos metadados relativos a esses dados disponíveis nas entidades e nos órgãos públicos das esferas federal, estadual, distrital e municipal.

$\S 1^{\circ}$ Para o atingimento dos objetivos dispostos neste artigo, será implantado o Diretório Brasileiro de Dados Geoespaciais -DBDG, que deverá ter no Portal Brasileiro de Dados Geoespaciais, denominado "Sistema de Informações Geográficas do Brasil - SIG Brasil", o portal principal para o acesso aos dados, seus metadados e serviços relacionados.

Art. $2^{0}$ Para os fins deste Decreto, entende-se por:

I- dado ou informação geoespacial: aquele que se distingue essencialmente pela componente espacial, que associa a cada entidade ou fenômeno uma localização na Terra, traduzida por sistema geodésico de referência, em dado instante ou período de tempo, podendo ser derivado, entre outras fontes, das tecnologias de levantamento, inclusive as associadas a sistemas globais de posicionamento apoiados por satélites, bem como de mapeamento ou de sensoriamento remoto;

II - metadados de informações geoespaciais: conjunto de informações descritivas sobre os dados, incluindo as características do seu levantamento, produção, qualidade e estrutura de armazenamento, essenciais para promover a sua documentação, integração e disponibilização, bem como possibilitar a sua busca e exploração; 
III-Infra-Estrutura Nacional de Dados Espaciais-INDE: conjunto integrado de tecnologias; políticas; mecanismos e procedimentos de coordenação e monitoramento; padrões e acordos, necessário para facilitar e ordenar a geração, o armazenamento, o acesso, o compartilhamento, a disseminação e o uso dos dados geoespaciais de origem federal, estadual, distrital e municipal;

IV - Diretório Brasileiro de Dados Geoespaciais - DBDG: sistema de servidores de dados, distribuídos na rede mundial de computadores, capaz de reunir eletronicamente produtores, gestores e usuários de dados geoespaciais, com vistas ao armazenamento, compartilhamento e acesso a esses dados e aos serviços relacionados; $e$

$V$ - Portal Brasileiro de Dados Geoespaciais, denominado "Sistema de Informações Geográficas do Brasil - SIG Brasil": portal que disponibilizará os recursos do DBDG para publicação ou consulta sobre a existência de dados geoespaciais, bem como para o acesso aos serviços relacionados.

$\S 1^{\circ}$ Os dados estatísticos podem, a critério do órgão produtor, ser considerados como dados geoespaciais, desde que estejam de acordo com a definição do inciso I do caput.

$\S 2^{\circ}$ Serão considerados dados geoespaciais oficiais aqueles homologados pelos órgãos competentes da administração pública federal, e que estejam em conformidade com o inciso I do caput.

Art. $3^{0}$ O compartilhamento e disseminação dos dados geoespaciais e seus metadados é obrigatório para todos os órgãos e entidades do Poder Executivo federal e voluntário para os órgãos e entidades dos Poderes Executivos estadual, distrital e municipal.

$\S 1^{\circ}$ Constituem exceção a esta obrigatoriedade as informações cujo sigilo seja imprescindível à segurança da sociedade e do Estado, nos termos do art. $5^{\circ}$, inciso XXXIII, da Constituição e da Lei $n^{\circ} 11.111$, de 5 de maio de 2005.

$\S 2^{0}$ Os dados geoespaciais disponibilizados no DBDG pelos órgãos e entidades federais, estaduais, distritais e municipais devem ser acessados, por meio do SIG Brasil, de forma livre e sem ônus para o usuário devidamente identificado, observado o disposto no $\S 1^{\circ}$.

Art. $4^{\circ}$ Os órgãos e entidades do Poder Executivo federal deverão:

I - na produção, direta ou indireta, ou na aquisição dos dados geoespaciais, obedecer aos padrões estabelecidos para a INDE e às normas relativas à Cartografia Nacional; e 
II - consultar a CONCAR antes de iniciar a execução de novos projetos para a produção de dados geoespaciais, visando a eliminar a duplicidade de esforços e recursos.

Art. $5^{\circ}$ Compete ao Instituto Brasileiro de Geografia e Estatística - IBGE, como entidade responsável pelo apoio técnico e administrativo à CONCAR:

I - construir, disponibilizar e operar o SIG Brasil, em conformidade com o plano de ação para implantação da INDE, de que trata o inciso VIII do art. $6^{\underline{0} \text {; }}$

II - exercer a função de gestor do DBDG, por meio do gerenciamento e manutenção do SIG Brasil, buscando incorporar-Ihe novas funcionalidades;

III - divulgar os procedimentos para acesso eletrônico aos repositórios de dados e seus metadados distribuídos e para utilização dos serviços correspondentes em cumprimento às diretrizes definidas pela CONCAR para o DBDG;

$I V$-observar eventuais restrições impostas à publicação e acesso aos dados geoespaciais definidas pelos órgãos produtores;

$V$ - preservar, conforme estabelecido na Lei $n^{\circ} 5.534$, de 14 novembro de 1968, o sigilo dos dados estatísticos considerados dados geoespaciais de acordo com o $\S 1^{\circ}$ do art. $2^{\circ}$; e

VI - apresentar as propostas dos recursos necessários para a implantação e manutenção da INDE.

Parágrafo único. O IBGE enviará à CONCAR, anualmente, relatório das atividades realizadas com base neste artigo.

Art. $6^{0}$ Compete à CONCAR:

I- estabelecer os procedimentos para a avaliação dos novos projetos de que trata 0 inciso II do art. $4^{\underline{0}}$;

II - homologar os padrões para a INDE e as normas para a Cartografia Nacional, nos termos do Decreto-Lei $n^{\circ} 243$, de 28 de fevereiro de 1967, e do Decreto $n^{\circ}$ 89.817, de 20 de junho de 1984;

III - definir as diretrizes para o DBDG, com o objetivo de subsidiar a ação do IBGE, nos termos do inciso III do art. $5^{\circ}$;

IV-garantir que o DBDG seja implantado e mantido em conformidade com os Padrões de Interoperabilidade de Governo Eletrônico, mantidos pela Secretaria de Logística e Tecnologia da Informação, do Ministério do Planejamento, Orçamento e Gestão; 
$V$ - promover o desenvolvimento de soluções em código aberto e de livre distribuição para atender às demandas do ambiente de servidores distribuídos em rede, utilizando o conhecimento existente em segmentos especializados da sociedade, como universidades, centros de pesquisas do País, empresas estatais ou privadas e organizações profissionais;

VI - coordenar a implantação do DBDG de acordo com o plano de ação para implantação da INDE, de que trata o inciso VIII deste artigo;

VII - acompanhar, na forma do parágrafo único do art. $5^{\underline{o}}$, as atividades desempenhadas pelo IBGE previstas no referido artigo; e

VIII - submeter ao Ministério do Planejamento, Orçamento e Gestão plano de ação para implantação da INDE, para atender ao estabelecido neste Decreto, até cento e oitenta dias após a sua publicação, contendo, entre outros, os seguintes aspectos:

a) prazo para implantação das estruturas física e virtual do DBDG e do SIG Brasil;

b) prazo para a CONCAR homologar normas para os padrões dos metadados dos dados geoespaciais;

c) prazo para os órgãos e entidades do Poder Executivo federal disponibilizarem para a CONCAR e armazenarem, no servidor do sistema de sua responsabilidade, os metadados dos dados geoespaciais de seu acervo;

d) prazo para início da divulgação dos metadados dos dados geoespaciais e da disponibilização dos serviços relacionados, pelo SIG Brasil;

e) regras para disponibilização na INDE dos metadados de novos projetos ou aquisições de dados geoespaciais; e

f) recursos financeiros necessários para a implantação da INDE, ouvido o IBGE, nos termos do inciso VI do art. 5, incluindo as necessidades do DBDG e do SIG Brasil, bem como os recursos financeiros necessários ao desenvolvimento de padrões, para divulgação da INDE, capacitação de recursos humanos e promoção de parcerias com entidades e órgãos públicos federais, estaduais, distritais e municipais.

Art. $7^{\circ}$ Caberá à Secretaria de Planejamento e Investimentos Estratégicos, do Ministério do Planejamento, Orçamento e Gestão, promover, junto aos órgãos das administrações federal, distrital, estaduais e municipais, por intermédio da CONCAR, as ações voltadas à celebração de acordos e cooperações, visando ao compartilhamento dos seus acervos de dados geoespaciais. 
Art. $8^{0}$ Este Decreto entra em vigor na data de sua publicação.

Brasília, 27 de novembro de 2008;

LUIZ INÁCIO LULA DA SILVA. In: BRASIL. Decreto no 6.666 de 27/11/2008. Disponível em: http://www.planalto.gov.br/ccivil 03/ Ato2007-2010/2008/Decreto/D6666.htm Acesso em 05/06/2009. 


\section{RESPOSTAS AOS QUESTIONÁRIOS (MODELO 01) ENVIADOS ÀS AGENCIAS ESTADUAIS DE TI}

\author{
Respostas - Questionário nº1
}

\author{
ETICE - Empresa de \\ Tecnologia da Informação do Ceará
}

1) Existe alguma iniciativa de gerenciamento de informações espaciais ou georreferenciadas no estado?

*Sim. O Estato criou um comitê de geotecnologia com representação de diversos orgãos para

definir as diretrizes e gerenciamento das informações espaciais do Estado.

Atualmenmto o

IPECE (www.ipece.ce.gov.br) que é o orgão responsável pela cartografia do Estado já disponibiliza muitas informações na Web atraves do Ceará em Mapas. *

2) Existe algum grupo de trabalho que tem a incumbência de formular normas e padronização

de sistemas de geoprocessamento para órgãos públicos ou prefeituras?

*Sim. O comitê de geotecnologia tem esta incumbência. A coordenação do comitê esta com a

Secretaria da Casa Civil com o Sr. Lincoln (lincoln@casacivil.ce.gov.br).*

3) Existem projetos de geoprocessamento no Estado?

*Os grandes projetos do Estado na área de geotecnologia são: A criação de uma nova base

cartográfica na escala de 1:25.000 nas áreas rurais e 1:5.000 nas áreas urbanas, e a integração do dados espaciais produzidos pelas diversas secretarias.

*4) O Governo Federal lançou em 27/11/08 o Decreto $n^{\circ} 6.666$ que institui a Infra-estrutura Nacional de Dados Espaciais (INDE), para um cadastro único nacional de

banco de dados geoespaciais, a ser implantado pelo IBGE/Concar, qual é a posição da Agência para este assunto?

*É intenção do comitê está em sintonia com as proposições da INDE. *

5) Existe conhecimento de municípios que tem SIG (Sistema de Informações Geográficas)

funcionando em qualquer área, (segurança, educação, saúde etc.) e quais destes municípios

que disponibilizam aplicações de SIG em site de governo-eletrônico.

${ }^{*}$ Foi desenvolvido um SIG para o municipio de Caucais, situado na região

metropolitana de

Fortaleza, com foco no turismo e cadastro urbano para fins de recolhimento de IPTU.

Maiores informações sobre esta aplicação podem ser dada pelo Sr. Clayber

Nascimento

(cleyber@ipece.ce.gov.br), Gerente de Estatística e Geografia do IPECE, que foi quem acompanhou o desenvolvimento deste aplicativo. *

6) Como acreditam que o governo eletrônico possa ser potencializado com aplicações de 
geoprocessamento?

*Disponibiliando suas base espaciais para a comunidade em geral. ${ }^{*}$

Esparamos ter contribuido de alguma forma e nos colocamos a disposição.

Att,

Sérgio Brito

ETICE - Empresa de Tecnologia da Informação do Ceará

sbrito@etice.ce.gov.br

Data da resposta: $17 / 04 / 2009$

Respostas - Questionário nº 01

SEFAZ - Goiás

1) Existe alguma iniciativa de gerenciamento de informações espaciais ou georreferenciadas no estado?

Sim. Temos uma Supervisão de Geoprocessamento.

2) Existe algum grupo de trabalho que tem a incumbência de formular normas e padronização de sistemas de geoprocessamento para órgãos públicos ou prefeituras?

Não.

3) Existem projetos de geoprocessamento no Estado?

Existem ações feitas, na Secretaria da Fazenda, na Agência de Obras Públicas, nas

Centrais Elétricas de Goiás, na Companhia de Processamento de Dados de Goiânia.

4) O Governo Federal lançou em 27/11/08 o Decreto $n^{\circ} 6.666$ que

institui a Infra-estrutura Nacional de Dados Espaciais (INDE), para um

cadastro único nacional de banco de dados geoespaciais, a ser

implantado pelo IBGE/Concar, qual é a posição da Agência para este assunto?

Não tenho conhecimento

5) Existe conhecimento de municípios que tem SIG (Sistema de Informações Geográficas) funcionando em qualquer área, (segurança, educação, saúde etc.) e quais destes municípios que disponibilizam aplicações de SIG em site de governo-eletrônico.

Goiânia

6) Como acreditam que o governo-eletrônico possa ser potencializado com aplicações de geoprocessamento?

No controle de produção, no mapeamento de imóveis, no mapeamento de instalações elétricas, na avaliação de impactos ambientais, na definição de estradas, na revitalização de matas, no desenvolvimento social.

Vanessa, respondi com as informações que eu tenho hoje.

Caso precise mais detalhes posso tentar. 
Eu sou da Superintendência de Gestão de TI, mas fiz a Especialização em Geoprocessamento patrocinado pela SEFAZ.

Este curso foi dado para nós da SEFAZ, e de outras Secretarias para fomentar o uso do geoprocessamento a uns 5 anos atrás.

Temos tido sucesso com a implantação do geoprocessamento na SEFAZ no controle da produção agrícola, principalmente de usinas de álcool, sendo que a margem de erro já é pequena.

Abraços,

Flávio din Rezende

Data da resposta: 20/04/2009

Respostas - Questionário nº 01

CIASC - Santa Catarina

1) Existe alguma iniciativa de gerenciamento de informações espaciais ou georreferenciadas no estado?

Sim. O Estado possui diversas iniciativas. Os principais orgão que utilizam geoprocessamento são:

http://www.spg.sc.gov.br/

http://www.agricultura.sc.gov.br/

http://www.epagri.rct-sc.br => http://www.epagri.rct-

sc.br/index.php?option=com_wrapper\&view=wrapper\&ltemid=62

http://www.sds.sc.gov.br/

http://www.aguas.sc.gov.br/base/sirhesc.php

http://www.fatma.sc.gov.br/

http://portal.celesc.com.br/portal/home/index.php

http://www.casan.com.br/

2) Existe algum grupo de trabalho que tem a incumbência de formular normas e padronização de sistemas de geoprocessamento para órgãos públicos ou prefeituras?

Para a esfera estadual:

http://www.spg.sc.gov.br/

- DIRETORIA DE ESTATÍSTICA E CARTOGRAFIA

Diretor de Estatística e Cartografia: Murilo Colaço

Fone: (48) 3215-1334

Assessor do Diretor: Cláudio José Mendonça

Fone: (48) 3215-1367

Gerente de Geografia e Cartografia: César Santos

Fone: (48) 3215-1307 
3) Existem projetos de geoprocessamento no Estado?

O Estado de Santa Catarina foi o pioneiro no desenvolvimento de uma política estadual de Geoprocessamento no

ano de 1994 denominado Plano Diretor de Geoprocessamento. Porém, não evolui por fatores econômicos e de decisão.

4) $O$ Governo Federal lançou em $27 / 11 / 08$ o Decreto $n^{\circ} 6.666$ que institui a Infra-estrutura Nacional de Dados Espaciais (INDE), para um cadastro único nacional de banco de dados geoespaciais, a ser implantado pelo IBGE/Concar, qual é a posição da Agência para este assunto?

O CIASC não foi envolvido neste processo.

Acredito que a estrutura de governo do item 2 esteja.

5) Existe conhecimento de municípios que tem SIG (Sistema de Informações Geográficas) funcionando em qualquer área, (segurança, educação, saúde etc.) e quais destes municípios que disponibilizam aplicações de SIG em site de governo-eletrônico.

Acredito que o município mais organizado é o município de Blumenau. Faça contato com o IPUB.

Outras iniciativas são: Florianópolis, Criciúma, São José, Palhoça, Joinville, Chapecó, e diversos municípios

do litoral localizados entre Itapema e Itajaí.

6) Como acreditam que o governo eletrônico possa ser potencializado com aplicações de geoprocessamento?

Sim. Porém, o Brasil ainda é muito desorganizado em iniciativas de Geoprocessamento.

Os esforços estão dispersos, dificultando o desenvolvimento de produtos atualizados e de boa qualidade.

Gabriel Vieira Ferrari MSc.

Coordenador de Projeto - Grupo de BI

GEDEP

CIASC

Governo do Estado de Santa Catarina

Data da resposta: 20/04/2009 
1) Existe alguma iniciativa de gerenciamento de informações espaciais ou georreferenciadas no estado?

Sim. O Governo do Estado de Mato Grosso, desde 1996 já trabalha com dados espaciais georeferenciados, executamos neste período (1996/2002) o Diagnóstico do Estado com estudos temáticos na escala cartográfica de 1:250.000. veja site: www.seplan.mt.gov.br - zoneamento;

2) Existe algum grupo de trabalho que tem a incumbência de formular normas e padronização de sistemas de geoprocessamento para órgãos públicos ou prefeituras?

Sim. No nosso site: www.cepromat.mt.gov.br - Sistema Estadual de Informação e Tecnologia da Informação - SEITI, tem todas normas, leis, decretos, resoluções, etc. a respeito das políticas de informações no ambito do Governo do Estado. Se navegar até o item 05-Grupos Temáticos, verá que foi criado um específico para informações geográficas;

3) Existem projetos de geoprocessamento no Estado?

Sim. O Governo do Estado está atuando com projetos nos diversos órgãos do Estado, especificamente: SEPLAN, SEJUSP, INDEA, SEMA, onde utilizamos as ferramentas ArcView, ArcGis Server, Geomédia, etc.

4) $O$ Governo Federal lançou em $27 / 11 / 08$ o Decreto $n^{\circ} 6.666$ que institui a Infra-estrutura Nacional de Dados Espaciais (INDE), para um cadastro único nacional de banco de dados geoespaciais, a ser implantado pelo IBGE/Concar, qual é a posição da Agência para este assunto?

O Governo do Estado é integrante (adeso) ao Grupo de Geotecnologias do Governo Federal através do REPIG (SIPAM), e do BCDAM (MMA), inclusive estivemos em Belém-PA em reunião estratégica do BCDAM definindo as ações para implementação da INDE nos Estados da Amazônia Legal.

5) Existe conhecimento de municípios que tem SIG (Sistema de Informações Geográficas) funcionando em qualquer área, (segurança, educação, saúde etc.) e quais destes municípios que disponibilizam aplicações de SIG em site de governo-eletrônico?

Sim. No Estado, por ser um estado ligado ao Agronegócio, a maioria dos municípios já atuam com dados georeferrenciados, embora de maneira precária, quem mais se destaca, mesmo assim direcionado a arrecadação de IPTU são os municípios de Cuiabá, Varzea Grande e Lucas do Rio Verde (isto no meu entendimento, visto que conheço os trabalhos de SIG dos 03 municípios)., quanto a disponibilizar dados no site de governo eletronico (no site do Governo do Estado de Mato Grosso) temos informações do Governo do Estado nos sites dos órgãos tipo SEPLAN, SEMA, etc. Existe já uma frente trabalhando no Aglomerado Urbano Cuiabá/Varzea Grande (do qual faco parte) para disponibilizar os dados espaciais das prefeituras do agomerado já nas ferramentas de código aberto conforme a INDE, visando trabalhos ligados a secretaria de segurança pública. 
6) Como acreditam que o governo eletrônico possa ser potencializado com aplicações de geoprocessamento?

O SIG-BRASIL conforme definido no Decreto 6.666 e que esta sendo Normatizado através da INDE, deve nos próximos anos centralizar os dados georeferenciados num único site, utilizando ferramentas de código aberto - já utilizadas em algumas áreas do governo federal, e nos estados da Amazonia Legal, através do BCDAM já montamos inclusive um Plano de Ação onde estamos levantamento todos os dados e informações que possam ser espacializadas para criar os metadados e criar o link no SIG-BRASIL utilizando as ferramentas Geonetwork e I3geo.

Saudações,

Giovanni Leão Ormond

Analista TI - SEPLAN/CEPROMAT

GEOPROCESSAMENTO

Data da resposta: $21 / 04 / 2009$

Respostas - Questionário nº 01

1) Existe alguma iniciativa de gerenciamento de informações espaciais ou georreferenciadas no estado?

Existiu uma tentativa de se criar um sistema cartográfico para o Estado, mas a idéia foi por água abaixo

mais por interesses políticos do que por uma falha no sistema.

Cada Instituição gerencia ao seu modo essas informações.

2) Existe algum grupo de trabalho que tem a incumbência de formular normas e padronização de sistemas de geoprocessamento para órgãos públicos ou prefeituras?

Existe a Câmara Técnica de Cartografia, formada por profissionais de diferentes órgãos do Estado. Nela são discutidas entre outras coisas, normas existentes para a área.

\section{3) Existem projetos de geoprocessamento no Estado?}

Se a pergunta é sobre regulamentação do geoprocessamento para o Estado a resposta é não.

Se a pergunta se refere a projetos na visão de analista de sistemas, a resposta é vários.

4) $O$ Governo Federal lançou em 27/11/08 o Decreto $n^{\circ} 6.666$ que institui a Infra estrutura Nacional de Dados Espaciais (INDE), para um cadastro único nacional de banco de dados geoespaciais, a ser implantado pelo IBGE/Concar, qual é a posição da Agência para este assunto?

Há participação do Estado no Concar em várias comissões. A posição do Estado é de apoio ao Concar. 
5) Existe conhecimento de municípios que tem SIG (Sistema de Informações Geográficas) funcionando em qualquer área, (segurança, educação, saúde etc.) e quais destes municípios que disponibilizam aplicações de SIG em site de governo eletrônico?

O município de Curitiba tem a sua própria área de informática e de geoprocessamento. Como não trabalhamos diretamente com os municípios, não sabemos de iniciativas na área fora a capital.

6) Como acreditam que o governo eletrônico possa ser potencializado com aplicações de geoprocessamento?

Desde a entrada da Google na área com o Earth e o Maps, muitos, que até então não davam o devido valor ao dado espacial, passaram a cogitar a sua inclusão em seus projetos.

Hoje já não passa um dia sem que algum analista nos pergunte sobre a possibilidade de incluir mapas em seu sistema. A demanda portanto já está potencializada.

O número de aplicações geo aumentará bastante a partir do momento em que o Governo passar a investir mais em equipamentos de GPS (para policiais, fiscais...), imagens de satélite de alta resolução e infra-estrutura (equipe, servidores...) para desenvolvimento na tecnologia.

Alfredo Furukawa

Cia de Informática do Paraná - CELEPAR

\section{Data da resposta: 22/04/2009}

\section{Respostas - Questionário nº1}

1) Existe alguma iniciativa de gerenciamento de informações espaciais ou georreferenciadas no estado?

Sim. O Governo do Estado do Espírito Santo em dezembro de 1999, criou o GEOBASES - Sistema Integrado de Bases Georreferenciadas do Estado do Espírito Santo na administração pública estadual por meio do decreto 4559-r de 10 de dezembro de 1999.

2) Existe algum grupo de trabalho que tem a incumbência de formular normas e padronização de sistemas de geoprocessamento para órgãos públicos ou prefeituras?

Sim. O grupo de convenentes e integrantes do GEOBASES.

3) Existem projetos de geoprocessamento no Estado?

Sim

4) O Governo Federal lançou em 27/11/08 o Decreto $n^{\circ} 6.666$ que institui a Infra-estrutura Nacional de Dados Espaciais (INDE), para um cadastro único nacional de banco de dados geoespaciais, a ser implantado pelo IBGE/Concar, qual é a posição da Agência para este assunto?

O padrão de reconhecimento e uso internacional de metadados adotado pelo GEOBASES é o Federal Geographic Data Comitee - FGDC e será adotado o Perfil de 
Metadados no padrão ISO 19115 assim que ele for finalizado e plenamente aprovado. A estruturação dos dados do GEOBASES serão equiparados aos da Infra-estrutura Nacional de Dados Espaciais - INDE.

5) Existe conhecimento de municípios que tem SIG (Sistema de Informações Geográficas) funcionando em qualquer área, (segura nça, educação, saúde etc.) e quais destes municípios que disponibilizam aplicações de SIG em site de governo eletrônico?

Existem sim. Eles ainda serão disponibilizados através do projeto GEOBASES Online que é um proeto de Governo. Todos os que fazem parte do GEOBASES Online, disponibilização algum tipo de serviço que já faz.

potencializado

6) Como acreditam que o governo-eletrônico possa ser

com aplicações de geoprocessamento?

Aqui no Estado, através do GEOBASES e com maior força após a implementação do GEOBASES Online até dezembro de 2009.

Atenciosamente,

Leandro Roberto Feitoza

Coordenador Técnico do GEOBASES

Secretaria Executiva do GEOBASES/IJSN

leandro@feitoza.com

Data da resposta: 04/05/2009

Respostas - Questionário nº 01

PROCERGS - Soluções em

Tecnologia da Informação e

Comunicações para a Administração

Pública - Rio Grande do Sul

1) Existe alguma iniciativa de gerenciamento de informações espaciais ou georreferenciadas no estado?

Sim, emdiversas unidades, tais como : Agricultura, meio ambiente, segurança, saúde, etc

2) Existe algum grupo de trabalho que tem a incumbência de formular normas e padronização de sistemas de geoprocessamento para órgãos públicos ou prefeituras?

Existe um órgão, na secretaria de Agricultura que é responsável pela Cartografia do estado

3) Existem projetos de geoprocessamento no Estado?

Sim: recentemente foi implantado um sistema para atender a sanidade animal.

4) $O$ Governo Federal lançou em $27 / 11 / 08$ o Decreto $n^{\circ} 6.666$ que institui a Infraestrutura Nacional de Dados Espaciais (INDE), para um cadastro único nacional de banco de dados geoespaciais, a ser implantado pelo IBGE/Concar, qual é a posição da Agência para este assunto? 
Não temos interação com esse projeto.

5) Existe conhecimento de municípios que tem SIG (Sistema de Informações eográficas) funcionando em qualquer área, (segurança, educação, saúde etc.) e quais destes municípios que disponibilizam aplicações de SIG em site de governo-eletrônico?

Tem diversos municípios que trabalham com SIG, com aplicações diversas

6) Como acreditam que o governo eletrônico possa ser potencializado com aplicações de geoprocessamento?

Se "onde" interessa, geoprocessamento deve estar presente.

Estamos apostando firmemente em soluções geo. De forma prática, disponibilizamos o site geolivre (www.geolivre.rs.gov.br), que "visa prover informações básicas, confiáveis e permanentes sobre o espaço geográfico do Estado além de disseminar a tecnologia de Geoprocessamento nos diversos órgãos da administração direta e indireta do Rio Grande do Sul", conforme descrição no site.

Atualmente estamos trabalhando numa proposta mais avançada, principalmente pela mudança de paradigma de foco; agora, estamos contemplando multiplas aplicações (funções de governo) e, assim, unificando procedimentos sobre um ambiente único de recursos de geopeocessamento (hardware e software)

Nelson de Jesus Soares

Divisão de Negócios

PROCERGS

Data da resposta: $05 / 05 / 2009$

Respostas - Questionário nº 01

Fundação Seade - SP

1) Existe alguma iniciativa de gerenciamento de informações espaciais ou georreferenciadas no Estado?

R: Não existe nehuma ação coordenada dos entes do Estado no sentido da formulção de ações de gerenciamento integrado tanto de informações espaciais, quanto de georreferenciamento. O que há são iniciativas de algumas secretarias e empresas na construção de seus Sistemas de Informações Geográfica, como o Signus da Sabesp, Siplam da Secretaria do Planejamento e Infocrim da Secretaria de Segurança (como houve o Janela Eletrônica da Secretaria do Meio Ambiente). Mas na coordenado, seja de informações ou bases cartográficas.

2) Existe algum grupo de trabalho que tem a incumbência de formular normas e padronização de sistemas de geoprocessamento para órgãos públicos ou prefeituras?

Houve a iniciativa em 2004 da constituição de um grupo de trabalho para estudar a possibilidade

da implantação de uma política de informações espaciais e de geoprocessamento, onde participaram vários órgão e empresas do Estado. O intento que o governo conseguiu foi o estabelecimento da Resolução Casa Civil CC011/2005, que estabeleceu as "Políticas e Diretrizes de Geoprocessamento do Estado" (veja o site do Governo essa Resolução). A pesar de sua publicação o fato é que ela são se tornou 
uma resolução nornativa e nem "lei", ou seja, sua aplicação depende da vontade dos entes envolvidos, ou seja, ela não é aplicada. A Resolução também prevê a instalação de um Grupo Gestor das Políticas de Geoprocessamento e de um instruimento técnico (um SIG do Governo) que gerenciaria a aplicação da Resolução, que nunca foram efetivados.

3) Existem projetos de geoprocessamento no Estado? omo exposto acima, não, não coordenadamente. Hoje a única iniciativa mais concreta é a implação da atualização cartográfica do Estado (áreas rurais escala 1:25.000 e urbanas 1:10.000) coordenados pela Emplasa (o IGC não se viu na condição de tal realização, aliás, está passando por uma profunda reestruturação).

4) $O$ Governo Federal lançou em 27/11/08 o Decreto $n^{\circ} 6.666$ que institui a Infra-estrutura Nacional de Dados Espaciais (INDE), para um cadastro único nacional de banco de dados geoespaciais, a ser implantado pelo IBGE/Concar, qual é a posição da Agência para este assunto?

No caso do Governo como um todo, nenhuma, mas a Emplasa tem acompanhado esse processo. De qualquer forma, por enquanto não há qualquer norma que

obrigue os entes do Estado a acompanharem as oreintações do 6.666.

5) Existe conhecimento de municípios que tem SIG (Sistema de Informações Geográficas) funcionando em qualquer área, (segurança, educação, saúde etc.) e quais destes municípios que disponibilizam aplicações de SIG em site de governo-eletrônico?

A princípio não.

Algumas informações são coletadas sobre a existência de SIGs nos municípios por conta de projetos específicos, mas não são sistematizados em bancos de dados. $\mathrm{Na}$ Pesquisa Municipal Unificada - PMU, da Fundação Seade há perguntas sobre os sistemas de informações administrativas das prefeituras do Estado (http://www.seade.gov.br/produtos/pmu/index.php), mas nenhuma específica sobre a extencia de SIG ou e-gov.

\section{6) Como acreditam que o governoeletrônico possa ser potencializado com} aplicações de geoprocessamento?

Depende muito dos serviços disponiveis nesses sistemas, mas, a princípio, todo o sistema que permita ao cidadão o acesso às informações públicas de forma pública deve ser implantado. Isso aplica-se também às informações espaciais. Ou seja, se o Estado se comprometer à produção de informações espaciais, elas devem ser públicas e disponívies gratuitamente a todo e qualquer cidadão, assim como todas as informações administrativas que sejam espacializadas, elas devem ser públicas. O reconhecimento cidadão dos territórios é uma potente ferramenta para a democratização do Estado. Isso é o que acreditamos e o que inspirou a constituição do Centro de Estudos da Metropole, um projeto CEPID da Fapesp, coordenado pelo Cebrap e que tem o Seade e o INPE como partícipes. 


\title{
RESPOSTAS AOS QUESTIONÁRIOS (MODELOS 2, 3, 4 E 5) ENVIADOS AOS ÓRGÃOS NACIONAIS
}

\author{
Questionário $n^{\circ} 02$
}

INPE - Instituto Nacional de

Pesquisas Espaciais

1. Existe algum levantamento sobre os municípios brasileiros que possuem Sistemas de Informações Geográficas - SIG, se sim, qual é o cenário nacional de desenvolvimento

nesta área? Se houver conhecimento, favor citar municípios que tem projetos relevantes

de SIG.

Vanessa, essa pergunta teria que ser feita a outros interlocutores para propiciar uma visão representativa. O INPE interage com alguns municípios, mas nós não temos um levantamento aqui sobre o assunto. Apenas sei te dizer que Santos, São Sebastião, São José dos Campos e as grandes cidades do país com certeza conduzem projetos relevantes de geotecnologias e efetivamente usam SIG. Mas como disse, o INPE não se preocupa em manter um inventário da situação.

\section{Informações}

2. No que o Instituto pode contribuir para trabalhos de Sistema de Geográficas? Mapeamentos, softwares, apoio técnico, apoio legal e normativo?

A contribuição do INPE é bastante significativa, senão preponderante, nessa área de SIG. Fomos os precursores no desenvolvimento de software para SIG no país com o SGI/SITIM nos anos 80. Depois fizemos o SPRING, que continua a ser muito usado no país e no exterior, e hoje desenvolvemos a tecnologia aberta TerraLib, que é uma biblioteca de funções para quem quiser programar e gerar seus próprios aplicativos SIG. Não temos atribuição para fazer mapeamntos, mas eles são feitos nos projetos de pesquisa de interesse do INPE. Suporte é dado a todos os softwares que produzimos. Por último contribuimos muito com cursos de PG e de curta duração para a capacitação de estudantes e do público em geral.

institui a

\section{O Governo Federal lançou em $27 / 11 / 08$ o Decreto $n^{\circ} 6.666$ que}

Infra-estrutura Nacional de Dados Espaciais (INDE), para um cadastro único nacional de

banco de dados geoespaciais, a ser implantado pelo IBGE/Concar, que resultará na criação de um portal chamado SIG Brasil, qual será a atuação do INPE neste sentido?

O INPE deverá trabalhar junto com as demais instituições para fazer com que nossos dados espaciais (imagens, dados meteorológicos, dados de desmatamento) se enquadrem na nova legislação. 
públicas com a

4. O que o Instituto considera que irá melhorar para as administrações implantação do SIG Brasil? E para os cidadãos?

A INDE prevê que os dados das instituições federais sejam distribuidos gratuitamente, sem custos para a sociedade. Este é o principal benefício.

Julio Dalge - INPE

Data da resposta: 12/05/2009

Questionário $n^{\circ} 02$

IBGE - Instituto Brasileiro de Geografia e Estatística

1. Existe algum levantamento sobre os municípios brasileiros que possuem Sistemas de Informações Geográficas - SIG, se sim, qual é o cenário nacional de desenvolvimento nesta área? Se houver conhecimento, favor citar municípios que tem projetos relevantes de SIG.

Não existe formalmente informações sobre o estado da arte em SIG nos municípios brasileiros, bem como não há uma instituição responsável por esse cadastramento. Os sistemas de informações geográficas tem evoluído a partir da disponibilização de informações cartográficas digitais, e tem como marco legal para sua produção, o decreto-lei 243 de 1967 ( e outros correlatos para a regulamentação da Cartografia Nacional), que tem a Comissão Nacional de Cartografia - CONCAR, como órgão responsável pelo Sistema Cartográfico Nacional, tendo como foco a "Cartografia Sistemática" até a escala $1 / 25000$. Os produtos cartográficos em escala maior são preocupação da CONCAR, e para isso foi constituído um Comitê para normatizar as escalas cadastrais, que são de interesse dos municípios no desenvolvimento de SIG. Apesar da falta de normatização, muito tem sido feito na produção de informações geográficas pelo municípios, com qualidade diversificada, sendo que alguns são referência em sistemas de informações geográficas ou geoespaciais, como por exemplo o de Belo Horizonte, através da PRODABEL, desde a década de 90 evoluindo até hoje. Destaca-se também os SIG de São Paulo, Rio de Janeiro, Salvador, entre outros ....

2. No que o Instituto pode contribuir para trabalhos de Sistema de Informações Geográficas? Mapeamentos, softwares, apoio técnico, apoio legal e normativo?

Desde a década de 90, o IBGE participa do desenvolvimento da Cartografia Digital Nacional, e nesse sentido procurou junto com outros atores do SCN desenvolver metodologias e especificações técnicas para atender desde os processos de aquisição da informação, convertendo o acervo cartográfico existente, modernizando métodos de produção, acompanhando o estado da arte nas tecnologias GNSS, mudando o referencial geodésico de topocêntrico para geocêntrico e outras iniciativas para melhoria da qualidade da informação geoespacial bem como dinamizar a sua disponibilização. Todo o conhecimento da instituição está a disposição da sociedade na Internet, ou através do seu programa de treinamento, ou ainda através da 
participação na CONCAR. Nesse sentido são realizados também convênios de cooperação técnica com instituições públicas, nos diversos níveis de governo.

3. O Governo Federal lançou em 27/11/08 o Decreto $n^{\circ} 6.666$ que institui a Infra-estrutura Nacional de Dados Espaciais (INDE), para um cadastro único nacional de banco de dados geoespaciais, a ser implantado pelo IBGE/Concar, que resultará na criação de um portal chamado SIG Brasil, qual é a fase atual de ações que o Instituto está realizando neste sentido?

Primeiramente cabe esclarecer a definição da INDE, segundo decreto 6.666/08 como um : conjunto integrado de tecnologias; políticas; mecanismos e procedimentos de coordenação e monitoramento; padrões e acordos, necessário para facilitar e ordenar a geração, o armazenamento, o acesso, o compartilhamento, a disseminação e o uso dos dados geoespaciais de origem federal, estadual, distrital e municipal.

O IBGE tem um papel relevante na CONCAR, atuando como o seu braço executor em diversos aspectos. Com relação a INDE, no último dia 27 de maio foi entregue à CONCAR, o plano de ação, em atendimento ao determinado no artigo 6/ VIII, que mencionada a necessidade de submeter ao MPOG num prazo de 180 dias o referido plano. O IBGE teve um papel efetivo na coordenação do plano em questão, entregando-o no prazo estabelecido. Cabe destacar que esse plano foi construído de forma participativa com várias instituições, seguindo um dos principais conceitos da INDE: fortalecimento das relações entre instituições. Com relação do SIG Brasil, estamos no momento construindo a parte do geoportal referente a metadados, geração de bases cartográficas de referência para a INDE ( bases contínuas do Brasil nas escalas 1/1000 000 e 1/250 000), seguindo as orientações do plano para 0 desenho da arquitetura do referido geoportal.

\section{O que o Instituto considera que irá melhorar para as administrações públicas com a implantação do SIG Brasil? E para os cidadãos?}

A partir da implantação da INDE, temos como perspectiva a melhoria da vida dos cidadãos em vários aspectos, e o SIG Brasil será a grande porta de acesso da sociedade aos dados e informações geográficas que se encontram disponibilizadas pelo Governo Federal, inicialmente. Nesse sentido o IBGE reforça a sua missão de "retratar o país com informações necessárias so conhecimento de sua realidade e ao exercício da cidadania". A INDE num contexto amplo, deve considerar :

- A inclusão digital e a redução da distância entre cidadãos e governo;

- Busca por maior transparência no orçamento governamental;

- Aumento de resposta do governo de forma mais ampla e eficaz;

- Demanda da sociedade por políticas públicas mais elaboradas e bem implementadas;

- Preocupação crescente com o desenvolvimento sustentável e contínuo.

Moema Augusto - IBGE

Data da resposta: 01/09/2009 


\begin{tabular}{|c|c|}
\hline Questionário $\mathrm{n}^{\circ} 03$ & Ministério das Cidades \\
\hline Não foi respondido & \\
\hline
\end{tabular}

\section{Questionário nº 04}

\section{Comitê Executivo de Governo Eletrônico - CEGE}

1 - O CEGE vem gerenciando a execução da política brasileira de Governo Eletrônico, existe alguma orientação que inclua geotecnologias no Governo Eletrônico?

Além do CEGE os recursos tecnológicos do Governo Federal são orientados pelas normativas da Secretaria de Logistítica e Tecnologia da Informação órgão com a função de gestão do Sistema de Administração dos Recursos de Informação e Informática (SISP).

Este órgão definiu em PORTARIA NORMATIVA № 5, DE 14 DE JULHO DE 2005, os padrões de interoperabilidade e-Ping como obrigatórios naquele sistema normativo. A e-Ping em suas especificações de meios de acesso considera item para informações georreferenciadas - padrões de arquivos para intercâmbio entre estações de trabalho. Mais informações em http://www.governoeletronico.gov.br/acoes-e-projetos/e-ping-padroes-deinteroperabilidade/versoes-do-documento-da-e-ping

2 - A componente espacial no Governo Eletrônico, pode potencializar diversos serviços oferecidos a cidadãos e empresas, além de otimizar processos entre governos que conseguem ter uma visão mais abrangente do território. Existe algum levantamento sobre municípios ou órgãos brasileiros que possuem Sistemas de Informações Geográficas, se sim, qual é o cenário nacional de desenvolvimento nesta área?

Realizado por parte do CEGE ou da SLTI não. Talvez a Comissão Nacional de Cartografia - CONCAR ou o IBGE, como entidade responsável pelo apoio técnico e administrativo à CONCA disponha.

3 - 0 Governo Federal lançou em 27/11/08 o Decreto $n^{\circ} 6.666$ que institui a Infra-estrutura Nacional de Dados Espaciais (INDE), para um cadastro único nacional de banco de dados geoespaciais, a ser implantado pelo IBGE/Concar, que resultará na implantação de um portal chamado SIG Brasil, qual é a opinião do CEGE a respeito?

O comitê Executivo de Governo Eletrônico infelizmente, por motivos diversos, não se reune desde 2004. Contudo, aquele fórum não tem entre suas atribuições a de avaliar sistemas de informação ou determinadas infraestruturas. Abaixo apresentamos para conhecimento as competências do CEGE: 
I - coordenar e articular a implantação de programas e projetos para a racionalização da aquisição e da utilização da infra-estrutura, dos serviços e das aplicações de tecnologia da informação e comunicações no âmbito da Administração Pública Federal; II - estabelecer as diretrizes para a formulação, pelos Ministérios, de plano anual de tecnologia da informação e comunicações; III estabelecer diretrizes e estratégias para o planejamento da oferta de serviços e de informações por meio eletrônico, pelos órgãos e entidades da Administração Pública Federal; IV - definir padrões de qualidade para as formas eletrônicas de interação; V - coordenar a implantação de mecanismos de racionalização de gastos e de apropriação de custos na aplicação de recursos em tecnologia da informação e comunicações, no âmbito da Administração Pública Federal; VI estabelecer níveis de serviço para a prestação de serviços e informações por meio eletrônico; e VII - estabelecer diretrizes e orientações e manifestar-se, para fins de proposição e revisão dos projetos de lei do Plano Plurianual, de Diretrizes Orçamentárias e do Orçamento Anual, sobre as propostas orçamentárias dos órgãos e das entidades da Administração Pública Federal, relacionados com a aplicação de recursos em investimento e custeio na área de tecnologia da informação e comunicações.

4 - O que o Comitê considera que irá melhorar no âmbito do governo eletrônico com a implantação do SIG Brasil? E para os cidadãos? Idem.

Everson Aguiar

Data da resposta 12/05/2009

Questionário $n^{\circ} 05$

Divisão de Cartografia - DICAR do Ministério da Defesa

1 - O Ministério da Defesa, vem gerenciando os levantamentos aerofotogramétricos que existem no território brasileiro, existe alguma orientação que inclua aplicação de geotecnologias nestes levantamentos?

O Ministério da Defesa apenas exerce o controle da execução dos aerolevantamentos, não entrando no mérito das especificidades técnicas da atividade.

2 - Existe algum grupo de trabalho ou Divisão que tem a incumbência de formular normas e padronização para o uso de sistemas de geoprocessamento para órgãos públicos ou prefeituras?

O Ministério da Defesa não tem um setor técnico que trate tais assuntos. 
3 - Quando uma agência de governo ou prefeitura tornam públicos os mapeamentos do território através de sítios na Internet, disponibilizando mapas e bancos de dados de informação, como o Ministério da Defesa se posiciona perante a questão da segurança das informações territoriais?

O Ministério da Defesa controla apenas os trabalhos gerados a partir de aerolevantamentos efetuados por aeronaves.

4 - Existe algum levantamento no Ministério sobre municípios ou órgãos brasileiros que possuem Sistemas de Informações Geográficas, se sim, qual é o cenário nacional de desenvolvimento nesta área? E quanto a iniciativas em outros países, existe alguma comparação sobre o desenvolvimento brasileiro e de outros países?

O Ministério da Defesa não controla tais dados.

5 - O Governo Federal lançou em 27/11/08 o Decreto $n^{\circ} 6.666$ que institui a Infra-estrutura Nacional de Dados Espaciais (INDE), para um cadastro único nacional de banco de dados geoespaciais, a ser implantado pelo IBGE/Concar, que resultará na implantação de um portal chamado SIG Brasil, qual é a opinião do Ministério da Defesa a respeito?

O Ministério da Defesa participa de todas as atividades relacionadas a Infraestrutura Nacional de Dados espaciais (INDE)por meio da sua representação na Comissão nacional de Cartografia (CONCAR), contribuindo para o aperfeiçoamento das atividades de implantação da INDE.

Sugiro visitar o sitio eletronico do Instituto Geográfico Portugues http://www.igeo.pt

JOÃO DILERMANDO CORDEIRO GONC̣ALVES JUNIOR

Capitão-de-Mar-e-Guerra

Coordenador

Divisão de Cartografia e Aerolevantamento - DICA

Departamento de Ciência e Tecnologia - DEPCT

Secretaria de Ensino, Logística, Mobilização, Ciência e Tecnologia - SELOM

Ministério da Defesa - MD

Esplanada dos Ministérios - Bloco Q - 3ํAdar - Sala 348 - 70049-900 - Brasília -

DF

Tel./Fax: (61) 3312-8536 / 3312-4261 Endereço Eletrônico:

joao.goncalves@defesa.gov.br

Data da resposta: $31 / 07 / 2009$ 


\section{RESPOSTAS AOS QUESTIONÁRIOS (MODELO 6) ENVIADOS AOS MUNICÍPIOS}

\section{Questionário $n^{\circ} 06$}

Prefeitura Municipal de Vitória - ES

1 ? Quando o projeto começou? Quanto tempo está em uso?

Começou em 1998 com implantação em 2000. Nove anos.

2 ? Quais entidades, órgãos ou secretarias envolvidas?

Inicialmente participaram as secretarias de fazenda, meio ambiente, obras, transportes, planejamento. Hoje temos o envolvimento de quase todas as secretarias da Prefeitura embora, muitas áreas destas secretarias ainda não utilizem a ferramenta em suas rotinas.

3 ? Houve parceria com empresa privada em algum momento do projeto? Não. Houve a contratação de alguns serviços tais como, modelagem e estruturação do banco de dados, desenvolvimento de aplicativo in company, etc.

4 ? Qual foi o histórico do trabalho com relação as bases cartográficas, banco de dados, softwares e equipe envolvida? Todas as bases são do GEOBASES?

Adquirimos em 1993 a primeira restituição aerofotogramétrica do município na escala 1/2000; Em 2000, fizemos uma nova restituição, apenas das informações referentes ao sistema viário, lotes e edificações; em 2007, uma nova restituição foi contratada, na escala 1/1000; acessamos a base do GEOBASES apenas quando necessitamos de informações referentes à toda a Região Metropolitana.

5 ? Qual é o objetivo principal do trabalho?

Trabalhar com uma base cartográfica corporativa atualizada que forneça suporte às ações e projetos do município.

6 ? Quais são os produtos finais gerados?

Integração com os sistemas das diversas secretarias tais como Controle Imobiliário, Controle Mobiliário, Controle Urbano, Controle de Praças, dentre outros e aplicativos desenvolvidos em plataforma Web para consulta, visualização e impressão das informações disponíveis no banco de dados corporativo.

7 ? O SIG está disponível em site governamental? Para qual categoria de usuários: cidadãos, empresas ou governo?

Sim. Possuímos duas aplicações: uma voltada para os cidadãos em geral, com acesso na página principal da Prefeitura (link GeowebVitoria) e outra disponível na Intranet que disponibiliza todas as informações da base de dados corporativa para consulta.

8 ? Dentre as fases de desenvolvimento do governo-eletrônico, o projeto de SIG pode-se enquadrar nas seguintes categorias:

Presença: apenas disponíveis mapas de um determinado tema, com ferramentas simples de navegação como zoom in, out, pan, etc; Interação: Permite ao usuário fazer buscas no mapa, dentro de um conjunto de perguntas e obter respostas on-line.

Transação: Permite ao usuário pagar on-line por uma determinada carta ou tema e fazer dowload da informação que precisa. Permite realizar 
buscas e a construção de cartas por tema.

Transformação: Permite ao usuário a construção de cartas on-line por composição de diversos temas inclusive com operações cartográficas complexas acessando várias fontes de dados de forma integrada.

Qual é a fase de desenvolvimento deste projeto?

Presença, Interação e Transação. No site encontram-se disponibilizadas a base cartográfica do município para download, versão 2000, no formato dwg e algumas informações da base, no formato shp - shapefile, versão 2008.

9 ? Qual a previsão de evolução deste projeto de SIG?

Não temos como objetivo chegar a fase de transformação para o usuário externo, pelo menos por enquanto. Internamente, isto já é uma realidade.

10 - Há participação popular? De que forma?

Sim. Através de email acessado pelo link existente no site - Fale Conosco.

Recebemos críticas, sugestões e solicitações de informações e mapas impressos.

11 ? Quais os benefícios para a população?

Acesso às informações atualizadas do município de forma mais ágil. O nosso público é composto, em sua maioria, por estudantes e empresas da área de engenharia, topografia, etc.

12 - O Governo Federal lançou em 27/11/08 o Decreto n 6.666 que institui a Infra-estrutura Nacional de Dados Espaciais (INDE), para um cadastro único nacional de banco de dados geoespaciais, a ser implantado pelo IBGE/Concar, qual é a posição deste órgão para o assunto?

A posição desta gerência é totalmente favorável. Quanto ao órgão, acredito que atualmente não haveria impedimento mas, temos observado que isto é uma decisão política e portanto, pode ser alterada de governo para governo.

Att,

Pereira

Joseanny Gomes Poltronieri

Gerente de Geoprocessamento

Secretaria de Fazenda

Tel: (27) 3382-6340 / Fax: (27) 3382-6351

Prefeitura Municipal de Vitória

Data da resposta: 12/05/2009

Questionário nº6

Prefeitura Municipal de Colatina - ES de 2007.

1- O projeto teve início em março de 2006 e término em novembro

2- $\quad$ As secretarias que estiveram diretamente ligadas ao projeto foram: Secretaria Municipal de Finanças - SEMFI, Secretaria Municipal de Desenvolvimento Urbano -SEMDUR e Secretaria Municipal de Tecnologia da 
Informação -STI

3- $\quad$ As parecerias se concretizaram com a contratação de empresas devido às necessidades na implantação do projeto. A prefeitura já trabalhava com softwares integrados da empresa E\&l Produções de Softwares Ltda em diversos setores internos e, para desenvolvimento e customização de um software de geoprocessamento, foi contratada a empresa Maplan Aerolevantamentos S.A.

4- A Prefeitura de Colatina fazia uso de uma Base Cartográfica desatualizada e não confiável. A partir da concepção de promover uma modernização administrativa, foi contratado serviços para construção de uma Base Cartográfica Digital através de aerofotogrametria.

A iniciativa de modernização e construção desta nova Base Cartográfica, estava diretamente ligada a Superintendência de Tributação, sendo assim, o software de GIS desenvolvido e customizado foi para atender o setor tributário. As plantas de quadras e o banco de dados alfa numérico dos cadastros imobiliário, mobiliário e de logradouros utilizado pela tributação, serviu como referência inicial para os trabalhos.

Nenhuma base foi cedida pelo Geobases. No mês de abril de 2009 a Prefeitura de Colatina assinou convenio com o Geobases onde a Prefeitura vai fornecer a Base Cartográfica Digital, arquivos em shapefile, ao Geobases, para integrar um projeto de construção de uma base contínua do estado do Espírito Santo na web.

Os serviços contratados e realizados foram:

a) Atualização da Base Cartográfica Digital

$>\quad$ Vôo aerofotogramétrico da área urbana e de expansão urbana do município na escala de 1: 6.000 de uma área de 125 km;

Realização de apoio terrestre ao longo da área a ser mapeada,

$>$ Confecção de ortofotocartas planimétricas em meio digital na escala de 1:2.000, de $25 \mathrm{~km}^{2}$;

Confecção de mosaico georreferenciado digital, na escala 1:5.000 abrangendo área de $100 \mathbf{~ k m}^{\mathbf{2}}$, com resolução espacial de $50 \mathrm{~cm}$;

$>$ Reambulação de campo, de $25 \mathbf{~ k m}^{2}$;

$>$ Restituição Planimétrica Digital na escala de 1:2000, de $25 \mathbf{k m}^{2}$

$>\quad$ Geração de curva de nível automática, a partir do MDT - modelo digital do terreno, com equidistância de $2 \mathrm{~m}$;

b) Atualização do Cadastro Técnico Municipal

$>$ Recadastramento de 1.650 Logradouros;

> Recadastramento Imobiliário de 27.000 unidades imobiliárias;

$>$ Elaboração de diagnóstico de 3.000 unidades mobiliárias representadas por pessoas físicas e jurídicas que exercem atividades econômicas no município; 
> Recadastramento Econômico de 2.000 unidades mobiliárias;

> Georreferenciamento dos dados Cadastrais;

$>$ Confecção da Planta de Referência Cadastral.

c) Implantação de um Sistema de Geoprocessamento

$>$ Licenciamento de Software com recursos de geoprocessamento para Cadastro Técnico Municipal;

$>$ Customização do software;

> Implantação do Aplicativo de Geoprocessamento.

$>$ Módulo de consulta ao sistema flexível para atualização e ampliação da base de dados por parte da PMC;

$>$ Treinamento dos servidores municipais.

d) Envolvimento e Capacitação da Equipe da Prefeitura Municipal de Colatina.

e) Integração do Sistema Tributário com o Sistema de Geoprocessamento, que até determinado momento funcionavam em ilhas, isto é, separados.

5 - O objetivo principal do projeto é o de criar uma ferramenta no setor público para tomada de decisões. Era preciso implementar a modernização da gestão pública e consequentemente obter resultados positivos para o munícipe.

6 - Produtos finais gerados:

\section{Cobertura Aerofotogramétrica}

- 01 (uma) coleção em mídia CD-ROM contendo as fotografias aéreas coloridas em formato TIFF ou JPG, na escala média de 1:6.000 com resolução $1.016 \mathrm{DPI}$. Fotografias identificadas com o nome ou sigla da CONTRATANTE, nome ou sigla da empresa executora, mês e ano de execução, escala média, número de faixa e número da exposição.

escala 1.24000 , plotado em papel fotográfico, e respectivo arquivo magnético em mídia CD-ROM. No foto-índice está lançada a toponímia dos principais acidentes naturais e artificiais, enquadramento e coordenadas geográficas, número das faixas e das fotos, escala, nome da CONTRATANTE e nome da empresa executora.

\section{Apoio Terrestre e Aerotriangulação}

- Esquema geral com localização dos pontos de apoio.

- Monografia dos Marcos de referência implantados.

- Relatório técnico conclusivo dos trabalhos desenvolvidos nesta 
etapa contendo relação das coordenadas UTM e altitude dos pontos de apoio suplementar.

\section{Geração das Ortofotocartas}

- 01 (um) conjunto de arquivos em CD-ROM com as ortofotocartas coloridas georreferenciadas, em escala 1:2.000, em formato GeoTIFF.

- Mosaico georreferenciado colorido em escala 1:5.000, obtido a partir das ortofotocartas digitais, entregue em arquivo digital em CD-ROM e em 02 (duas) pranchas plotadas em ploter jato de tinta, sobre papel fotográfico, no formato A-0 e com moldura, legenda e simbologia.

etapa.

- Relatório técnico conclusivo dos trabalhos desenvolvidos nesta

\section{Restituição Digital}

- 02 (duas) coleções de plotagens em papel, do mapa índice das cartas, no formato A-0 (ABNT);

- 02 (duas) coleções de CD-ROM contendo os arquivos digitais assim organizados: Restituição individualizada por áreas, na escala de 1:2.000, no formato vetorial (DWG);

- Relatório Final descritivo e analítico, da metodologia empregada e resultados obtidos em cada etapa.

\section{Geração automática de Curvas de Nível}

- 02 (duas) coleções de plotagens em papel, do ortomosaico com a superposição das curvas de nível, no formato A-0 (ABNT);

- 01 (uma) coleção de CD-ROM contendo os arquivos digitais das curvas de nível interpoladas, no formato compatível a restituição digital.

\section{Recadastramento de Logradouros}

- $\quad$ Arquivo digital contendo todos os dados coletados através do Boletim de Logradouros (BCL) incluindo as tabelas auxiliares devidamente consistidas em formato compatível com o sistema atualmente em uso na Prefeitura Municipal de Colatina;

- $\quad$ Níveis Geográficos: código, denominação e eixo dos logradouros (representando por linhas);

- Relatórios contendo as ocorrências sobre logradouros: excluídos, não localizados e com segmentos não cadastrados por motivos de inconsistência na Planta de referência Cadastral;

- Relação dos Logradouros Incluídos. 


\section{Recadastramento Imobiliário}

- $\quad$ Planta de quadra impressa com os elementos: lotes, edificações e logradouros devidamente identificados. Existindo mais de uma unidade imobiliária em um lote, identificar a numeração e desenho da edificação de todas as unidades existentes.

- Arquivo digital contendo todos os dados coletados através do Boletim de Cadastro Imobiliário (BCl), incluindo as tabelas auxiliares devidamente consistidas, em formato compatível com o sistema atualmente em uso na Prefeitura Municipal de Colatina;

- Níveis geográficos integrados a Base cartográfica contendo a identificação cadastral e limitação dos lotes cadastrais.

- Relatórios contendo as ocorrências sobre unidades imobiliárias: excluídas, incluídas, desmembradas e remembradas e não localizadas.

\section{Recadastramento Econômico}

- Arquivo digital contendo todos os dados coletados através das Fichas de Atualização Cadastral (FAC), incluindo as tabelas auxiliares devidamente consistidas, em formato compatível com o sistema atualmente em uso na Prefeitura Municipal de Colatina;

- Relatórios contendo as ocorrências sobre unidades mobiliárias: incluídas, excluídas e não localizadas.

- Relatórios contendo as inconsistências identificadas na análise dos dados referentes a unidades mobiliárias não recadastradas;

- Manual contendo procedimentos para consistência dos dados através de levantamento de campo a ser realizada pela equipe da PMC;

\section{Planta de Referência Cadastral} quadras;

- Níveis contendo a identificação cadastral e limitação das

- Relatórios contendo as ocorrências sobre quadras: incluídas, excluídas, não localizadas, remembradas e desmembradas.

\section{Georeferenciamento}

O sistema de informações geográficas é constituído por um conjunto de aplicativos que acessam o Banco de Dados Geográficos Municipal, desenvolvidos com a finalidade de gerenciar, manter e administrar dados gráficos referentes a mapas, registros alfanuméricos e imagens, georreferenciados às Entidades Espaciais que compõem o mapeamento digital do Município: os logradouros, os setores, as quadras, os lotes, as unidades imobiliárias, as unidades mobiliárias e os pontos de referência.

O sistema é executável em rede, na condição de cliente / servidor de banco de dados. O banco de dados do sistema está instalado e foi configurado pelo contratado no servidor indicado pela prefeitura, e as licenças-cliente foram instaladas nas estações de trabalho indicadas pela prefeitura. 
O sistema permite ser utilizado em modo concorrente e possuir funções para manutenção das tabelas que constituem o banco de dados geográfico, consulta gráfica ou por atributos, e, para visualização integrada de mapas vetoriais, ortofotos, imagens (fotos e documentos), e dados alfanuméricos.

O sistema contempla funções que permite coletar, processar, sistematizar, fornecer e divulgar informações visando auxiliar.

- A tomada de decisões, no âmbito municipal,

- O planejamento estratégico, urbanístico, ambiental e setorial,

- A tributação, compreendendo imposto e taxas.

\section{Integração com os Sistemas Tributário, de Atendimento ao Cidadão e Geoprocessamento}

Foram implantados aplicativos específicos com o objetivo de agilizar a fiscalização, lançamento e recebimento de tributos, bem como aperfeiçoar as relações entre o cidadão e a administração municipal, para obtenção e serviços e envio de sugestões e reclamações nas seguintes áreas:

- $\quad$ Consulta de IPTU - Aplicativo para consultar o lançamento anual do IPTU e lançamentos complementares, a partir do Cadastro Imobiliário.

- Consulta de ISS - Aplicativos para consultar o lançamento de ISS por arbitramento ou declaração, de forma integrada com Cadastro Municipal.

- Consulta a Tributos Municipais - Aplicativos para efetuar a consulta de tributos municipais de qualquer natureza que podem ser arbitrados, tais como ISS, ITBI e Taxas.

\section{Data da resposta: 12/05/2009}

\section{Questionário nº6}

\section{Prefeitura Municipal de São José dos Campos - SP}

1 - Quando o projeto começou? Quanto tempo está em uso? O projeto de geoprocessamento iniciou-se em 1997, há 12 anos.

2 - Quais entidades, órgãos ou secretarias envolvidas?

Várias secretarias, não há uma que se sobressai em SIG no município.

3 - Houve parceria com empresa privada?

Sim, no início a empresa Funcate, mas não teve continuidade, não houve uma atualização acompanhando a dinâmica da cidade e acabou sendo posto de lado. Recentemente, a partir de 2008, a empresa Imagem está fornecendo o software Arc Gis.

4 - Qual foi o histórico do trabalho com relação as bases cartográficas, banco de dados, softwares e equipe envolvida? Há mais ou menos 10 anos, vários bancos de dados se formaram em cima 
do banco do Spring, utilizando uma base inicial em escala 1:5.000.

O que ocorreu é que cada Secretaria formou seu próprio banco de dados, duplicando esforços e algumas até adquiriram programas de SIG mas que não têm interligação. Existe o SigTrafic, o SigMund, o Terraview e o Arc Gis. O trabalho do Setor de Geoprocessamento hoje em dia é unificar os bancos de dados, através do banco mais atualizado que é o Pimob do Setor de Cadastro.

Está sendo montada uma estratégia de implantação de SIG. Já existe disponível numa rede de intranet o Portal Gis que está sendo muito útil para a integração dos trabalhos. A partir de 2009, está sendo traçado um perfil de necessidade de todas as secretarias para o SIG e procurando-se criar uma sinergia para que todos colaborem com sua implantação.

O principal problema enfrentado foi a falta de continuidade do projeto de SIG nestes 12 anos e a dificuldade causada pela descentralização da informação, ou seja, cada secretaria trabalhando com seus dados. Também haviam setores que consideram seus dados como objeto de poder, criando dificuldades para o compartilhamento. Outra característica notada é que os vendedores de aplicações e soluções tecnológicas, na ânsia de vender seus produtos e serviços, fazem uma grande propaganda mas que depois de realizado o ?negócio?, abandonam seus clientes que ficam com produtos sem uso.

5 - Qual é o objetivo principal do trabalho?

Implantar em toda a Prefeitura um Sistema de Informação Geográfica completo.

6 - Quais são os produtos finais gerados?

Por enquanto, ainda não é realizada análise espacial para aplicação de políticas públicas. O geoprocessamento atualmente é utilizado apenas para consultas simples.

7 - O SIG está disponível em site governamental? Para qual categoria de usuários: cidadãos, empresas ou governo?

Sim, algumas disponibilizações, mais direcionadas para uso dos cidadãos. No site municipal há um aplicativo do Google Earth que permite realizar buscas simples, do tipo unidades de saúde, escolas, equipamentos públicos. Localizar endereços e imprimir mapas. Há também, alguns mapas disponibilizados pela secretaria de obras, loteamentos escaneados (plantas originais), um levantamento aerofotogramétrico (scaneado) disponível em duas escalas, em 1:2.000 de 1973 e outro em 1:10.000 de 1977. Um mapa em pdf de todo o sistema viário atualizado em 2008 pela Secretaria de Obras.

8 - Dentre as fases de desenvolvimento do governo-eletrônico, o projeto de SIG pode-se enquadrar nas seguintes categorias:

Presença: apenas disponíveis mapas de um determinado tema, com ferramentas simples de navegação como zoom in, out, pan, etc; Interação: Permite ao usuário fazer buscas no mapa, dentro de um conjunto de perguntas e obter respostas on-line.

Transação: Permite ao usuário pagar on -line por uma determinada carta ou tema e fazer download da informação que precisa. Permite realizar 
buscas e a construção de cartas por tema.

Transformação: Permite ao usuário a construção de cartas on-line por composição de diversos temas inclusive com operações cartográficas complexas acessando várias fontes de dados de forma integrada.

Qual é a fase de desenvolvimento deste projeto?

O projeto de SIG disponível na internet de São José dos Campos encontra-se na fase de Interação, caminhando para a fase de Transação que permite a construção de cartas por alguns temas.

9 - Qual a previsão de evolução deste projeto de SIG?

Esperamos que a integração PIMOB x PORATAL se de em aproximados 180 dias, contudo sua evolução é constante devido a dinâmica da gestão publica municipal.

10- Há participação popular? De que forma?

Os temas disponiveis para consulta no site da prefeitura, foram elencados com base em solicitações da população e visando seu melhor atendimento.

11 - Quais os benefícios para a população?

Quando estiver em amplo funcionamento melhorará a qualidade dos serviços prestados aos cidadão por fornecer um diagnóstico real da cidade, possibilitando maior direcionamento das ações do governo.

12 - O Governo Federal lançou em 27/11/08 o Decreto ํo 6.666 que institui a Infra-estrutura Nacional de Dados Espaciais (INDE), para um cadastro único nacional de banco de dados geoespaciais, a ser implantado pelo IBGE/Concar, qual é a posição deste órgão para o assunto?

Por enquanto é só uma portaria. O Ministério das Cidades está fornecendo o GeoSnic que deve estar ajudando muito os municípios que não tem uma base gráfica.

\section{1/06/2009}

Entrevista na Prefeitura em

Assessor de Geoprocessamento: Romeu Simi Neto

\section{Questionário nº6}

Prefeitura Municipal de Santos - SP

1 - Quando o projeto começou? Quanto tempo está em uso?

O projeto de geoprocessamento iniciou-se em no final de 2002. São 7 anos de desenvolvimento do projeto.

2 - Quais entidades, órgãos ou secretarias envolvidas?

Todas as secretarias estão envolvidas no processo. 


\section{3 - Houve parceria com empresa privada?}

Sim, a Funcate foi escolhida para a implantação do sistema e a Universidade Santa Cecília disponibilizou estagiários para os trabalhos de campo.

4 - Qual foi o histórico do trabalho com relação as bases cartográficas, banco de dados, softwares e equipe envolvida?

Primeiro, uma base de mapas existente em papel foi escaneada e vetorizada. Em seguida foi feita uma atualização dos dados contidos nestes mapas, com um amplo levantamento de campo para alimentar um banco de dados único, que englobou a princípio: cadastro de logradouros, setores, quadras, lotes, edificações, atividades econômicas, estabelecimentos de ensino, unidades de saúde. Foi também realizado um levantamento aerofotogramétrico com restituição para a escala 1:1.000 na área insular e 1:10.000 na área continental. Todos os dados foram cruzados e assim gerada uma confiável base gráfica e de dados para todo o município. As fotos ortorretificadas estão disponíveis no site da prefeitura permitindo que o usuário visualize também o desenho do lote, o perímetro da edificação e a foto frontal da edificação, que foi inserida junto com informações de cada lote.

Com relação ao software utilizado para o SIG, a equipe de geoprocessamento pesquisou todas os existentes no mercado e optou pela plataforma Terralib desenvolvida pelo INPE, cuja característica principal é poder ser customizada para cada Secretaria. A prefeitura conta com programadores especializados que desenvolvem módulos de geoprocessamento para cada necessidade de trabalho. Todos os computadores da prefeitura são interligados através de cabeamento de fibra ótica e sistema de banco de dados Oracle.

\section{5 - Qual é o objetivo principal do trabalho?}

Ter um completo gerenciamento de todo o território do município, permitindo o direcionamento de políticas públicas transformadas em ações concretas que melhorem a qualidade de vida da população.

6 - Quais são os produtos finais gerados?

Exemplos diversos podem ser citados: a Secretaria da Educação fornecia vale transporte (passe escolar) para os estudantes das escolas municipais que tinham de se deslocar mais de $2 \mathrm{~km}$ para chegar à escola. Através do SIG identificou-se cruzando a localização da escola com o endereço dos alunos, aqueles que realmente precisavam do benefício. Atualmente reduziu-se de 2.000 passes escolares por mês para cerca de 300 passes por mês. Com essa redução de custos, pode-se incluir também os estudantes que moram num raio de 1,7 ou $1,8 \mathrm{~km}$ da escola.

Na secretaria da saúde, por exemplo, existem pessoas que devido a tratamentos médicos precisam de uma dose diária de morfina. Ocorre que a morfina causa dependência química e muitos usuários pegavam a dose diária em um posto de saúde de manhã e uma segunda dose em outro posto à tarde. Cruzando informações da Secretaria da Saúde com os dados do usuário, identificou-se as pessoas que precisavam de ajuda para combater a dependência 
química.

Outro caso, o combate à dengue, técnicos de campo, quando identificam foco do mosquito transmissor, enviam através de celulares $3 \mathrm{G}$, a localização do imóvel e em tempo real a Secretaria responsável é informada e pode direcionar agentes de combate naquela área, dimensionar equipes, etc.

A Secretaria de Meio Ambiente tem todas as árvore do município georreferenciadas e no Jardim Botânico todas as espécies cadastradas.

O bairro Marapé é muito sujeito à inundações, lá estão instalados barômetros e pluviômetros que avisam com antecedência de 3 horas identificando em mapa a área que vai ser alagada e assim a defesa civil consegue tomar providências mais rapidamente.

Outro ponto a ser destacado é a segurança das informações. Um funcionário que tem acesso a dados confidenciais, por exemplo lista dos pacientes com AIDS, pode acessar o sistema através de senhas sem que todos tenham acesso a estes dados. Da mesma forma, uma secretaria só tem acesso a informações de seu interesse. O sistema também permite identificar o funcionário que fez mal uso da informação, tentando apagar algum débito de IPTU, por exemplo.

7 - O SIG está disponível em site governamental? Para qual categoria de usuários: cidadãos, empresas ou governo?

Sim, principalmente para cidadãos.

8 - Dentre as fases de desenvolvimento do governo-eletrônico, o projeto de SIG pode-se enquadrar nas seguintes categorias:

Presença: apenas disponíveis mapas de um determinado tema, com ferramentas simples de navegação como zoom in, out, pan, etc;

Interação: Permite ao usuário fazer buscas no mapa, dentro de um conjunto de perguntas e obter respostas on-line.

Transação: Permite ao usuário pagar on-line por uma determinada carta ou tema e fazer download da informação que precisa. Permite realizar buscas e a construção de cartas por tema.

Transformação: Permite ao usuário a construção de cartas on-line por composição de diversos temas inclusive com operações cartográficas complexas acessando várias fontes de dados de forma integrada.

Qual é a fase de desenvolvimento deste projeto?

Por enquanto Santos encontra-se na fase de Transação porque permite fazer download dos mapas pela Internet e buscas sobre alguns temas, como localização de equipamentos de saúde e educação.

9 - Qual a previsão de evolução deste projeto de SIG?

Provavelmente, até o final de 2009, estarão disponíveis na Internet 
diversas outras operações de composição de mapas de vários temas de interesses e assim terá atingido a fase de Transformação.

10- Há participação popular? De que forma?

Sim, na revisão do Plano Diretor, houve audiências públicas para discussão dos temas.

11 - Quais os benefícios para a população?

A gestão publica consegue através da análise espacial propiciada pelo Sistema de Informação Geográfica, identificar áreas com as mais variadas demandas, ter uma leitura mais precisa da cidade e direcionar ações mais rapidamente. E sem dúvida o fator determinante de sucesso do SIG em

Santos é o forte comprometimento do Prefeito João Paulo Papa, que através de uma visão técnica, que deu o apoio fundamental na implantação de todas as fases do projeto.

12 - O Governo Federal lançou em 27/11/08 o Decreto n 6.666 que institui a Infra-estrutura Nacional de Dados Espaciais (INDE), para um cadastro único nacional de banco de dados geoespaciais, a ser implantado pelo IBGE/Concar, qual é a posição deste órgão para o assunto?

Entrevista realizada no dia 02/06/2009 na Secretaria Municipal de Planejamento de Santos - Seplan
Coordenador de Gerenciamento e Integração de Programas Urbanos Eduardo Kimoto Hosokawa

\section{Questionário $n^{\circ} 06$}

\section{Prefeitura Municipal de Santo André -} SP

1 - Quando o projeto começou? Quanto tempo está em uso? A base Cartográfica Georeferenciada foi contratada em 90

2 - Quais entidades, órgãos ou secretarias envolvidas?

Atualmente 25 áreas atualizando seus dados, e o projeto de SIG organizado pela Informática a partir de 2004, que possibilitou o direcionamento para as secretarias e funcionários usarem de forma mais rotineira. Antes o uso era disperso. Hoje toda a prefeitura usa um único banco de dados e única base gráfica. A grande sacada foi ter a atualização através da web, todas as informações que chegam de campo diariamente são atualizadas e os funcionários das praças de atendimento passam informações on line ao cidadão através da Internet. Esta retroalimentação do sistema, gerou uma dinâmica de comprometimento dos funcionários que utilizam o SIG propiciando diversos tipos de análise espacial. 
4 - Qual foi o histórico do trabalho com relação as bases cartográficas, banco de dados, softwares e equipe envolvida?

Atualmente o banco de dados é Oracle e Softwares da família Geomedia como interface, sendo o Geomedia Web Map e o Geomedia Pro.

5 - Qual é o objetivo principal do trabalho?

Socializar a informação e publicar via Web para Praça de atendimento ao Publico agilizar os processos.

6 - Quais são os produtos finais gerados?

Planejamento, projetos, analises espaciais, mapas temáticos e outros

7 - O SIG está disponível em site governamental? Para qual categoria de usuários: cidadãos, empresas ou governo?

Estamos Modernizando nosso site para melhor atender os Munícipes e possibilitar mais serviços via Web. No momento a prefeitura conta com 2 analistas de sistema desenvolvendo uma maior disponibilização de SIG na Internet. Em breve o site municipal deverá ter mapas, imagens de satélite, etc.

8 - Dentre as fases de desenvolvimento do governo-eletrônico, o projeto de SIG pode-se enquadrar nas seguintes categorias:

Presença: apenas disponíveis mapas de um determinado tema, com ferramentas simples de navegação como zoom in, out, pan, etc; Interação: Permite ao usuário fazer buscas no mapa, dentro de um conjunto de perguntas e obter respostas on-line.

Transação: Permite ao usuário pagar on-line por uma determinada carta ou tema e fazer download da informação que precisa. Permite realizar buscas e a construção de cartas por tema.

Transformação: Permite ao usuário a construção de cartas on-line por composição de diversos temas inclusive com operações cartográficas complexas acessando várias fontes de dados de forma integrada.

Qual é a fase de desenvolvimento deste projeto?

Por enquanto somente consultas na GeoWeb de quadras fiscais. Em breve o município terá diversos produtos.

9 - Qual a previsão de evolução deste projeto de SIG?

Estamos atualizando e modernizando constantemente.

10- Há participação popular? De que forma?

A população é quem direciona a demanda, com suas solicitações.

11 - Quais os benefícios para a população?

Agilidade no atendimento.

12 - O Governo Federal lançou em 27/11/08 o Decreto no 6.666 que institui a Infra-estrutura Nacional de Dados Espaciais (INDE), para um 
cadastro único nacional de banco de dados geoespaciais, a ser

implantado pelo IBGE/Concar, qual é a posição deste órgão para o

assunto?

Nossa base esta em UTM SAD69 banco de dados modelado OPEN GIS segue um padrão que trabalho com vários Softwares de Gis inclusive Software livre Terra Lib.

Entrevista na Prefeitura em 08/06/2009

Coordenadora de Geoprocessamento: Sandra Maria Achiles Moreira

\section{Questionário nº6}

\section{Prefeitura Municipal de São Paulo - SP}

1) Quando o projeto começou? Quanto tempo está em uso?

Desde o final dos anos 80 já se tem iniciativas de criação de bancos de dados e cartografia digital, mas se analisarmos o contexto da época, já em 1978 (isso mesmo) foi criado o sistema Geolog, em mainframe, para manipulação de dados cartográficos e cadastrais. Talvez tenha sido uma experiência pioneira no mundo.

Várias formas de uso tem sido pensadas e realizadas nesses anos. Cada secretaria avançou em suas aplicações de formas diversas.

2 ) Quais entidades, órgãos ou secretarias envolvidas?

Principalmente são as secretarias: Planejamento, Meio Ambiente, Finanças, Habitação, Saúde, mas as outras também realizam projetos. Além das secretarias, participa também a Prodam (Cia. de Tecnologia de Informação).

3 ? Houve parceria com empresa privada?

Tivemos contratações de serviços, seja de consultoria, seja de execução. Geralmente são contratadas empresas privadas para todo tipo de serviço.

4 ? Qual foi o histórico do trabalho com relação as bases cartográficas, banco de dados, softwares e equipe envolvida?

base cartográfica:

A base analógica inicial foi o mapeamento 1:10.000 (sist. cartogr. metropolitano) que foi convertida no Mapa Oficial da Cidade (MOC). Essa base digitalizada gerou o Geolog, que foi atualizado das mais diversas formas, gerando uma base mista. Em 2004 foi realizado um voo e restituição e ortofotos 1:1.000. Essa base chamada Mapa Digital da Cidade (MDC) está armazenada em um servidor na Prodam e gerenciada por Oracle Spatial. 
bancos de dados:

Todos os envolvidos produzem e atualizam BDs, mas ainda não há uma centralização ou modelagem geral disso.

software:

Vários SW são utilizados, sendo os principais desktop: Maptitude, Mapinfo, Autodesk GIS, Terraview, Spring, Geomedia, além calro de Access, Excel, SPSS e outros não necessariamente geográficos.

equipe:

Temos usuários de todos os perfis: dos mais especialistas em desenvolvimento e programação até os técnicos que apenas usam a ferramenta pra seu trabalho rotineiro.

\section{5 ? Qual é o objetivo principal do trabalho?}

Creio que seja a integração das bases de dados e a disponibilização da informação ao cidadão, bem como para a tomada de decisão do executivo em políticas públicas.

\section{6 ? Quais são os produtos finais gerados?}

Análises temáticas, dados tabulados, sistemas interativos, publicações, entre outros.

7 ? O SIG está disponível em site governamental? Para qual categoria de usuários: cidadãos, empresas ou governo?

Temos o "Infolocal" disponível na web para todos os usuários.

Temos o "MDC" e o "GeoSP" na intranet para os membros da administração.

8 ? Dentre as fases de desenvolvimento do governo-eletrônico, o projeto de SIG pode-se enquadrar nas seguintes categorias:

Presença: apenas disponíveis mapas de um determinado tema, com ferramentas simples de navegação como zoom in, out, pan, etc; Interação: Permite ao usuário fazer buscas no mapa, dentro de um conjunto de perguntas e obter respostas on-line.

Transação: Permite ao usuário pagar on -line por uma determinada carta ou tema e fazer dowload da informação que precisa. Permite realizar buscas e a construção de cartas por tema.

Transformação: Permite ao usuário a construção de cartas on-line por composição de diversos temas inclusive com operações cartográficas complexas acessando várias fontes de dados de forma integrada.

Qual é a fase de desenvolvimento deste projeto?

Temos as quatro fases ocorrendo concomitantemente:

a) Presença para as publicações lançadas no site da Sempla e SVMA, por exemplo, "Município em Mapas" e outras em http://sempla.prefeitura.sp.gov.brl, e "Atlas Ambiental" em http://atlasambiental.prefeitura.sp.gov.br/ 
b) Interação com o "Infolocal" em http://infolocal.prefeitura.sp.gov.br/

c) Transação com os arquivos publicados em formato PDF, sem custo.

d) Transformação ainda que no ambiente de intranet, utilizando o banco de dados MDC em Oracle Spatial através de softwares diversos.

9- Qual a previsão de evolução deste projeto de SIG?

1. Evoluir na integração dos dados, bem como da definição clara das atribuições de cada setor da prefeitura.

2. Tornar públicas as informações produzidas com acesso via web.

10- Há participação popular? De que forma?

O cidadão participa como usuário de forma geral, mas há também audiências públicas para formulação das metas de governo.

11 - Quais os benefícios para a população?

Informação disponível e atualizada em tempo real.

Transparência na gestão pública.

12 - O Governo Federal lançou em 27/11/08 o Decreto no 6.666 que institui a Infra-estrutura Nacional de Dados Espaciais (INDE), para um cadastro único nacional de banco de dados geoespaciais, a ser implantado pelo IBGE/Concar, qual é a posição deste órgão para o assunto?

Embora não conheçamos detalhes, somos plenamente favoráveis a definição de padrões para publicação eletrônica de dados espaciais. disposição.

Espero ter respondido de acordo com sua necessidade. Estamos à

Abraços

Silvio Silvio César Lima Ribeiro 


\section{Questionário nº6}

\section{Prefeitura Municipal de Belo Horizonte} - MG

\section{1 - Quando o projeto começou? Quanto tempo está em uso?}

O inicio se deu em 1992 quando a Prefeitura interessada em automatizar a cartografia existente, teve conhecimento sobre a tecnologia SIG e percebeu que poderia fazer algo a mais do que simplesmente plotar mapas.

Pode-se dizer que foi pioneira no Brasil e através de licitação internacional adquiriu um software de geoprocessamento. O software escolhido foi o francês APIC que veio com uma série de dificuldades, algumas típicas da época tecnológica dos anos 90, como os equipamentos caros, rede precária, ausência de mão de obra especializada e outros problemas como a linguagem do programa toda em francês, suporte técnico insuficiente e dificuldade de adaptação na dinâmica administrativa da cidade. OK

\section{2 - Quais entidades, órgãos ou secretarias envolvidas?}

Em termos de tecnologia de geo, $80 \%$ da PBH já tem alguma coisa em desktop e dados georeferenciados, mas ainda utilizam da Prodabel para uma série de atividades relacionadas ao geo. Em termos de autonomia completa, diria que pouco mais de seis secretarias, considerando a produção de dados geográficos, utilizaão de plataforma de geo e desenvolvimento de aplicações.

3 - Houve parceria com empresa privada? Não. Tivemos aquisição de equipamentos e sws.

4 - Qual foi o histórico do trabalho com relação as bases cartográficas, banco de dados, softwares e equipe envolvida?

Por volta dos final dos anos 90 , com o avanço dos micro computadores, das redes e dos softwares, optou-se por "aposentar" o APIC e migrar para o ORACLE que possibilita maior interface com outros programas e a partir daí a prefeitura usa o Geomedia Profissional e o Mapinfo.

Diversas áreas da prefeitura, como a Educação, a Saúde e a Limpeza Urbana usam o Mapinfo e lidam com uma base de dados menor, mas todas usam o banco integrado em Oracle.

Foi contratado recentemente um novo vôo aerofotogramétrico que atualizará toda a base cartográfica da cidade.

A Prodabel que é uma empresa de tecnologia da informação e comunicação gerencia - MUBE, mapa urbano de Belo Horizonte e a prefeitura gerencia o cadastro técnico municipal. A prefeitura conta também com programadores que desenvolvem aplicativos de SIG, mas de forma muito pontual e específica para o usuário que solicita. O que falta para o SIG de BH estar mais desenvolvido é a disseminação dos conceitos através dos funcionários e uma conscientização dos seus benefícios desde as rotinas diárias até as análises espaciais que são necessárias para direcionar as ações do governo. É "MUB" e não "MUBE". Não é a PBH que gerencia o Cadastro Técnico, é a Prodabel tbm e a PBH utiliza o Cadastro e o MUB para compatibilizar dados, extrair informações, sustentar seus projetos e programas com estas informações, aí produz as suas informações temáticas (de cada negócio específicamente) e nos repassa tbm. Sendo assim a Prodabel armazena além do MUB e metodologias do CTM, todas as informações produzidas pela PBH. O CTM se baseia num conjunto de metodologias espcífico para garantir a qualidade e precisão da informação cadastral. Isto com certeza teve um peso significativo na estruturação 
do geo, que assim não nasceu solto e sim baseado numa série de conceitos em relação ao território e em relação à cidade. Sem o CTM o geo teria demorado mais tempo para ser implementado.

5 - Qual é o objetivo principal do trabalho? Mamutenção e disponibilização da base geográfica de $\mathrm{BH}$, para acompanhamento da dinâmica da cidade e sustentação das tomadas de decisão e das políticas urbanas.

6 - Quais são os produtos finais gerados? Mapas temáticos, base cartográfica digital, fotos aéreas (de satélite, aerofotogramétricas), cartas imagens, croquis de localização, relatórios estatísticos, dados georreferencados, aplicações de análise espacial, etc.

7 - O SIG está disponível em site governamental? Não para o mundo, apenas na intranet. Para qual categoria de usuários: cidadãos, empresas ou governo? Todos.

8 - Dentre as fases de desenvolvimento do governo-eletrônico, o projeto de SIG podese enquadrar nas seguintes categorias:

Presença: apenas disponíveis mapas de um determinado tema, com ferramentas simples de navegação como zoom in, out, pan, etc;

Interação: Permite ao usuário fazer buscas no mapa, dentro de um conjunto de perguntas e obter respostas on-line.

Transação: Permite ao usuário pagar on -line por uma determinada carta ou tema e fazer dowload da informação que precisa. Permite realizar buscas e a construção de cartas por tema.

Transformação: Permite ao usuário a construção de cartas on-line por composição de diversos temas inclusive com operações cartográficas complexas acessando várias fontes de dados de forma integrada.

A idéia é agregar todas as funcionalidades acima na internet.

Qual é a fase de desenvolvimento deste projeto? Em análise pela alta administração.

9 - Qual a previsão de evolução deste projeto de SIG? Até o final deste ano.

10 - Há participação popular? De que forma? Não, por enquanto.

11 - Quais os benefícios para a população? Acesso às informações geográficas, pesquisa de dados, conhecimento da cidade e colaboração com informações específicas e de interesses diversos tbm.

12 - O Governo Federal lançou em 27/11/08 o Decreto № 6.666 que institui a Infra estrutura Nacional de Dados Espaciais (INDE), para um cadastro único nacional de banco de dados geoespaciais, a ser implantado pelo IBGE/Concar, qual é a posição deste órgão para o assunto? Ainda não estudamos a fundo esta metodologia (podemos chamar assim?) mas estamos nos preparando. Primeiro estamos estruturando esta disponibilização internamente na $\mathrm{PBH}$. A idéia do BD geográfico vai nesta linha, definição de modelos de dados geográficos ou espaciais e tecnologia que suporte a disponilização clara e tranparente destas informações para o mundo (não só do MUB mas dos temas tbm), com as aplicações para web que devemos disponilizar até o final de 2009.

Entrevista na Prefeitura em 17/06/2009 por telefone.

Thelma Palhares - Prodabel -
Processamento de Dados de Belo
Horizonte




\section{Questionário nº6}

Prefeitura Municipal do Rio de Janeiro -

RJ

Geo com várias ferramentas on-line, bem desenvolvido. Envolve todas as secretarias.

Executado pelo Instituto Municipal de Urbanismo Pereira Passos. Acesso pelo portal municipal ou www.armazemdedados.rio.ri.gov.br

1 ? Quando o projeto começou? Quanto tempo está em uso?

Início da década de 1990, está em uso desde então.

2 ? Quais entidades, órgãos ou secretarias envolvidas?

Em diferentes níveis e estágios, praticamente toda a PCRJ. Através de consulta aos aplicativos em nosso sítio, todos.

3 ? Houve parceria com empresa privada?

Não.

4 ? Qual foi o histórico do trabalho com relação as bases cartográficas, banco de dados, softwares e equipe envolvida?

impossível neste prazo, estarei no Geo Brasil em julho, se quiser podemos conversar lá.

5 ? Qual é o objetivo principal do trabalho?

disseminar informações georreferenciadas e apoiar os diversos sistemas corporativos da PCRJ.

6 ? Quais são os produtos finais gerados?

principalmente base de dados geográficos em ambiente corporativo e aplicativos SIG web e desktop.

7 ? O SIG está disponível em site governamental? Para qual categoria de usuários: cidadãos, empresas ou governo?

sim, http://portalgeo.rio.rj.gov.br, aberto.

8 ? Dentre as fases de desenvolvimento do governo-eletrônico, o projeto de SIG pode-se enquadrar nas seguintes categorias:

Presença: apenas disponíveis mapas de um determinado tema, com ferramentas simples de navegação como zoom in, out, pan, etc; Interação: Permite ao usuário fazer buscas no mapa, dentro de um conjunto de perguntas e obter respostas on-line.

Transação: Permite ao usuário pagar on -line por uma determinada carta ou tema e fazer dowload da informação que precisa. Permite realizar buscas e a construção de cartas por tema.

Transformação: Permite ao usuário a construção de cartas on-line por composição de diversos temas inclusive com operações cartográficas complexas acessando várias fontes de dados de forma integrada.

Temos nos vários níveis, mas não cobramos pela informação disponível para download. 
Qual é a fase de desenvolvimento deste projeto?

o projeto sofre desenvolvimento constante.

9 ? Qual a previsão de evolução deste projeto de SIG?

atualmente o foco é a integração direta entre os sistemas dos diversos

órgãos e os sistemas de geoprocessamento.

10- Há participação popular? De que forma?

Não diretamente. Existe no nosso instituto o Conselho de Informações

Estratégicas, formado por representante de diversas entidades, externas à

PCRJ, principalmente acadêmicas e de pesquisa, que discutem e orientam as nossas atividades em linhas gerais.

11 ? Quais os benefícios para a população?

12 - O Governo Federal lançou em 27/11/08 o Decreto n 6.666 que institui a Infra-estrutura Nacional de Dados Espaciais (INDE), para um cadastro único nacional de banco de dados geoespaciais, a ser implantado pelo IBGE/Concar, qual é a posição deste órgão para o assunto?

Não temos uma posição institucional até o momento.

Entrevista na Prefeitura em 18/06/2009 por telefone, e_mail em 22/06/2009.

Luiz Roberto Arueira da Silva
Instituto Municipal de Urbanismo Pereira
Passos
Diretoria de Informações da Cidade
Gerência de Geoprocessamento

Prefeitura Municipal de Recife - PE

\section{Questionário nº6}

1 - Quando o projeto começou? Quanto tempo está em uso?

R . Em 2005 com a aprovação do recurso no PNAFM. Está em uso desde 2008, mas o BD espacial só estará em sua versão final este ano. Houve várias atualizações em nossa cartografia, pois a ultima vez que atualizamos foi em 2002.

2 - Quais entidades, órgãos ou secretarias envolvidas?

R- Secretarias de Finanças e Planejamento são os principais usuários. Seguem as demais secretarias com os níveis de informação:

Secretaria de Saneamento - Saneamento

Secretaria de Educação - Escolas e Creches

Secretaria de Saúde - Postos de saúde, hospitais, clínicas ....

EMLURB ( Empresa de Manutenção e Limpeza) - Coleta de lixo e consertos de vias públicas 
URB ( Empresa de Urbanização ) - Projetos viários

\section{3 - Houve parceria com empresa privada?}

Não houve parceria. Estamos estudando essa alternativa, várias empresas estão com interesse.

4 - Qual foi o histórico do trabalho com relação as bases cartográficas, banco de dados, softwares e equipe envolvida?

$\mathrm{R}$ - Projeto foi dividido em 3 ( Três produtos ) :

1 - Atualização da Base Cartográfica - Tecnologia usada foi fotogrametria. Vôo realizado em 2007. Restituição finalizada no final de 2008.

2 - Aquisição de uma plataforma de software para implementação de um SIG. Licitação em 2007 e utilização dos produtos em 2008

3 - Sistema na WEB para atualização dos níveis de arruamento, quadras viárias, lotes, projetos e zoneamentos - 2007 finalização prevista em agosto 2009.

5 - Qual é o objetivo principal do trabalho?

R - Dotar a prefeitura do Recife de um SIG corporativo com o intuito de agilizar e otimizar as decisões com base na geografia da nossa cidade

6 - Quais são os produtos finais gerados?

7 - O SIG está disponível em site governamental? Para qual categoria de usuários: cidadãos, empresas ou governo?

$\mathrm{R}$ - Sim. Na nossa intranet. Em agosto deveremos lançar um aplicativo para os cidadãos.

8 - Dentre as fases de desenvolvimento do governo-eletrônico, o projeto de SIG podese enquadrar nas seguintes categorias:

Presença: apenas disponíveis mapas de um determinado tema, com ferramentas simples de navegação como zoom in, out, pan, etc;

Interação: Permite ao usuário fazer buscas no mapa, dentro de um conjunto de perguntas e obter respostas on-line.

Transação: Permite ao usuário pagar on-line por uma determinada carta ou tema e fazer dowload da informação que precisa. Permite realizar buscas e a construção de cartas por tema.

Transformação: Permite ao usuário a construção de cartas on-line por composição de diversos temas inclusive com operações cartográficas complexas acessando várias fontes de dados de forma integrada.

Qual é a fase de desenvolvimento deste projeto?

Interação

9 - Qual a previsão de evolução deste projeto de SIG?

R- Atualmente estamos planejando a interação com as plataformas abertas utilizando os padrões WMS e com o Google. Pretendemos também evoluir, implementando o 
visão geográfica, nos sistemas de fiscalização urbana e ambiental.

10 - Há participação popular? De que forma?

Não, mas existe um estudo de incorporar o SIG no orçamento participativo. Hoje temos mapeadas as intervenções realizadas.

11 - Quais os benefícios para a população?

$r$ - As intervenções são analisadas com mais senso social, pois conseguimos visualizar até o ambiente geográfico de determinada população, não se restringindo as divisões legais ( Bairros, Distritos e ...)

12 - O Governo Federal lançou em 27/11/08 o Decreto o 6.666 que institui a Infraestrutura Nacional de Dados Espaciais (INDE), para um cadastro único nacional de banco de dados geoespaciais, a ser implantado pelo IBGE/Concar, qual é a posição deste órgão para o assunto?

Entrevista na Prefeitura em 16/06/2009 por telefone, aguardando e_mail.

Tarcísio Neves - Diretoria de Informação da Secretaria de Planejamento

\section{Questionário $n^{\circ} 06$}

Prefeitura Municipal de Aracaju - SE

Oi Vanessa:

Sou Diretor de Gestão Urbana da Secretaria Municipal de Planejamento de Aracaju, coordenei de 2001 a 2007 e ainda gerencio o processo de implantação de Geoprocessamento na Prefeitura de Aracaju.

Estou enviando em anexo um documento que relata nossa experiência em GEO. O documento foi preparado para uma empresa que solicitou essas informações, mas acho que atende sua necessidade também.

mail

Hoje estou saindo de férias, mas pode canalizar qualquer pedido por meu e-

Estaremos no GEO Summit (antigo Geobrasil) em julho em São Paulo, se for de seu interesse poderíamos nos encontrar ai e conversar mais.

Atenciosamente,

Juan Carlos Gortaire Cordovez

Diretor de Gestão Urbana

Secretaria Municipal de Planejamento de Aracaju

juan.cordovez@aracaju.se.gov.br

Documento Anexo: 
O processo de implantação de Geoprocessamento na administração municipal de Aracaju se iniciou efetivamente no ano 2001, mas teve como antecedentes a participação de quatro funcionários em seminários da área e a tentativa de implantação por parte de uma empresa contratada de um SIG para auxiliar o licenciamento de obras, ainda no final da década de 90.

A experiência, mal sucedida, teve o acompanhamento desses quatro técnicos que, no limite de suas atribuições, observaram as deficiências do processo Dentre os principais equívocos apontados foi a de tentar impor uma nova tecnologia sem ter criado antes uma cultura geográfica e um convencimento pleno das autoridades e servidores sobre as vantagens que o GEO poderia trazer à gestão urbana. A forma de contratação também foi criticada, porque não previa transferência de tecnologia e obrigava o Município a renovar licenças periodicamente para poder continuar usando o sistema. Criava-se assim uma relação de dependência tecnológica total a um alto custo econômico, bem no estilo da locação de sistemas de gestão infelizmente ainda hoje praticada.

Mas o principal erro foi o de iniciar o processo pela implantação do SIG quando à época o Município não contava com dados e informações georreferenciadas suficientes e adequados para alimentar esse sistema, nem com usuários convencidos e preparados para utilizá-lo.

Pode-se afirmar que o único produto destacável dessa tentativa abortada foi a de ter deixado ensinamentos sobre "como não fazer as coisas" e uma semente GEO que acabaria, nos anos seguintes, germinando e produzindo importantes frutos.

Em março de 2001, inicia-se na Secretaria Municipal de Planejamento um processo formal de implantação de GEO ao se criar o cargo de Coordenador de Geoprocessamento e uma estrutura física mínima para execução dos trabalhos. Entre 2001 e 2003 podem se destacar as seguintes ações:

- Estudo de diagnóstico das bases cartográficas existentes no Município. O estudo analisou e observou as discordâncias e deficiências de todas as bases utilizadas pela administração municipal e pelas concessionárias de serviços básicos, tanto em termos de exatidão cartográfica como de atualidade e completude. Fez uma análise crítica das tecnologias disponíveis, comparando precisão, produtividade e custos. Finalmente, a partir de uma pesquisa de mercado com as empresas de aerofotogrametria do Brasil que responderam apresentando soluções e custos estimativos, e considerando ainda os recursos disponíveis através do programa PNAFM, o documento apontou a solução a ser contratada em Aracaju.

- Obtenção e georreferenciamento de dados censitários (IBGE) da contagem populacional de 1996 e censo de 2000.

- Geocodificação do cadastro imobiliário visando à integração em SIG da planta cadastral, malha de lotes e banco de dados do cadastro imobiliário.

- $\quad$ Modelagem 3D das edificações de todas as quadras fiscais da cidade usando tecnologia CAD a partir do processamento semi-automático das plantas quadra (PQ) com o auxílio de rotinas em Autolisp.

- Apresentação de palestra no I Simpósio Regional de Geoprocessamento e Sensoriamento Remoto organizado pela EMBRAPA em 2002, mostrando um resumo dos trabalhos realizados e seus produtos.

- Apresentação de palestra no Congresso GisBrasil realizado em 


\section{Curitiba-PR em maio de 2003.}

- Participação como membro fundador da Rede Sergipe de Geotecnologias - RESGEO criada no final de 2003.

Os trabalhos foram executados com uma equipe mínima composta pelo coordenador de Geoprocessamento e um ou dois estagiários, utilizando os softwares AutoCAD e Mapinfo. A base cartográfica utilizada foi a planta cadastral da Secretaria Municipal de Finanças.

Sempre priorizando a geração de dados e informações geográficas, numa segunda etapa entre o final de 2003 e 2006 destacam-se as seguintes ações:

- $\quad$ Contratação e elaboração da nova base cartográfica de Aracaju com recursos do PNAFM. Foi contratada a empresa Engefoto que executou os seguintes serviços: em escala 1:5.000

Cobertura aerofotogramétrica dos $180 \mathrm{~km}^{2}$ do município

$\checkmark \quad$ Implantação de 52 marcos de referência planialtimétrica MR e referências de nível RN.

$\checkmark \quad$ Restituição estéreo-fotogramétrica em escala 1:1.000 de arruamento, alinhamento predial, hidrografia, prédios principais, mangues, dunas, áreas alagadiças, curvas de nível com eqüidistância de $1 \mathrm{~m}$ e pontos cotados.

$1: 1.000$

Ortofotos e ortofotocartas digitais e impressos na escala

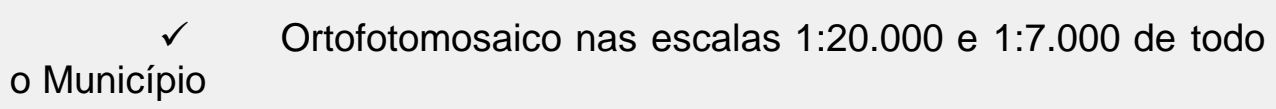

$\checkmark \quad$ Mapa Geoambiental a partir de 3 mapas base: uso do solo, carta de solos e declividade. Também foram preparados os mapas de hidrografia, legislação ambiental e áreas ocupadas/recomendadas.

$\checkmark \quad$ Mapa Municipal Oficial: mapa temático com informação de logradouros e equipamentos públicos e coletivos, editado em Corel Draw, com tiragem inicial de 3.000 unidades.

- Ajuste geométrico da malha de lotes do cadastro imobiliário sobre as ortofotocartas.

- Apresentação de palestra no II Simpósio Regional de Geoprocessamento e Sensoriamento Remoto organizado pela RESGEO, em novembro de 2004.

- Apresentação da experiência de implantação de GEO em Aracaju no Congresso GeoBrasil realizado em São Paulo-SP em julho de 2005.

- Elaboração de cartografia temática para subsidiar a revisão do Plano Diretor de Aracaju, em 2005.

- Geoprocessamento de unidades imobiliárias de áreas precárias para fins de remanejamentos e regularização fundiária.

A partir de 2006, destacam-se as seguintes ações:

- Contratação da nova planta de valores de Aracaju por inferência espacial. Trabalho realizado pelo Dr. Rubens Alves Dantas da UFPE a partir do 
cadastro georreferenciado considerando fatores microlocalizativos obtendo-se a planta espacial de valores do município.

- Constante depuração do cadastro técnico utilizando filtros automáticos e visuais em SIG aplicados sobre 0 cadastro técnico georreferenciado.

- Participação ativa nas reuniões e ações de capacitação organizadas pela RESGEO, a exemplo do Curso de Especialização em Geotecnologias organizado em parceria com a CEFET-SE que capacitou 46 alunos em duas turmas (2006-2007 e 2007-2008), sob a coordenação técnica do coordenador de Geoprocessamento da Preifeitura de Aracaju.

- Participação e apresentação da trabalho no curso internacional sobre "Impuesto a la Propriedad Imobiliária em América Latina", organizada pelo Lincoln Institute of Land Police em Santiago de Chile, abril 2007.

- $\quad$ Apresentação da palestra "Aplicações de Cadastro Imobiliário Georreferenciado na Gestão Cadastral e Urbana" no IV Simpósio Regional de Geoprocessamento e Sensoriamento Remoto organizado pela RESGEO, em outubro de 2008.

- $\quad$ Em 2008 foram contratados a atualização do mapa municipal oficial e o desenvolvimento de um sistema de disponibilização de informações geográficas via Web - SIUGWeb. Atualmente, este sistema está em fase de alimentação de dados e funcionando na rede intranet do município (RIMA), esperando-se uma melhora no link externo da Prefeitura para sua operação na Internet.

Entrevista por e_mail em 22/06/2009

\section{Questionário nº6}

Juan Carlos Gortaire Cordovez

Diretor de Gestão Urbana

Secretaria Municipal de Planejamento de Aracaju

\section{Ola Vanessa,}

Aqui vao algumas respostas. Sao incompletas mas eh o possivel neste momento. Abracos e bons estudos.

1 - Quando o projeto começou? Quanto tempo está em uso?

Primeira publicacao de produto: 1996, versão 1 do MUBDG - Mapa Urbano Basico Digital de Goiania

Sistemas estao em uso ha aproximadamente 11 anos.

2 - Quais entidades, órgãos ou secretarias envolvidas?

Comdata - Companhia de Processamento de Dados do Municipio de Goiania Seplam - Secretaria Municipal de Planejamento e Urbanismo e outras: Financas, Meio Ambiente, Educacao, Saude, orgaos de limpeza urbana e pavimentacao etc. 


\section{3 - Houve parceria com empresa privada?}

Nao. As poucas parcerias foram em geral com organizacoes sem fins lucrativos e principalmente para distribuicao de dados e aplicativos.

4 - Qual foi o histórico do trabalho com relação as bases cartográficas, banco de dados, softwares e equipe envolvida?

1994 - Firmado convenio MUBDG entre Celg, Saneago, Telegoiás e Município de Goiânia para construcao do Mapa Urbano Basico Digital de Goiania. Compilacao a partir de mapas em papel obtidos atraves de restituicao de voo aerofotogrametrico.

1996 - Publicacao da primeira versao do mapa

1997 - Criacao dos primeiros aplicativos GIS. Stand alone.

1999 - Publicado o SIGGO Visualizador de Mapas Digitais para distribuicao aa comunidade. Milhares de copias foram distribuidas para universidades, imobiliarias, radio-taxi, restaurantes, orgaos publicos e cidadaos em gral. 2002 - Rotina de geração de produtos implementada.

2003 - Ajustes pontuais na geometria do MUBDG utilizando imagem de satelite QuickBird

2005 - Acesso através da rede ao GIS

2006 - Publicada a Versão 20 do MUBDG

2007 - Ajustes na geometria do MUBDG utilizando ortofoto 1:5000

2008 - Publicada a Versão 21 do MUBDG, com PEC classe A para a escala 1:5000

2008 - SIGGO na intranet, com diversos aplicativos

Durante todos esses anos o MUBDG foi mantido por uma equipe da propria prefeitura, que foi responsavel pelo lancamento de novos loteamentos, desmembramentos, remembramentos, alteracao de nomes etc.

Software: MaxiCAD, utilizado no inicio dos trabalhos, ArcView 3.x usado para exploracao da base de dados (em uso ate hoje) e ArcGIS 9.x, usado para exploracao de dados e entrada de dados ate os dias de hoje. AutoCAD usado eventualmente para tarefas especificas.

Equipe envolvida diretamente: 6 pessoas para geracao de produtos, suporte, analises espaciais e manipulacao da base de dados.

4 pessoas para atualizacao da base de dados.

\section{5 - Qual é o objetivo principal do trabalho?}

Fornecer produtos e servicos com dados ou analises espaciais para apoiar as tarefas da prefeitura. Dentre as tarefas estao as funcoes de planejamento urbano, uso e ocupacao do solo e arrecadacao.

\section{6 - Quais são os produtos finais gerados?}

Principais produtos gerados: Mapas e relatorios contendo dados e resultados de analises espaciais. Estes produtos sao gerados pelos seguintes aplicativos:

SIGGO Uso do Solo: permite consultas as areas de restricao aeroportuaria, areas de adensamento em acelaracao e desaceleracao, hierarquia viaria, areas de preservacao permanente (ambiental), unidades de conservacao, hidrografia, limites da area urbana, areas especiais de interesse social, corredores 
exclusivos e preferenciais e outros. A maioria desses itens deve respeitar uma legislacao especifica para uso e ocupacao do solo.

SIGGO Visualizador de Mapas Digitais: permite consultas a bairros, quadras, lotes, logradouros, shoppings, rodoviarias, aeroportos, escolas etc

SIGGO Series Temporais: permite consultar acervos de imagens de Goiania de diferentes epocas.

SIGGO Parcelamentos: consultas a decretos de aprovacao, plantas originais de aprovacao e outros dados.

SIGGO Estatisticas: consultas a dados socio-economicos e outros sobre a cidade de Goiania.

Alem destes, diversos outros aplicativos geram produtos contendo dados ou analises espaciais.

7 - O SIG está disponível em site governamental? Para qual categoria de usuários: cidadãos, empresas ou governo?

O SIGGO esta disponivel na intranet da Prefeitura de Goiania para orgaos da Prefeitura.

8 - Dentre as fases de desenvolvimento do governo-eletrônico, o projeto de SIG pode-se enquadrar nas seguintes categorias:

Presença: apenas disponíveis mapas de um determinado tema, com ferramentas simples de navegação como zoom in, out, pan, etc;

Interação: Permite ao usuário fazer buscas no mapa, dentro de um conjunto de perguntas e obter respostas on-line.

Transação: Permite ao usuário pagar on-line por uma determinada carta ou tema e fazer dowload da informação que precisa. Permite realizar buscas e a construção de cartas por tema.

Transformação: Permite ao usuário a construção de cartas on -line por composição de diversos temas inclusive com operações cartográficas complexas acessando várias fontes de dados de forma integrada.

Interacao.

O usuario tem acesso as outras funcoes por outros canais.

Qual é a fase de desenvolvimento deste projeto?

Base de dados espacial: implantada, em uso e em processo continuo de atualizacao.

Base de dados alfanumerica: implantada, em uso e em processo continuo de atualizacao.

Imagens: em processo de aquisicao de atualizacao. A ultima imagem disponivel eh de 2006.

Aplicativos: diversos aplicativos desenvolvidos, implantados e em uso.

Outros em processo de construcao.

\section{9 ? Qual a previsão de evolução deste projeto de SIG?}

Mudanca de arquitetura, sem data prevista, para suportar interface browser. Inclusao continua de novos aplicativos. 
10- Há participação popular? De que forma?

Nao ha participacao sistematica da populacao. Ha a participacao de interessados de forma pontual: alunos, empresarios, associacoes de bairros e outros.

A participacao ocorre de algumas formas principais: solicitacao de dados brutos, solicitacao de servicos e mapas e indicacao de erros potenciais a serem corrigidos.

11 - Quais os benefícios para a população?

De forma direta: mais agilidade em alguns servicos (uso do solo, por exemplo), menos erros.

De forma indireta: planejamento com melhor qualidade e outros.

12 - O Governo Federal lançou em 27/11/08 o Decreto no 6.666 que institui a Infra-estrutura Nacional de Dados Espaciais (INDE), para um cadastro único nacional de banco de dados geoespaciais, a ser implantado pelo IBGE/Concar, qual é a posição deste órgão para o assunto?

Como regra geral apoiamos iniciativas de integracao, sistematizacao, padronizacao e outros esforcos que permitam potencializar as bases de dados disponiveis nas prefeituras e em outras organizacoes. 


\section{QUESTIONÁRIOS AOS MUNICÍPIOS VIA FONE OU SITE - NÃO ENVIARAM E_MAIL ANTES DO ENCERRAMENTO DA PESQUISA:}

\section{Questionário nº6}

\section{Prefeitura Municipal de \\ Teresina - PI}

Análise pelo site, sem conseguir resposta por e_mail ou telefone.

Tem o projeto Teresina Geovista, acesso através do portal municipal, elaborado pela PRODATER - Empresa de Processamento de Dados de Teresina. Disponibiliza localizador de endereços através do Google Maps e ícones para Rede de Referência Cadastral, Mapa Mercantil e Localidades de Saúde.

7 - O SIG está disponível em site governamental? Para qual categoria de usuários: cidadãos, empresas ou governo?

Sim, para cidadãos.

8 - Dentre as fases de desenvolvimento do governo-eletrônico, o projeto de SIG pode-se enquadrar nas seguintes categorias:

Presença: apenas disponíveis mapas de um determinado tema, com ferramentas simples de navegação como zoom in, out, pan, etc; Interação: Permite ao usuário fazer buscas no mapa, dentro de um conjunto de perguntas e obter respostas on-line.

Transação: Permite ao usuário pagar on -line por uma determinada carta ou tema e fazer download da informação que precisa. Permite realizar buscas e a construção de cartas por tema.

Transformação: Permite ao usuário a construção de cartas on-line por composição de diversos temas inclusive com operações cartográficas complexas acessando várias fontes de dados de forma integrada.

Qual é a fase de desenvolvimento deste projeto?

Presença

Análise do site da Prefeitura em 16/06/2009, aguardando e_mail. 


\section{Questionário nº6}

\section{Prefeitura Municipal de Salvador - BA}

Em Salvador existiu em 1998 o inicio dos trabalhos de geoprocessamento através de consultoria contratada da empresa Funcate, mas que não evoluiu. Existe o Comitê de Geoprocessamento na Congel - Cia de Governança Eletrônica de Salvador, mas ainda não se reuniram para ações efetivas.

Existe vôo aerofotogramétrico de 2006, porém a prioridade dos produtos foi para o sistema viário. Houve apenas ações embrionárias e dispersas dentro da prefeitura. Não existe qualidade dos dados geográficos, é necessário uma capacitação dos funcionários para uso com conhecimento. Acredita que com a popularização do Google Mapa, criou-se uma dificuldade de conscientização dos funcionários para trabalharem com uma base mais precisa e com mais qualidade. Existe disponível na Internet vizualizações de mapas gerados a partir do Google Mapas sobre o circuito do Carnaval, por exemplo. Acha que falta o empenho político para um direcionamento dos trabalhos de geoprocessamento. Talvez com a exigência do Ministério das Cidades sobre o CTM - Cadastro Técnico Municipal em formato digital até 2.014, venha trazer mais seriedade no tratamento dos dados geográficos.

\section{Entrevista na Prefeitura em 16/06/2009 por telefone, aguardando e_mail.}

Magda Andrade da Cogel - Cia de Governança Eletrônica de Salvador

\section{Questionário nº6}

O Projeto de SIG em Porto Alegre está caminhando, existe um banco de dados central, não são todas as secretarias que possuem software de gis, só existe em intranet, utilizam o Geolivre quando precisam de informações de cidades vizinhas.

\section{Prefeitura Municipal de Porto Alegre - RS}

Entrevista na Prefeitura em 17/06/2009 por telefone, aguardando e_mail.
Secretaria de Planejamento Municipal

\section{Questionário $n^{\circ} 06$}

O Paraná foi pioneiro na iniciativa de se criar um sistema cartográfico para o Estado, porém o projeto não evoluiu, devido a interesses políticos, segundo questionário respondido pela CELEPAR - Companhia de Informática do Paraná. O município de Curitiba foi pioneiro na implantação de geoprocessamento que teve início em 1984 . Todas as secretarias utilizam um software único, porém a maioria utiliza apenas para consultas e as secretarias de urbanismo, meio ambiente, educação, saúde e recentemente a de abastecimento fazem análise espacial. O SIG não está disponível na internet, mas pelo tempo de uso está bastante disseminado na prefeitura. Cerca de mil máquinas operam o SIG no sistema cliente-servidor. Segundo o Coordenador de Geoprocessamento do IPPUC - Instituto de Pesquisa e Planejamento Urbano de Curitiba, Oscar Schmeiske, o SIG de Curitiba já esteve em melhor fase, o modelo cliente-servidor é antigo, transaciona arquivos ao invés de dados e por isso se torna 
"pesado". Existe um projeto para que o geo esteja mais disponível à população através do IPPUC, porém ainda precisa passar por atualizações

Entrevista na Prefeitura em 06/07/2009 por telefone, aguardando e_mail.
Oscar Ricardo Macedo Schmeiske Coordenador de Geoprocessamento
Questionário nº6

\section{Prefeitura Municipal de Florianópolis - GO} desenvolvido.

Geo com várias ferramentas on-line, até com medidor de distância, bem

Acesso pelo portal municipal ou www.geofloripa.pmf.sc.gov.br

Entrevista na Prefeitura em 17/06/2009

Sr. Gilberto do GSI

por telefone, aguardando e_mail.

\section{Questionário nº6}

Prefeitura Municipal de Palmas - TO

Portal chamado SIG Palmas. Secretaria de Desenvolvimento Urbano, Meio Ambiente e Habitação.

Acesso pelo portal municipal

Entrevista na Prefeitura em 17/06/2009 por telefone, aguardando e_mail.

\section{Sra Elizabete}

\section{Questionário nº6}

A Prefeitura de Belém está bem no início do desenvolvimento do SIG. Estão fazendo um levantamento sobre as necessidades e condições atuais dos dados. Iniciando a fase de implantação, automatizando as informações. Para estes trabalhos contrataram uma empresa de Consultoria que estará desenvolvido dentro da CINBESA

Entrevista na Prefeitura em 17/06/2009 por telefone, aguardando e_mail.
Dra. Joana - Diretoria de Informações 
O projeto de SIG iniciou-se em 1999, na época contrataram um vôo aerofotogramétrico. Há 4 anos contrataram novamente para atualização da base gráfica. As principais secretarias que utilizam o SIG são Planejamento, Finanças, Educação e Secretaria de informática SEMPTI. Fora a prefeitura de Manaus, o Estado do Amazonas tem secretarias como a de Infra-Estrutura e Meio Ambiente com projetos de SIG.

Entrevista na Prefeitura em 19/06/2009 por telefone, aguardando e_mail.
Sr. Marlon - Responsável pelo Geoprocessamento 